\title{
NATIONAL MUSEUMS AND NATION-BUILDING IN EUROPE 1750-2010
}

Europe's national museums have been at the centre of on-going nation-making processes, since their creation. These museums have successfully negotiated conflicts and contradictions to obtain the support of citizens and taxpayers, domestic and foreign visitors, scientists, art connoisseurs, and policy makers. National Museums and Nation-building in Europe 1750-2010 assess the national museum as a manifestation of cultural and political desires, rather than a straightforward representation of the historical facts of a nation.

Examining the degree to which national museums have created models and representations of nations, their past, present and future, this book proceeds to assess the consequences of such attempts. Revealing how different types of nations and states - former empires, monarchies, republics, pre-modern, modern or post-imperial entities - deploy and prioritise different types of museums in their making, it constitutes the first comprehensive and comparative perspective on national museums in Europe and their intricate relationship to the making of nations and states.

Peter Aronsson is a historian and held a chair in Cultural Heritage and Uses of the Past at Linköping University. He has co-edited National Museums: New Studies from around the World (Routledge, 2011) and Performing Nordic Heritage (2013).

Gabriella Elgenius is associate professor of Sociology at the University of Gothenburg and associate member of Nuffield College and the Department of Sociology at the University of Oxford. She is the author of Symbols of Nations and Nationalism: Celebrating Nationhood (2011). 
The Eunamus programme has prepared an extensive online research facility on national museums available at www.eunamus.eu. The editors of this volume have also edited Building National Museums in Europe 1750 - 2010: European National Museums: Identity Politics, the Uses of the Past and the European Citizen, Linköping University Press (Open Access and available at: www.ep.liu.se/ecp/064/ecp064.pdf, 2011). 


\section{NATIONAL MUSEUMS AND NATION-BUILDING IN EUROPE 1750-2010}

Mobilization and legitimacy, continuity and change

Edited by Peter Aronsson and Gabriella Elgenius

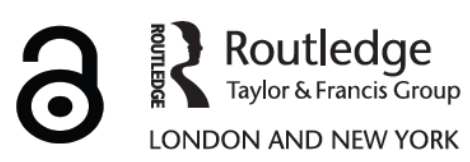


First published 2015

by Routledge

2 Park Square, Milton Park, Abingdon, Oxon OX14 4RN

and by Routledge

711 Third Avenue, New York, NY 10017

Routledge is an imprint of the Taylor \& Francis Group, an informa business

(C) 2015 Peter Aronsson and Gabriella Elgenius for selection and editorial matter; individual contributions, the contributors.

The right of Peter Aronsson and Gabriella Elgenius to be identified as the authors of the editorial material, and of the authors for their individual chapters, has been asserted in accordance with sections 77 and 78 of the Copyright, Designs and Patents Act 1988.

The Open Access version of this book, available at www.taylorfrancis.com, has been made available under a Creative Commons Attribution-Non Commercial-No Derivatives 4.0 license.

Trademark notice: Product or corporate names may be trademarks or registered trademarks, and are used only for identification and explanation without intent to infringe.

British Library Cataloguing in Publication Data

A catalogue record for this book is available from the British Library

Library of Congress Cataloging-in-Publication Data

National museums and nation-building in Europe, 1750-2010 : mobilization and legitimacy, continuity and change / edited by Peter Aronsson and Gabriella Elgenius.

pages $\mathrm{cm}$

Includes bibliographical references and index.

1. National museums-Europe-History. 2. Museums-Political aspects-EuropeHistory. 3. Museums-Social aspects-Europe-History. 4. Nationalism-EuropeHistory. 5. Political culture-Europe-History. 6. Popular culture-Europe-History. 7. Europe-Politics and government. 8. Europe-Cultural policy. I. Aronsson, Peter. II. Elgenius, Gabriella, 1967-

AM40.N38 2014

$069.094-\mathrm{dc} 23$

2014029221

ISBN: 978-0-415-85396-5 (hbk)

ISBN: 978-1-315-73713-3 (ebk)

Typeset in Bembo

by Taylor and Francis Books 


\section{CONTENTS}

List of illustrations

Introduction: making museums and nations

Peter Aronsson and Gabriella Elgenius

\section{PART I}

\section{Establishing national museums 1750-2012}

1 National museums in between nationalism, imperialism and regionalism, 1750-1914

Stefan Berger

2 Museums of civilization, museums of state, museums of identity: national museums in Europe, 1918-2000

Péter Apor

3 Museums, nations, empires, religions Tony Bennett 
vi Contents

\section{PART II}

Museum typologies: art and cultural history museums

4 The changing roles of art museums

Dominique Poulot

5 History museums and the making of citizens and communities Ilaria Porciani

\section{PART III}

\section{Conclusions and national museum analysis}

6 National museums as national symbols: a survey of strategic nation-building and identity politics; nations as symbolic regimes Gabriella Elgenius

7 National museums as cultural constitutions Peter Aronsson 


\section{ILLUSTRATIONS}

\section{Table}

6.1 Claimed origin of the first national museums in Europe.

\section{Figures}

6.1 National museums by period. 147

6.2 Timeline of first national museums. 150

6.3 Political museum map: pivotal nation-building versus national museums establishment. 


\section{CONTRIBUTORS}

The authors of this volume are reputed scholars from different disciplines such as art and cultural history, heritage studies, history, historiography, museology and sociology, and are active at universities and scholarly networks associated with highly reputed departments in Australia, Britain, France, Germany, Hungary, Italy and Sweden.

Péter Apor is a research fellow at the Institute of History, Research Center for the Humanities, Hungarian Academy of Sciences. Apor conducted research at the London School of Slavonic and East European Studies as a Fellow in Hungarian Studies (2007), the Central European University, Budapest (2003 and 2011) and at the University of Exeter (2008-9). His main research interests include the politics of history and memory, the social and cultural history of the socialist dictatorships and the history of historiography. Relevant publications include: Fabricating Authenticity in Soviet Hungary: The Afterlife of the First Hungarian Soviet Republic in the Age of State Socialism (2014) and Past for the Eyes: East European Representations of Communism in Cinema and Museums after 1989 (with Oksana Sarkisova, 2008). Apor was one of the partners of the Eunamus project.

Peter Aronsson is a historian and held a chair in Cultural Heritage and Uses of the Past at Linköping University during the Eunamus research programme (European National Museums: Identity politics, the uses of the past and the European citizen) 201013. Aronsson has developed the approach to the use of historical research as coordinator of several large-scale European and Nordic research programmes. The Eunamus programme was funded by the European Commission and set up as a collaboration of eight universities in Europe with the aim to produce the first extensive comparative analyses of the national museums in Europe. Aronsson is currently Dean of the Faculty of Art and Humanities at Linnaeus University. Among his relevant publications are Performing Nordic Heritage (with Gradén, 2013); 
National Museums: New Studies from around the World (with Knell and Amundsen, Routledge 2011); 'The productive dilemmas of history' (in Ruin and Ers, eds., Rethinking Time: Essays on History, Memory and Representation, 2011). Aronsson was the principal coordinator of the Eunamus research programme.

Tony Bennett is research professor in Social and Cultural Theory in the Centre for Cultural Research at the University of Western Sydney. He is a Fellow of the Australian Academy of the Humanities and of the UK Academy of the Social Sciences. His main publications include Formalism and Marxism (1979), Bond and Beyond: The Political Career of a Popular Hero (1987, with Janet Woollacott), Outside Literature (1991), The Birth of the Museum (1995), Culture: A Reformer's Science (1998), Pasts Beyond Memory: Evolution, Museums, Colonialism (2004), and Critical Trajectories: Culture, Society, Intellectuals (2007). He is also a co-author of Accounting for Tastes: Australian Everyday Cultures (with Mike Emmison and John Frow, 1999) and Culture, Class, Distinction (with Mike Savage, Elizabeth Silva, Alan Warde, Modesto Gayo-Cal and David Wright, 2009). Bennett was one of the scientific advisers on the Eunamus project.

Stefan Berger is professor of Social History and director of the Institute of Social Movements at the Ruhr University Bochum, where he is also chair of the executive board of the Foundation Library of the Ruhr and director of the House for the History of the Ruhr. Berger has published widely on comparative labour history, the history of social movements, nationalism and national identity studies, the history of historiography and historical theory. Berger directed the European Science Foundation Programme 'Representations of the Past: the Writing of National Histories in Europe, 1750 to the present' (2003-8) and is the general editor of the accompanying book series Writing the Nation (Palgrave Macmillan, 8 volumes, 2008-12), the general editor of the book series Writing History: Theory and Practice (Bloomsbury), History of Social Movements (Palgrave Macmillan) and two book series of the Institute (in German, with Klartext Verlag). Berger is editor of the journal Moving the Social: Journal of Social History and the History of Social Movements and Modern Europe editor of Blackwell History Compass. He is the author of the monograph Friendly Enemies: Britain and the GDR, 1949-1990 (with Norman LaPorte, Berghahn Books, 2010) and has edited the collection Popularizing National Histories (with Billie Melman and Chris Lorenz, Routledge, 2012). Berger was one of the scientific advisers on the Eunamus project.

Gabriella Elgenius is associate professor of Sociology at the University of Gothenburg and associate member of Nuffield College and the Sociology Department at the University of Oxford, where she held an award from the British Academy of Social Sciences and Humanities. She is also a member of the Centre for Migration and Diaspora Studies at SOAS at University of London. Elgenius completed her PhD as a Marie Curie Fellow at the London School of Economics and has published widely on identity politics and nation-building with particular focus on national days, national symbols and Diaspora communities. She is currently 
working on funded projects such as Diaspora Communities and Change in Britain (funded by the BA and John Fell); Are Traditional Identities in Decline? (with Anthony Heath, funded by the ESRC) and on nation-building and identity-related symbolism (Why are Some National Days more Popular than Others?), national museums and the repatriation of national heritage (funded by the European Commission). Relevant publications include: 'Politicizing apology and performing egalitarianism: the repatriation of cultural (national) heritage and human remains between the "Nordic" countries' (in prep.); Symbols of Nations and Nationalism: Celebrating Nationhood (Palgrave Macmillan, 2011); 'The politics of recognition: symbols, nation-building and rival nationalisms' (Journal of Nations \& Nationalism, 2011). Elgenius was the co-coordinator of the work package on nation- and state-building on the Eunamus project.

Ilaria Porciani is professor of Modern and Contemporary History and the History of Historiography at the University of Bologna. She has been a visiting scholar at Harvard, Berkeley, Berlin, Tübingen, Fernand Braudel Fellow at the EUI, Guest Professor at the EHESS, and a Fellow of the Italian Academy for Advanced Studies in America at Columbia University. Porciani has published widely on the history of culture, on historiography, nation-building, universities and education, with a particular focus on gender. Her book La festa della nazione was awarded the Acqui Storia Prize. Other relevant publications include Atlas of European Historiography. The Making of a Profession 1800-2005, co-edited with Lutz Raphael (Palgrave, 2010), and Setting the Standards: Institutions Networks and Communitiesof National Historiography, co-edited with JoTollebeek (Palgrave, 2013). Porciani has been the editor-in-chief of Il Mestiere di storico, the journal of the Italian society for contemporary history (SISSCO) and is a member of the editorial board of Passato e Presente and of the Journal of Modern European History. She is currently working on partitioned countries, museums and communities (1880-2015). Porciani was one of the partners of the Eunamus project.

Dominique Poulot is professor of Art History and Heritage Studies at the Sorbonne (Paris 1). He has been a visiting scholar at the EUI, at the Center for Advanced Study in the Visual Arts, at NYU, at the Getty Research Institute, and Alliance Visiting Professor at Columbia University. His main publications include Musée, Nation, Patrimoine (1997), Musées et muséologie (2005, Spanish, Brazilian, Italian and Korean translations), Histoire des musées de France (2005), Une histoire du patrimoine en Occident (2006, Brazilian translation), Patrimoine et Musée: l'institution de la culture (2014). He is also the editor of the Letters to Miranda and Canova on the Abduction of Antiquities from Rome and Athens (Getty, 2012). Relevant publications include: 'Alexandre Lenoir and the Museum of French Monuments' in Rethinking France, vol. 4 Histories and Memories (University of Chicago Press, 2010), 'Museum studies' in Art History and Visual Studies in Europe (Brill, 2012), 'Provenances and values: the recognition of Ancien Régime works of art under the French revolution' in Provenance: Transferal and Transformation (Getty, 2012) and 'The heritages of the Arab world: a perspective' in The Politics \& Practices of Cultural Heritage in the Middle East (Tauris, 2014). Poulot was one of the partners of the Eunamus project. 


\section{ACKNOWLEDGEMENTS}

The book is based on the findings of the Eunamus - European National Museums: Identity Politics, the Uses of the Past and the European Citizen - research programme, funded and supported by the European Commission during three years and eight work packages between 2010 and 2013 for the purpose of analysing significant aspects of national museums in Europe, including nation- and statebuilding, museum policy and visitor experience. The European Commission made the collaboration of eight universities possible. This programme built on a previous series of international conferences supported by Marie Curie and Namu - Making National Museums, which created an extensive network of both senior researchers and $\mathrm{PhD}$ students from around the world. The partners of Eunamus are hereby thanked and acknowledged for their enthusiasm, extensive planning and the demanding management of this exciting research programme. We are grateful to the dedication of the six partners - Arne Bugge Amundsen (University of Oslo), Alexandra Bounia (Aegean University), Constantin Iordachi (Central European University), Simon Knell (University of Leicester), Kristin Kuutma (University of Tartu), Ilaria Porciani (University of Bologna) and Dominique Poulot (University Paris 1 Sorbonne, Paris). Professors Knell, Amundsen and Bounia have been part of both projects and thus instrumental in the move from conference proceedings to a unique comparative project in the humanities. A special thanks to Bodil Axelsson (Linköping University), who was also instrumental in the process of disseminating and communicating our results, the main aim of work package eight, and for her help with the production of the extensive Open Access material. Elisabeth Weiser (Ohio State University) contributed greatly to policy briefs and summaries in the final phase of the programme. We would also like to thank Staffan Klintborg (Linnaeus University) for his help with proofreading this book. 
The management of a framework programme has depended on skilled administrators in all of the participating universities, and there are many who have contributed to this programme: The multidisciplinary research centre, Tema Q Culture and Society at Linköping University, where colleagues and $\mathrm{PhD}$ students provided a necessary and creative intellectual environment of a high standard. Svante Beckman and Johan Åkerman and his team were decisive and more than helpful with all managerial aspects that required professional support. A number of conferences have been used as testing grounds, and cooperation was facilitated by parallel projects such as Nordic Spaces and Time, Memory Representation (funded by Riksbankens Jubileumsfond) providing support and contexts for dialogue. Important input from Hans Ruin, Jens Bartelson, Viktoria Fareld and Irina Sandomirskaja has been particularly helpful. New colleagues in political science from Linnaeus University have generously shared advice - and warnings. We also acknowledge the important inspiration from participating in the programme Representations of the Past: The Writing of National Histories in Europe (NHIST) coordinated by Stefan Berger, then at Manchester University. In this context, exchange with other relevant Framework programmes must also be mentioned, such as MeLa - European Museums in an Age of Migrations - coordinated by Luca Basso Perresut. Rhiannon Mason (Newcastle University) has been a vital participant in both our projects. It is not possible to be exhaustive and fair in acknowledging all people who have contributed to the evolvement of this unique programme and thus to this conclusion. It is our hope that others will continue to make use of the great amount of material. Needless to say, shortcomings are solely the responsibility of the editors and authors.

In addition to this particular book other main publications were produced within the Eunamus programme and are listed below.

Aronsson, P. and Elgenius, G. (eds.) (2011) Building National Museums in Europe 1750-2010, Eunamus Report No 1, Linköping: Linköping University Electronic Press.

Aronsson, P., Knell, P. and Amundsen, A. (eds.) (2012) National Museums Making History in a Diverse Europe, Eunamus Report No 7, Linköping: Linköping University Electronic Press.

Bounia, A., Nikiforidou, A. Nikonanou, N. and Dicran, A. (2012) Voices from the Museum: Survey Research in Europe's National Museums, Eunamus Report No 5, Linköping: Linköping University Electronic Press.

Dodd, J., Jones, C., Sawyer, A. and Tseliou, M.-A. (eds.) (2012) Voices from the Museum: Qualitative Research Conducted in Europe's National Museums, Eunamus Report No 6, Linköping: Linköping University Electronic Press.

Eilertsen, L. and Amundsen, A.B. (eds.) (2012) Museum Policies in Europe 1990-2010: Negotiating Professional and Political Utopia [Electronic resource], Linköping: Linköping University Electronic Press.

Knell, S., Axelsson, B., Eilertsen, L., Myrivili, E., Porciani, I., Sawyer, A. and Watson, S. (2012) Crossing Borders: Connecting European Identities in Museums and Online, Eunamus Report No 2, Linköping: Linköping University Electronic Press.

Poulot, D., Bodenstein, F. and Lanzarote Guiral, J.M. (eds.) (2012a) Great Narratives of the Past [Elektronic Resource]: Traditions and Revisions in National Museums, conference proceedings from EuNaMus, European National Museums: Identity Politics, the Uses of the 
Past and the European Citizen, Paris 28 June-1 July \& 25-26 November 2011, Linköping: Linköping University Electronic Press.

Poulot, D., Guiral, J.M.L. and Bodenstein, F. (eds.) (2012b) National Museums and the Negotiation of Difficult Pasts, Eunamus Report No 8, Linköping: Linköping University Electronic Press.

Peter Aronsson and Gabriella Elgenius Sweden and Britain, May 2014 



\section{INTRODUCTION}

\section{Making museums and nations}

\section{Peter Aronsson and Gabriella Elgenius}

National Museums and Nation-building in Europe 1750-2010 is placed at the heart of the intersection where the socio-political and the scientific logics meet in the context of nation-building, representing and legitimizing nations in and through national museums. National museums and their representations have therefore within a world of nations become an international standard of nation-claiming and nation-branding. We approach the study of national museums as a historic and contemporary process of institutionalized negotiations of dominant values that constitute a basis for national communities and dynamic state formations. The national museum is thus a knowledge-based socio-political institution, with corresponding collections and displays that ultimately claim, articulate and represent dominant national values and myths. National Museums and Nationbuilding in Europe 1750-2010 will respond to basic questions about the establishment and dynamics of national museums by investigating the trajectory, context and timing of their establishment. It will also answer more complex questions. To what extent and with what consequences do the trajectory and timing of nationand state-making processes interact with museum initiatives, creations, societal challenges and justifications? Our comparative approach constitutes a first comprehensive analysis of national museums in Europe and their intricate relationship to nation- and state-making. It will highlight relevant historical developments and socio-political contexts, museum typologies, frameworks and models that provide a unique point of departure and empirical substance, shedding light on the role of national museums in the nation-building process. This volume reveals how national museums are tied to nations and deciphers their role in the nationbuilding process. Through a series of arguments, this book maps how different types of museums (based on art, archaeology, culture, history and ethnography) are deployed by different types of nations and states - empires, monarchies, republics, pre-modern, modern or post-imperial entities. National museums 
create models and representations of nations - their past, present and future - the consequences of which may also be assessed.

\section{Analysing museum- and nation-building}

The national museums of Europe have, since their creation, been at the centre of nation-making and nation-building processes. The demand for national museums followed in the wake of the Napoleonic Wars with the creation of national states, a process in which nations justified the autonomy of the state on the basis of being distinctive, unique and necessitated by historical logic. As a result, regional differences within nations were 'rearranged' to fit new modes of affiliations and loyalties that, in turn, created new forms of negotiating science, politics and social conditions. National museums have thus developed into significant institutions turning empirical evidence into consolidating perceptions of membership, ultimately related to nationhood and citizenship. The role of nations, within a system of other nations, makes some periods and contexts especially conducive to museum-building. In the contemporary world, national museums continue to engage communities sufficiently to obtain support of scientists, art connoisseurs, citizens and taxpayers, policy makers and visitors alike, and will attempt to negotiate conflicts and contradictions relating to ongoing nation-building processes. Today, one of many challenges is found in the tension between the articulation of nationalist fervour, on the one hand, and accelerating diversity and globalization on the other. National museums need therefore to be analysed as manifestations of cultural and political desires, rather than straightforward representations of historical or national 'facts'.

National values and notions of a 'Western civilization' are expressed in the national museum culture in Europe, including the values of the Enlightenment, which results in a variety of interpretations about universal, national and transnational phenomena, values, loyalties and identifications. The implications of such interpretations have taken different forms and have had different consequences depending on the formation of transnational ideas. For example, in the Scandinavian context, the cultural reconstruction of Norden (referring to Denmark, Sweden, Norway, Finland and Iceland) as a complex and collected lieux de memoire played a significant role in the production of a peaceful environment in the midst of a political climate of rival nationalisms that might have encouraged revenge and/or territorial reacquisitions. Other transnational loyalties and ambitions - of different ages - include Pan-Slavism, Scandinavianism, notions of Central Europe or of a British identity on the British Isles and have in various ways attempted to negotiate tensions with varying degrees of success. It is within such contexts, among many others, that our study of national museums - as means of representing national communalities, pride and high culture - provide us with illuminating and comparative data on processes of nationalization in Europe. In a comparative light, the trajectories of European national museums provide us with accounts of what we may call 'generalized values' of the museum-nation-state nexus and of the interactions between these entities. Exploring this nexus and its associated interactions 
facilitates an analysis of national museums as constituent components of negotiated cultural constitutions. Nations express their yearning for a proud and legitimate past and, while balancing perceived needs for continuity with a reality of challenges to this alleged unity, an agenda for facing the future is set. Some national museums are both more relevant and successful than others in meeting such challenges, with important implications for the ability to negotiate needs for integration with dynamism and change.

\section{The Eunamus research programme}

The aim of the Eunamus research programme, funded by the European Commission, was to illuminate gaps in existing research by adding a comparative perspective to the study of national museums. This book draws on such groundbreaking research conducted within several large-scale research projects. The European National Museums: Identity Politics, the Uses of the Past and the European Citizen (Eunamus 2010-13) collected empirical material of national museums in the European countries, dealing with long-time national trajectories and the negotiation of conflicts. Contemporary political utopias were thus mapped in addition to following the experience of visitors and opinions of non-visitors. All reports on the national museums in Europe were published as two Open Access volumes (www.ep.liu.se/eunamus/outcomes.html), which we hope will provide useful material for further research. This material has yielded multidimensional comparisons with this book as a first synthesized conclusion of the longitudinal interaction between national museums, nations and states. This volume will mainly use material from the Eunamus research programme and compare actors and interests that established national museum institutions on the national agenda across Europe (Aronsson and Elgenius 2011). We will take advantage of related research and publications instigated by Eunamus, such as the intricacies of grand narratives (Poulot et al. 2012a, 2012b); national museum policymaking (Eilertsen and Amundsen 2012); modes of multimodal communications museums (Knell et al. 2012) and studies of visitors' experiences assessed with the help of survey and focus groups (Bounia et al. 2012; Dodd et al. 2012). Summaries are also available for the informed public, which may provide a point of departure and a visual companion to this book (Aronsson et al. 2012).

\section{Outline}

National Museums and Nation-building in Europe 1750-2010 is divided into three analytical sections providing chronological and thematically structured presentations of our vast material: (1) the historical development of national museums in Europe from 1750 to 2012 (Stefan Berger, Péter Apor and Tony Bennett), (2) the roles played by different types of museums (Dominique Poulot and Ilaria Porciani), and (3) conclusions from the comparative analyses exploring the roles of national museums in nation-building (Gabriella Elgenius and Peter Aronsson). 


\section{Part I Establishing national museums 1750-2012}

The first analysis relates to the formative stages of national museum-building from 1750 to contemporary times up to 2012. The history of this development is linked to the pursuits of establishing empirical cultural sciences and nation-building in times of the competing loyalties and rivalling movements of regionalism, nationalism and imperialism. We commence with national museums in the long established European states and what may be called 'pre-modern' nations, followed by the analysis of the national museums in Europe's 'modern' and 'post-imperial' nations. National museums are also analysed within a framework of nations-empiresreligions, from the late eighteenth century to the present time.

Stefan Berger's chapter provides a comprehensive overview of the development of national museums in Europe between 1750 and 1914, with special emphasis on the pioneering role of new nation-states in the construction of model national museums in Europe. This chapter demonstrates how nations conducted energetic and vigorous campaigns to nationalize their newly founded states and how they became engaged in civic education with the help of their national museums. A range of thematic museums, from army to colonial museums, and from archaeological to folk museums, pursued nationalizing strategies together with heavy engagement in the geopolitical issues of borderlands. By the First World War, many European societies had been thoroughly nationalized and regions were transformed into building blocks of national discourses. Although many national museums were founded in the nineteenth century, the national discourse was one among many spatialized discourses at a time full of tensions between regionalism, nationalism and imperialism. Berger's chapter locates the development of national museums within the context of the manifold tensions produced within such spatial identity discourses and explores the growth of national museums in this first period of museum-making and concludes with a survey of the transnational elements of national museums and the processes of cultural transfer at play as they were constructed, revised, designed and reimagined.

Péter Apor's chapter analyses the transformations of national museums in Europe following the two world wars, a period marked by the dissolution of composite states and empires after 1918, the formation of new national states and identities, the establishment of socialist dictatorships, the collapse of the colonial system during the 1950s and 1960s and the Cold War. Apor's chapter addresses intersected themes, such as the reshaping of territorial-regional patterns, changes in Eastern Europe negotiating rivalling teleological universalist and communist metanarratives alongside the growth of national identities, the commemoration of victims after the Second World War, the acknowledgement of increased diversity with a resurgence of neotraditionalist ethnic identities in the 1990s, and the visualization of post-colonial and post-imperial representations. By these developments national museums were transformed into windows through which communities were represented to the world and thus moved from being sites of knowledge. Throughout the twentieth century, sensitivity to loss and guilt also developed among many elites and communities. 
Mourning the loss of human lives in the two world wars, the Holocaust, together with the loss of territory, reshaped the visual and ideological outlook of national museums and contributed to new museums being established. Nations whose prewar structures and frontiers remained intact (Britain, France and Spain) had to address the remodelled international context reflected in war and military museums, whereas the new nation-states and elites in the Baltic republics, Poland and Czechoslovakia refashioned existing museums to represent new national aspirations. Many nations had to rethink identities to reflect new or redrawn states (Germany, Hungary, Austria, Romania and Turkey).

Tony Bennett's chapter offers a synoptic account of various relational aspects between national museums, nations, empires and religions over the whole period dealt with in this book. Bennett raises significant questions about the dynamics of national museums and reinforces the arguments of transnationalism made by Berger. Bennett also explores the religious dimension, invoking secular governance, as has been recently witnessed in multi-faith policies. He notes that the relations between museums and nations have proved unstable with collections renegotiated and on the move, representing changing communities and policies. The unstable aspect of national museums applies to the restructuring of the European empires and of the relation between Europe and its former colonies. Taking Michel Foucault's general assertion of the transformation from Christian pastoral into secular governmental authority as a starting point, Bennett locates the national museum at a central point of its transformation, set in a network of other infrastructures of communication. National museums become spaces churches - for the new order of secular governance, incurring a civic economy of faults and merits. Recently we have witnessed a dramatic growth in the intensity of identifying community ties and religious belonging. This poses a challenge for museums to renegotiate their capacity to represent political community across borders. Increasing diaspora movements have lent an increasingly visible religious dimension to cultural diversity. In short, the imagined community of the nation has never completely displaced the transnational imagination of communities of different religions.

\section{Part II Museum typologies: art and cultural history museums}

A cluster of museums can be found in each nation's capital performing a concerted or contributing role under the overall label of 'national museum'. It is clear that museums of the types that have been significant for the nations in Europe reflect, in one way or other, the nation-building process. A maritime museum was vital to Portugal, whereas an ethnographic museum was deemed essential for the Slovak national movement, and, similarly, the technological museum of Munich played a role in defining German modernity. In the two chapters of the second part of this volume, two dominant museum types, the art museum and the cultural historical museum and their thematic contribution to nationhood will be analysed. 
Dominique Poulot's analysis of the changing roles of art museums provides a European typology of these. The first defining feature of the art museum is the provenance of art collections, royal or princely, ecclesiastic or private collections donated to the state. The transfer of ownership from private collectors to the state contributed to the establishment and development of the national museum tradition in Europe. Artwork related to universal ideas of beauty, as defined by the Western classic canon, gave way in the late nineteenth century to ideas of schools that celebrated the nation (and in some cases its regions). As such, art schools formed artists as well as educated citizens, and they competed with other museums and nations for the progress and success of their national culture, taste and erudition. The art museums in London, Vienna, Berlin and Paris became temples of national identity and simultaneously lent themselves to cosmopolitan trends. In this process the curators played a significant role with regard to the acquisition, display and interpretation of objects within the art museum framework. Art museums differ significantly from historical museums in their interplay with private galleries and with the market, where they feed ideas about values that are transformed into capital both culturally and financially. The significance of national art museums in the accommodation of universal ideas has generated global interest. On the one hand, post-colonial issues, international art fairs, celebrations of jubilees and other manifestations are becoming increasingly important in the marking of cultural and international relationships, while, on the other hand, aesthetic norms of contemporary art travel the globe as a rejuvenated lingua franca for cultural competition.

Ilaria Porciani's chapter addresses another museum archetype: the cultural history museum. Porciani deals with representations of the past and with how the present interacts with the representation of the past. This chapter analyses the ways in which national museums react to the drastic changes in the perception of time and the various regimes of historicity. History museums put the past on display, often shifting from a longue durée perspective to a retour de l'événement located at the crossroads of research, the production of master narratives to the popularization of public history - shifting between history and memory. Using the perspective of German Verfassungsgeschichte, Porciani explores the governance pursued by museums as zones of contact and multi-voiced and decentralized approaches as being more relevant today. Porciani's chapter, which describes the transformations of cultural history museums during the past two centuries with a particular focus on the past 25 years, comprises traditional nationalistic initiatives in Europe as well as the recent dynamic establishment of post-colonial museums in North America and Australia. It also offers an analysis of Italy and of the recreation of Italian history in honour of the 150th anniversary of the establishment of the Italian nation-state. Opposing trends are shown to be at work, including the move away from rigid understandings of the monolithic notion of national identity towards more complex approaches, interactions and cross-fertilizations. However, evidence from Eastern and Western Europe tells us that monolithic nationalism is a recurrent format of cultural historical museums that has been mobilized in today's recession-hit Europe. 


\section{Part III Conclusions and national museum analysis}

The capacity of national museums to interact with nation- and state-making is analysed in the final part of this volume. The editors of National Museums and Nation-building in Europe 1750-2010 explore national museums as national symbols and as cultural constitutions. National museums are analysed as national symbols that justify national boundaries and sustain notions of oneness by claiming through their existence that the nation is distinct from and yet on a par with other national museums (and nations). Thus, a survey of the first national museums in Europe has much to tell us about the strategic nation-building process and the role that national museums play in the politics of recognition. In the final chapter, national museums are analysed as cultural constitutions, intertwined with identity politics and nation-building. The variation in performance, it is argued, shows the plasticity of cultural institutions, some of which work more efficiently than others in complementing the more formal political constitution of each nation-state.

Gabriella Elgenius' chapter provides a novel context for the analysis of national museums as national symbols and as part of the nexus of symbolism through which nations authenticate boundaries. National symbols are often misunderstood to be decorative but represent at their core imaginations and interpretations of the nation's origin, its past, present and future. National museums are no exception and constitute therefore strategic markers of nation-and/or state-building engaged in nationbuilding at pivotal times. The inaugurations of the first national museums are of particular relevance here. With the alleged crisis of and recent debates relating to a British identity, it is noted with caution that the first national museum in Europe was the British Museum that opened in 1759, while one of the more recent museums, established by the Sami nation (Ajtte, Mountain and Sámi Museum), was inaugurated as late as 1989. To add complexity, the national museums of Serbia and Bosnia-Herzegovina have remained closed for significant periods since 1995. National museums are uniquely placed to tell us about nation-building and its imaginations and illuminate, through collections and displays, that which Anderson (1991) identified as 'imagined' or Hobsbawm an 'invented tradition' (Hobsbawm and Ranger 1992). They, moreover, highlight the crucial role of high culture in nation-building (Gellner 1983). A comparative framework is useful here and the inaugurations of the first national museum are analysed within the socio-political context and the 'politics of home' (Duyvendak 2011). Placing national museums in the context of other national symbols, often introduced with independence after the break-up of empires, makes it possible to draw attention to the strategic undertakings of nation-building, identity-politics and the patterns of symbolism with the help of the symbolic regimes approach that highlight the complexity of nations and the ongoing nature of nation-building (Elgenius 2011).

Peter Aronsson's concluding chapter analyses national museums as cultural constitutions. Aronsson argues that national museums are integral to cultural constitutions, as a more plastic but also more stable cousin of the rather rigid political constitution. Their general historical context is understood in terms of cultural 
negotiations feeding the argument that national museums constitute a central component of the cultural constitution that helps to inform and shape the political constitution. This chapter places the argument in between a narrow critical account of the power of the museum as a formal heritage institution, at the one end, and the apologetic defence of the institution at the other. In terms of a conceptual framing, cultural constitutions are constructed by the proximity to, difference from and interaction with the constructions of political constitutions. This chapter assesses the actual role of European museums and highlights the formative moments in museum history. National museums vary in the degree in which they contribute actively to the formation of nation-states, help stabilize policymaking by negotiating dilemmas and conflicts or fail to play an instrumental role due to incapacity. Two major ideal types of national museum representations can be identified: the Symphony and the open Concert Hall. The relative success is not, however, related to the format, but rather to the relevance and interaction made possible in relation to contemporary challenges through the cultural constitution. Three impact scenarios towards well-functioning cultural institutions and contexts in which national museums have the potential of contributing substantially through their legitimacy and negotiating capacity are as follows: (1) promoting cultures of tolerance, creativity and integration, (2) promoting higher levels of trust between civil society and state or (3) negotiating a negative impact with the failure of the cultural constitution that would lead to the failure of the state.

\section{References}

Anderson, B. (1991) Imagined Communities: Reflections on the Origin and Spread of Nationalism, London: Verso.

Aronsson, P. and Elgenius, G. (eds.) (2011) Building National Museums in Europe 1750-2010, Eunamus Report No 1, Linköping: Linköping University Electronic Press.

Aronsson, P., Knell, P. and Amundsen, A. (eds.) (2012) National Museums Making History in a Diverse Europe, Eunamus Report No 7, Linköping: Linköping University Electronic Press.

Bounia, A., Nikiforidou, A. Nikonanou, N. and Dicran, A. (2012) Voices from the Museum: Survey Research in Europe's National Museums, Eunamus Report No 5, Linköping: Linköping University Electronic Press.

Dodd, J., Jones, C., Sawyer, A. and Tseliou, M.-A. (eds.) (2012) Voices from the Museum: Qualitative Research Conducted in Europe's National Museums, Eunamus Report No 6, Linköping: Linköping University Electronic Press.

Duyvendak, J.W. (2011) The Politics of Home: Nostalgia and Belonging in Western Europe and the United States, Basingstoke: Palgrave Macmillan.

Eilertsen, L. and Amundsen, A.B. (eds.) (2012) Museum Policies in Europe 1990-2010: Negotiating Professional and Political Utopia [Electronic resource], Linköping: Linköping University Electronic Press.

Elgenius, G. (2011) Symbols of Nations and Nationalism: Celebrating Nationhood. Basingstoke: Palgrave Macmillan.

Gellner, E. (1983) Nations and Nationalism, Ithaca, NY: Cornell University Press.

Hobsbawm, E.J. and Ranger, T.O. (1992) The Invention of Tradition, Cambridge: Cambridge University Press. 
Knell, S., Axelsson, B., Eilertsen, L., Myrivili, E., Porciani, I., Sawyer, A. and Watson, S. (2012) Crossing Borders: Connecting European Identities in Museums and Online, Eunamus Report No 2, Linköping: Linköping University Electronic Press.

Poulot, D., Bodenstein, F. and Lanzarote Guiral, J.M. (eds.) (2012a) Great Narratives of the Past [Elektronic Resource]: Traditions and Revisions in National Museums, conference proceedings from EuNaMus, European National Museums: Identity Politics, the Uses of the Past and the European Citizen, Paris 28 June-1 July \& 25-26 November 2011, Linköping: Linköping University Electronic Press.

Poulot, D., Guiral, J.M.L. and Bodenstein, F. (eds.) (2012b) National Museums and the Negotiation of Difficult Pasts, Eunamus Report No 8, Linköping: Linköping University Electronic Press. 

PART I

Establishing national museums

1750-2012 



\title{
1
}

\section{NATIONAL MUSEUMS IN BETWEEN NATIONALISM, IMPERIALISM AND REGIONALISM, 1750-1914}

\author{
Stefan Berger
}

\section{Introduction}

When visiting the National Museum of Finland in the summer of 2007 the author of these lines came across a text right at the start of the exhibition that read: 'After the Ice Age the first known human settlers arrived in Finland around 10,000 years ago. These people hardly differed from present-day Finns in their physical and mental capacities.' While this can be read as a subtle self-criticism of the faculties of present-day Finns, it is more likely an example of the desire of national master narratives (Thijs 2008) to protract a national storyline into the dim and distant past. The further the national history can be traced into the past, the more distinguished the present-day nation is. This was one of the most cherished principles of nineteenth-century national museums and it is one that has not entirely died out in contemporary national museums, as the Finnish example demonstrates.

This chapter provides an overview of the rise of the national museum in Europe from the middle of the eighteenth century to the outbreak of the First World War. It will start off with a discussion about what types of national museums could be found and what characterised them in the long nineteenth century. Thereafter, the pioneering role of new nation-states in the construction of model national museums is analysed with a variety of examples from all parts of Europe. However, as Jürgen Osterhammel (2009) has pointed out, the long nineteenth century was much more a century of empires than a century of nation-states. However, if we look at the national museums of Europe, we can see how any dichotomous construction of national vs. imperial fails to capture the complex interplay of the imperial and the national in many regions of Europe. The imperial was not only present in many national museums; it was often a constitutive element, indicating to what extent nation-building took place within empires - both at the core and in the peripheries (Berger and Miller 2015). Stateless nations in the nineteenth 
century could, above all, be found in those peripheries of empire, and the chapter takes a closer look at the way in which museums in those regions depicted the topic of the nation. This leads to a discussion of representations of regionalism in national museums: when does a region become a nation? And to what extent do national storylines rely on regional building blocks? The interrelationship between region and nation is just as intricate as that between nation and empire (Augusteijn and Storm 2012), and the chapter overall demonstrates that the different spatial levels of identity-formation are all present in European national museums during the long nineteenth century, with culture, history and national politics powerfully intersecting. The chapter concludes with a survey of the transnational elements of national museums: what processes of cultural transfer were in play when they were constructed, revised, reimagined and newly designed. Where did the actors involved in the making of these museums look in order to realize their ambitions? In the final section of the article the question is raised to what extent the national museum was an all-European phenomenon with discernible patterns both in the material and in the idealistic construction of buildings and narratives.

\section{Types of national museums}

In many places, archaeological museums were the archetypal national museums of the nineteenth century, which had much to do with the desire to trace the national heritage as far back as possible. In Denmark, for example, the Nordic Ancient Museum was founded in 1819. As early as 1806 the Danish antiquarian Rasmus Nyerup summed up the ambitions of all nineteenth-century national antiquity museums succinctly as being 'an asylum for slowly disappearing ancient national monuments ... a temple for the remains of the spirit, language, art and power of our past, where every patriot can study the successive advances of the nation's culture and customs' (cited in Bligaard 2000: 288).

The fascination with national ruins was most obvious in the 'ancient' nations of Greece and Italy. In Greece, for example, key national museums, such as the National Archaeological Museum, the Byzantine and Christian Museum, the Museum of Greek Folk Culture and the National Historical Museum, have had the key task of guaranteeing the continuity of the ancient Greek splendours to the present day. From early on, Byzantium was regarded as an important link between the distant past of ancient Greece and the national revival in the nineteenth century. In Italy, ruins of classical Rome were used to celebrate a sense of Romanità both in Italy itself, and in the North African colonies, where archaeological sites were always seen as symbols of the imperial mission of the contemporary Italian state (Canadelli et al. 2011; Gazi 2011; Trümpler 2008).

However, the link between antiquities/archaeology and the search for a usable national past in the present was not restricted to those nations that could lay claim to a heritage rooted in the ancient cultures of Greek city states and Rome. Thus, for example, the origins of the Germanic national museum in Nuremberg lay in Hans von Aufseß's enthusiasm for collecting national antiquities from the 1820 s 
onwards. Whilst Aufseß looked backwards to an ordered estates-based medieval nation, other antiquarians linked their enthusiasm for an ancient Germanic past with their desire for a modern German nation-state. The Nuremberg Museum, when it was founded in 1852, was most certainly a political statement seeking to popularize the national idea in the German lands (Crane 2000; Wolbring 2009).

In France, the Musée des Monuments Français opened its doors in Paris in 1801. Established by Alexandre Lenoir to house the many statues from the palaces of the aristocracy and the church that were plundered and ransacked during the revolution, it was closed again after the restoration in 1816. However, it was to set the tone for national antiquities museums in France throughout the nineteenth century. Thus the state bought a huge private collection of antiquities established at the medieval Hotel de Cluny in Paris in 1843 and transformed it into a national museum of antiquities (Stara 2012).

Antiquarian and learned as well as scientific societies and the nascent academic disciplines at emerging research universities (Clark 2006) played an important role in the setting up of archaeological museums. A mixture of erudition and patriotic sentiment motivated its members to seek alliances, often with states or with powerful aristocratic and monarchical circles - after all, many of the early learned societies had a high percentage of aristocrats among their members (Clemens 2012) - in order to build up collections and found museums.

Archaeological museums were often supplemented by history museums. The stronger materiality of the former, i.e., the exhibition of the physical remains of the distant past, gave them an advantage over the latter, which had to operate more with copies, illustrations or texts. Nevertheless, the growing popularity of national history museums in nineteenth-century Europe was a sign that history held a prominent place in the construction of national master narratives (Porciani 2012; Berger with Conrad 2015). In some respects, history museums worked as extensions of archaeological museums as they traced the national story into the more recent past. One of the earliest and best examples of such a national history museum is the one still in existence in Budapest today. It was founded in 1802, when Count Széchényi donated his extensive library and collection of antiquities to the public. It moved to the site it inhabits today in 1846. The neo-classical design of the building was supposed to underline the nobility of the Hungarian nation. On its steps, the poet Sándor Petófi declared the 1848 Hungarian revolution and, during the late nineteenth century, the upper house of the Hungarian parliament held its sessions at the museum. The patriotic depiction of the country's national history has been very much at the heart of the museum, which also played an important role in shaping the Hungarian national master narrative.

Folk history museums were a special type of national history museum founded from the late nineteenth century onwards. They were important in defining the social and ethnic in- and out-groups of the nation. They invariably preferred the rural, agricultural peasant traditions of the nation over the industrial, urban- and middle- as well as working-class representations. Especially in countries with a strong peasant tradition, folk museums played a very important part in presenting the 
national storyline. One of the earliest open-air folk museums was Skansen in Stockholm, founded in 1891, which represented a 'unity in diversity' narrative that justified the Swedish union with Norway. Interestingly, from the very beginning Skansen included a representation of the Samis, who were, in other contexts, excluded from Nordic national history until well into the twentieth century. ${ }^{1}$ Folk history museums operated as historical theme parks representing what was particular about the nation's architecture and landscape. They thus stand in a tradition of landscape gardening going back to the eighteenth century. Given that there was invariably an emphasis on ancient architectural forms, most folk museums had a Romantic and nostalgic outlook onto the national past (Dewhurst and MacDowell 1981).

For archaeological, historical and folk museums, the demonstration of continuity was key. The narratives emerging in these places were invariably those describing continuity, or explaining discontinuity and finding ways of bridging periods of discontinuity, as confirmed discontinuity was unacceptable in the national master narratives of nineteenth-century Europe (Berger et al. 2008-15). Furthermore, the narratives contained in these museums described continuous civilizational progress, in which the nation played a prominent part (Jennings 1991: 94-6).

Art museums were, without any doubt, the most prominent and spectacular national museums in the nineteenth century. The great masterpieces of the past seemed to speak of national genius and often also depicted scenes of great national importance. Art was widely seen as an educator and edifier of national citizens. It is not by coincidence that the emerging discipline of art history classified art along national lines in the nineteenth century: French, German, Flemish, Italian and Spanish schools, etc. Nationalized art was supposed to reflect national character. Its public display was to demonstrate the greatness of one's own nation against others. It is not by coincidence that collections often differentiated between 'national art' and 'other art'.2

National museums containing collections that originated in empire and imperial expansion were also prominent in nineteenth-century Europe. The most important example here was the British Museum in London. Its origins, not unlike those of the Hungarian National Museum, can be traced to a personal bequest. Sir Hans Sloane gave his entire collection of more than 70,000 objects to the nation via King George III. As a direct result, the museum was founded by an Act of Parliament in 1753. In the course of the nineteenth century, it received, through British imperialism, a steady flow of valuable acquisitions, including the Rosetta Stone (1802) and the Parthenon sculptures (1816). During the same century, it built up strong Assyrian and Egyptian collections. The visitor was left in no doubt when he sampled its global treasure trove that it was due to Britain's domination over the world that all the treasures had ended up there. In other words, the museum was one way of celebrating the achievements of empire (Caygill 1981; Caygill and Date 1999).

Similar imperial-national museums were created in many European capitals, in particular those with colonial and imperial ambitions. It is interesting how many of these collections not only demonstrated imperial power by showcasing the cultures 
of the world in the European metropolis, but also claimed particular heritages of high civilizations. Moving Roman and Greek temples to London, Paris and Berlin and displaying them there sent out messages that the nineteenth-century European empires claimed the mantle of the ancient European empires and civilizations. It is not by coincidence that the architects of the British Empire time and again depicted themselves as heirs to the Roman Empire and saw their own virtues related to those that had fired the latter. The architectural designs of the landed estates of the British high aristocracy mirrored this historical self-understanding of an imperial elite closely (Butler 2012). Germans, perhaps for lack of real imperial power, liked to portray themselves as heirs to the ancient Greeks in their endeavour to be the spearhead of the nineteenth-century scientific revolution and humanist scholarship (Quack-Eustathiades 1984).

The formation of nations in nineteenth-century Europe was closely related not only to empire but also to war. Hence it is not surprising that military collections played a major role as national museums - often depicting national struggles for liberation or military victories that secured national independence or otherwise spelt glory and power for the nation. Thus, for example, the military storehouse, established in 1839 in Istanbul, was an important precursor to the Turkish Military Museum of the twentieth century. With its mixture of weapons, armoury, religious relics, all captured in various wars of the Ottoman Empire, it was an important imperial museum but it could be accommodated in its message to the Turkish nationalism espoused by the Young Turks in the early twentieth century (Shaw 2003).

Technical museums as national museums were particularly prominent in those nations defining themselves through scientific progress and portraying themselves as the epitome of modernity. The Deutsche Museum in Munich, for example, was founded in 1903 at a meeting of the Association of German Engineers - the one social group that chose this way of depicting its special value for and contribution to the making of a great nation. At the beginning of the twentieth century, the German Reich looked back to an unprecedented industrial sprint during the previous half century, which resulted in Germany overtaking Great Britain as first industrial nation in Europe on the eve of the outbreak of the First World War. The museum underlined such national achievement (Alexander 1983; Mayr 1990). In other parts of Europe, industrial and technical museums were also meant to encourage and develop the industrial potential of the nation. Thus, the Museo Industriale Italiano, founded in Torino in 1862, or the Museo Artistico Industriale, established in Rome in 1873, were not so much statements of existing achievements than expressions of intent. It was perhaps indicative of the shortcomings of Italy's economic performance that both failed to establish themselves and were in decline long before the nineteenth century came to an end (Amari 2001).

Landscapes were vital for the national imagination in the nineteenth century (Lekan 2009; Williams and Smith 1983; Daniels 1993). Hence we find a great number of natural history museums among the nineteenth-century national ones. They invariably sought to nationalize landscapes and natural history more 
generally. The British Museum's collections included natural history until the 1880s, after which they were moved to a separate Natural History Museum in Kensington. The nature displayed in such museums was never natural. Instead, flora, fauna, mountains, lakes, seaside and other landscapes were shaped in their description and portrayal by the national imagination of the middle and upper classes of the respective European societies (Köstering 2005). Natural history museums shared with their history counterparts the claim that their displays were based on 'science'. In the nineteenth century, the claims of science did not only transform the world, they also achieved an unrivalled authority in which they could speak, also on behalf of the nation, in and through museum landscapes, whether their concerns were natural or human history. Museums interpreted objects scientifically and presented narratives validated by science. By doing this they themselves claimed authority over the stories contained in their exhibitions (Conn 2011).

Last but not least, it is important to note that the national was present in a great many 'specialist' museums. Labour museums, museums of particular industries or crafts or food museums all picked up the national theme, especially where their objects were related to specific national self-images.

\section{New nation-states and national museums}

Flora Kaplan has pointed out that 'museums have long served to house a national heritage, thereby creating a national identity and often fulfilled national ambitions' (Kaplan 1994: 1). Peter Aronsson has underlined that the shape of national museums has been influenced by the chronology and the specific set-up of the nation-state in Europe (Aronsson 2011). Similarly, Tony Bennett (2006), using Foucauldian frames, has analysed the museum as an institution that became part and parcel of the way in which governmentality operated from the last third of the nineteenth century onwards. Hence it is only logical that new governments of new nation-states, such as Belgium, Norway, Germany, Italy and Greece were far more likely to develop national museums than nation-states that had developed more gradually since the Middle Ages. Thus, for example, the Hungarian National Museum, already referred to above, was founded as early as 1802, but it arguably came fully into its own as promoter of the national cause only after the agreement with the Habsburg Empire to grant greater autonomy to a Hungarian sub-empire with the so-called Ausgleich of 1867 (Apor 2011). Most of the national museums of Finland, such as the Finnish National Gallery, the National Museum of Finland and the Natural History Museum, were in fact established before the country's independence in 1917, but after it had left Sweden and established a Grand Duchy within the Russian Empire in 1814. The Grand Duchy heavily subsidized civic attempts to construct national collections around the middle of the nineteenth century (Pettersson 2011).

Belgium, in fact, opened its first national museum only five years after the nation-state had been founded in 1835 . The formation of such museums, which 
culminated in the creation of the Musées Royaux d'Art et d'Histoire, was explicitly related to the strengthening of national pride (Tollebeek 1998). When Bulgaria gained its independence from the Ottoman Empire in 1878 it also almost immediately initiated a range of measures intended to highlight the national past in an attempt to bolster national sentiment. It was invariably anti-Ottoman and underlined the five centuries of alleged struggle for national independence. However, like in Belgium, the foundation of national museums and memorials was massively supported not only by the state but by diverse agencies of civil society. Thus, for example, it was a civic initiative that led to the foundation of the Naroden Muzei (People's Museum) in Sofia in 1905 - an idea that can be traced to meetings of the Bulgarian Learned Society as far back as the 1840s. Such examples serve as cautionary tales warning against underestimating the role of civil society in the creation and development of national museums. It often worked hand-in-hand with institutions of the state in supporting such nationalizing institutions (Vukov 2011). In Germany, for example, the Kaiser Friedrich-Museums-Verein, founded in Berlin in 1896, and the Städelsches Museums-Verein, founded in Frankfurt in 1899, are two examples of civic associations, in which the wealthy came together to support such institutions (Aronsson and Bentz 2011).

While museums, some of which calling themselves 'national', existed in the German lands well before the foundation of a German nation-state in 1871, they were often characterized by a certain ambiguity about which nation they were seeking to represent. Arguably, in the bigger German states, especially Bavaria but also Prussia, an active promotion of Bavarian and Prussian national sentiment overlapped and interrelated with German national sentiment in complex ways that still need to be fully explored. It was only after the defeat of Bavaria (which had sided with Austria) in 1866 that the Bavarian National Museum in Munich toned down its Bavarian national appeal and fashioned itself in more professional and less overtly political tones (Glaser 1992). Many museums of the individual German states that had been founded before 1871 in fact started to regionalize their missions after the foundation of Imperial Germany and sought to combine a regional with a national all-German appeal. After 1871 it is a different story: massive state funding, together with strong civic engagement, led to a veritable explosion of foundations of museums, many of them explicitly national in their ambitions. The beginning of the twentieth century especially saw a veritable museum boom in Imperial Germany, with 210 new ones being founded between 1900 and 1920 (Hein 2009: 155). In Berlin the 'museum island' (Museumsinsel) is a good example of the way in which these were promoted in the new national capital of Imperial Germany. The old national gallery (Alte Nationalgalerie) was erected in an architecturally pompous style to underline the new-found ambitions of the new nation-state. Its inscription over the entrance states a dedication: 'To German Art, 1871' ('Der deutschen Kunst, MDCCCLXXI'), which could not be clearer in its nationalizing message. Before the entrance, statues of Frederick Wilhelm IV and of Germania as patron saint of the arts were positioned, and Emperor Wilhelm I and his wife found a place in the entrance hall of the museum (Forster-Hahn 1994). 
In some respects the other classical case of unification nationalism, Italy, represents the perfect counterexample to the German one. Here the dearth of financial resources in the new-found Italian nation-state prevented any large-scale funding of national museum projects. Instead, the Italian state simply took over what already existed in terms of a rich landscape of museums, renaming some, like the Museo Borbonico in Naples into 'Musei Nazionali' (De Caro 2003). This superficial upgrading left the country with a host of national museums that did not really present or develop a national master narrative. Instead, they often undermined it by clinging to older regional narratives that stood in the way of successful Italian nation-building.

Personal initiative was all the more important where the new-founded nationstate lacked financial muscle. The National Museum of Antiquities was established by the Romanian state in Bucharest in 1864. However, the Romanian national museum also had its origins in a private collection, namely that of the Boyar Mihalache Ghica, who opened it to the public as the Natural History and Antiquities Museum in 1834. Patriotic motives featured prominently in his decision. After all, the Wallachian uprising of 1821 had witnessed the emergence of national sentiment in the region. Furthermore, Ghica was the brother of the ruler of Walachia at the time, which made his initiative a quasi-state one, and it was certainly welcomed by the authorities in Walachia who wanted to promote Romanianness. It became known as a national museum as early as the 1830s. The failed national revolution of 1848 and the subsequent struggle against the Ottoman Empire finally led to independence in 1878 and to the establishment of a kingdom of Romania in 1881. Like the British Museum, the museum founded by Ghica was divided into a Natural History Museum and an Antiquities Museum in 1864. The latter was hosted by Bucharest University before being housed in its own building and explicitly reconstituted as the Romanian National Museum in 1906. The creation of the Romanian state after 1881 was an important boost behind the firm foundation of the national museum in the early twentieth century, although it could not have been built without private benefactors (Bădică 2011).

In the nineteenth century, national museums often sought to represent the monarchical nation. This is not really surprising, given that many collections before the nineteenth century originated in royal or aristocratic galleries and cabinets that were first opened cautiously to the public and were then in many cases transformed into national collections, sometimes, where appropriate, retaining the epithet 'royal'. Royal and national thus morphed into each other and became almost indistinguishable. Many European monarchies had, after all, caught onto the power of liberal nationalism and sought to harness nationalism for their form of government. Monarchical nationalism was a strong feature of post-mid-nineteenth-century Europe (Berger and Conrad 2014: Chapter 4). By making the nation and the dynasty into one, dynastic rule was strengthened, or such was at least the vision behind monarchical nationalism. The Alte Nationalgalerie in Berlin, for example, was inaugurated in 1876 on the birthday of Wilhelm I (Aronsson and Bentz 2011). Still, monarchical nationalism never was the only show in town. In fact, the 
interrelationship of the museum with national narratives was a varied and manifold one (Carbonell 2012: 82-91).

\section{National museums and questions of empire}

The British Museum, as discussed above, was undoubtedly the foremost example in nineteenth-century Europe of a national museum functioning as an imperial one. Similar national-imperial museums could be found in all of the nineteenth-century European empires. Napoleon III was to present to the French nation an archaeological museum, the Musée de St. Germain-en-Laye, which was to emphasize the imperial Roman roots of France. The emperor had, after all, written - with a little help from noted contemporary antiquarians - a biography of Julius Caesar. GalloRoman and Celtic antiquities became the foundation stone for the new French Empire. A line of continuity from the old Roman to the new French Empire could thus be drawn. In fact the first mission statement of the museum from 1866 emphasized its imperial aspect, its aim being described as 'to centralize all documents pertaining to the history of the different races that have occupied the territory of the Gallic empire from the most far off times up until the era of Charlemagne' (cited on the museum's website: www.musee-archeologienationale. fr/template.php?MENU_ID=2\&SUBMENU_ID = 1; accessed 14 March 2014).

The Louvre, which became known as the Musée Napoléon in 1803, became an imperial museum already during the Napoleonic era, as it housed the many war trophies that Napoleonic imperial expansionism in Europe brought to the museum up to 1816. Not unlike the British Museum, it housed the art of the world as a means to display French imperial ambitions throughout the nineteenth century (Poulot 1992; McClellan 1994; Bodenstein 2011a). In fact, the origins of the national museum in Europe lie in the Napoleonic era and its imperial expansionist project. The empire's promotion of the French nation triggered counter-promotions among all those who felt threatened by that empire (Bergveldt et al. 2009).

The themes of military expansion and colonialism were not only strong among the long-established empires. Some of the new imperial nations of the nineteenth century were keen to display their new-found imperial missions. Thus, for example, the Musée Royal de l'Afrique Centrale, founded in Tervuren, and the Musée Royal de l'Armée, which both opened their doors in Tervuren and Brussels in 1910, proudly exhibited the colonial and military prowess of the young Belgian nationstate. King Leopold II who, between 1885 and 1908, ruled the Congo as his personal colony, was instrumental in establishing the Musée Royal de l'Afrique Centrale, seeing this as an opportunity for the 'colonial education' of the Belgian people, bringing the colonial vocation of Belgium closer to them. Yet by the time the museum opened its gates to the public in 1910, the Congo had been formally annexed by Belgium and made into a Belgian colony rather than a royal one - after considerable criticism of the brutal way in which Leopold had run his personal colony. Hence the Musée du Congo Belge, as it was known at the time, presented to its visitors the economic benefits of the colony to Belgium as well as the moral 
and physical progress of the indigenous population under Belgian rule (Cornelis 2000). The military museum of Belgium was also established in 1910. It originated in the personal collection of more than 900 military items by a Belgian officer, first displayed in the Universal Exposition of 1900. Out of this grew the plan for a more permanent museum that would display the military prowess of the young nation that had not only laid the groundwork for its independence but also for its status as a European colonial power in the early twentieth century (Lorrette 1965).

Within imperial borders we also find many regional museums that tended to celebrate the regional diversity of empires just as they often portrayed a storyline that highlighted the role of the region as building block of the nation. The Austrian emperor travelled his realm and changed his costumes from region to region, thereby indicating a similar narrative, according to which the empire consisted of its distinct regions in which much identity was invested, while the Habsburg emperors were representative of them all (Telesko 2006). Prominent Landesmuseen were founded in 1811 in Graz/Styria (Joanneum), in Innsbruck/Tyrol in 1823, in Linz/Upper Austria in 1833 and in Klagenfurt/Carynthia in 1844. It is not a coincidence that the earliest Landesmuseen could be found in Germanspeaking parts of the Austrian Empire, as the dominance of its German speakers was a striking feature to the very end. However, after 1866 the Habsburg Empire was in a unique position among European empires in that it could not nationalize its core, as this task was taken over by Prussia in the North (Komlosy 2015). Even the Ottoman Empire nationalized itself, albeit very late, around a Turkish core (Eisenstadt 2015).

Only the Habsburg Empire went along a special path in that it kept to the idea of sub-national entities finding their unity in the imperial state structures. The two main imperial museums at the grand Ringstrasse in Vienna, the Art History Museum and the Natural History Museum, were certainly designed to the greater glory of the empire, showcasing collections that were to demonstrate to the viewers its powers and glories - without, however, carrying a nationalizing message, which was so often contained in other imperial museums (Kriller 2000). Similarly, the Army Museum (Heeresgeschichtliches Museum), planned since 1848 but inaugurated only in 1891, was in essence a history museum underlining the proud history of the House of Habsburg and the empire. Statues of prominent rulers and commanders, war paintings from its various wars throughout the centuries and a statue of Austria, symbolizing the empire, all underlined the imperial message of the museum (Rauchensteiner 1997). However, when the non-German speakers in the Habsburg Empire also started to build their museums, they often occupied a hybrid position between regional and national museums. After 1867 the Austrian Empire contained, within its borders, a Hungarian sub-empire, which vociferously nationalized its core. The Hungarian National Museum, discussed above, is an excellent example of such a discursive construction of an imperial nation.

Declining empires in nineteenth-century Europe did not find an appropriate way of exhibiting their status in national museums. If we take the example of Portugal, imperial collections remained to a large extent in the possession of 
individual families. They were not strongly represented in national museums, where the colonial and imperial theme was only 'discovered' and celebrated under the twentieth-century dictatorship of Salazar (Bodenstein 2011b). In the Netherlands, the colonial and imperial history was widely neglected in national museums during the nineteenth century (Bergveldt 2012). In Spain, the collections that Philip II had assembled in El Escorial in the second half of the sixteenth century befitted what was, after all, the largest empire of the world at the time. The Cabinet of Natural History, which was established in Madrid in 1771, contained many specimens from the Americas and the Pacific, again underlining the imperial nature of the Spanish state and crown. Even when Spain was still clinging onto the remnants of a once great empire in the late nineteenth century, it promoted its colonial legacy through museums. Thus, for example, the Spanish state founded the Museum-Library of the Overseas in 1887 following a very successful exposition of the development of the Philippines under Spanish rule. In 1892 another major exhibition was staged, commemorating the discovery of the new world by Christopher Columbus in 1492. It celebrated and underlined Spain's colonial mission in the world. When, in 1899, Cuba declared its independence and the Philippines became a colony of the USA, the response of the Spanish state was to close the Museum-Library of the Overseas. It was a highly symbolical measure, for after 1899 the Spanish state hesitated to promote colonialism and imperialism, which also meant that the imperial messages of national museums were not very prominent as the long nineteenth-century drew to a close (Kamen 2008; Lanzarote and María 2011).

\section{Stateless nations and national museums}

Many nineteenth-century nations were in search of statehood. Establishing national museums was for them a marker of their ambitions. We have above already referred to Romania and the role of its nascent national museum in underlining Romanian ambitions for nation-statehood in its struggle against the Ottoman Empire. Similar examples can be found in many parts of nineteenth-century Europe. Given that it was often intellectuals and professors who were among the most ardent supporters of the national idea, it cannot be surprising to find a strong link between early efforts to set up national museums and universities. We have found such a link with the University of Bucharest in Romania and we have a similar link between early national museums and the University of Oslo in Norway, established in 1811. Important collections of Norwegian antiquities and ethnology were housed and exhibited in the university during the nineteenth century. In Norway's case, the ending of the link with Denmark and the creation of the personal union with Sweden in 1814 provided many opportunities for nation-building, as it gave to Norway its own parliament and much administrative autonomy. Thus, for example, the National Gallery in Norway was established by an act of parliament in 1836. The decision that was taken around 1850 to concentrate more on the collection of national art than on presenting international art 
to a Norwegian public can be related to the nascent desire to put Norway on the map of European art. Private initiatives of nationally minded citizens augmented the initiatives by state institutions. Thus, both the Norwegian Folk Museum (established in 1894) and the Museum of Decorative Arts and Design (established in 1876 as Kunstindustrimuseet) in Oslo were private initiatives that aimed at establishing the specific value and authenticity of Norwegian cultural life as well as Norwegian arts and crafts in comparison with those of other European nationstates, thus seeking to put Norway's artistic achievements on a par with those of existing European nation-states (Amundsen 2011).

However, we also find nations that were not looking for statehood and were still establishing national museums as markers of cultural distinction. One such case was the National Museum of Wales, which was founded in Cardiff in 1907 by members of the city's civic leadership and individuals from within the learned societies of the city. Since Victorian times, this civic elite had displayed an ever-growing interest in the distinctive cultural and historical features of Wales. The strength of non-conformism in the country underlined the religious differences to Anglican England and furthered the perception of cultural difference. The Cambrian Archaeological Association, established in 1846, argued for the preservation of Welsh antiquities and the setting up of museums as early as 1847. By that time a natural history museum, founded in Swansea in 1821, and a museum of the Royal Institution of South Wales, founded in 1841, already existed. Other learned societies, such as the Royal Cambrian Society and the Honourable Society of Cymmodorion were also in the vanguard of those calling for Welsh museums.

Many other nineteenth-century museums in Europe had their origins in civic pride, but in Wales a form of cultural nationalism was a distinctly added ingredient. From the 1880 s onwards Welsh MPs began to raise the issue of national institutions, including a national museum. The derision with which such calls were greeted in England only tended to strengthen national sentiments in Wales, as did the infamous 'blue books'. A government commission charged with looking at the state of education concluded that the use of the Welsh language had a detrimental effect on the education system in Wales and published this opinion in a report (blue book). It caused an uproar by openly talking about the 'backwardness' and 'laziness' of the Welsh and furthered the determination to establish cultural institutions that would serve as a defence against what was perceived as English condescension vis-à-vis Welsh culture. The foundation of the National Museum of Wales in Cardiff in 1907 was driven by various factors, including civic pride, a rivalry between different Welsh cities but also this very desire to establish a cultural distinctiveness within the British Isles. Thus, from the outset it chose a title, Amgueddfa Genedlaethol Cymru, underlining the strong ties between Welsh culture and language. The court of governors was chosen with an eye to representing the entire Welsh nation. The entrance hall of the new museum featured a range of specifically Welsh exhibits. By 1910 the museum had established a system, whereby a group of so-called 'correspondents' worked up and down the country to identify 
and bring to the museum such objects which were deemed of national importance (Bassett 1982, 1983, 1984; Morgan 2007; Mason 2007; Watson 2011).

\section{National museums and the representations of regionalism}

Wales is an example of cultural nationalism that stopped short of seeking independent statehood, although most representatives of Welsh nationalism around 1900 would have rejected the idea of their country being a region of Britain. Yet, generations of scholars have struggled to demarcate 'nation' and 'region'. At the end of the day, the judgement is often in the eye of the beholder. Historically, regions can become nations and nations can turn into regions. But the claim to nationhood involves a greater sense of authenticity and cultural/linguistic/ethnic/ political difference to a constructed 'other' than the claim to being a region. Above all, it involves a denial of basic similarities with neighbouring 'others'. In fact, in the age of nationalism in the nineteenth century, regions became important building blocks of nations almost everywhere. Regions had their own cultural/ linguistic/ethnic/political specificities, but they had to be compatible with the nation that they were part of. Nation builders in the nineteenth century were attracted to the idea of a region, because regional identities had often been established long before national ones. Hence, in Europe regional often preceded national museums. In Norway, for example, regional museums were opened in Bergen in 1824 and in Tromsø in 1875, whereas a Norwegian national museum was only established in the twentieth century (Amundsen 2011).

In France, 15 museums were established at the level of the départements by national legislation in 1801. Behind this was an attempt to concentrate in the museums of Paris, especially the Louvre, all works of art and antiquities deemed to be of national importance and to designate 'second-rank' antiquities and art work to the departmental museums. Furthermore, the narratives that were to be found in the latter were all planned to be streamlined according to the one national narrative presented in Paris. So far the story befits a nation-state often seen as the archetype of a highly centralized system. However, many French towns had established their own museums from the seventeenth century onwards and the stories told there were highly particularistic. What is more, the new departmental museums often developed a sense of their own particularity and put up resistance to the nationalizing narrative promoted by Paris. Many regionalists wanted to strengthen regional identity this way rather than insert the region into the wider national narrative. There were even demands to return works of art of regional significance to the regions from their location in Paris, where they had been transported because of their alleged national significance. At the turn of the century, in areas such as Provence, regional museums asserted their differences vis-à-vis Paris. Such tensions could also be observed in Paris. At the Musée Ethnographie du Trocadéro, established in 1874, a room was added in 1886 that presented the folk cultures of the different regions of France. On the one hand, this was an attempt to tell a story of national unity in diversity, but it was also, on another level, a way of reaffirming 
Parisian superiority over the backwardness of France's provinces by putting the French regions on the same level as the culture of the 'savages' of Asia and Africa displayed in adjoining rooms (Dymond 2012).

Regions, not just in France, but in many European nation-states, were heavily represented in national museums. They were portrayed as constituting nations and yet they also had to be shown to have their own specificities - unity in diversity was the theme highlighted by many regional museums, whether nationalized or not, in nineteenth-century Europe. If we take the example of Bulgaria, the People's Museum (Naroden Muzei), referred to above, was built through the help of many intellectuals, especially school teachers, military personnel and priests, who donated various objects from different parts of the country. Hence the national museum would not have been successful without the active participation of regions making up the new Bulgaria. In its collection it was oriented towards archaeology and ethnography and it told a story of the revivalist unification of all the lands inhabited by the Bulgarians, a potentially expansionist storyline, which was repeated throughout the Balkans and was to exacerbate the many border conflicts in the region. In the first decade of the twentieth century, the People's Museum, with the active help of the Ministry of Education, encouraged the foundation of a whole host of regional museums in different parts of Bulgaria, which also collected and displayed objects of archaeological and ethnographic interest following the same narrative. It is a good example of how regional and national museums could work hand-in-hand (Vukov 2011).

The most effective national master narratives were often those that could accommodate plurality - including regional plurality. National museums had to demonstrate unity though negotiating difference - that is as true for spatial identities as for non-spatial ones, such as issues of class, religion, ethnicity/ race and gender. It was no good denying those differences; they had to be narrativized, but within a wider narrative that would ultimately show that all those differences could be accommodated within the nation and that the nation was only stronger because of those differences. Hence the narrative had to turn a potential weakness into a strength. The democratic museum, which emerged together with democratic mass societies from the last third of the nineteenth century onwards was better at allowing for such pluralism than dictatorial, monarchical and authoritarian museums, which tended to be less pluralist in their negotiation of difference.

\section{Cultural transfer and transnationalism}

Transnationalism was built into national museums from the very beginning. We referred above to the origins of the national museum in Europe in the era of the Napoleonic Empire. The pioneering examples of attempts to depict the essence of the French nation in museums were received and adapted across the European continent, albeit in ways that often countered the hegemonic aspirations of the French empire-nation (Sherman 1989). But European national museums also 
brought the world to the nation and integrated it into a civilizational narrative of progress, which invariably depicted one's own nation as marching at or least towards the front of progress and civilization (Pratt 1992).

The museum buildings, often purpose-built in the nineteenth century, followed a specific grammar of national identification that was, despite its historical specificity, transnational in its imaginaries. Emerging in the late eighteenth century, neoclassical designs dominated everywhere, only to be replaced from the second third of the nineteenth century with Romantic designs and eventually towards the turn of the century with historicist architecture. Greek temples and Italian palaces were popular styles for national museums in nineteenth-century Europe. Invariably, these were situated in the capitals of nations and were part and parcel of a whole plethora of national buildings, including national archives, libraries and academies but also operas, theatres and parliamentary as well as court buildings (Dana 2004).

Before the National Museum of Wales was established in 1907, its first director, W.E. Hoyle, visited museums in Berlin, Frankfurt and Stockholm in order to determine what architectural form the new museum in Cardiff should have. He was, in any case, someone who had travelled widely and had an excellent knowledge about how such institutions were organized in different parts of Europe - a knowledge that stood him in good stead when he accepted the post of organizing the new National Museum of Wales (Bassett 1982: 167; Bassett 1983: 191-3).

The Roman-Germanic Museum in Mainz served as a model for Napoleon III's museum of French antiquities in St. Germain-en-Laye. The latter adopted not only the extensive use of plastercasts but also the same chronological ordering of presenting history in terms of successive peoples populating the territory. Up until the early twentieth century, there remained strong links between the museums in Mainz and in Paris (Bodenstein 2011a).

The Scandinavian Ethnographic Museum (established in 1873), which later became the Nordic Museum, served as a model throughout Scandinavia and beyond. Its founding figure, Arthur Hazelius, was widely admired and copied for his imaginative way of displaying the past (Bäckström 2011; on museum pioneers and their influence on national museums, see Hudson 1987). Thus, for example, the Danish Popular History Museum, established in 1885 by Bernhard Olsen, was inspired by Hazelius and his work in Stockholm (Zipsane 2011). The proximity of intellectual cultures often mattered when it came to influences across national boundaries. Hence, for example, the attempts to create an Estonian national museum looked towards Finland. Although the immediate impetus was the death of the Estonian nationalist Jakob Hurt and the need to do something with his immense folklore collection, the concrete steps of turning Hurt's collection into the Estonian National Museum, inaugurated in 1909, at several steps took inspiration from the Finnish example. It was attractive not the least because of its geographical and cultural proximity (Kuutma 2011). Other examples of the strength of transnational practices, for example, in the realm of colonial art museums (Küster 2010), could easily be added, but the message is hopefully clear: the national museum landscape in nineteenth-century Europe was an intensely transnational affair. 


\section{Conclusion}

Nineteenth-century national history museums were powerful instruments of national politics. They constructed and stabilized national master narratives, and they built national identities on which national solidarities were founded. They sometimes acted in close alliance with existing states, but they also challenged these and promoted national understandings that were in conflict with power and the prevailing forms of the state. National museums came in many shapes and forms: archaeological, ethnographic, folk history and history museums stood next to art, imperial, military, technical, natural history and a whole host of specialist museums. The origins of the national museum have been located in the French revolution, when the Louvre was first opened to the public and when the Museum of French Monuments was founded. While the collections of those museums were based on medieval and early modern private collections, mainly those of royal houses, princes, aristocrats, the Church and also rich private burghers, they now became public in a way that indicated a new relationship between the state and its citizens. National museums are therefore classic institutions of modernity, even if many of them have pre-modern precursors, with which they overlap considerably. It is, after all, striking to what extent the aristocracy and monarchy remained active and vital players in national museums throughout much of nineteenth-century Europe. Nevertheless, it was an aristocracy and a monarchy that had nationalized and modernized itself to a significant degree. In many parts of Europe, the old elite had successfully made the transition from pre-modern to modern times - arguably nowhere more so than in Britain. Hence we can say that the power and appeal of the national museums in Europe stemmed, above all, from a new definition of the relationship between territoriality and identity that was thoroughly modern.

While some of the most striking examples of national museums came from longestablished nation-states such as France (the Louvre), Britain (the British Museum), Spain (the Prado) or Sweden (the Scandinavian Ethnographic Museum), it has been argued above that it was the new nation-states in nineteenth-century Europe that were most vociferous in establishing and promoting the idea of the national museum. They often used the older models but developed a nationalizing narrative for themselves, guided by a pedagogical impetus that was more immediate and direct than was the case for the older museums. Yet, the nineteenth century was still in many ways the age of empire rather than that of the nation. Undoubtedly, empire figured strongly as a vital 'other' in those national museums belonging to nation-states that had emerged through secession from empires. Still, in many empires, stories of empire merged very effectively with nationalizing narratives to make empire an integral part of the national storyline - at least in the imperial core. The effective nationalization of empires in the nineteenth century was mirrored in many national museums.

If most national narratives in the national museums of the nineteenth century ended in the actual formation or proclamation of a future nation-state, there were exceptions to that rule. The example of Wales has been used here to highlight cases 
of national museums that championed a national storyline but stopped short of calling for their own nation-state. Forms of cultural autonomy were regarded as sufficient in maintaining a unity in diversity narrative that did not, at least not in the nineteenth century, threaten the multinational British state. The case of Wales also raises the question when a region becomes a nation. Looking at the interrelationship of national and regional museums, we found that in most parts of Europe the latter were essential building blocks of the former. In a few cases they could also challenge the national ones, but this was rather the exception than the rule. Overall then, this article has highlighted the complex interrelationship between different spatial levels in regional museums: the national was deeply imbued with regional and transnational, mostly imperial, storylines and can only be properly understood in its relational positioning to other 'regimes of territoriality' (Maier 2000).

Finally, this chapter has also highlighted the strong transnationalism that was in play in the formation and development of national museums in nineteenth-century Europe. National museums were hardly ever purely national affairs. Rather, they often looked beyond national borders to find inspiration and adapt 'foreign' practices to suit their own national needs. Such transnational practices in the formation of the European national museum landscape also explain many common European characteristics. What they collected, how they collected, the agents involved in collecting, the collecting principles, the ways of exhibiting what was collected, the pedagogical aims of enlightening and educating national publics, the attempts to establish authenticity, deep origins and historicity for their respective nations and thereby make 'their' nation a respected equal among the European community of nations - all this contributed to a European cultural form that became one of the most successful export articles of Europe in the age of twentieth-century imperialism. The European national museums set up powerful self-images and created equally powerful images of 'others', which made them breeding places for enmities and conflicts (Knell et al. 2010). Nevertheless, this also made them attractive to a twentieth-century generation of nationalists in the colonized world who sought to adapt the national museums to their anti-colonial needs (Simpson 2001).

\section{Notes}

Much of the information on national museums is taken from the results of the Eunamus research team that was presented at Eunamus conferences in Bologna and Brussels. I am grateful to the reports written by these researchers on the development of national museums in diverse European countries and acknowledge a deep debt to their research.

$1 \mathrm{I}$ am grateful to Peter Aronsson for pointing this out to me.

2 For more details please see Dominique Poulot's chapter in this volume.

\section{References}

Alexander, E.P. (1983) 'Oskar von Miller and the Deutsches Museum: The Museum of Science and Technology', in Museum Masters: Their Museums and their Influence, Nashville, TN: American Association for State and Local History, 341-75.

Amari, M. (2001) I musei delle aziende: La cultura della tecnica tra arte e storia, Milano: Franco Angeli. 
Amundsen, A.B. (2011) 'National Museums in Norway', Eunamus Congress, Bologna, April. Apor, P. (2011) 'The National Museum in Hungary: approaches to its analysis', Eunamus Congress, Bologna, April.

Aronsson, P. (2011) 'Explaining national museums: exploring comparative approaches to the study of national museums', in S. Knell, P. Aronsson and A.B. Amundsen (eds.) National Museums: New Studies from Around the World, London: Routledge, 29-54.

Aronsson, P. and Bentz, E. (2011) 'German national museums: promoting competing territorial communities, anchoring revolutionary change', Eunamus Congress, Bologna, April.

Augusteijn, J. and Storm, E. (2012) Region and State in Nineteenth-Century Europe: NationBuilding, Regional Identities and Separatism, Basingstoke: Palgrave Macmillan.

Bäckström, M. (2011) 'Loading guns with patriotic love: Arthur Hazelius's attempts at Skansen to remake Swedish society', in S. Knell, P. Aronsson and A.B. Amundsen (eds.) National Museums: New Studies from Around the World, London: Routledge, 69-87.

Bădică, S. (2011) 'What's in a name? National museums in Romania', Eunamus Congress, Bologna, April.

Bassett, D.A. (1982) 'The making of a national museum: part 1', Transactions of the Honourable Society of Cymmrodorion, 153-85.

-(1983) 'The making of a national museum: part 2', Transactions of the Honourable Society of Cymmrodorion, 187-220.

(1984) 'The making of a national museum: part 3', Transactions of the Honourable Society of Cymmrodorion, 217-316.

Bennett, T. (2006) The Birth of the Museum: History, Theory, Politics, London: Routledge.

Berger, S. with Conrad, C. (2015) The Past as History: Historical Consciousness and National Identity in Modern Europe, Basingstoke: Palgrave Macmillan.

Berger, S. and Miller, A. (eds.) (2015) Nationalizing Empires, Budapest: Central European University Press.

Berger, S., Conrad, C. and Marchal, G. (eds.) (2008-15) Writing the Nation, 8 vols, Basingstoke: Palgrave Macmillan.

Bergveldt, E. (2012) 'The colonies in Dutch national museums for art and history 18001885', in H. Dunthorne and M. Wintle (eds.) The Historical Imagination in NineteenthCentury Britain and the Low Countries, Leiden: Brill, 87-108.

Bergveldt, E., Meijers, D.J., Tibbe, L. and van Wezel, E. (eds.) (2009) Napoleon's Legacy: The Rise of National Museums in Europe, 1794-1830, Berlin: G. and H. Verlag.

Bligaard, M. (2000) 'The image of Denmark: museums as sanctuaries of identity', in J.M. Faldmark (ed.) Heritage and Museums: Shaping National Identity, Shaftesbury: Donhead, 281-302.

Bodenstein, F. (2011a) 'National museums in France', Eunamus Congress, Bologna, April.

- (2011b) 'National museums in Portugal', Eunamus Congress, Bologna, April.

Butler, S. (2012) Britain and its Empire in the Shadow of Rome: The Reception of Rome in SocioPolitical Debate 1850-1920, London: Bloomsbury.

Canadelli, E., Troilo, S. and Verga, M. (2011) 'Cultural heritage and national museums in Italy (18th-21st Centuries)', Eunamus Congress, Bologna, April.

Carbonell, B.M. (2012) Museum Studies: An Anthology of Contexts, 2nd edition, Oxford: Blackwell.

Caygill, M.L. (1981) The Story of the British Museums, London: British Museum Publications.

Caygill, M.L. and Date, C. (1999) Building the British Museum, London: British Museum Publications.

Clark, W. (2006) Academic Charisma and the Origins of the Research University, Chicago: Chicago University Press.

Clemens, G. (2012) 'Bulwark of traditions: the European nobility and regional and national historiography in the nineteenth century', in I. Porciani and J. Tollebeek (eds.) Setting the Standards: Institutions, Networks and Communities of National Historiography, Basingstoke: Palgrave Macmillan, 330-50.

Conn, S. (2011) 'Science museums and the culture wars', in S. MacDonald (ed.) Companion to Museum Studies, Oxford: Blackwell, 494-508. 
Cornelis, S. (2000) 'Le Musée du Congo belge, vitrine de l'action coloniale (1910-1930)' in Du Musée Coloniale au Musée des Cultures du Monde, Paris: Maisonneuve and Larose, 71-85.

Crane, S. (2000) Collecting and Historical Consciousness in Early Nineteenth-Century Germany, Ithaca, NY: Cornell University Press.

Dana, R.C. (2004) 'The gloom of the museum', in G. Anderson (ed.) Reinventing the Museum: Historical and Contemporary Perspectives on the Paradigm Shift, Walnut Creek, CA: AltaMira, 13-29.

Daniels, S. (1993) Fields of Vision: Landscape Imagery and National Identity in England and the United States, Cambridge: Polity.

De Caro, S. (2003) Il Museo Archaeologico Nazionale di Napoli, Naples: Electa Napoli.

Dewhurst, K. and MacDowell, M. (1981) 'Popular culture and the European folk museum', in F.E.H. Schroeder (ed.) Twentieth-Century Popular Culture in Museums and Libraries, Bowling Green, OH: Bowling Green Popular University Press, 107-19.

Dymond, A. (2012) 'Displaying the Arlésienne: museums, folklife and regional identities in France', in T. Baycroft and D. Hopkin (eds.) Folklore and Nationalism in Europe during the Long Nineteenth Century, Leiden: Brill, 137-60.

Eisenstadt, H. (2015) 'Modernization, imperial nationalism and the ethnicisation of religious identity in the late Ottoman Empire', in S. Berger and A. Miller (eds.) Nationalizing Empires, Budapest: Central European University Press.

Forster-Hahn, F. (1994) 'Weihestätte der Kunst oder Wahrzeichen einer neuen Nation: die Nationalgalerie(n) in Berlin 1848 - 1968', in P. Bloch, C. Hölz and U. Steiner (eds.) Berlins Museen: Geschichte und Zukunft, Berlin: Deutscher Kunstverlag, 147-64.

Gazi, A. (2011) 'National museums in Greece', Eunamus Congress, Bologna, April.

Glaser, H. (1992) 'Ein bayerisch historisches Museum im weitesten Sinn des Wortes', in M.-L. von Plessen (ed.) Die Nation und ihre Museen, Frankfurt/Main: Campus, 182-90.

Hein, D. (2009) 'Kunst, Museen und Bürgertum. Ein Beziehungsgeflecht im Umbruch', in W. Plumpe and J. Lesczenski (eds.) Bürgertum und Bürgerlichkeit: zwischen Kaiserreich und Nationalsozialismus, Mainz: Philipp von Zabern, 153-64.

Hudson, K. (1987) Museums of Influence, Cambridge: Cambridge University Press.

Jennings, G.M. (1991) 'Museums and cultural understanding', in J.H. Falk, L.D. Dierking and S. Foutz (eds.) In Principle, In Practice: Museums as Learning Institutions, Lanham, MD: Rowman and Littlefield, 91-106.

Kamen, M. (2008) Imagining Spain: Historical Myths and National Identity, New Haven: Yale University Press.

Kaplan, F. (1994) 'Introduction', in F. Kaplan (ed.) Museums and the Making of Ourselves: The Role of Objects in National Identity, Leicester: Leicester University Press, 1-18.

Knell, S., Aronsson, P. and Amundsen, A.B. (eds.) (2010) National Museums: New Studies from Around the World, London: Routledge.

Komlosy, A. (2015) 'Imperial cohesion, nation-building and regional integration in the Habsburg Empire', in S. Berger and A. Miller (eds.) Nationalizing Empires, Budapest: Central European University Press.

Köstering, S. (2005) 'Biology, heimat, family: nature and gender in German natural history museums around 1900', in T. Lekan and T. Zeller (eds.) Germany's Nature: Cultural Landscapes and Environmental History, Ann Arbor: University of Michigan Press.

Kriller, B. (2000) 'Das kunsthistorische Museum - Architektur als Instrument der Erinnerung Malerei als Zeitzeuge der Wissenschaft', in M. Csáky and P. Stachel (eds.) Speicher des Gedächtnisses: Bibliotheken, Museen, Archive, Teil 1: Absage an und Wiederherstellung von Vergangenheit: Kompensation von Geschichtsverlust, Vienna: Passagen, 215-28.

Küster, B. (2010) 'The first colonial art museum and transnationalism in the visual arts: Saint Denis, La Réunion, 1912', in W. Goebel and S. Schabio (eds.) Locating Transnational Ideals, London: Routledge, 157-74.

Kuutma, K. (2011) 'National museums in Estonia', Eunamus Congress, Bologna, April.

Lanzarote, G. and María, J. (2011) 'Crown, church and people: history of national museums in Spain', Eunamus Congress, Bologna, April. 
Lekan, T. (2009) Imagining the Nation in Nature: Landscape Preservation and German Identity 1885-1945, Boston: Harvard University Press.

Lorrette, J. (1965) 'La section iconographique du Musée Royal de l'Armée à Bruxelles: ses richesses et son rayonnement', Revue Internationale d'Histoire Militaire, 24: 483-506.

Maier, C. (2000) 'Consigning the twentieth century to history: Alternative narratives for the Modern Era', American Historical Review, 105: 807-31.

Mason, R. (2007) Museums, Nations, Identities: Wales and its National Museums, Cardiff: University of Wales Press.

Mayr, O. (1990) The Deutsches Museum: German Museum of Masterworks of Science and Technology, London: Scala Books.

McClellan, A. (1994) Inventing the Louvre: Art, Politics and the Origins of the Modern Museum in Eighteenth-Century Paris, Cambridge: Cambridge University Press.

Morgan, P. (2007) 'The Creation of the National Museum and National Library', in J. Osmond (ed.) Myths, Memories and Future: The National Library and National Museum in the Story of Wales, Cardiff: Institute of Welsh Affairs, 13-22.

Osterhammel, J. (2009) Die Verwandlung der Welt: eine Geschichte des 19. Jahrhunderts, Munich: C.H. Beck.

Pettersson, S. (2011) 'National museums in Finland', Eunamus Congress, Bologna, April.

Porciani, I. (2012) 'Nations on display: history museums in Europe', in I. Porciani and J. Tollebeek (eds.) Setting the Standards: Institutions, Networks and Communities of National Historiography, Basingstoke: Palgrave MacMillan, 130-52.

Poulot, D. (1992) Musée, Nation, Patrimoine, 1789-1815, Paris: Gallimard.

Pratt, M.L. (1992) Imperial Eyes: Travel Writing and Transculturation, London: Routledge.

Quack-Eusthathiades, R. (1984) Der deutsche Philhellenismus während des griechischen Freiheitskampfes 1821-1827, Munich: Oldenbourg.

Rauchensteiner, M. (1997) 'Das Heeresgeschichtliche Museum in Wien', in H.-M. Hinz (ed.) Der Krieg und seine Museen, Frankfurt/Main: Campus, 57-72.

Shaw, W.M.K. (2003) Possessors and Possessed: Museums, Archaeology and the Visualization of History in the Late Ottoman Empire, Berkeley: University of California Press.

Sherman, D.J. (1989) Worthy Monuments: Art Museums and the Politics of Culture in NineteenthCentury France, Cambridge, MA: Harvard University Press.

Simpson, M.G. (2001) Making Representations: Museums in the Post-Colonial Era, London: Routledge.

Stara, A. (2012) 'National history as biography: Alexandre Lenoir's Museum of French Monuments', in K. Hill (ed.) Museums and Biographies: Stories, Objects, Identities, Woodbridge: Boydell Press, 265-78.

Telesko, W. (2006) Geschichtsraum Österreich. Die Habsburger und ihre Geschichte in der bildenden Kunst des 19. Jahrhunderts, Vienna: Böhlau.

Thijs, K. (2008) 'The metaphor of the master: "Narrative Hierarchy" in national historical cultures of Europe', in S. Berger and C. Lorenz (eds.) The Contested Nation: Ethnicity, Class, Religion and Gender in National Histories, Basingstoke: Palgrave Macmillan.

Tollebeek, J. (1998) 'Historical representation and the nation-state in Romantic Belgium (1830-1850)', Journal of the History of Ideas, 59: 329-53.

Trümpler, C. (2008) Das große Spiel: Archäologie und Politik zur Zeit des Kolonialismus 18601940, Cologne: DuMont.

Vukov, N. (2011) 'Report on Bulgaria', Eunamus Congress, Bologna, April.

Watson, S. (2011) 'National Museums in Wales', Eunamus Congress, Bologna, April.

Williams, C.H. and Smith, A.D. (1983) 'The national construction of social space', Progress in Human Geography, 7: 502-18.

Wolbring, B. (2009) 'Politisch motivierte Popularisierung im Fall des Germanischen Nationalmuseums', in C. Kretschmann (ed.) Wissenspopularisierung. Konzepte der Wissensverbreitung im Wandel, Berlin: de Gruyter, 211-20.

Zipsane, H. (2011) 'On the development of national museums in Denmark', Eunamus Congress, Bologna, April. 


\section{2}

\section{MUSEUMS OF CIVILIZATION, MUSEUMS OF STATE, MUSEUMS OF IDENTITY}

\section{National museums in Europe, 1918-2000}

\section{Péter Apor}

\section{Introduction}

The chapter analyses the transformations of national museums in Europe in the twentieth century following the First World War. The period between 1918 and 2000 is marked by radical changes: the dissolution of composite states and empires after 1918, the formation of many new national states and identities, the establishment of socialist dictatorships and the escalation of the Cold War after World War II, and the collapse of the colonial system during the 1950s and 1960s (Hobsbawm 1995). Throughout the twentieth century many elites and communities developed sensitivity to loss and guilt. The mourning of the loss of human lives in the two world wars, the Holocaust and lost territories reshaped the visual and ideological outlook of national museums.

Nation-states coped with these challenges in a variety of ways and in accordance with cultural traditions, resources and historical identities. Several states initiated new historical museums. Some states cultivated art museums, whereas others promoted ethnographic ones to represent the values of the nation. The identity of 'socialist nations' was associated with a variety of cultural approaches and ethnic features, prewar historical nationalisms, new transnational federalist or 'Third Worldist' ideas. In the Soviet Union between 1945 and 1989, and after the end of the Cold War, particularly in Russia, a possible 'socialist' concept of the nation was strongly linked to the cult of the 'Great Patriotic War' and the myth of anti-Fascism (Tumarkin 1994; Merridale 1999). In Western Europe, the new challenges of the Second World War contributed to the development of a new type of memorial museums.

The sense of loss interacted with the growing influence of the idea of heritage from the 1970s onwards. The growing opportunities for tourism and the emerging travel industry that accelerated both in Western and Eastern Europe from the late 1960s considered museums primarily as sites where visitors could encounter local 
particularities, including the local landscape, sightseeing and gastronomy. Museums, in turn, began to be seen as windows through which various communities could be represented to the world. They have thus been less and less received as sites of knowledge necessary for 'cultured' or 'civilized' manners, and more and more as sites where identities could be found and appropriated.

The 1990s were equally challenging for museum representations: the corresponding tendencies of increasing multiculturalism and the return of ethnic essentialism often posed questions that national museums had to answer. Related to these currents, the history and consequences of colonialism, migration, global history and transnational socio-cultural transfers, such as the international circulation of models of Holocaust representations and atrocity exhibitions, made museum professionals and cultural elites consider appropriate ways of encouraging social awareness of such developments.

The chapter does not provide a country-by-country analysis of these processes. Instead, it addresses the major tendencies of the developments of European national museums in seven chronological but intersected themes. The section 'National museums and the compensation for loss after 1918' explores the reshaping of linkages between national museums and statehood after the First World War. The next two sections, 'Framing national identity in museums through art, history and ethnography' and 'New museums of ethnography', examine the disciplinary focus that museums devoted to displaying national identities between the two world wars. The fourth, 'Socialist patriotism represented', describes the way national museums in post-Second World War Eastern Europe coped with the tension of teleological universalist communist metanarratives and particular national identities. In the fifth section, 'Colonial museums', the shaping of post-colonial and post-imperial visual representations since the 1960s is analysed. The sixth, 'Memorial museums and museums of atrocities in Eastern Europe after 1989', examines the emergence of new memorial museums devoted to the commemoration of victims after the fall of communism. The last section, 'Ethnic multiculturalism, multicultural ethnicity', investigates the challenges that museums had to face in relation to the emergence of multicultural and neo-traditionalist ethnic identities around 1990.

\section{National museums and the compensation for loss after 1918}

The end of the First World War meant an important turning point in the institutional development of European national museums. The losses of the war affected many communities in Europe, including both the entente and the central powers. In Western Europe (for example, in France and Great Britain), it was the awareness of mass death that provided the focus of loss after the war, whereas the defeated countries in Central and Eastern Europe connected the notion of 'loss' to the loss of territories and cultural assets (for example, in Germany, Hungary and Bulgaria). Even in the victorious states in Eastern and South-Eastern Europe, elites and the educated middle classes contemplated the former lack of statehood (Poland), the missed opportunities of catching up with the leading European powers (Italy), or 
the missed achievements of 'civilization' (Romania). Such ideas - the loss of lives and mass death, the loss of territory and statehood, missed opportunities and missed civilization - became important themes represented by the national museums in these countries.

In France and in Great Britain the pressure to make sense out of the massive war efforts and sacrifices between 1914 and 1918 was linked to the cultural canons of commemorating armed conflicts (Winter 1995). Remarkably, in both countries new military museums or exhibition extensions were initiated in the early post-war years. In Paris, the Musée de l'Armée had already become an important site of mourning and pilgrimage during the war. The strong connection that the museum built between military traditions and national identity helped the institution and its visitors to incorporate the new experiences of mass death into the canons of military glory and the virtue of dying for the fatherland. The museum, hence, suggested new ways of thinking about French national identity in terms of including the sacrifices made in the victory over the aggressor within old frames, which emphasized the achievements and might of the French military on the Continent (Bodenstein 2011b: 308-9; Barcellini 2010; Westrate 1961). In Britain, a brand new museum was founded to collect and display material related to the Great War. Following a Cabinet decision in 1917, the Imperial War Museum was established in 1920 at Crystal Palace in South London. This museum was partly linked to conventional imperialist aspects of the British national identity, since it was supposed to collect material from former or present colonies, to exhibit new war machinery and tactics, and also to contribute to domestic morale. However, the institution also suggested important ways of rethinking Britishness in terms of suffering and sacrifice. The museum intended to commemorate the fallen, displaying ordinary experiences of suffering in the frontline, while it connected their meaning to the defence of rights and freedom, conventionally strong components of the British national identity (Watson and Sawyer 2011: 123-4; Condell 2002).

The case of Austria and Hungary illustrates the way national museums were able to compensate for the loss of empires in Central Europe after 1918. The former imperial museums in Vienna, the Kunsthistorisches Museum and the Naturhistorisches Museum, which were partly royal property, became state property after 1918. In many ways, they became the national museums in the new Republic of Austria, which replaced the Austrian Empire (Bentz and Raffler 2011: 28; Mattl 1995). The Hungarian National Museum, which originally represented the cultural and historical identity of the Hungarian nation in terms of the old kingdom, after $1918 \mathrm{had}$ to conform its role to a state representing only one part of the cultural community and, at the same time, to address the politically and geographically fragmented condition of the national body (Apor 2011b: 416; Fejös 1965).

The contested legacy of Austria-Hungary was reified through various conflicts over the just possession of museum objects. In 1919, the government of Czechoslovakia claimed the 'return' of museum objects that had originally come from geographical locations that became parts of the Czechoslovak state following 
World War I. In fact, several such objects had been collected in 1896, 1914 or 1918 by the Budapest authorities to demonstrate the evidence of 'Magyar cultural presence' in the ethnically non-Hungarian areas of the old Kingdom (Hudek 2011: 832-3; Mruškovič et al. 2005: 64). By similar reasoning, the command of the Romanian forces, which occupied Budapest after the fall of Béla Kun's Bolshevik dictatorship in August 1919, also declared the right to objects that had allegedly originated from the territory of Transylvania, which was granted to the post-war Romanian state by the Versailles (Trianon) peace treaty. In 1921, in turn, the National Museum of Hungary obtained welcomed, although somewhat unexpected, new objects. The Venice Treaty between Austria and Hungary, which established new state borders and settled the issues of contested territories, also granted approximately 1,000 artefacts to Hungary from the imperial collection previously housed in Vienna. This acquisition included the early sixteenth-century sword of King Ulászló II and full plate armour of King Louis II (Apor 2011b: 415-16; Kemenczei 1996: 21-4).

The case of post-World War I Poland elucidates how national museum institutions could retrospectively compensate for the previous lack of statehood. In 1916, the Museum of Fine Arts in Warsaw was renamed the National Museum. The museum had been founded in 1862 as a territorial centre of education and culture for the Polish regions of the Russian Empire. The tsarist authorities encouraged the relatively neutral European art history perspective in order to contain Polish nationalist separatist cultural movements. As a consequence, the Warsaw museum exhibited no Polish objects of art when it suddenly became a National Museum. In 1916, however, there had already been another national museum serving Polishspeaking communities: the National Museum in Cracow, in the Austro-Hungarian Empire. The Cracow institution had been founded in 1879 as a Galician provincial museum inside the Austro-Hungarian Monarchy (Mazan 2011: 680-1). However, in 1916 Polish political and cultural elites were already anticipating the creation of an independent Polish state in some form as the possible outcome of the war. Warsaw, the seat of provincial governments and university and of the last Polish kings, was the obvious choice for the future capital. In fact, the elite of the nascent state decided to refashion the Museum of Fine Arts into a National Museum in the capital in order to create a central symbolic site of Polish culture and state. The renaming act was, in fact, an act of state-building (Wandycz 1993).

The Polish case was very similar to that of Finland and the other Baltic provinces of the tsarist empire. The institutionalization of museums of the future independent states had started already in the midst of the war, in 1916. The process began in Finland: following nineteenth-century initiatives and collecting activities, a purpose-built museum building was erected in Helsinki, then a regional capital of the Russian Empire. Next year, the province became the independent state of Finland and the museum in Helsinki its National Museum (Pettersson 2011: 273-5). In Lithuania, the first central museums in the seat of the government were established in 1921: a military history and an art museum in Kaunas. Kaunas became the capital of Lithuania in 1920, as Vilnius was annexed by Poland (Rindzevičiūtè 
2011: 526). State-building implications were clear also in the successor states of the former Habsburg Empire. In Prague, the National Museum, which in fact was renamed so in 1918, and that had been a cultural institution fostering Czech national identity throughout the nineteenth century, now aspired to represent the newly institutionalized Czechoslovak nation (Apor 2011a: 207). The transformation of regional identities into national ones in Western Europe also started during the interwar period, a point illustrated by the foundation of the National Museum in Wales in 1927 (Mason 2007: 6-49).

Post-World War I states in South-Eastern Europe, particularly Romania and Yugoslavia, confronted not only the legacy of Austria-Hungary, but also that of the Ottoman Empire. Even though it is true that a Serbian National Museum had been founded in Belgrade in 1844, its previous firm foundation as the museum of all Serbs was partly undermined after 1918. Independent Serbia found herself as the centre of a new state, Yugoslavia, with territories and populations inherited from the dismantled Austro-Hungarian monarchy. Although Yugoslavia was founded as a federal state, a kingdom of Slovenes, Croats and Serbs, there were strong efforts from the creation to establish a centralized new national identity of Yugoslavs. The former Serbian National Museum in Belgrade, the new Yugoslav capital, was to represent an all Yugoslav cultural and political identity (Manojlović-Pintar and Ignjatović 2011: 788-90).

The example of Romania also illustrates how important national museum institutions were for assuaging the cultural consciousness of allegedly lost opportunities of 'civilization'. The cultural and political elites of the post-war Romanian state were also motivated by the nationalist contest between Hungary and Romania and by the idea of 'catching up' with the 'civilizing' achievements of Budapest, which were perceived by the striking asymmetry of the state of national museums in the two countries. Romania seized vast amounts of territories both in the West Transylvania - and in the East - Bessarabia - following World War I. According to the ideology of Western European nation-states and nationalism, which the Romanian elites took as their model, the state of Greater Romania represented the unity of all Romanians and, essentially, a homogenous national territory. In fact, 25 per cent of the population of the post-1918 Romanian state consisted of non-Romanian ethnic minorities including Hungarians in Transylvania, a former politically and culturally dominant ethnic group backed by the previous Hungarian administration in the region. Although a united independent Romanian state had existed since 1852, possessing a National Museum founded by the wealthy boyar Mihalache Ghica, after 1918 the elite of the expanded state felt the pressing need to create a central museum that could represent the newly established national state of 'all Romanians' (Badica 2011: 721-2).

The genesis of national museums was linked to ideas of 'European' and 'Western' civilized states. Notably, Turkey had no national museums before the establishment of the republic in 1923, which was understood by the new republican elites as a move from an 'Oriental' imperial Ottoman civilization to a secular superior 'European' one. During the first two decades of the new republic, a series of state-funded 
museums were set up, clearly modelled on European-style exhibitions and genres of display. The new museums of history (the Topkapi Palace Museum, 1924), the partly rearranged archaeological exhibitions (in Istanbul and Ankara) and art (the Istanbul Museum of Painting and Sculpture, 1937) provided rationally ordered chronologies and highlighted relationships with the West and situated the archaeological objects of Asia Minor in the metanarrative of Western civilization (Köksal 2010: 164-72; Shaw 2011: 927-33, 938-40; Savino 2012: 255-9).

\section{Framing national identity in museums through art, history and ethnography}

The new independent states and the creation of new borders were mostly the unpredictable outcome of the turbulent wartime years. Yet, these events compelled the cultural and political elites to reinterpret the role and function of national museums. The classical museums of civilization, which had claimed for their states a position in a universal European civilization, began to highlight particularities and differences allegedly associated with their nations. The national museums thus began to construct appropriate identities for their states. Such ways of constructing identities led to the reappraisal of nineteenth-century nationalist historicism and the appropriation of national mythology that started to feature in the exhibitions of new national museums. European state elites after 1918 began to justify independence, expansion or new borders as a logical, sometimes even necessary, outcome of historical processes, social and cultural development, and geographical and natural circumstances.

The selection of major disciplines, which national museums used to reify such considerations, was shaped largely by the legacy of the founding period and late nineteenth-century nation-building processes. However, there was a certain tension between the goals of national museums between whether to represent national identities or the genres and disciplines that national museums were usually born with. History and art but also folklore are universal terms that apply to global processes, and each national or any other political or cultural community can claim to be part of these. All these three modalities of museum representation had developed relatively sophisticated ways to represent temporal continuities and identities in terms of the hierarchical evolutionary history of progress. The continuity of nations framed by European civilization and the stages of aesthetic progress as illustrated by art and the evolution of human societies were the relevant grand themes addressed by modern museums (Bennett 1995: 39-47). Such metanarratives normally referred to transnational, European or imperial frames, and yet they had to tackle an increasingly nationalizing continent after 1918. One of the crucial questions of national museums during this period was how to tell national stories in international languages?

Since these universal categories began to be increasingly connected with the idea and understanding of what a national state was, national museums were gradually 'nationalized' during the interwar period. Besides historical legacies, the choice of disciplines that national museums could use was also linked to regional 
particularities. The heritage of the Middle Ages, which was connected to the idea of national empires, made history the crucial visual means of museum culture in countries such as Germany or Hungary. The tsarist empire, which had largely built its state identity by creating formidable collections of European high art and culture, influenced the taste and cultural practices of the regional elite in the successor states. In Yugoslavia, too, art played a special role in forging the country together, as it did in the smaller states of Western Europe such as the Netherlands. The rich heritage of ancient architecture and archaeology in Southern Europe, in contrast, linked cultural identities to visual languages reified through archaeological objects. The most spectacular exploitation of the Middle Ages for political purposes in Germany was made by the Nazi leadership. The medieval setting of Nuremberg as well as its formidable historical collections in the Germanisches Nationalmuseum was abused to stage large-scale Nazi party rallies to enact the role of the ruling party as the master of German history. The Germanisches Nationalmuseum, in fact, was not inimical to such exploitation. Its original idea was to construct an image of the nation independently of actually existing state borders and thus to get beyond the political fragmentation of Germany. The museum based its concept on cultural, linguistic and ethnic aspects to link all Germans together regardless of which state they lived in. However, the ethnic understanding of the nation had imperialist implications as the concept soon expanded to citizens of Austria and Switzerland as well as to all German-speaking populations in (Eastern) Europe. The original glorification of the Middle Ages as an implicit manifestation of the German national spirit was easily appropriated by the Nazis, who further militarized the exhibitions in Nuremberg and praised the 'German knight' as the model of true German imperial (male) citizens (Kammel 2012: 224-7). The Nazis also initiated ambitious plans to reshape Berlin's Museuminsel according to a manifest revanchist and racist ideology. A 1934 plan included the idea of a Great War Museum, a future 'race' museum based on ethnographic collections, a Germanic museum and also a classic museum of civilization focusing on nineteenth-century art and high culture to represent German national achievements and superiority in these fields (Aronsson and Bentz 2011: 336).

The glorification of the Middle Ages played a similar role in Hungary, although its pro-Nazi abuse remained mostly confined to semi-official fascist subcultures, where the loss of territories and imperial culture could be compensated for by evoking the myth of medieval Hungary as a great power. The Hungarian National Museum's major historical exhibition in the interwar period was dominated by a conservative-nationalist political culture. This historical exhibition covering the periods from early medieval Hungarian history up until the nineteenth century focused on the culture, lifestyle and erudition of the noble classes, pursued a history of bellicose spirit and showed an appreciation of eighteenth-century Habsburg court civilization. In turn, it largely neglected the representation of the lower classes, peasants in particular, avoided the interpretation of the peasant revolt in 1514 and also ignored the history of the Enlightenment and its impact on Hungarian political thought (Fejös 1965: 298-301). 
Detached from the Russian Empire, Polish elites considered the necessity of a central museum, a National Museum to exhibit the historical development of the Polish nation, particularly by displaying culture and nature. Culture was seen as a particularly important means to forge together interwar Poland, which was recognized as a multiethnic state. It was also seen as a matter that would create a Polish consciousness and identity, making true Polish citizens out of all sorts of ethnic groups. The Warsaw Museum, hence, tried to retrospectively create a continuity of historical experiences of the Polish nation and state. The old collections of classic European art were replaced with Polish national art from 1919 onwards. The museum staff installed exhibitions that demonstrated the commitment of ethnic Poles to the cause of an independent fatherland during the Napoleonic wars, anti-Russian insurrections, or the mythical Polish contribution to the defence of Vienna against the Ottomans in 1683 (Mazan 2011: 682; Masłowska 2002). National museums in interwar Poland, in a way, provided cultural compensation for the lost centuries of continuous statehood (Wandycz 1993). In this way, they confirmed the myths of Polish nationalism, particularly the idea of the destiny of Poles to sacrifice themselves for the freedom of all Europe and the obligation of all consecutive generations to shed blood for the regeneration of the country (Domańska 2000: 255-6).

Museums in several new states that had formerly been parts of the Russian Empire pursued a similar agenda. The Finnish national identity emphasized the continuity of a small nation within larger composite states. The National Museum in Finland followed contemporary European models by demonstrating a continuous narrative from prehistory through archaeological exhibitions to modern Finland as represented by historicist historical exhibitions and ethnographic displays (Fewster 2006). The museum sought to provide a comprehensive archaeologicalhistorical narrative of Finns living continuously in the territory of Finland, a narrative that is still preserved (Pettersson 2011: 267). Finnish nationalism was less aggressive towards its large neighbour and rather emphasized its inherent place in the common European history. The National Gallery, the second most important member of the triad of national museums in the country (the National Museum, the National Gallery and the Natural History Museum), continued to collect European art in general as prescribed by the legacy of the nineteenth-century founders. Within this framework, Finnish art was represented as part of broader transnational European currents and not as evidence of some imagined particular national character (Pettersson 2010). In Latvia, after the country gained independence in 1919, following a short intercourse of Bolshevik rule, art exhibitions and collecting played an important role in establishing a post-imperial national identity. The Latvian National Museum of Art, which in this period was the property of Riga Municipalities and, accordingly, called the Riga City Museum of Art, began to focus on collecting Latvian national art and actually interpreted national art in some respects in a limited ethnic sense. Remarkably enough, such nationalization and ethnicization of art was not only an anti-Russian measure; it was motivated rather by the idea of distinguishing Latvian national characteristics from German ones and thus to balance the previous dominance of the German middle classes in Baltic Sea 
cities (Kencis and Kuutma 2011: 505-6). Although Lithuanian political and cultural elites had developed their programmes of nation-building within the framework of the composite Russian state, Poland became the major target and reference point of Lithuanian nationalism after the loss of Vilnius. Accordingly, historical exhibitions began to play down the significance of Polish connections to Lithuanian history and developed a cult of the medieval and early modern Grand Duchy as some prehistory of the Lithuanian nation in the form of a glorious empire (Jankevičiūte 2010). Another component of national identity represented by museums was folk and peasant culture, which turned important as a possible means of displaying a non-Polish culture that was more associated with aristocratic high learning and arts. The outcome, despite the foundation of a few institutions, was that the independent government in between the two wars was less interested in museums, which traditionally used to represent the achievements of elites and high civilization (Rindzevičiūtè 2011: 527).

Art played a similar role in several of the smaller Western European states. Although no longer being part of empires, their elites were still making efforts to construct cultural codes that could distinguish their nations from more powerful neighbours such as France or Germany. Art in this context made a case for each nation's formidable achievements and simultaneously for a particular national character as well. A particularly eloquent case is that of the Netherlands, whose art contributed significantly to the making of a Dutch nation during the interwar period. Art, especially painting, in the Low Countries had already obtained a strong regional flavour during the sixteenth and seventeenth centuries, when rich Flemish and Dutch middle classes were able to finance a high level of artistic consumption as well as producing a good number of artists. The Flemish Renaissance, therefore, provided an extraordinary chance to create a national identity, particularly in the Netherlands (Bodenstein 2011c: 604-5).

Although playing a highly important role, the function of art in Yugoslavia differed: instead of confirming national particularities, it was used to construct supranational identities. The construction of an expansive and integrationist Yugoslav identity had already begun around 1900 when the National Museum was reconstructed and reopened. Following World War I, the museum was supposed to become the central national museum of Yugoslavia. In Yugoslavia, art was not associated with particular regions. On the contrary, it provided a neutral, universalist, non-ethnicized language that could represent an integrationist allYugoslav identity discouraging the separatism of member ethnic groups. As the Serbian National Museum viewed the nation mostly in terms of art, the expansion of a new Yugoslav identity chiefly targeted objects of art from Croatian and Slovenian artists and areas. Nonetheless, it remained an ambivalent process; while the museum endeavoured to represent simultaneously the narrative of national emancipation that culminated in the foundation of the all-Yugoslav state, its permanent exhibition was based on the collections that the museum inherited from the pre-war period: a representation of medieval Serbian culture (Manojlović-Pintar and Ignjatović 2011: 790). 
In Southern Europe, archaeology played a similar role in nation-building or even in imperialist projects. In the Mediterranean countries of Portugal, Spain, Italy and Greece, the archaeological heritage of the classical civilizations of Rome and ancient Greece were particularly abundant and visible. The material remnants and objects of this period were created as the legacy of European civilization in the late eighteenth and early nineteenth centuries due to the growing intellectual and cultural interest in history. The ideologies of emerging nation-states in the area were shaped by these broader European concerns, when elites appropriated the values that had been already attached to the origins of European civilization, which British, French and German intellectuals meant to discover in the Roman and Greek heritage. The national elites of Southern Europe developed programmes to 'nationalize' these universal European values, a process that was immensely shaped by archaeological museums (Catapoti 2012: 141, 150, 152-9).

In the interwar period, Italian and Greek elites were particularly interested in capitalizing on the classical heritage and on archaeological exhibitions. In Greece, the classical heritage appropriation was a more ambivalent process during the interwar period, although archaeology did play a massive role in shaping a modern Greek national identity. The modern Greek state and political structure formed during the 1910-20 decade, and it was the outcome of the post-World War I war with Turkey that marked the end of an expansionist Greek national identity. The modern state inherited the complementary ideas of ancient and Byzantine legacies that formed the pillars of imagining the continuous existence of the nation in the territory of the state. However, during this period it was rather the Byzantine heritage that received a spectacular representation in museums. The Byzantine and Christian Museum was established in 1914 with the idea of displaying the legacy of the 'second Greek civilization', Greek Christianity, as a link between ancient and modern Greece. After 1923 the museum obtained a more nationalist character when it was partly transformed into the museum of the 'Greek East'. The point of such transformations was to integrate refugees from Asia Minor into the concept of the nation and to preserve claims on the Greek heritage of territories presently belonging to Turkey (Gazi 2011: 379-80).

Mussolini's programme included the resurrection of the Roman Empire in order to support the expansionist claims of Italian fascism throughout the Mediterranean area. Roman civilization was appropriated as the heart of the Italian national identity. In 1929, a new institution, Museo dell'Impero Romano, was founded. In the 1930s, a major exhibition on Roman heritage was organized, which led to the creation of a new museum, Museo della Civiltà Romana, founded partly on the collections of the former museum, albeit formally inaugurated only after the war in 1955 (Troilo 2011: 472-3). Although history, or more precisely a historical mythology, was crucial to European fascism, neither Nazi Germany nor fascist Italy was particularly interested in historical museums. The fascist ideology mistrusted museums since those were considered as the lifeless repositories of dead objects (Stone 1998: 128-42; Fogu 2003: 132-64). 
Nonetheless, archaeology was used intensively in other peripheries of Europe, especially in the North, for framing national identities, such as in Norway or Ireland. In Norway, the Viking ships discovered in the late nineteenth and early twentieth centuries moved into the heart of new national museum projects in the recently independent state (1905), as highlighted by the inauguration of the Viking Museum in 1931 (Höglund 2012: 181-92). The archaeological heritage discovery in terms of 'nationalizing' museum displays was very spectacular in Ireland. Archaeology, which provided a strong connection with ancient Celtic legacy and was relatively visible throughout the country, was used as a powerful argument against inclusive expansionist British claims and for the support of constructing a non-British separatist Irish nationalism. After the Easter Rising in 1916 and the Anglo-Irish War in 1919-21, the Celtic heritage was increasingly appropriated as a distinctly anti-British factor. During the interwar period, museum exhibitions and collecting activities including excavations were improved and professionalized, chiefly due to the activity of Adolf Mahr as director of the National Museum. Mahr was an internationally renowned archaeologist, but also a German nationalist (born in Austria) and member of the Nazi Party, which made the appropriation of Irish Celtic heritage rather controversial in this period since it was not only part of a strongly nationalist anti-British movement, but also of racist hierarchical theories (Sawyer 2011: 453-4).

\section{New museums of ethnography}

The origins of the European ethnographic museums are firmly embedded in imperialism. The elites of the colonial empires boasted a variety and multiplicity of peoples and cultures and they did proudly represent such material diversity as concrete evidence of their power. This is not only true for museums exhibiting extra-European peoples and cultures, but also a description that suited most ethnographic museums concerned with the representation of domestic inland and pre-modern peasant cultures. The rediscovery of peasant culture and folkways, which was a mainstream tendency in nineteenth- and early twentieth-century European elite cultures, obtained exceptional relevance in the periphery of Europe. Innovative and high quality ethnographic museums emerged and gained the utmost relevance during the twentieth century in Scandinavia, Southeast Europe and Slovakia (Vukov 2012: 337-9).

One of the most eloquent and arguably the most influential of such museums was the twin museum near Stockholm that was opened in 1873. The Skansen and the Nordiska Museet, established by Swedish philologist, curator and ethnographer Artur Hazelius, followed the idea of imperial ethnography museums: to represent the peoples of Scandinavia, which for Hazelius was a cultural unit, in fact, a nation and for many years really a state due to the union of Sweden and Norway between 1814 and 1905. Sweden-Norway as a continental composite state without overseas colonies represented imperial grandeur through a display of domestic inland cultural diversity. Hazelius also followed the ideas of cultural nationalism, which 
refused to define the nation by the borders of respective nation-states. Such reasoning, most eloquently represented by the Germanisches Nationalmuseum in Nuremberg, claimed that members of a national community were linked together by various cultural, ethnic and linguistic commonalities, notwithstanding actual state borders. Hazelius, likewise, intended to make the cultural unity of Northerners tangible. He was an ardent promoter of Scandinavian nationalism and through his collection of ethnographic objects from Norway, Sweden, Denmark, Finland, Estonia and even from northern Germany he argued for the cultural and ethnic particularity of a (Scandinavian) nation (Hillström 2012: 34-45).

Although the idea of national uniqueness was certainly not invented by Hazelius, the open-air museum that he created became crucial in constructing a visual language of European museology that, in contrast to classic museum languages of universalism as art and history, directly displayed difference, the individual and the particular (Prösler 1996: 34). Whereas, for example, the Germanisches Nationalmuseum remained connected to the conventions of museums of civilization and constructed exhibitions of high culture, art or military achievements, and therefore searched for differences inside the inherently common visual codes of European civilization, Skansen used folk costumes, architecture and festivals, which was a code normally referred either to the extra-European tribal or intra-European peasant 'other' of elite civilization.

The Swedish model of ethnographic display certainly affected elites and professionals in the Baltic countries, which is a region that traditionally interacts with Sweden. The national museum of Latvia that exhibits the history of the area and the people was opened in the then independent nation as the Latvian Ethnography Museum in 1920. The decision of the museum staff to prefer ethnographic objects illustrates the idea of contemporary Latvian nationalism that focused on the ethnic and traditional roots of the nations, most importantly to distinguish it from German urban dwellers (Kencis and Kuutma 2011: 510-11). Ethnographical objects were at the heart of Finnish collection and exhibition activities and became a crucial component of its National Museum, as well. The way objects representing the living conditions, dressing or eating habits of ordinary people was integrated into the historical metanarrative rendered one of the core aspects of Finnish national identity tangible: the idea of the nation of ordinary folk in contrast to transnational Swedish-, Russian- or French-speaking elites, and its relative tolerance towards Swedish-speaking members (Pettersson 2011: 275).

Southeast Europe - the Balkans - has been long identified by Westerners partly as a repository of rural folk traditions and customs (Todorova 1997). Indeed, such typologies were interiorized by state elites, which could develop spectacular representations of national difference using the visual codes of ethnography museums. In Bulgaria, ethnography was always considered as the major component of important museum collections. The central state museum, the People's Museum (1892), was split into two successor institutions in 1906, when the ethnographic collections were removed into the new Museum of Ethnography, leaving the rest of the collections in the possession of the now professionalized Archaeological 
Museum (since 1909). The Museum of Ethnography was one of the main carriers of Bulgarian national identity in the interwar period, connecting such cultural identity powerfully with folkways, traditional peasant costumes and crafts. Since it had one of the richest collections in the Balkans, the Bulgarian museum affected concepts of the nation in the broader Southeast European area, particularly ideas of national culture allegedly represented by peasantry (Vukov 2011: 140-1).

Influential Romanian intellectuals of the period, particularly Alexandru TzigaraSamurcaş, who was ardently pressing political elites for many years to set up a central National Museum, also understood the nation as an ethno-national concept represented by its culture, which, in his view, was art. Yet, for him art was not an expression of elite culture, but a genuinely popular product and as such it was preserved mostly by the peasantry. Therefore, the early twentieth-century idea of the National Museum in Romania focused on peasant art and folklore, although its concept also included art from various historical periods (Badica 2011: 721-2; Pohrib 2012: 318-27). In some respects, particularly as far as the role of ethnography is concerned, the case of Slovakia follows a similar model of an ethnography-oriented museum display. The Slovak Homeland Museum (1924, Bratislava), which was clearly the project of a multiethnic Czechoslovak liberal elite and largely run from Prague, rivalled the Slovak National Museum in Martin. This museum had been long considered as the outcome of Slovak national aspirations since its foundation in 1895. It was supported by ethnic Slovak citizens and civil societies as an important institution representing a particular Slovak regional and national identity. As such, the Slovak National Museum focused on ethnography and folklore. Slovak society at large failed to interiorize the message of the Bratislava-based 'Czechoslovakist' museum and insisted on Slovak separatism and a national character (Hudek 2011: 836-7).

\section{Socialist patriotism represented}

During the 1960s, many Eastern European states of the Soviet bloc developed a culture of 'socialist patriotism' (Brandenberger 2002; Mevius 2005, 2009; Kopeček 2012), which focused on the history of the state, long-term temporal identity and continuity and understood nation as being a homogenous socio-cultural unit virtually in terms of Romantic nineteenth-century historicism. National museums were important vehicles for representing such cultures, but in different ways. In Romania, Hungary and Bulgaria, the strongest links of history exhibitions were to 'socialist patriotism'. In Poland, 'socialist patriotism' was visible mostly in the museum representations of Polish-German relationships. In the Baltic areas of the USSR, ethnography engaged itself most actively with discussions about 'socialist patriotism'. In East Germany, the concept of the 'socialist nation' had piquant implications since it was intimately connected to the rivalry with West Germany, and hence the debate obtained a broader European relevance.

The most notorious example of using militant nationalism for building support for the Communist Party was Romania, where a clear nationalist turn occurred at 
the end of the 1960s. The central component of the new ideology was the emphasis on Romanian national particularism and on its special road to socialism, which was combined with the nationalist-populist reference to the heroism of the Romanian people (Petrescu 2009). The National History Museum (1972), perceived of as the most important national museum in the country, connected Romania to its mythical origins of the past, the Stone Age and the allegedly Romanized Dacian settlements to Ceausescu's Communist Party (Badica 2010: 279-83). However, it was not revolutionary continuity or the idea of progress that linked together these epochs. It was rather the mystical idea of the nation, as eternally identical throughout all temporal changes that forged together the history of the geographical areas of contemporary Romania (Boia 2001: 15-16).

Since Transylvania was identified as the basis of the ancient Dacian settlements, the argument contained an implicit attack on conventional Hungarian national historical consciousness, which traditionally considered Transylvania as part of the Hungarian state between the ninth century and 1918. It was difficult not to read the thoroughly refurbished historical exhibition in the Hungarian National Museum, entitled 'The History of Hungary since the Conquest to 1849', opened on 31 May 1967, in this context. The displayed objects were, in general, selected and arranged to produce the impression of a temporal continuity of civilization and the national political unit (Apor 2011b: 418).

The refashioned history exhibitions in Hungary showed remarkable similarities to contemporary Bulgarian counterparts. Both museum cultures rediscovered the Middle Ages, which had previously been regarded as a retrograde period of history. The reappraisal of the medieval era emphasized the continuity of statehood, on the one hand, and linked the various historical epochs of these lands together as the successive stages of the ethnic nations. In Bulgaria, new historical exhibitions connected the modern period with ancient, particularly Thracian, heritage and with the medieval Bulgarian kingdom. The typical temporary exhibitions in the Archaeological Museum highlighted the glory of the national past and stressed the role of the strong state in the historical development of Bulgaria. The foundation of the National History Museum in 1973 was the outcome of such processes (Vukov 2011: 141-2; Sharenkova 2010: 420-2; Petkova-Campbell 2012: 70-7).

In Poland, which was the first country to become rapidly Sovietized, museums were affected somewhat earlier than in other countries of the region. Although the national themes of the interwar period were quickly dismissed, partly due to their anti-Russian implications, national museums were not inimical to nationalist interventions, especially in the new Polish territories that were acquisitioned from Eastern Germany in exchange for Eastern Poland, which had been annexed by the Soviet Union. The new Polish national museums of Poznan, Gdansk or Wroclaw re-enacted conventional anti-German symbolism and began to rearrange their exhibitions in ethnic terms. References to previous German inhabitants were cleared away as the museum displays in these regional institutions included only Polish historical ethnographical objects or works of art (Mazan 2011: 676-8; Behrends 2009). 
Even during the war, Stalinist-type communist nationalism appeared in the territories freshly occupied by the USSR in the Baltic area as part of anti-German propaganda. Soviet cultural policies normally focused on ethnic majorities in a certain area and ignored minority cultures. In Lithuania, the State Historical and Ethnography Museum represented the history of the republic as the history of ethnic Lithuanian-speaking Lithuanians and thus particularly excluded the Jews, even the Shoah, from its exhibitions. The national museums of the Soviet Republic of Lithuania took part in the re-ethnicization of contested territories, most importantly the multicultural and multiethnic city of Vilnius-Wilna, which was considered equally important for Lithuanian and Polish national identities, while at the same time being one of the most important centres of Eastern European Jewish education and culture (Rindzevičiūtè 2010).

However, the ethno-nationalist shaping of socialist patriotism triggered lasting troubles in several cases. The Estonian ethnography museum and the Open-Air Museum, created in 1940 and in the course of the 1950s, respectively, represent such complexities. The institutions became, on the one hand, integrated into official Soviet culture and were expected to display traditional peasant economies and societies as a stage in the general progressive course of history. On the other hand, the museums were allowed to pursue some semi-independent research activities among the FinnoUgric peoples of the USSR and on traditional, rural objects and architecture preceding the Soviet period. This activity at the same time conformed to official culture since it supported traditional folkways, but it could also be read as an act of nonconformism. Finno-Ugric peoples were, in fact, officially considered as backward remnants of tribal civilizations, and their near absorption by their more advanced Slavic neighbours was expected. Therefore, exhibiting the cultural values of such peoples entailed criticism of official cultural programmes. Besides, the arguments for traditional culture could invoke the Estonian peasant as the natural carrier of antiSoviet resistance, which created a myth of pure peasant resistance and ethnicized Estonian history shaped by traditional peasant cultures (Kuutma 2011: 244-5, 251-2).

Although 'socialist nations' were under construction in Cold War Eastern Europe, the process had broader European relevance. It was particularly apparent in divided Germany, where the tensions, rivalries and mutual counter-impacts of competing Cold War cultures probably had more direct effects than elsewhere. The communist government of East Germany introduced the manifest programme of creating a 'socialist nation' on German soil after 1961 with the erection of the Berlin Wall. GDR leaders started to claim that the birth of the socialist nation-state in East Germany embodied the progressive spirit of all-German history. The message of such claims was that the history of the nation would continue in fact in the GDR, which by definition became the rightful heir of pan-German cultural heritage (Kulturerbe) (Nothnagle 1999: 64-79). The promotion of cultural heritage became, in fact, a central component of GDR's cultural policy. Museums were important targets of this policy both as architecture and institutions. Berlin's Museuminsel became one of the symbolic faces of the GDR, while the Museum für Deutsche Geschichte opened a large-scale permanent historical exhibition (Penny III 1995). 
However, more than being a means of shaping German national identity, culture constituted in itself the national identity of Germany. 'Kultur' had been long imagined as a typical German antidote against superficial and artificial Western civilization, at least since the late eighteenth century (Lepenies 2006: 9, 146). During the first post-war decade, West German cultural policy also emphasized the value and importance of the classical cultural heritage. On the one hand, it contained clear intentions to undermine the legitimacy of a Sovietized Germany; West German politicians regularly invoked the conservative myth of culture that was needed as a protection against barbaric Bolshevism. It was not only Bolshevism, however, that threatened to overflow authentic German culture by its barbarity. West German cultural policy - and its East German counterpart alike kept recalling the alleged cultural barbarity of Americans, who apparently had no ability to understand culture (Aronsson and Bentz 2011: 336-8).

\section{Colonial museums}

The colonial empires of the European powers began to crumble after the First World War. Although, globally, the colonial system was dismantled only during the 1950s and 1960s, several new nationalist movements started to emerge in regions such as North Africa or South-East Asia, which forced European colonialist governments to reconsider their relationship to the lands overseas. The representation of colonies, colonial peoples and cultures had traditionally been an important component of European museums (Bennett 1995: 39-42; Prösler 1996: 22-4, 37-9; Karp and Lavine 1991: 346-62, 387-434). Museum exhibitions of high imperialism in Europe, roughly during the last two decades of the nineteenth century, produced a narrative of civilization to justify colonialist intervention. By representing black peoples, native Americans or South-East Asians as 'tribal' cultures, such exhibitions created a timeline, where European colonialists manifested the higher stages of historical progress (Fabian 1983; Reinius 2010: 403-15; Barnes 2010: 386-91). Such narratives were all-European ones: they shaped colonial exhibitions not only in London or Paris, but also ethnographic museums in Prague or Budapest (Apor 2011a: 203-12; Apor 2011b: 401-24).

While the colonies had been predominantly the subject of ethnography, new special colonial museums were founded in many European cities during the late 1920s and early 1930s. The first of those was the Tropenmuseum in the Netherlands, which was opened in 1926 (Bodenstein 2011c: 608). Its name was typical of its approach: to consider Dutch colonies as a special ethno-geographical area and to ignore all possible implications that the representation of political organization and national communities would unpleasantly have raised. The Dutch presented themselves in this museum as an enlightened colonial power that had the vocation to improve the technological level, the living conditions and political skills of the inmates (Legêne 2000). A similar French museum, Musée de la France d'Outremer, was opened in 1931 (Bodenstein 2011b: 303). The idea of extra-European France obtained long-term temporal dimensions as the museum exhibited the 
history of the empire from the Crusades, making contemporary French colonialists into the successors of medieval crusaders. The only colonial museum that had been founded prior to 1918 was the Musée du Congo Belge in Belgium (Bodenstein 2011a: 60). It focused on the civilizing mission of Belgium and on colonial education in particular (Cornelis 2000: 71-4).

When breaking with the idea of representing colonial cultures only in terms of ethnography and devoting special institutions to them, these European museums made an important claim. Their primary purpose was to justify colonial rule and to bind the overseas territories to the European centres by representing those as integral parts or some obvious extensions of the continental national borders. However, such statements elevated indigenous inhabitants of colonial territories and turned them into quasi-citizens, which was an important move towards the genesis of local movements for rights and later for independence, all the more, as it was the colonialists who exported such frames and means of representation on their own to the colonies, i.e., the movements of rights and independence (Loumpet-Galitzine 2012: 617-31). The French established the Musée National des Beaux-arts d'Alger, originally to promote the values of European civilization and French nationalism in Algeria and to serve white middle classes settled in the area. At the same time, however, the museum also transported the effective means of giving the colonies a Western type of national identity. The museum arguably contributed to the genesis of Arab nationalism in Algeria and, remarkably, turned into the National Museum of Algeria following independence (Oulebsir 2004: 194).

After World War II, in pace with the acceleration of decolonization, colonial museums started to rethink the status and meanings of their overseas collections. In a few cases, such as in Spain, the recasting of national colonial museums had already started during the war. The Museo de America, founded in 1941, represented Latin America as part of the Spanish imperial heritage or of the empire itself, thus claiming that Spain was a cultural empire despite its loss of major overseas territories. The museum building and exhibitions highlighted sixteenth-century architecture and Catholicism, the two core symbols of Spanish imperialism. However, this museum already represented a shift in the history of overseas museums in Europe. When the Museum of America was established, Spain had had no large colonial empire for decades, except for Morocco and the Spanish Sahara. In fact, the exhibition replaced the real empire with a virtual visual one, which in the context of Franco's nationalist dictatorship claimed a role for Spain as a globally relevant great power justified by historical allegories (Lanzarote Guiral 2012: 307).

Most former European colonial museums changed, however, only during the decolonization process in the 1960s and 1970s. In this way, following the creation of the independent state of Congo, the Congo Museum in Brussels was renamed the Royal Museum of Central Africa. The neutral geographical term tried to transform the unpleasant associations with colonial rule into the achievements of objective scientific activity. Openly racist or discriminative references were removed and the museum, at large, tried to depict the area as an independent, Third World country (claiming the title 'Central Africa' for the former Belgian 
Congo alone), which pursued its own experiment with post-colonial modernization (Muteba 2003; Roger 2008: 85-9).

Remarkably, most museums in Western Europe devoted to the colonies remained largely untouched by these new ideas. Only one new museum devoted to colonial ethnography was founded in this period, namely the Overseas Museum in Portugal, which opened in 1975 (Bodenstein 2011d: 696). Although it was founded when the last Portuguese colony declared her independence, the formidable collection of South American, African and South-East Asian objects in the museum was not used to reflect on the country's colonial past (Dias 2001: 103). The scarcity of spectacular permanent exhibitions about the Third World suggests that it was difficult to understand what exactly was the particular meaning and relevance the objects of extra-European cultures. Although the colonial system collapsed only in the 1960s, many former colonies gained independence or began wars for liberation (Vietnam or Algeria) as the outcome of the Second World War. Such efforts were increasingly supported by the Soviet bloc, which saw a potential ally in the new states for a global anti-imperialist ideological, political or economic struggle. The international context led to the reconceptualizing of the 'Third World' as a major agent in global politics, which both the 'First' (the capitalist West) and the 'Second' (the socialist East) worlds needed to compete for. Colonial museums, therefore, found it increasingly difficult to represent cultures of the extra-European world as dependent on European progress or on the expansions of European nations.

A 'Third Worldist' museum, however, played a particularly important role in Yugoslavia. The Museum of African Art, on the one hand, presented an anticolonial approach, claiming that the quality of indigenous arts and crafts in Africa was evidence of the high level of social organization in these societies. On the other hand, anti-imperialism also took on an anti-Soviet meaning. African societies were represented in the museum as taking neither the road of Western capitalism nor that of Eastern socialism, but pursuing their own special ways. This was a virtue that official Yugoslav culture appreciated the most, because it was a position that justified the role which Yugoslav communist leaders wanted to play in global politics as leaders of non-aligned third way movements (Manojlović-Pintar and Ignjatović 2011: 799-801).

The collections related to extra-European societies began to obtain new relevance only after 1989, the end of the Cold War. Suddenly, they seemed to carry the history of a multicultural world and to give evidence of cultural and social diversity. The first free elections in East-Central Europe in 1989-90 and the end of the Soviet Union in 1991, which abruptly rendered Europe culturally and ethnically more diverse than it had previously been conceived to be, almost coincided with the 500th anniversary of Columbus's landing on the shores of America in 1992. A major global event to celebrate the anniversary was the World Exhibition in Sevilla, Spain, which linked together the idea of European civilization and the showcase of Spanish modernity as an integral part of that civilization (Lanzarote Guiral 2011: 869). The Columbian Spanish World Exhibition involved the renovation of the Museum of America, the 
institution that had for long been connected to the representation of Spanish culture in Latin America. The restoration of the museum facilities included the comprehensive interior reorganization of the exhibition. The Museum of America was transformed into illustrating the 'Meeting of Two Worlds', as the title suggested. By doing this, the exhibition represented Spanish colonizers and the indigenous colonized as two equal participants in a dialogue of cultures and effectively ignored the actual outcome of the encounter and the legacy of building a colonial empire. The museum aimed at discovering the origins of contemporary multiculturalism, ethnic diversity and the creative Spanish version of the American melting pot.

A similar shift occurred in Britain, when in 2004 the collections of the Department of Ethnography of the British Museum were returned to the museum's central building in Bloomsbury from London's Burlington Gardens, which had hosted the objects and the exhibitions based on them between 1970 and 1997 (Watson and Sawyer 2011: 119). At first sight, the move back and forth of ethnographic objects can be seen as the outcome of the expansion of the British Museum and the constant lack of appropriate space that it causes. However, the decision reflects the ideology of museum reorganization. The selection of ethnographic objects left the representation of ancient civilizations intact and thus implied a certain hierarchy between classical Greek-Roman cultures as the mainstream of the metanarrative of European modernity and extra-European cultures as strange and exotic marginal additions to that story.

However, the return of the ethnographic objects at the end of the 1990s represents the very opposite: it reintegrates extra-European (post-colonial) cultures into the mainstream of the narrative of civilization. This narrative has become a global history and claims that cultures of any kind are equally relevant for the interpretation. However, this was not only an exercise in relativism, but also a universalist act. The representation of global cultural variety enables maintaining the original identity of the British Museum as the guardian of the knowledge of the world (Jenkins 2012: 389-92). Besides, the move towards the representation of global cultural diversity makes great claims on the British national identity. Most Londonbased British national museums frame their exhibitions as international narratives. The National Maritime Museum, which was founded in 1934 and created a vast collection of naval and nautical equipment and objects, nowadays interprets its material as evidence of cross-Atlantic exchange and as part of the transnational history of global cultural translation and socio-economic relationships, instead of focusing on the glory of national imperial domination over the Atlantic (Sawyer 2012: 476-83). Contemporary national museums in Britain, hence, have transformed the empire into a global internationalized heritage. However, such a turn is not simply a deconstruction of nationalist identities, but also a reshaping of national identity. It advocates European values and international commitments as integral components of Britishness and Britain as a European and an international nation (Watson and Sawyer 2011: 120).

Former museums of the colonies have been reinterpreted as the meeting places of various cultures, both Western and non-Western. In the late 1990s, the Tropical 
Museum of the Netherlands, formerly the Colonial Museum, began to view its main mission as being to promote knowledge of the history and development of non-Western cultures and of the mutual impact of their contact with the Dutch people (Bodenstein 2011c: 608). Similarly to the British way, original ethnographic collections from the colonies help to reshape national identities of small European nations that used to be colonial powers. In 2000, the commemoration of the discovery of Brazil in the Overseas Museum of Portugal highlighted the encounter of European and indigenous cultures but remained inimical to reflections on the implications of colonization. Similarly, the National Maritime Museum seeks to offer a neutral technical knowledge about the development of ships and navies, focusing on aspects that concern the universal narrative of human civilization. The museum highlights the Golden Age of Portugal (fifteenth-sixteenth centuries), representing the period as one of technological progress and outstanding geographical discoveries, while it makes little attempt to interpret those centuries in the light of the history of colonization and destructive intervention (Bodenstein 2011d: 696, 703-4).

Throughout Europe, the transnational frame helped to reshape the original ethnography collections of colonial museums into post-colonial multiculturalist collections. The Royal Museum of Central Africa in Brussels has, since 2000, developed a programme of deconstructing the conventional frames of its colonial exhibition. The ExitMuseumCongo exhibition in 2000 was the first spectacular initiative in the new context. As its title suggests, the exhibition tried to dismantle the original colonial representation of the former Congo Museum by reflecting on the past of the museum itself. The museum staff created an exhibition that understood the genesis of knowledge about Africa as historically situated, as the outcome of a particular constellation of political objectives and scientific goals. The exhibition thus called attention to the contingencies of representation and to the diversity of the cultural perspectives that shape it (Bodenstein 2011a: 60-1).

In 2007, a freshly established French museum agency (the Agence France Museum) started to cooperate with North African and Chinese cultural authorities to set up new international museums in Abu Dhabi (Louvre Abu Dhabi) and Shanghai (Centre Pompidou Shanghai) (Bodenstein 2011b: 297). These programmes are meant to deliver museum expertise and financial and technical support for developing areas and to promote the values of intercultural tolerance and understanding. They represent French cultural policy as open to emerging multicultural interests and, in fact, also represent French culture itself as inherently multicultural and capable of dialogue with other cultural contexts. However, such programmes have ambiguous and even controversial implications in that cultural diversity is exported as a virtue of European French civilization. It is seen as the outcome of European French cultural tolerance, which is a perspective that does not ignore some component of teaching missions.

The recent reshaping of colonial narratives in terms of multicultural experiences affected national museums in countries whose colonies had been less extensive. In Germany, the attention of policy makers and social science research turned to the 
issue of migration as early as the 1990 s by the founding of a documentation centre. During the late 1990s, temporary exhibitions on the topic were installed, which became a regular element in Berlin museums in the 2000s (Aronsson and Bentz 2011: 341-2).

Empire has disappeared from manifest European definitions of the nation. Empires, however, remained as legacies of museum collections, as architecture and frames of interpreting the material, which now continues to shape the idea of the nation. The idea of empire has been translated into cultural diversity, dialogue and encounters and colonization into the history of technical civilization and geographical expeditions. The history of restoring Vasa, the Swedish naval ship, stands as a prototype of these processes (Widén 2011: 888). The ship, which was built as the flagship of a formidable Swedish imperial fleet, never had the opportunity to intervene in any armed conflicts, as it sunk on its first journey a few hundred metres from the harbour. Built as a threatening symbol of military power and imperial aggression, it now stands as the peaceful icon of technological creativity and skill. As a popular site of visit among foreign tourists, families and schoolchildren, it praises the harmless incompetency of Swedish imperialism.

The cases of the recasting of European colonial and imperial museums suggest that, in spite of the truly important shift in values, which today highlights diversity, tolerance and multiculturalism, some crucial layers in the framing of national identities remain untouched. The relationship to the extra-European world plays an immense role in the construction of ideas about nations in Europe. Such relationships construct peoples and countries in the 'Global South' as essentially different, whom Europeans can understand, tolerate and travel to and whose inhabitants can even immigrate into Europe. Through the truly important recognition of cultural diversity, many national museums of Europe maintain ethnicity, language and inherited cultural character as the means by which to identify nations.

\section{Memorial museums and museums of atrocities in Eastern Europe after 1989}

In national museums of the post-communist countries in Europe, the shift of values, which once used to support dictatorships to democratic legitimacy, often conceals an important continuity of ideas of an ethnically homogenous and closed nation. The most spectacular new national museums in the region, those that seek to commemorate the crimes of communism and to pay homage to the victims, seem to reinforce those myths of national martyrdom and historical essentialism that were often forged together in the last decades of the socialist dictatorships.

The House of Terror Museum in Budapest claims the authority of its representation of the past as an institution preserving and displaying collective memory. The House of Terror was inaugurated on 25 February 2002 as a non-governmental organization administered by a public foundation but benefited from an exceptional amount of taxpayers' money. It was claimed that this museum was built to commemorate the victims of dictatorial rule in the country. In reality, the museum 
creates a history of continuous occupations by German and Soviet military forces and the establishment of domestic fascist and communist dictatorships as a direct consequence of foreign intervention. On the one hand, the exhibition artificially isolates the short-lived Arrow Cross rule from the longer history of domestic antiSemitism and pro-fascist ideologies and politics. On the other, it depicts an entirely ahistorical picture of the socialist dictatorship, turning it into a period of uniform barbarity and violence seceding it from the history of oppression, and therefore from the broader social and cultural history of constructing, reshaping and dismantling the regime. Hungarian society, as a consequence, appears as an accidental victim of an ideological conflict homogenously resisting those alien intrusions (Frazon and Horváth 2002; Rév 2005: 278-90).

The House of Terror claims that its exhibitions use the model of previous new-media museums, particularly the Museum of Genocide Victims in Vilnius and the Yad Vashem in Jerusalem. Although the Budapest museum is an exception in its manifest ideological aim and abuse of historical representation, the idea that contemporary museums should profit more extensively from audio-visual and digital technologies to attract a larger number of visitors is a common conviction. However, while in most Holocaust exhibitions like the Yad Vashem or even in the Hungarian section of the permanent Auschwitz exhibition, computer technologies successfully represent the absence, the disappearance of human lives and the vulnerability that inherently concerns museum representations of the Holocaust (Rajk 2004), most new museums of communism and the Second World War manifest a radically different usage of digital media. In museums such as those in Budapest, Vilnius, the Museums of Occupation in Riga and Tallinn, the Jasenovac memorial museum in Croatia or even the Schindler Factory in Cracow, audio-visual media generally confuse the visitor, as in most cases the usage blurs the border between authentic historical evidence and replica and installation (Apor and Iordachi 2014).

The intentions behind such choices of representation may be quite different. In Budapest and in the Baltic republics, the new media representation is linked with the intention to blur the distinction between communism and Nazism in order to show these nations as innocent victims of both ideological dictatorships and, especially in the House of Terror, to isolate radical right-wing and fascist movements from their broader ideological context, particularly from conservative antiSemitism and nationalism. Such narratives of victimization and turning the experience of communist dictatorships into the conspiracy of alien forces are typical of post-communist (East-Central) European anti-communism. Other museums, such as the one in Sighet in Romania illustrate this point (Apor 2010). In Jasenovac the result of the new media display is that the innovative spectacle forgets explaining the actual historical origins and contexts of Ustasha terror and violence, thus making the proper understanding of the causes and effects of the events difficult. In Cracow, the new media installations are motivated by the intention to represent at the same time the history of the city, its Jewish population, its wartime experience and the Polish national narrative as the history of struggle for independence against both Germans and Russians. As a consequence, however, the 
abundance of information renders the proper following of any narrative structure difficult as well as the proper interpretation of what evidence was used for making such interpretations. Despite their differences, all such initiatives reflect a spectacular uncertainty concerning the possibilities and impossibilities of interpreting the events of recent history (Apor and Iordachi 2014).

In many ways, this is a pan-European fact. After 1989 many new museums started to emerge that claimed to be a new type of museum representing the moral obligation of commemoration and were thus devoted to the victims of the numerous mass persecutions occurring in the twentieth century. These new museums devoted to the Holocaust, communist terror, war atrocities or ethnic cleansing usually refer to themselves as memorial museums that preserve the memory of the victims and pursue the task of memory institutions, like constructing a collective memory for various social or political communities (Williams 2007: 3-25; 2012: 92-106).

The popularity of memorial museums is linked to the emerging travel industry across Europe. The post-war economic stabilization, the solid rise of the standard of living and the gradual cultural opening up of societies that began in Western Europe in the late 1960s were soon followed by comparable developments in Eastern Europe. As a consequence, tourism has become a mass phenomenon. Tourism, the travel to somewhere else per se, seeks precisely the authentic experience of being somewhere else. Museums of communism in post-communist Eastern Europe have typically two types of audiences: local school groups and Western visitors who have no personal memories of communism. Providing the chilling experience of dictatorship, which seems so different from current democratic societies, the museums of communism can successfully meet such desire for consuming difference. As a matter of fact, museums and memorial exhibitions of mass death, executions and war sites are extremely popular goals of contemporary museum goers. Concentration camp exhibitions, World War I sites on the Western front or the cemeteries and memorials of D-Day in Normandy or museums of the resistance in France are highlights of any guidebooks for visitors in the countries in question (Poulot 2012: 535-6). Such tourisms of war and violence reveal how close the practices of contemporary tourists looking for the authentic experiences of invading foreign lands are to the first professional travel groups in history, namely soldiers (Diller and Scofidio 1994: 19-28).

\section{Ethnic multiculturalism, multicultural ethnicity}

Tourism and the travel industry intersected with the broader emergence of museums that offer the authentic experience of the different and the particular throughout Europe (Riegel 1996: 83-8). The end of the Cold War suddenly rendered most certainties that framed historical narratives and national identities and, thus, national museums in Europe largely irrelevant. Cold War counterimages and East-West conflicting ideological identities explained little about the emerging post-Cold War political and cultural conditions, which, at least 
originally, seemed to focus on common European components and entangled histories. However, the frames of a newly constructed European identity were only one element that reshaped national museums throughout the continent. Parallel to an increasing Europeanization, national museums were also at the forefront of recreating national identities and particularities (van Hasselt 2010: 313-22; Clarke 2012: 175-7; Watson 2012: 557-60), in many ways as a reaction to previous transnational cultural identities promoted both by the socialist East, which emphasized international anti-capitalist solidarity, and by the capitalist West, which highlighted the common Western European traditions as a protection against the threat of Eastern communism.

The re-ethnicization of national identities seems a pan-European current that affects similarly both former Eastern and Western Europe. In countries of the former Eastern bloc this is, on the one hand, a reaction against previous attempts at Sovietizing culture, which was generally seen as non-national. On the other hand, the reconstruction of nationalist cultures is linked to the broader development of ethnic revival, in other words, the re-emergence of ethnicity as the core idea of national identities in the context of uniform cultural references that are globally available. This process is in many ways linked to the emerging post-colonial identities, which highlight cultural difference and the right to challenge mainstream European elite universalist values. Such reappraisals of conventional European frames of identity are multifaceted, springing from former colonial intellectuals, former Soviet bloc cultures as well as Western European minorities and regional politics (Shelby 2010: 429-40; Kirwan 2010: 449-50).

All these were firmly linked to the emergence of the concept and practice of cultural heritage, which since the 1970s has powerfully framed the role of museums in Europe. Arguably, the success of the notion of cultural heritage has been related to the growing criticism of the conventional intellectual focus on large processes and big units such as the state or the nation and to the scepticism towards the possibility of making a reliable forecast of future social, economic or political tendencies. Such criticism has had two major consequences. First, it has become broadly endorsed that local communities, sub-cultural groups and individuals have the right and ability to develop their own identities. In turn, making such identities into attractive goals of cultural tourism receives support from various state and regional authorities. Second, the unpredictable future has been largely replaced by the certainties of the past, which has been understood as a collection of endangered traditions that are worth being fully preserved (Lowenthal 1985: 4-40; 1998: 1-6; Ury 1996: 52). Museums, thus, collect any 'identities'. Nonetheless, they also detach their world from the European, modern Western museum citizen's present: they either display its past or its geographical external in the shape of overseas or local exotic cultures.

The idea that there was a need to regenerate traditional ethnic cultures was very powerful in post-communist East-Central Europe, even though various geopolitical regions differed in some components. In the Baltics, whose three new republics of Estonia, Latvia and Lithuania used to be part of the Soviet Union, the 
programme of recreating national identities was normally considered as a response against previous Sovietization, which was frequently equalled with Russification and invoked strong anti-Russian sentiments in many citizens, particularly in the early post-communist period. These conditions had a very powerful impact in Estonia and Latvia, where large ethnic Russian groups were moved in during the Soviet period, but even affected Lithuania, although the country hosted considerably fewer Russian immigrants than the two other Baltic republics.

The Estonian History Museum (a name in use since 1989) displays a national history of Estonians identified mostly in terms of ethnicity. In a similar manner, the Estonian National Museum exhibits mostly traditional folk culture reflecting its holdings consisting of ethnographic objects. Mirroring the general cultural discourse on a 'second national awakening' following 1989, the new permanent 1994 exhibition identified the conditions of being 'Estonian' in spiritual and cultural terms. The exhibition 'Estonia: Land, People, Culture' itself was close to an imitation of an open-air museum in its attempt to capture the totality of national ways of life and values by displaying artefacts of national spirit beyond conventional museum objects of everyday folkways (Kuutma 2011: 242; Rummel et al. 2010: 328).

Open-air museums, creating the unity of material culture, architecture and landscape and possibly evoking the idea of spiritual heritage associated with these cultural objects, became on the whole very popular. The Lithuanian Ethnographic Museum of Everyday Life near Kaunas made tangible the ideas of ethnographers and other public intellectuals who associated national heritage with a set of practices, rituals and ways of life apart from built and material culture. The exhibition, which presented a village setting emphasizing the uniqueness and particularity of architecture in Lithuanian villages, was expanded after 1990. These extensions, however, continued the narrative of national identity by adding reconstructions of buildings used by Lithuanian deportees to Siberia or by Lithuanian anti-communist partisans (Rindzevičiūtė 2011: 546).

The complexities of post-colonial national identities, which are often cast in ethnic terms, cultural heritage and regionalism are particularly apparent in the UK, France and Spain, where the legacies of global empire, intensive migration and domestic regional (Scottish, Welsh, Basque or Catalan) nationalisms sharply influence cultural policies. Since the mid-1980s, museum policies have typically responded to such challenges by regionalizing and decentralizing the institutional infrastructure and simultaneously stressing multicultural heritage at home. The network of national museums in Britain, as in most European states, is concentrated in the capital, London. In 1986, however, National Museums Liverpool was founded. Liverpool was a first major attempt to transfer cultural institutions of national significance to a provincial urban centre. The initiative was part of a broader programme to regenerate a declining former industrial urban centre by means of culture, which, at the end, also contributed to the confirmation of regional identities, making Liverpool, the former major harbour of the UK, into a cultural and museum centre competing in many ways even with London (Watson and Sawyer 2011: 112). Similarly, regional identities have been spectacularly institutionalized in Spain in the decades following 
Franco's death. The administration of the autonomous Basque Country founded the Museum of the Basque Country and the Museum of Basque Nationalism in 1991 and 1993, respectively (Roigé i Ventura and Arrieta Urtizberea 2010). In 1996, the Museum of History of Catalonia was established in Barcelona. The museum, on the one hand, confirms regional-territorial identity by projecting backwards the Catalan (autonomous) state in time. On the other hand, it encourages thinking about national identity in ethnic terms: the exhibition consequently takes all currently Catalan-speaking territories as its obvious subject (Hernández Cardona 1996; Vinyes Ribas 2000; Lanzarote Guiral 2011: 870-1).

By the late 1990s, cultural policies framing national museums increasingly encouraged the multiplication of cultural identities. The UK was clearly at the forefront of such initiatives. National museums in London began to stress the multifaceted nature of British society and culture by the late 1990s. They highlighted the history of ethnic and cultural minorities in Britain and stressed their role in and contribution to the building of the British nation. The intention is to create frames for a tolerant approach towards minority cultures and groups. However, the cultural policy has also encouraged the multiplication of separate cultural identities based on ethnicity, cultural priorities, language or gender (Watson and Sawyer 2011: 100). The recent cultural policy in France illustrates similar tendencies. Recent developments in national museums in Paris, most importantly the Islamic culture exhibition in 2003 in the Louvre and the new Musée Quai Branly, established in 2006 and dedicated to extra-European art, emphasize the multivalent state of global culture and the importance of cultural dialogue (Bodenstein 2011b: 305-6). Most recently, the inauguration of the Marseille-based Musée des Civilisations de l'Europe et de la Méditerrannée (MuCEM) seems to illustrate similar concerns (Mazé et al. 2013).

Besides nation-states, paradoxically, the cultural policy of the European Union also contributes to the emergence of ethnic particularism and an attitude to museums as being mainly sites of preserving a community heritage (Höglund 2012: 158-83). Since the early 1990s and, increasingly, since the Eastern enlargement in 2004, the institutions of the European Union have highlighted culture as a major potential vehicle for European cohesion. The cultural policy of the EU is, however, double-faced. On the one hand, it stresses the need to develop pan-European identities and solidarities. On the other hand, it endorses the protection of cultural diversity. Cultural diversity is understood mainly in its two shapes. First, the preservation of nation-specific assets as it is evidenced by the regulation of protecting national treasures, which are normally understood as the representations of old cultural traditions. Second, the EU supports regional autonomies and cultural identities, mostly because those are seen to possibly transcend nation-states, the greatest rivals of EU governance in decision-making. Regional identities are also supported in some of the member states. It is true particularly in Spain, because of the need to contain Basque and Catalan separatism, and in Germany, where regional and European identities seem a way to transcend the problematic issue of the German national identity (Fulbrook 1999). 


\section{Conclusions}

The chapter has argued that national museums are representations of a universal history of civilization and as such shifted to represent particular community identities during the twentieth century. One major factor of this transformation was the growing sense of loss and guilt that contributed to a set of changes in the outlook and ideology of national museums. Following the First World War, all European states and elites had to confront the rearrangement of territories and regions in Europe, which was a crucial cause of the 'nationalization' of universal museum languages. National museums in Europe are inherently linked to statehood: either as representatives of state sovereignty as many former dynastic collections were or as substitutes of independent statehood as were many museums connected to small nations living within various composite states or dispersed in more than one state.

The Second World War triggered further transformations: the emergence of 'socialist nations' in the context of the Cold War and the reshaping of colonial museums in the wake of decolonization. National museums in Eastern Europe that tried to represent their 'socialist nations' often reproduced traditional understandings of the ethnic nation even if they integrated the peasantry and urban lower classes into the concept more than their pre-1945 counterparts had done. Colonial museums in Western Europe, in turn, reinterpreted classical racist and Eurocentric exhibitions in terms of a multi-cultural dialogue. However, the language of 'multiculturalism' has proved to be effective also in covering the aggressive nature of European imperialism. The cultural sensitivity to loss and guilt has since the 1970s been significantly intersected with the idea of cultural heritage and mass tourism. A tourism of war and violence, on the one hand, meets the mushrooming memorial museums all over Europe, museums of communism in Eastern Europe, war sites in Western Europe and concentration camps continent-wide. The idea of heritage, on the other hand, which involves the right of communities to define their own identities and the imperative to preserve the remnants of the past, meets the panEuropean ethnic revival and the re-ethnicization of national identities.

National museums are often considered by elites and sometimes also by themselves as shorthand for national identities. Elites shaping the visual outlook of central museum exhibitions usually reflect real or imagined audience expectations and therefore produce museum displays in ways that they think would or should suit museum-goers' needs and wishes. As a consequence, national museums do indeed represent the changing notions and negotiations about national identity to the broader national community and the world. However, national museums are not mere representations of constructed national identities. On the one hand, they are not inimical to transnational processes. In fact, such institutions of making the values and achievements of national communities tangible have always looked carefully and often jealously to their equivalents beyond national borders. On the other hand, they have a history as institutions and a history of collections, in particular, framing the ways in which they can produce exhibitions. As a consequence, such exhibitions are not always the mere reflections of elite intentions; in fact, they 
are the outcomes of complex interactions among policy makers, museum professionals, academics, audiences and their own collections.

\section{References}

Apor, P. (2010) 'Eurocommunism: commemorating communism in contemporary Eastern Europe', in M. Pakier and B. Strath (eds.) A European Memory? Contested Histories and Politics of Remembrance, Oxford: Berghahn, 233-46.

- (2011a) 'National museums in the Czech Republic', in P. Aronsson and G. Elgenius (eds.) Building National Museums in Europe 1750-2010, Eunamus Report No 1, Linköping: Linköping University Electronic Press, 203-12.

- (2011b) 'National museums in Hungary', in P. Aronsson and G. Elgenius (eds.) Building National Museums in Europe 1750-2010, Eunamus Report No 1, Linköping: Linköping University Electronic Press, 401-24.

Apor, P. and Iordachi, C. (eds.) (2014) Re-visualizing the Recent Past: Museums of Communism and Recent History in Post-Communist Eastern Europe, unpublished manuscript.

Aronsson, P. and Bentz, E. (2011) 'National museums in Germany: anchoring competing communities', in P. Aronsson and G. Elgenius (eds.) Building National Museums in Europe 1750-2010, Eunamus Report No 1, Linköping: Linköping University Electronic Press, $327-62$.

Badica, S. (2010) 'Same exhibitions, different labels? Romanian national museums and the fall of communism', in S.J. Knell, P. Aronsson, A. Amundsen, et al. (eds.) National Museums: New Studies from Around the World, London and New York: Routledge, 272-89.

- (2011) 'National museums in Romania', in P. Aronsson and G. Elgenius (eds.) Building National Museums in Europe 1750-2010, Eunamus Report No 1, Linköping: Linköping University Electronic Press, 713-31.

Barcellini, C. (2010) Le Musée de l'Armée et la fabrique de la Nation. Histoire militaire, histoire nationale et enjeux muséographiques, Paris: l'Harmattan.

Barnes, A. J. (2010) 'Exhibiting China in London', in S.J. Knell, P. Aronsson, A. Amundsen, et al. (eds.) National Museums: New Studies from Around the World, London and New York: Routledge, 386-99.

Behrends, J.C. (2009) 'Nation and empire: dilemmas of legitimacy during Stalinism in Poland (1941-56),' Nationalities Papers, 37: 443-66.

Bennett, T. (1995) The Birth of the Museum: History, Theory, Politics, London and New York: Routledge.

Bentz, E. and Raffler, M. (2011) 'National museums in Austria', in P. Aronsson and G. Elgenius (eds.) Building National Museums in Europe 1750-2010, Eunamus Report No 1, Linköping: Linköping University Electronic Press, 21-46.

Bodenstein, F. (2011a) 'National museums in Belgium', in P. Aronsson and G. Elgenius (eds.) Building National Museums in Europe 1750-2010, Eunamus Report No 1, Linköping: Linköping University Electronic Press, 47-68.

(2011b) 'National museums in France', in P. Aronsson and G. Elgenius (eds.) Building National Museums in Europe 1750-2010, Eunamus Report No 1, Linköping: Linköping University Electronic Press, 289-326.

-(2011c) 'National museums in the Netherlands', in P. Aronsson and G. Elgenius (eds.) Building National Museums in Europe 1750-2010, Eunamus Report No 1, Linköping: Linköping University Electronic Press, 595-623.

- (2011d) 'National museums in Portugal', in P. Aronsson and G. Elgenius (eds.) Building National Museums in Europe 1750-2010, Eunamus Report No 1, Linköping: Linköping University Electronic Press, 689-712.

Boia, L. (2001) History and Myth in Romanian Consciousness, Budapest: CEU Press.

Brandenberger, D. (2002) National Bolshevism: Stalinist Mass Culture and the Formation of Modern Russian National Identity, 1931-1956, Cambridge, MA, and London: Harvard University Press. 
Catapoti, D. (2012) 'A nationalist palimpsest: authoring the history of the Greek nation through alternative museum narratives', in D. Poulot, F. Bodenstein and J.M. Lanzarote Guiral (eds.) Great Narratives of the Past: Traditions and Revisions in National Museums, Eunamus Report No 4, Linköping: Linköping University Electronic Press, 133-68.

Clarke, A. (2012) 'From royal to national: the changing face of the National Museum of Scotland', in D. Poulot, F. Bodenstein and J.M. Lanzarote Guiral (eds.) Great Narratives of the Past: Traditions and Revisions in National Museums, Eunamus Report No 4, Linköping: Linköping University Electronic Press, 169-78.

Condell, D. (2002) 'The history and role of the Imperial War Museum', in B. Korte and R. Schneider (eds.) War and the Cultural Construction of Identities in Britain, Amsterdam: Rodopi.

Cornelis, S. (2000) 'Le musée du Congo belge, vitrine de l'action coloniale (1910-30)', in D. Taffin (ed.) Du musée colonial au musée des cultures du monde, Paris: Maisonneuve et Larose, 71-85.

Dias, N. (2001) “"Does anthropology need museums?” Teaching ethnographic museology in Portugal thirty years later', in M. Bouquet (ed.) Academic Anthropology and the Museum: Back to the Future, Oxford: Berghahn Books, 92-104.

Diller, E. and Scofidio, R. (1994) Visite aux armées: Tourismes de guerre/Back to the Front: Tourisms of War, F.Z.A.C. Basse-Normandie.

Domańska, E. (2000) '(Re)creative myths and constructed history: the case of Poland', in B. Stråth (ed.) Myth and Memory in the Construction of Community: Historical Patterns in Europe and Beyond, Brussels: PIE - Peter Lang, 249-62.

Eilersten, L. (2012) 'Freedom loving northerners: Norwegian independency as narrated in three national museums', in D. Poulot, F. Bodenstein and J.M. Lanzarote Guiral (eds.) Great Narratives of the Past: Traditions and Revisions in National Museums, Eunamus Report No 4, Linköping: Linköping University Electronic Press, 179-216.

Fabian, J. (1983) Time and the Other: How Anthropology Makes its Object, New York: Columbia University Press.

Fejős, I. (1965) 'A Magyar Nemzeti Múzeum története 1848-1944 [The History of the Hungarian National Museum 1848-1944]', Folia Archaeologica, 17: 285-301.

Fewster, D. (2006) Visions of the Past Glory: Nationalism and the Construction of Early Finnish History, Studia Fennica, Historica 11, Helsinki: Finnish Literature Society.

Fogu, C. (2003) The Historic Imaginary: Politics of History in Fascist Italy, Toronto, Buffalo and London: University of Toronto Press.

Frazon, Zs. and Horváth, K. Zs. (2002) 'A megsértett Magyarország. A Terror Háza mint tárgybemutatás, emlékmū és politikai rítus [The Offended Hungary: The House of Terror as a Demonstration of Objects, Memorial and Political Rite]', Regio, 13: 303-47.

Fulbrook, M. (1999) German National Identity after the Holocaust, Cambridge: Polity Press.

Gazi, A. (2011) 'National museums in Greece: history, ideology, narratives', in P. Aronsson and G. Elgenius (eds.) Building National Museums in Europe 1750-2010, Eunamus Report No 1, Linköping: Linköping University Electronic Press, 363-99.

Hernández Cardona, F. X. (1996) 'Museu d'História de Catalunya: criteris histórics i museológics,' Afers: fulls de recerca i pensament, 11(23): 367-73.

Hillström, M. (2012) 'Nordiska Museet and Skansen: Display of Floating Nationalities', in D. Poulot, F. Bodenstein and J.M. Lanzarote Guiral (eds.) Great Narratives of the Past: Traditions and Revisions in National Museums, Eunamus Report No 4, Linköping: Linköping University Electronic Press, 33-48.

Hobsbawm, E. (1995) The Age of Extremes: The Short Twentieth Century, 1914-1991, London: Michael Joseph.

Höglund, M. (2012) 'European Union approaches to museums 1993-2010', in L. Eilertsen and A. Amundsen (eds.) Museum Policies in Europe 1990-2010: Negotiating Professional and Political Utopia, Eunamus Report No 3, Linköping: Linköping University Electronic Press, 157-88.

Hudek, A. (2011) 'National museums in Slovakia: nation building strategies in a frequently changing environment', in P. Aronsson and G. Elgenius (eds.) Building National Museums 
in Europe 1750-2010, Eunamus Report No 1, Linköping: Linköping University Electronic Press, 817-46.

Jankevičiūtè, G. (2010) 'Constructing national identity: the image of the medieval Grand Duchy of Lithuania in Lithuanian art from the 1920s to the 1990s', Central Europe, 8(2): 158-80.

Jenkins, T. (2012) 'Inverting the nation at the British Museum', in D. Poulot, F. Bodenstein and J.M. Lanzarote Guiral (eds.) Great Narratives of the Past: Traditions and Revisions in National Museums, Eunamus Report No 4, Linköping: Linköping University Electronic Press, 387-94.

Kammel, F.M. (2012) 'The Germanisches Nationalmuseum in Nuremberg: the cultural memory of a nation without national borders', in D. Poulot, F. Bodenstein and J.M. Lanzarote Guiral (eds.) Great Narratives of the Past: Traditions and Revisions in National Museums, Eunamus Report No 4, Linköping: Linköping University Electronic Press, 217-28.

Karp, I. and Lavine, S.D. (eds.) (1991) Exhibiting Cultures: The Poetics and Politics of Museum Display, Washington and London: Smithsonian Institute Press.

Kemenczei, Á. (1996) ““ ... megmentettem a Nemzeti Múzeumot ...” Egy amerikai tábornok 1919-ben a Magyar Nemzeti Múzeumért' [““ ... I saved the National Museum ..." An American General for the Hungarian National Museum]', Magyar Múzeumok, 2: 21-4.

Kencis, T. and Kuutma, K. (2011) 'National museums in Latvia', in P. Aronsson and G. Elgenius (eds.) Building National Museums in Europe 1750-2010, Eunamus Report No 1, Linköping: Linköping University Electronic Press, 497-519.

Kirwan, A. (2010) 'Postcolonialism, ethnicity and the National Museum of Ireland', in S.J. Knell, P. Aronsson, A. Amundsen, et al. (eds.) National Museums: New Studies from Around the World, London and New York: Routledge, 443-52.

Kopeček, M. (2012) 'Historical studies of nation-building and the concept of socialist patriotism in East Central Europe 1956-70' in P. Kolar and M. Reznik (eds.) Historische Nationsforschung im geteilten Europa 1945-1989, Cologne: SH Verlag, 121-36.

Köksal, A.H. (2010) 'National art museums and the modernization of Turkey', in S.J. Knell, P. Aronsson, A. Amundsen et al. (eds.) National Museums: New Studies from Around the World, London and New York: Routledge, 163-79.

Kuutma, K. (2011) 'National Museums in Estonia', in P. Aronsson and G. Elgenius (eds.) Building National Museums in Europe 1750-2010, Eunamus Report No 1, Linköping: Linköping University Electronic Press, 231-59.

Lanzarote Guiral, J.M. (2011) 'National museums in Spain: a history of crown, church and people', in P. Aronsson and G. Elgenius (eds.) Building National Museums in Europe 17502010, Eunamus Report No 1, Linköping: Linköping University Electronic Press, 847-80. (2012) 'Rediscovering the Americas: the making of Latin American archaeological collections in Spanish national museums', in D. Poulot, F. Bodenstein and J.M. Lanzarote Guiral (eds.) Great Narratives of the Past: Traditions and Revisions in National Museums, Eunamus Report No 4, Linköping: Linköping University Electronic Press, 297-315.

Legêne, S. (2000) 'Identité national et "cultures autres": le Musée colonial comme monde á part aux Pays-Bas', in D. Taffin (ed.) Du musée colonial au musée des cultures du monde, Paris: Maisonneuve et Larose, 87-102.

Lepenies, W. (2006) The Seduction of Culture in German History, Princeton: Princeton University Press.

Loumpet-Galitzine, A. (2012) 'An unattainable consensus? National museums and great narratives in French-speaking Africa', in D. Poulot, F. Bodenstein and J.M. Lanzarote Guiral (eds.) Great Narratives of the Past: Traditions and Revisions in National Museums, Eunamus Report No 4, Linköping: Linköping University Electronic Press, 617-34.

Lowenthal, D. (1985) The Past is a Foreign Country, Cambridge: Cambridge University Press. (1998) The Heritage Crusade and the Spoils of History, Cambridge: Cambridge University Press. 
Manojlović-Pintar, O. and Ignjatović, A. (2011) 'National museums in Serbia: a story of intertwined identities', in P. Aronsson and G. Elgenius (eds.) Building National Museums in Europe 1750-2010, Eunamus Report No 1, Linköping: Linköping University Electronic Press, 779-815.

Masłowska, A. (2002) Kronika wystaw Muzeum Narodowego w Warszawie T.1 1862-1962, T.2 1963-1982 [Chronicle of Exhibitions at the National Museum in Warsaw v.1 18621962, v.2 1963-82], Warszawa: Wydawnictwo Muzeum Narodowego w Warszawie.

Mason, R. (2007) Museums, Nations, Identities: Wales and Its National Museums, Cardiff: University of Wales Press.

Mattl, S. (1995) 'Kulturpolitik', in E. Tálos, H. Dachs, E. Hanisch and H. Stekl (eds.) Handbuch des politischen Systems Österreichs. Erste Republik 1918-1933, Vienna: MANZ Verlag: 618-31.

Mazan, K. (2011) 'National museums in Poland', in P. Aronsson and G. Elgenius (eds.) Building National Museums in Europe 1750-2010, Eunamus Report No 1, Linköping: Linköping University Electronic Press, 667-87.

Mazé, C., Poulard, F. and Ventura, C. (eds.) (2013) Les musées d'ethnologie. Culture, politique et changement institutional, Charenton-Le-Pont: Laboratoire d'anthropologie et d'histoire de l'institution de la culture.

Merridale, C. (1999) 'War, death, and remembrance in Soviet Russia' in J. Winter and E. Sivan (eds.) War and Remembrance in the Twentieth Century, Cambridge: Cambridge University Press, 61-83.

Mevius, M. (2005) Agents of Moscow: The Hungarian Communist Party and the Origins of Socialist Patriotism 1941-1953, Oxford: Oxford University Press.

-(2009) 'Reappraising Communism and Nationalism', Nationalities Papers, 37: 377-400.

Mruškovič, Š., Darulová, J. and Kollár, Š. (2005) Muzejníctvo, muzeológia a kultúrne dedičstvo, Banská Bystrica: Univerzita Mateja Bela.

Muteba, J. (2003) 'The ghost of Leopold II: the Belgian Royal Museum of Central Africa and its dusty colonial exhibition', Research in African Literatures, 34: 58-84.

Nothnagle, A.L. (1999) Building the East German Myth: Historical Mythology and Youth Propaganda in the German Democratic Republic, 1945-1989, Ann Arbor: University of Michigan Press.

Oulebsir, N. (2004) Les usages du patrimoine. Monuments, musées et politique coloniale en Algérie (1830-1930), Paris: Éditions de la Maison des sciences de l'homme.

Penny III, H. G. (1995) 'The Museum für Deutsche Geschichte and German national identity', Central European History, 28(3): 343-72.

Petkova-Campbell, G. (2012) 'Uses and exploitation of history: official history, propaganda and mythmaking in Bulgarian museums', in D. Poulot, F. Bodenstein and J.M. Lanzarote Guiral (eds.) Great Narratives of the Past: Traditions and Revisions in National Museums, Eunamus Report No 4, Linköping: Linköping University Electronic Press, 69-77.

Petrescu, D. (2009) 'Building the nation, instrumentalizing nationalism: revisiting Romanian national-communism, 1956-89', Nationalities Papers, 37: 523-44.

Pettersson, S. (2010) 'Producing an art history of the nation: the origins of the Finnish National Gallery', in S.J. Knell, P. Aronsson, A. Amundsen, et al. (eds.) National Museums: New Studies from Around the World, London and New York: Routledge, 138-50.

- (2011) 'National museums in Finland', in P. Aronsson and G. Elgenius (eds.) Building National Museums in Europe 1750-2010, Eunamus Report No 1, Linköping: Linköping University Electronic Press, 261-88.

Pohrib, I. (2012) 'Tradition and ethnographic display: defining the national specificity at the National Art Museum in Romania (1906-37)', in D. Poulot, F. Bodenstein and J.M. Lanzarote Guiral (eds.) Great Narratives of the Past: Traditions and Revisions in National Museums, Eunamus Report No 4, Linköping: Linköping University Electronic Press, 317-29.

Poulot, D. (2012) 'Museums and history in contemporary France', in D. Poulot, F. Bodenstein, and J.M. Lanzarote Guiral (eds.) Great Narratives of the Past: Traditions and Revisions 
in National Museums, Eunamus Report No 4, Linköping: Linköping University Electronic Press, 531-44.

Prösler, M. (1996) 'Museums and globalization' in S. Macdonald and G. Fyfe (eds.) Theorizing Museums: Representation, Identity and Diversity in a Changing World, Oxford: Blackwell - The Sociological Review, 21-44.

Rajk, L. (2004) 'The betrayed citizen', www.rajk.hu/auschwen.html (accessed 5 April 2013).

Reinius, L.G. (2010) 'Exhibiting the Congo in Stockholm', in S.J. Knell, P. Aronsson, A. Amundsen et al. (eds.) National Museums: New Studies from Around the World, London and New York: Routledge, 400-17.

Rév, I. (2005) Retroactive Justice: Prehistory of Post-Communism, Stanford: Stanford University Press.

Riegel, H. (1996) 'Into the heart of irony: ethnographic exhibitions and the politics of difference', in S. Macdonald and G. Fyfe (eds.) Theorizing Museums: Representation, Identity and Diversity in a Changing World, Oxford: Blackwell - The Sociological Review, 83-104.

Rindzevičiūte, E. (2010) 'Imagining the Grand Duchy of Lithuania: the politics and economics of the rebuilding of Trakai Castle and the "Palace of Sovereigns" in Vilnius', Central Europe, 8(2): 180-202.

-(2011) 'National museums in Lithuania: a story of state building (1855-2010)', in P. Aronsson and G. Elgenius (eds.) Building National Museums in Europe 1750-2010, Eunamus Report No 1, Linköping: Linköping University Electronic Press, 521-52.

Roigé i Ventura, X. and Arrieta Urtizberea, I. (2010) 'Construcción de identidades en los museos de Cataluña y el País Vasco: entre lo local, nacional y global', Pasos: Revista de turismo y patrimonio cultural, 8(4): 539-53.

Roger, A. (2008) 'Le rôle complexe des supports matériels de la mémoire nationale. Le Musée Royal de l'Afrique centrale, ancien Musée du Congo belge, et la mémoire belge du fait colonial', in C. Hähnel-Mesnard (ed.) Culture et mémoire: représentations contemporaines de la mémoire dans les espaces mémoriels, les arts du visuel, la littérature et le theatre, Palaiseau: Éditions Ecole Polytechnique, 85-92.

Rummel, P., Tatsi, T. and Prunlmann-Vengerfeldt, P. (2010) 'Who authors the nation?', in S.J. Knell, P. Aronsson, A. Amundsen et al. (eds.) National Museums: New Studies from Around the World, London and New York: Routledge, 325-38.

Savino, M. (2012) 'Narrating the "new" history: museums in the construction of the Turkish Republic', in D. Poulot, F. Bodenstein and J.M. Lanzarote Guiral (eds.) Great Narratives of the Past: Traditions and Revisions in National Museums, Eunamus Report No 4, Linköping: Linköping University Electronic Press, 253-64.

Sawyer, A. (2011) 'National museums in the Republic of Ireland', in P. Aronsson and G. Elgenius (eds.) Building National Museums in Europe 1750-2010, Eunamus Report No 1, Linköping: Linköping University Electronic Press, 435-60.

(2012) 'Maritime master narratives in European national museums', in D. Poulot, F. Bodenstein and J.M. Lanzarote Guiral (eds.) Great Narratives of the Past: Traditions and Revisions in National Museums, Eunamus Report No 4, Linköping: Linköping University Electronic Press, 467-85.

Sharenkova, R. (2010) 'After the fall of the Berlin Wall: nationalism and multiculturalism at the Bulgarian National Ethnographic Museum', in S.J. Knell, P. Aronsson, A. Amundsen et al. (eds.) National Museums: New Studies from Around the World, London and New York: Routledge, 418-28.

Shaw, W.K. (2011) 'National museums in the Republic of Turkey: Palimpsests within a centralized state', in P. Aronsson and G. Elgenius (eds.) Building National Museums in Europe 1750-2010, Eunamus Report No 1, Linköping: Linköping University Electronic Press, 925-51.

Shelby, K.D. (2010) 'The Ijzertoren Memorial Museum: a Flemish national museum?', in S.J. Knell, P. Aronsson, A. Amundsen et al. (eds.) National Museums: New Studies from Around the World, London and New York: Routledge, 429-42. 
Stone, M.S. (1998) The Patron State: Culture and Politics in Fascist Italy, Princeton: Princeton University Press.

Todorova, M. (1997) Imagining the Balkans, New York: Oxford University Press.

Troilo, S. (2011) 'National museums in Italy: a matter of multifaceted identity', in P. Aronsson and G. Elgenius (eds.) Building National Museums in Europe 1750-2010, Eunamus Report No 1, Linköping: Linköping University Electronic Press, 461-95.

Tumarkin, N. (1994) The Living and the Dead: The Rise and Fall of the Cult of World War II in Russia, New York: Basic Books.

Ury, J. (1996) 'How Societies Remember the Past', in S. Macdonald and G. Fyfe (eds.) Theorizing Museums: Representation, Identity and Diversity in a Changing World, Oxford: Blackwell - The Sociological Review, 45-65.

van Hasselt, G. (2010) 'The Dutch National Historical Museum: a national museum for the twenty-first century', in S.J. Knell, P. Aronsson, A. Amundsen et al. (eds.) National Museums: New Studies from Around the World, London and New York: Routledge, 313-24.

Vinyes Ribas, R. (2000) 'Un conflicte de memories: el Museu d'História de Catalunya,' L'Avenç: Revista de história i cultura 247: 34-7.

Vukov, N. (2011) 'National museums in Bulgaria: a story of identity politics and uses of the past', in P. Aronsson and G. Elgenius (eds.) Building National Museums in Europe 17502010, Eunamus Report No 1, Linköping: Linköping University Electronic Press, 133-49.

(2012) 'Ethnoscripts and nationographies: imagining nations within ethnographic museums in South Central and Eastern Europe', in D. Poulot, F. Bodenstein and J.M. Lanzarote Guiral (eds.) Great Narratives of the Past: Traditions and Revisions in National Museums, Eunamus Report No 4, Linköping: Linköping University Electronic Press, 331-43.

Wandycz, P.S. (1993) The Price of Freedom: A History of East Central Europe from the Middle Ages to the Present, London: Routledge.

Watson, S. (2012) 'Museums and the origins of nations', in D. Poulot, F. Bodenstein and J.M. Lanzarote Guiral (eds.) Great Narratives of the Past: Traditions and Revisions in National Museums, Eunamus Report No 4, Linköping: Linköping University Electronic Press, 545-65.

Watson, S. and Sawyer, A. (2011) 'National museums in Britain', in P. Aronsson and G. Elgenius (eds.) Building National Museums in Europe 1750-2010, Eunamus Report No 1, Linköping: Linköping University Electronic Press, 99-132.

Westrate, J.-L. (1961) European Military Museums: A Survey of Their Philosophy, Facilities, Programs and Management, Washington: Smithsonian Institution.

Widén, P. (2011) 'National museums in Sweden: a history of denied empire and a neutral state', in P. Aronsson and G. Elgenius (eds.) Building National Museums in Europe 1750-2010, Eunamus Report No 1, Linköping: Linköping University Electronic Press, 881-902.

Williams, P. (2007) Memorial Museums: The Global Rush to Commemorate Atrocities, New York and Oxford: Berg.

(2012) 'Treading difficult ground: the effort to establish Russia's first national Gulag museum', in D. Poulot, J.M. Lanzarote Guiral and F. Bodenstein (eds.) National Museums and the Negotiation of Difficult Pasts, Eunamus Report No 8, Linköping: Linköping University Electronic Press, 111-21.

Winter, J. (1995) Sites of Memory, Sites of Mourning: The Great War in European Cultural History, Cambridge: Cambridge University Press. 


\title{
MUSEUMS, NATIONS, EMPIRES, RELIGIONS
}

\author{
Tony Bennett
}

My concern in this chapter is to explore the implications of two perspectives for our understanding of the relations between museums, nations, empires and religions as these have developed from the late eighteenth century to the present. I derive these perspectives from Kevin Hetherington's suggestion that museums are 'seeing-saying machines' that act as points of emergence 'in which some social relations are established and others are broken down' (Hetherington 2011: 459). Hetherington puts forward this view in the course of discussing the implications of Foucault's account of power when interpreted through the lens of Deleuze's concept of the diagram. This, in rough summary, consists in the distinctive orderings of the relationships between the seen and the said that inform the operations of particular institutions: schools, factories and, of course, museums too. Hetherington draws on this concept of diagram to highlight two aspects of the part museums play in the processes through which particular forms of power are shaped and exercised. The first consists in the transformative capacities of the truths - the models for new realities - that they produce and circulate. The second concerns the operation of these truths in the context of multiple, intersecting power relations rather than as vehicles for the transmission of a single principle of power holding sway over the entire social order.

I shall, in what follows, draw on these two perspectives in conducting a set of strategic probes that will provide different points of historical and theoretical entry into questions concerning the action of museums in the context of their enduringly significant, but always mutable, entanglements across the relations between nations, empires, and religions. I take the theoretical bearings for my first probe from Benedict Anderson's influential assessment of the role museums have played in shaping the imagined communities of nations into being (Anderson 1991). I do so, however, with a view to qualifying and complicating Anderson's argument by reviewing the continuing significance of the transnational forms of imagined 
community - dynastic, political and colonial empires and world religions - for the practices of European (and some other) museums throughout the greater part of the nineteenth and twentieth centuries. My second probe considers the relations between museums and religions from a different perspective: that provided by Michel Foucault's account of the relations - simultaneously ones of historical affiliation and ones of rupture and discontinuity - between pastoral and governmental forms of power. My concern here will be to show how, for the greater part, the alignments between museums and religions forged in the course of Western modernity are ones that have subordinated pastoral to governmental power by invoking religion as a form of moral supplement to secular practices of social governance. My third probe will explore the place of museums in the context of contemporary practices of tolerance understood, as Wendy Brown proposes, as a new historical form of governmentality (Brown 2006). This will involve a consideration of the respects in which earlier alignments between museums and religion have been unsettled by the new terms of engagement with religions that museums increasingly face in multi-faith polities.

\section{National/transnational intersections}

Let me come, then, to my first probe. Although not initially so, ${ }^{1}$ museums came to occupy an important place in Anderson's conception of the nation as an imagined community, that is, as a territorially defined fusion of people and culture that derives its essential unity from the deep past in which it is imaginarily anchored and which is projected forward into a seemingly limitless future. While at first stressing the role of print-based media - particularly newspapers and novels - as his favoured cultural technologies of nationing, Anderson subsequently accorded equal significance to the role of museums, alongside maps and censuses, in organizing the spatiotemporal coordinates of people-nations. The aspect of his account I want to stress most, however, concerns the respects in which such spatiotemporal coordinates had to be won against those comprised by the transnational imagined communities of dynastic empires and religions, principally Christianity and particularly Catholicism, but, in some contexts, Islam too. But these have, of course, remained significant political and cultural forces that, from the eighteenth century through to the Second World War and, indeed, into the present, have continued to inform the trajectories of European national museums. These trajectories have also been profoundly affected by the roles that such museums have played in relation to the national imperialisms that developed from the mid-nineteenth century and by the national-political empires of the twentieth century. Through their associations with the Hapsburg, Ottoman, Napoleonic and Soviet Empires and the Third Reich and with the transnational formations of the British, Belgian, French, Danish, Dutch and German overseas empires, Europe's national museums have been endlessly reconfigured as they have been placed, first on one side and then on another, of the changing boundaries, within or beyond Europe, that the flux and flow of these empires have generated. The processes in which museums have thus been caught up are always 
specific to particular constellations of national, sub-national, becoming national, and supra-national imperial/colonial formations. Nonetheless, the Eunamus reports do help to distinguish some general patterns regarding the ways in which national museums have been constructed - and, in many cases, deconstructed and reconstructed - in the context of variably constituted national/transnational relations.

The role of royal collections in organizing transnational dynastic spatiotemporal coordinates, against which national museums would later pitch themselves as parts of nationalist independence movements, provides one and, initially, perhaps the most distinctive articulation of such relations. In such cases the museums at the centre of such dynastic formations are initially both imperial and proto-national. Denmark is a good example. At the time of the initial establishment of the Royal Chamber of Art - a collection of natural, art and cultural objects - Denmark was the centre of a transnational Scandinavian dynasty that included Norway, Greenland, Iceland and the German-speaking provinces of Sleswig, Holstein and Lauenburg. Questions concerning the role of museums in articulating a distinctive sense of Danishness that centred on a people-nation defined in terms of the territorial and historical coordinates of present-day Denmark came to the fore only with the loss of these dynastic possessions over the period from 1814, when Norway became independent, through the secession of the German-speaking provinces in 1864 to, much later, the independence of Iceland in 1944. The establishment of a distinction between the properties of the royal household and those of the Danish people-nation that followed the overthrow of absolutism and the establishment of a constitutional monarchy in the aftermath of the revolutions of 1848 constituted a key moment in the development of the political and legal conditions for a distinctively national cultural patrimony centred on an emerging suite of national museums: the National Museum, the National Gallery of Denmark, the Museum of Natural History and the Danish Folk Museum. The other side of this process consisted in the role of museums as rallying points for nationalist independence movements and, later, as key cultural markers of national independence in the territories that had won independence from Danish rule. These processes in their turn had knock-on consequences for the relations between Danish museums and Danish identity, as cherished collections that had played a key role in defining a sense of Danish nationhood centred on its colonial possessions had to be reworked once those collections were reclaimed as symbols of national independence. The late nineteenth-century development of the Danish Folk Museum was one response to these developments, involving a shift away from a sense of nationhood defined in terms of transnational possessions and toward a discovery of a Danish folk culture for a new and more vernacular nationalism. The return to Iceland of the Saga manuscripts at various points over the period between 1925 and 1979 occasioned similar twentieth-century adjustments.

There are many examples of these processes as, across the longue durée of 1750 to 2010, what now stand as independent national museums were initially shaped in the context of their struggles against transnational imperial formations of one kind or another: of Estonia and Finland, for example, against the Baltic empire of tsarist 
Russia; of Bulgaria against the western reaches of the Ottoman Empire; and of Lithuania in relation to Poland and, later, Russia. And, of course, there are also cases in which museums have proved to be key material and symbolic operators in the processes through which nations have emerged as the centres of new empires, focused largely within Europe, through wars of conquest. The concentration of expropriated property in newly nationalized museums at imperial centres has been of enormous significance in this regard. The seizure of the Louvre disconnected it from the dynastic power of the French royal household, while its subsequent development as a central repository for cultural property expropriated from conquered territories transformed it into a symbol of an imperium centred on the French people-nation. Its influence in this regard was far-reaching and multiedged. On the one hand, these expropriations were resented, stimulating alternative national museum projects across the length and breadth of Europe. On the other hand, such projects also often sought to emulate the new relations between cultural property, museums and national patrimony represented by the French conception of such patrimony as the bequest of a democratic people-nation. The establishment in Belgium of the proto-national Musées royaux des Beaux-Arts de Belgique in 1801 is an example of these processes: following the French example, it hastened the process of secularizing religious works of art, and provided the basis for a national collection of paintings that, alongside the development of new museums following in the wake of Belgium's establishment as an independent constitutional monarchy in 1830, constituted the nucleus of a national cultural patrimony. There was a third pattern too: that of ensuring that the relations between the principles of dynastic and national power remained intact at the expense of their association with a democratic conception of the people-nation the position that informed, and inhibited, the development of the National Gallery in Britain in the early nineteenth century.

The roles of museums in the post-1944 Soviet empire raise a different set of questions. In the Eunamus study, these questions mainly come into view through the strong connections that were forged between museums and national liberation movements that both helped to bring about, and were accelerated by, the break-up of the Soviet Union in 1989: in Bosnia-Herzegovina, Slovenia, Estonia and Lithuania, for example. The particularities of these cases are different with regard to the specific types of museum that were accorded pride of place within these independence struggles. There are, however, significant similarities between them in their shared rejection of communism and its class-based terms of reference for museum practice as an alien, externally imposed ideology, and the search for - or rediscovery of - an ethnos that could (re)root the nation in authentic national-popular traditions. There is, however, another aspect to Russia's influence on European museum practices, one located between the imperium of tsarist absolutism that was centred on the Hermitage and its post-war communist empire. I refer to the period from the 1920 s to the early 1930s when, in the context of calls from the Office Internationale des Musées (OMI) for museums to be developed as instruments of popular democratic instruction, the museum practices of post-revolutionary Russia were widely looked 
to, alongside those of the United States, as models for Western European countries to follow. ${ }^{2}$ They had a significant influence on the relations between museums and the politics of the Popular Front in 1930s France, in part due to George Henri Rivière, who, after a study tour, assessed them as peerless examples of the popular and democratic forms of public pedagogy that he and Paul Rivet aspired to at the Musée de l'Homme (Gorgus 2003).

A further set of museum/transnational relations I want to highlight consists in the development of museums as the key cultural and material operators of overseas empires reaching beyond Europe. These arose, in some cases, in connection with eighteenth- and early nineteenth-century histories of colonial conquest and occupation. This was most conspicuously true of Britain in its relations to India, Australia and New Zealand. In other cases, these developments came later: the role of museums in the relations between France and its territories in West Africa and Indo-China (de L'Estoile 2007); between Germany and Samoa, Qingdao and Southwest Africa (Penny 2002; Zimmerman 2001); and between Belgium and the Belgian Congo, with the establishment of the Musée du Congo Belge in 1910, are all cases in point. There are three aspects of these developments that merit particular emphasis. The first concerns the significance they accorded to prehistoric archaeology and anthropology, particularly physical anthropology, as relatively new disciplines that had a profound influence on museum practices throughout Europe. By introducing new kinds of material objects into museums, they significantly restructured the organization of the artefactual field. They also issued a significant challenge to the authority of more established disciplines - biblical hermeneutics and classical archaeology for example - and did so largely on the part of a new class fraction that based its claims to social authority on new forms of scientific expertise (Bennett 2004). Third, and perhaps most important of all, however, they enormously increased the importance that attached to questions of race and racial hierarchies within the operations of museums. This was not, of course, entirely new: anatomically grounded conceptions of racial hierarchies are evident in European museums from the late eighteenth century. From the second half of the nineteenth century, however, the role of museums in the organization of metropolitan national identities comes to be inextricably tied up with the differentiation of European/Caucasian races from other races, sometimes in accordance with polygenetic and sometimes in accordance with evolutionary conceptions of racial differences, and various complex combinations of these.

This set of museum/transnational relations did not revolve simply around the relations between museums centred in Europe and their colonial territories; indeed, these relations were more typically operationalized through the connections that were established between metropolitan museums in Europe's capital cities and museums that were developed in situ in colonial contexts. Again, the timescales here varied: such connections were established quite early in the case of the relations between Richard Owen at the British Museum and the Australian Museum that was established in Sydney in 1827 (albeit not named as such until 1834), for example (Rupke 1994; MacKenzie 2009), and much later in the case of the 
establishment of museums in France's overseas territories - the Musée de l'Homme that was established in Hanoi, in 1938, for example (Dias 2012). These connections resulted in complex socio-material networks through which the flows of people (curators, 'natives' as 'live exhibits' and, sometimes, as visitors) and things (collections) between metropolis and colony were organized. These networks did not, however, operate as one-way instruments for imposing an imperial identity on the colonized. ${ }^{3}$ They rather formed parts of complex systems of transnational exchange through which identities in the metropolis were shaped just as much as those in the colonies. Exhibitions of Indian material culture thus played a significant role in organizing late nineteenth- and early twentieth-century conceptions of Britishness, particularly through the role of the Victoria and Albert Museum. The fieldwork missions organized by the Musée de l'Homme in the 1930s, particularly the DakarDjibouti mission led by Marcel Griaule, played a similarly important role in helping to shape a new conception of French identity as a part of Greater France, reaching beyond the Hexagon to encompass French men and women and their colonial cousins as members of an imaginary transnational family (Bennett 2013; Lebovics 1992; Wilder 2005).

There was also a good deal more than identities at stake, particularly in the case of the flows of natural history and ethnological collections that such networks organized. In these cases European museums often provided the centres of calculation through which the governance of both the new natures of colonial agricultural ecologies were managed and through which biopolitical programmes of managing indigenous populations - frequently to extinction - were put into effect. Where this was the case, museums formed parts of transnational killing machines in which the ordering and classification of races that resulted from the analysis of the cultural materials and body parts of colonized populations that had been gathered together in places like the Pitt Rivers Museum in Oxford were complexly entangled in the processes that led to the enactment of policies of ethnocide along varied colonial frontiers (Bennett 2010). Their entanglement in the processes through which populations were distributed across the biopolitical divide separating 'what must live from what must die' (Foucault 2003: 254) had mortal consequences in Europe, too. The role played by ethnographic collections in Germany in assembling cultural materials and body parts from its Jewish and Romany populations alongside those brought back from Germany's overseas colonies contributed significantly to the development of the principles of racial science and hygiene that informed the practices of the Holocaust (Zimmerman 2001).

In these and other ways, then, European national museums have been shaped by, and helped to shape, the fluctuating dynamics of varied sets of transnational relationships. ${ }^{4}$ The social and cultural logics deriving from the intersections of these dynamics have significantly influenced the particular disciplines that have most informed the practices of museums in particular historical contexts. There is, across the Eunamus reports, a remarkable degree of consistency with regard to the disciplinary knowledges that have been 'in play' in different national contexts: classical archaeology, ethnography, anthropology, folk culture studies, art history, natural 
history, the history of science and technology, art and design, musicology and, of course, history. However, the strategic significance that attaches to these disciplines is often highly specific and variable, depending on the particular kinds of symbolic weight they carry in particular circumstances.

A number of national museums, for example, have shared a strong interest in classical archaeology, and especially in Greek archaeological collections. However, depending on the context, this has been for very different reasons. In Greece itself, early nineteenth-century disputes challenging assumptions about biological continuities between ancient and modern Greeks made archaeological engagements with Greek antiquities central to the demonstration of the cultural and historical continuities that were needed to support Greek claims to statehood. The early twentieth-century promotion of philhellenism on the part of Greek Cypriots and the stress this placed on classical archaeology formed part of a struggle against the parallel promotion of Islam on the part of Turkish Cypriots. The nineteenthcentury appeal to Hellenic culture in German museums, while having many aspects, not least its associations with the aesthetic practices of Bildung (Marchand 1996), also provided a nuanced national critique of the imperial associations of Napoleon's Roman collections.

The regularity of the appeal to the folkloric and ethnographic disciplines centred on the everyday cultures of the people where museums are connected to national independence movements - as in the Basque region today, for example - is also notable. So is their absence in other contexts - England, for example - where, in contrast to many other countries in Europe, the folk disciplines failed to gain any significant traction in national museums until the post-war period and, even then, their influence remained relatively modest. ${ }^{5}$ The specific historical circumstances relating to the role of amber as 'northern Lithuanian gold' (Rindzevičiūte 2012: 233) similarly account for the significance accorded to geology and archaeology in fashioning a mineral resource into a symbol of national identity at the Amber Museum that was opened in Palanga in 1963.

It is also, and finally, difficult not to be aware of just how much 'difficult heritage' (Macdonald 2009) there is in Europe. The intersections of racial, national, imperial, religious and ethnic fault-lines within and across national borders within Europe have meant that there are now few places where there are not difficult pasts that have to be negotiated. Some of these are on a larger scale and more consequential than others, with Holocaust museums of various kinds being the most important. But the phenomenon is much more widespread: museums addressing the histories of persecution of Romany peoples, for example. And, of course, there are parallel forms of difficult heritage that are currently under negotiation across the fault-lines produced by histories that have traversed the relations between European nations and their colonies. In France, England and Belgium the museum/ nation/people nexus is currently in the process of being refashioned in the context of the difficult colonial legacies that still inform the collections and the exhibition practices of many European museums. These refashionings, far from being processes internal to the nations concerned, have been invariably prompted by 
organized transnational communities of action - religious, multicultural, indigenous - in calling for the reordering, reclassification or repatriation of cultural materials that have been in transit across fluctuating national boundaries with, and within, Europe. The significance accorded museums by the Sámi - a transnational indigenous people living in Sápmi, a cross-national territory spread across parts of Norway, Sweden, Finland and Russia - is a particularly telling case in point. As a transnational community of action within Europe, it is also one that has drawn on the models and strategies developed by post-colonial struggles against Europe.

In summary, then, what most stands out from the panoramic overview that is, for the first time, made possible by the Eunamus reports, is how unstable the relations between museums and nations have proved to be. Museums, we might say, are always caught up in processes of either becoming national or (so to speak) of un-becoming and re-becoming national depending on how, at any particular moment, they are placed in relation to the flux and flow of boundaries resulting from military and colonial conquests, decolonization struggles, and independence and secessionist movements. Of course, this is truer in some contexts than others: more true of territories in Central and Eastern Europe affected by the mobility of boundaries associated with the collapse of dynastic empires and histories of military occupation than of Britain, for example. Even there, however, the division of Ireland in 1922 and the independence of Eire, and the subsequent strength of the movement for Scottish independence, have resulted in centrifugal forces entailing successive redefinitions of the forms of 'Britishness' that the British Museum is supposed to embody.

\section{Museums and the relations between pastoral and governmental power}

It is important, however, to come now to my second probe, to recall that the imagined community of the nation has had to be fashioned into being against not just the imagined communities of transnational dynastic and imperial formations. Such national imaginings, Anderson argues, have also had to be shaped sometimes against and sometimes in an articulated relationship with - the imagined communities of transnational religions. Questions concerning the relations between museums and religions are of enormous contemporary significance. They are, however, questions that have received relatively little focused attention and where they have been considered this has largely been from an anthropological perspective focused on the relations between the ritual aspects of museum visitation and practices of religious observance (see, for example, Bouquet and Porto 2005; Paine 2000). There is a particularly notable shortage of inquiries into the respects in which historical transformations in the relations between museums and religions have been parts of wider changes in the organization of particular regimes of power and authority.

While this neglect cannot be adequately compensated for here, some pointers to the directions such inquiries might take are suggested by Michel Foucault's 
comments on the relations between pastoral and governmental forms of power. Foucault approaches pastoral power as a form of power specific to the Christian pastorate and, as such, distinct from the forms of power exercised by Hebraic and Islamist religious authorities. Tracing its development over the period from the second to the eighteenth century, he also argues that pastoral power is a mode 'from which we have still not freed ourselves' (Foucault 2007: 148) and which, unlike the principles of feudal power, has not yet experienced a revolution 'that would have definitively expelled it from history' (Foucault 2007: 150). Foucault defines pastoral power as 'an art of conducting, directing, leading, guiding, taking in hand, and manipulating men ... collectively and individually throughout their life and at every moment of their existence' (Foucault 2007: 165). Its innovation consists in its use of a technique for self-examination and the examination of others through which 'a certain inner truth of the hidden soul, becomes the element through which the pastor's power is exercised, by which obedience is practiced ... and through which, precisely, the economy of merits and faults passes' (Foucault 2007: 183). It is this economy of faults and merits - not, as with the Hebraic pastorate, a relationship to salvation, truth, or law - that comprises the distinctive modus operandi of Christian pastoral power.

Foucault sees the period from 1580 to 1648 - the end of the Holy Roman Empire and the establishment, via the Treaty of Westphalia, of the modern state system - as characterized by two parallel processes leading toward the establishment of the distinctive forms and divisions of modern Western governmental power. These consisted in the diminishing power of the anthropocentric world of prodigies, marvels and signs interpreted as the manifest form of God's government of the world when faced with the emerging influence of the classical episteme. Although a more complicated story, this development is partly enacted in the history of curiosity as, in Krzysztof Pomian's terms, a period of 'interim rule between those of theology and science' (Pomian 1990: 64) in which the power of the clergy and of royal households to monopolize the public exhibition of semiophores - Pomian's term for objects that mediate the relations between the visible and the invisible worlds they construct - was challenged by new social stratum of humanist intellectuals. The culture of curiosity, however, itself later gave way, in France, to the scientific authority of museums of natural history depicting the autonomous laws of nature as part of a rationalist didactics directed toward the instruction of the public. This 'degovernmentalisation of the cosmos' (Foucault 2007: 236), which detached nature from any rationality but that of its own laws, was accompanied by the emergence of another form of rationality in which the power of the prince was no longer modelled on that of the pastor in relation to his flock. This was a rationality in which the principle of sovereignty - hitherto largely self-subsistent and self-sufficient - was supplemented by and subordinated to raison d'état: the governance of the res publica as the realm of the state. Whereas up until the start of seventeenth century sovereignty had meant governing in accordance with the laws of the country, those of nature, those of God, and historical models of good behaviour, raison d'état involved the organization of a new knowledge/government nexus: a knowledge of the forces and 
resources that constitute the state; and a knowledge of the attributes of the population and of the forces and conditions - medical, sanitary, environmental - shaping those attributes. It also involved a new practice of the truth concerning the public whose members must be acted on no longer to impose beliefs of legitimacy 'but in such a way that their opinion is modified, of course, and along with their opinion, their way of doing things, their way of acting, their behaviour as economic subjects and as political subjects' (Foucault 2007: 275).

It was in relation to these two aspects of raison d'état that the elements of governmental power were initially assembled. Foucault's contentions concerning the continuities between pastoral and governmental power are, however, quite general, often speculative, and have occasioned a good deal of disagreement. Mika Ojakangas (2012) convincingly argues that it is those aspects of governmentality that focus on the welfare of the poor that have their origins in the pastorate, while the biopolitical aspects of governmentality constitute a rejection of the Christian pastorate and a reversion to the classical models of population management of Greece and Rome. The literature exploring the relations between pastoral and governmental forms of power in colonial contexts enjoins a similar caution. The introduction of biopolitical forms of governmentality in such contexts usually depended on the displacement of missionary deployments of pastoral power by the new forms of authority that accrued to fieldwork anthropology in providing a knowledge of how to manage colonized peoples through the manipulation of their relations to their environments (Blake 1999).

The aspects of Foucault's argument that I want to focus on here, however, concern the respects in which pastoral power was translated into a range of techniques of self-governance associated with the various forms of counter-conduct that were raised against it (Petterson 2012). Some of these arose out of the criticisms that Reformation clerics directed against the forms of priestly authority associated with Catholic versions of pastoral power, while others were generated by ascetic or mystical movements. The significance of these counter-conducts was that of displacing the power of the pastorate and the absolute forms of obedience this required and substituting technologies of governance that depended on varied forms of self-mastery and self-regulation, albeit that, as Foucault rightly notes, these were always exercised under the direction of some other authority that was pitted against that of the pastorate. There are numerous connections between the forms of self-regulation associated with these counter-conducts and later forms of governmental power. The forms of self-inspection associated with the technology of the confessional, and thereby subordinated to pastoral direction, were, in the early history of English aesthetic thought, translated into techniques for surgically splitting the self that provided a mechanism for inner self-direction, which played a key role in the development of early forms of liberal government directed against the authority of the pastorate (Bennett 2013: Chapter 6). The same was true of the role that Pietism played in Germany in developing those practices of self-inspection that later informed the culture of Bildung as a cluster of techniques of free and independent self-regulation and self-cultivation which played a crucial role in the 
development of late nineteenth-century bourgeois culture (Koselleck 2002). The routes through which pastoral forms of power were translated into a range of techniques of self-monitoring that were conducted under the guidance of the schoolmaster in nineteenth-century popular schooling have also been examined (Hunter 1994).

The development, since the late eighteenth century, of the public museum form has been caught up within - both being shaped by and helping to shape - these complex historical negotiations of the relations between pastoral and governmental forms of power. It is, however, difficult to offer any general account of these matters. This is partly because the relations between museums and organized religions have varied in different national and imperial contexts. The late nineteenthcentury development of national museums in both France and Italy formed a part of the organization of a secular polity that was pitted against the power of the papacy, with museums playing a significant role in chiselling out a space in which the attributes of national citizenries might be shaped by detaching them from the influence of transnational religious communities. This was much less true in Spain and Portugal, where there was a less clear separation between the Catholic Church and museums, and where the significant presence of Islam was a further complicating factor. Nor can the relations between museums and religions be told as part of a general process of secularization. The transfer of meanings and practices across the relations between museums and churches, and between practices of religious observance and those of museum attendance, is well-trodden ground: the translation of religious ceremonial forms into museum-going as a civic ritual (Bennett 2006; Duncan 1995); the influence of religious architecture on museum design; ${ }^{6}$ and the transitions - not altogether seamless - between museums and cathedrals on tourist itineraries (Arthur 2000) are three cases in point. When, then, Sharon Macdonald interprets museums as 'culturally demarcated spaces of concentrated meaning involving a degree of culturally regularised collective performance' (Macdonald 2005: 210), she is right to draw our attention to the elements of magic and enchantment that such rituals involve, and to query Enlightenment conceptions of a stadial progression from magic through religion to science that informed the development of the nineteenth-century public museum - 'the "established church", as she puts it, "of the museum world' (Macdonald 2005: 213).

Nonetheless, when all of these qualifications are entered, the emergence of the social as the object and target of government that is associated with the development of modern forms of governmentality constitutes a decisive historical transformation of the relations between states and religions. Accounts of the emergence of governmental forms of power are most usually contrasted with the principles of sovereignty that lacked that crucial interest in 'the state of society, its economy, or a precise enumeration of its inhabitants' (Desrosières 1998: 27) that later informed the development of statistics as a 'state science' orientated to providing a knowledge of society. Keith Baker helpfully stresses the respects in which this conception of the social as the determining ground of existence, constituting the forces and relations that governmental activity must act on in order to improve the health and 
wellbeing of the population, displaced the force of religious imaginaries in a different way from that implied by Anderson's account of the shift from a transnational to national forms of imagined community. The shift is rather from an order of existence imagined as emanating in its entirety - human and natural, metaphysical and physical - from a divine source to one in which a population, usually defined in terms of national boundaries, is regarded as being conditioned by the milieus that shape the relations between its inhabitants.

There are significant connections here - recalling Anderson's comments on the relations between museums, maps and censuses - with the role played by museums in organizing the national geospatial coordinates of modern forms of governmentality (Hannah 2000: 1-2). The process of shifting from a religious to a governmental conception of the forces ordering the conditions of existence for populations supplied the coordinates for a new form of state-society schematization. This is a schematization in which the social is 'assumed to possess its own regularities, autonomous life, and independent existence' (Baker 1994: 197), and it is the forces shaping these that the state must come to know if it is to act on, regulate, improve - in short, govern - the population. The consequent development of new forms of expertise providing a knowledge of social laws to guide the conduct of the state, Baker argues, repositions the place that is accorded religion as, in varying ways and to different degrees, it is invoked as a moral force that can supplement the activities of state authorities in working to secure specific ends. The service that religion is thus called on to perform is one that enlists it as an adjunct to the governmental state and brings it to bear on a society that, separated from a divine cosmology, is presumed to exist independently on its own foundations.

These developments had profound consequences for the development of museums alongside those I have already traced in which the principle of sovereignty associated with royal collections is transferred to the 'people nation' of democratic polities. These consisted in the development of museums as reformatory apparatuses in which pastoral techniques of self-inspection and self-shaping where redeployed under the direction of a new set of disciplines associated with the development of the modern 'exhibitionary complex' (Bennett 1988). This transformed the pastoral economy of faults and merits into a civic economy of faults and merits in which it was customs, manners, beliefs and everyday forms of conduct of health and hygiene, for example - that were to be transformed with a view to achieving certain social ends. The modus operandi of museums within the space of this state-society schematization varied according to the type of museum. But we can see something of the logic that was at work in how nineteenth-century English cultural reformers viewed the relations between art galleries, places of religious worship and the tasks of social reform. Whereas the poor had previously had access to the fine arts - 'the handmaidens of religion and gentle culture' - through churches, abbeys and cathedrals, Henry Cole warned that it was no use looking to religion as a cure for drunkenness as the 'millions of this country have ceased to be attracted by our Protestant churches and chapels, and the law cannot compel them to attend' (Cole 1884: 368). In urging the need for public investment in art 
galleries as a means of filling this gap Cole assessed religion as ineffectual from the point of view of the role he assigned it as a supplementary moral force to be applied in securing social objectives.

Another way of coming at these issues is suggested by Patrick Joyce's observation regarding the central role that the church had played in the relay of sovereign forms of power. He has in mind the public readings of royal proclamations that took place in English parish churches - churches that were, after the establishment of the Church of England, arms of the state (Joyce 2013: 59). If this role fell by the wayside in the course of the eighteenth century, this was, Joyce argues, because of the close set of connections that informed the subsequent development of the liberal state as a set of mechanisms for organizing freedom - that is, for developing 'governmental techniques that allowed, and still allow, designated governed entities (persons, places, things) to operate ostensibly on their own, without outside interference' (Joyce 2013: 3) - and its role, as a 'communications state', in fostering the development of transport and communications infrastructures through which people, knowledge and things could flow freely. For if we are to understand their operations correctly, the development of museums, as mechanisms for the development of self-civilizing subjects, has to be considered in terms of their relations to such infrastructures: the development of public libraries, of national and transnational transport systems (railways and shipping lines), of gas and - later - electric lighting and, as Joyce's particular concern here, postal systems. For it was through these connections that museums came to be related to other mechanisms for the cultivation of liberal forms of subjectivity - the relations between public lighting and the visual self-regulation of society in the new sites in which its members assembled, for example (Otter 2008) - in ways that stitched them into the regular mechanisms of the governmental state at the same time that religions were sidelined' into ancillary roles.

At the same time, however, these communications systems went beyond national boundaries, locking in place mechanisms for the transnational dissemination of these techniques for the production and management of liberal subjectivities. Alison Inglis (2011) has detailed the operation of these mechanisms in the relations that bound the fledgling art field of late nineteenth-century Australia into significant relations with a wider imperial art field centred on Victorian London. The colonial art museum; an imperial system of art teaching; and international exhibitions - these, Inglis argues, allied with changing transport technologies (the change from sail to steamships), made possible a complex set of two-way transfers between Britain and the Australian colonies that folded both into a broader transnational field. The to and fro movement of artists, casts, catalogues and copies; the circulation throughout the British empire of art teachers trained at the South Kensington Museum; the use of the circulation department at South Kensington to organize touring art exhibitions around imperial and not just national circuits; the backward and forward transit of examination papers and of art students; the networks between British and colonial societies for promoting a knowledge of art: in all of these ways, as well as in interlocking art markets (Caruana and Clark, 2011), communications networks 
inserted the national cultural fields within which museums operated within broader circuits of exchange and action.

\section{Testing tolerances}

I come, finally, to my third probe concerning the role of museums in the promotion of religious tolerance as a new historical form of governmentality. Hegel, it will be recalled, conceived the art gallery as a place which uprooted works of art from their originating contexts - including those of Christian worship. By bringing such works together in ways that allowed new meanings to be produced and made visible by exhibiting them within the same space, the art gallery made possible a secular politics of culture. ${ }^{7}$ This conception was condensed, Helen Rees Leahy (2012: 4) reminds us, in Hegel's observation that the museum visitor need no longer kneel in front of a Madonna. In asking when and how visitors learned not to do so, she raises important questions concerning the varied means that museums have developed to shape the bodily comportments of their visitors and the limits to which they have been successful in this regard. Hegel's separation of art from religion was - as Dominique Poulot (1994) has shown - a cleaner break in theory than it was in practice, especially for untutored visitors who, unaware of the new forms of veneration that were required of them by the art gallery, continued to bend their knees before religious paintings. This is also true, albeit in ways that raise different questions, of contemporary conceptions of the art gallery space as one of cross-cultural encounters. In her discussion of the 2001 Buddha: Radiant Awakening exhibition at the Art Gallery of New South Wales, Ien Ang recounts the case of a Chinese woman who visited the exhibition every week to lay ceremonial crystals at the feet of a Buddha statue in memory of her recently deceased mother. If this converted an art exhibition into a sacred site, an art critic provided an alternative response in insisting that the purpose of the exhibition was, or ought to be, to promote 'the glories of Buddhist art, not Buddhism' if it were not to become 'a sacred service' (Ang 2006: 149). ${ }^{8}$ Ang's own position is that the art museum must be able to accommodate both responses if it is to serve the needs of a culturally diverse society.

This is a telling contrast that highlights the wider set of religious affiliations that have to be taken into account in considering the relationships between the state, culture and the social associated with contemporary forms of governmentality and the role accorded museums within these. In the British case, for example, the adjudication of civic entitlements between the members of different faiths centred mainly on relations within the confines of Christianity or, more generally, the JudaicChristian tradition for the greater part of the modern period, with the members of other faiths largely occupying the place of excluded outsiders (Saunders 2006). The increased international mobility of labour, the development of new citizenship agendas associated with the politics of recognition, and the growth of religious affiliation have transformed this situation significantly. Lamin Senneh (2006) usefully places this last tendency in a global perspective: in 1970, with a total world 
population of 3.7 billion, the Muslim population was 549 million and the Christian population 1.2 billion. By 2006 these two religions had expanded significantly, both absolutely - Muslims to 1.3 billion and Christians to 2.15 billion - and as percentages of world population (from nearly 15 per cent to close to 22 per cent for the Muslim population, and from a little over 32 per cent to nearly 36 per cent for Christians). Most of the growth of Christianity was attributable to its Charismatic versions: in 1970, the worldwide population of Pentecostal Christians was around 72 million, by 2005 it was nearly 590 million. The significance of religious affiliation is also closely connected to ethnic identifications. In the British case, religious affiliation is much more likely to translate into active religious participation for members of minority ethnic communities than it is for white Britons: in the last census, black Christians were about three times more likely to be regular churchgoers than were their white counterparts, while British Muslims were six times more likely to attend a place of worship weekly than were British Christians (Bradley 2006: 33).

The challenge that is posed for state cultural institutions in a period when faithbased divisions have become more sharply drawn is a microcosm of the challenges facing liberal-democratic polities more generally. In asking whether 'the traditional separation of church from state so carefully crafted in the West' can 'survive the renewed onslaught from religious fundamentalisms', Grahame Thompson suggests the need for a new settlement of the relations between state and religion:

The question becomes: 'can there be a dialogue of the gods?' Under such circumstances, peace must be composed anew. Peace is an undertaking; it must be fabricated and constructed between the parties. And the gods must be taken into the peacemaking chamber.

(Thompson 2006: 20)

What does it mean to take the gods into the art gallery or the museum more generally? And what does it mean when those gods force their way into such institutions? Ang's contention that art museums now need to function as hybrid environments in which aesthetic and religious relationships to the same objects might coexist in the same space is one response to this question. Others heighten the tensions between the claims of art, in the Western art system, to freedom of expression and autonomy in relation to both political and religious interference and the counter-claim that the state has a responsibility not to exhibit art that offends the religious sensibilities of the varied populations that are now its citizens - the controversies surrounding the exhibition of Andres Serrano's Piss Christ, for example. The claims that creationism should be exhibited alongside evolutionary theories in museums just as much as in schools - and the recent opening of Creation Museums in several US states - point in a similar direction, reigniting the controversies of the 1880s when evolutionary displays were first installed in institutions such as the British Museum of Natural History and the American Museum of Natural History in New York (Conn 2006). The dialogues between museums and 'the gods' have also occasioned significant re-evaluations of those ethnocentric 
conceptions of religion - often based on the text-based practices of Christianity that have shaped the relations between Western and other cultures. And questions concerning appropriate ways of exhibiting objects expropriated in colonial histories are now legion, ranging across the exhibition of ancient Egyptian funerary remains to the appropriate narrative and scopic regimes for the exhibition (if at all) of indigenous materials in new national museums (Erikson 2008).

Issues of these kinds relating specifically to museums inescapably connect with broader tendencies concerning the relations between religions in the public sphere. When, in Britain, Jack Straw - the Home Secretary at the time - and Prime Minister Tony Blair said that they viewed the burka as a sign of separatism and isolation, they added to the difficulties faced by Muslim women in public contexts in ways that have perhaps had no parallels in Britain since, in the aftermath of the 1829 legislation emancipating Roman Catholics from a whole series of restrictions, the reappearance in public of nuns in full habit resulted in their being criticized - and sometimes stoned or attacked - for publicly exhibiting their religious difference (Toynbee 2006: 33). And there are other ways in which questions of difference and the public sphere are now increasingly entangled with religion. The archbishop of Canterbury entered the foray in late 2006, taking local councils to task for substituting 'winter festival holidays' for 'Christmas', arguing that it was appropriate that the public sphere should remain Christianized in such matters. And in Glastonbury, in the autumn of 2006, an organization representing young Catholics marched through the town to reclaim it as a Christian shrine by demanding that pagan signs and rituals be excluded from the town. In their turn, pagan prisoners have urged the Home Office to recognize the pagan new year as a day of special spiritual significance for them while pagan organizations, including the Council of British Druid Orders, are now active in campaigns urging that British museums should return the remains they have collected from preChristian burial sites for pagan reburial (Randerson 2007: 3). They have, in doing so, drawn on the example of indigenous peoples in both their repatriation claims but also in obliging Western museums - in Europe as well as in settler-colonial contexts - to respect indigenous conceptions of sacredness in the ways in which they store, conserve, and exhibit sacred items or withhold these from public view.

There are, of course, significant differences between the social and political logics that these examples represent. They are all, however, examples of contemporary tendencies in which the central issue that is in question concerns how far issues of cultural difference can be managed within the subordination of religion to the statesociety schematism that has characterized Western forms of governmentality. This schematization was, and remains, intact in those multicultural framings of questions of cultural difference in which, as Ghassan Hage puts it, 'the state recognises the individual and their sub-national cultural identity, and it asks them to commit themselves and become attached to their multicultural nation' (Hage 2008: 498). Where such conceptions prevail, religious and secular authorities and institutions often work hand-in-glove with one another as representatives of different faiths are invited into the museum to assist it in what has now become its primary governmental assignment: that of contributing to the management of cultural differences 
through the promotion of cross-cultural and multi-faith understanding and tolerance. This is the case, for example, with Glasgow's St. Mungo Museum of Religious Life in its conception of itself as 'an intervention in society, a contribution toward creating greater tolerance and mutual respect among those of different faiths, and those of none' (in Arthur 2000: 12). A similar conception informs David Goa's placing of 'religiously based cultural communities' alongside other cultural communities as ones whose beliefs and values museums should bring into dialogue in discharging their "civic vocation in "the age of pluralism"” (Goa 2000: 52). In such conceptions religious forms of authority are invoked as a supplementary moral force operating within state organized fields of action within which the relations between religious, cultural and religious-cum-cultural differences are to be managed.

The situation is different with regard to those Muslim migrants who, as Hage put it, 'take their religion seriously'. For what this means, he argues, is to live in a parallel space - simultaneously transnational and transcendental - that is "ruled by divine law and that is constantly intertwined with and yet separate from the spaces of everyday life ruled by national law' (Hage 2008: 505). This entails a reversal of the state-society schematism that has framed Western forms of multiculturalism in that it is 'the laws of God that are the all-encompassing ones and the national laws of the host nation that are the minor ones. ... the laws of nation merely regulate the order of things within the nation while the laws of God regulate the order of things tout court' (Hage 2008: 505). Steven Engler has reflected usefully on these questions in discussing Pierre Bourdieu's account of the relations between the state and religion in the consecration of different forms of capital. Engler reminds us that Weber's account of the relations between different forms of religious capital that are in play in the struggles between priests (or churches) and prophets (their heterodox challengers) over the 'routinisation of charisma' within the religious field provided the model for Bourdieu's account of the role of the state in valorizing and regulating the reproduction of the different forms of capital which are in play across the range of differentiated fields (economic, social, political, cultural) that characterize advanced modern societies. In doing so, he suggests that Bourdieu overestimated the degree to which the centrality of the state had displaced religious forms of capital accumulation and consecration. Far from being anachronistic, he argues, the growth of Pentecostalism and the renewed force of fundamentalisms suggest that religion remains a more important source of consecration than Bourdieu's formulations allowed, thus calling into question 'his hierarchical subsumption of all fields under the field of power as unified by the state' (Engler 2003: 454). This is also to call into question the subordination of religious truths - and the authorities for those truths - to the state-society schema within which Christian forms of pastoral power came to be deployed.

\section{Conclusion}

I indicated at the outset of this chapter that I would approach museums from the perspective of the transformative capacities engendered by the regimes of truth 
they participate in; and that I would consider how these regimes of truth have operated in the context of different kinds of power relations. I have thus considered the roles that different museum disciplines have played in the processes through which museums have translated the principles of sovereignty from transnational dynastic and political formations to the constantly shifting peoplenations of what have proved to be remarkably mobile international boundaries. I have looked also at the ways in which museums have contributed - usually indirectly, but nonetheless consequentially - to the operation of racially organized forms of biopolitical power which, both within Europe, and in the relations between European nations and their colonies, have been directed toward the elimination of specific populations: Romany peoples, Jews and Australian Aborigines, for example. I have further considered how museums have been caught up in the entanglements between pastoral and governmental forms of power; how these entanglements have informed more recent agendas of multiculturalism, but also how the subordination of religion to governmental conceptions of the social that these largely Euro-American histories have produced are currently challenged by the resurgence of transnational forms of religious belief and authority that have either broken out of, or were not originally a party to, such conceptions.

This last set of developments unsettles the social logics that have informed the development of museum practices over the past 40 or so years. While museum practice has often been more innovative and more varied, the settings governing the general directions of museums in most European polities have been shaped by the confluence of multicultural and cultural diversity agendas. Whereas the former lay out the social in the form of a set of ethnically marked cultural differences whose interrelations have to be managed from a controlling centre that occupies the place of the nation, the latter treat the members of minority ethnic groups as equivalent to the members of other groups that - defined in terms of their gender, sexuality or disability, for example - are viewed as disadvantaged relative to general population norms. The intersections between these policy settings are, in their turn, often set within broader overarching objectives orientated toward achieving greater social cohesion or social inclusion. Most of these conceptual frameworks were developed in the 1980s and 1990s and took little account of what has, particularly since $9 / 11$ and its various aftermaths, become the more troubling challenge presented by transnational religions whose adherents sometimes refuse the place assigned them within such governmental logics. There is, for example, no specific engagement with questions of religion in the agenda-setting report Our Creative Diversity, begun in 1993 and published in 1995, that was prepared for UNESCO by the World Commission on Culture and Development. There has, since $9 / 11$, been no shortage of museum exhibitions focused specifically on questions of religious conflict or, more specifically, on an engagement with Islam. These are, no doubt, virtuous enterprises. How far they will be able to engage with those whose beliefs refuse and contest the social logics on which such activities are predicated is, however, far from clear. 


\section{Notes}

1 The first edition of Anderson's book did not include the chapter on museums, maps and censuses. Initially published independently, this was subsequently added to later editions.

2 The OMI, established in 1926 under the auspices of the League of Nations International Commission for Intellectual Cooperation, was a precursor to the International Council on Museums established in 1946. See Gorgus (2003) for further details.

3 For reasons that Chris Gosden (2004) has discussed, such networks always operate both ways.

4 Eglé Rindzevičiūte (2012) usefully identifies other transnational forces in her discussion of the influence of the post-war transnational regional Baltic space on the development of museums in Estonia, Latvia and Lithuania. She also pertinently stresses the respects in which European museums have, from their Enlightenment histories onwards, been shaped by their positions within international scientific networks. The role of international actors such as ICOM and the Council of Europe should also be mentioned. The Eunamus reports show clearly the important role played by such actors in prompting museums in Bosnia and Herzegovina, Slovenia and Italy to engage with questions of cultural and ethnic diversity.

5 I draw here on Chris Wingfield (2011), who argues that the global ambitions of museums in Britain at the height of empire precluded the focus on material closer to home that came only with the post-war loss of empire.

6 The crossover between them is evident in the architectural designs of many nineteenthcentury collecting institutions: the frequent use of Gothic and, particularly via Ruskin, its associations with a secularized form of medieval Christianity, for example, as well as Richard Owen's conception of the British Museum of Natural History as a 'cathedral of science' in which the Platonic archetypes of divine creation might be exhibited (Owen 1862).

7 I draw particularly on Didier Maleuvre's (1999) discussion of Hegel here.

8 Chris Arthur (2000: 13) provides a nice counterpoint to this in noting a sign at Cologne Cathedral that warned: 'THIS IS NOT A MUSEUM.'

\section{References}

Anderson, B. (1991) Imagined Communities: Reflections on the Origins and Spread of Nationalism, London: Verso.

Ang, I. (2006) 'The art museum as monument: cultural change contained', in M. Lake (ed.) Memory, Monuments and Museums: The Past in the Present, Melbourne: Melbourne University Press and the Australian Academy of the Humanities, 138-52.

Arthur, C. (2000) 'Exhibiting the sacred', in C. Paine (ed.) Godly Things: Museum, Objects and Religion, London and New York: Leicester University Press, 1-27.

Baker, K. M. (1994) 'A Foucauldian French revolution?', in J. Goldstein (ed.) Foucault and the Writing of History, Oxford: Blackwell, 187-205.

Bennett, T. (1988) 'The exhibitionary complex', New Formations, 4: 73-102.

- (2004) Pasts Beyond Memories: Evolution, Museums, Colonialism, London: Routledge. (2006) 'Civic seeing: Museums and the organisation of vision', in S. MacDonald (ed.) Companion to Museum Studies, Oxford: Blackwell, 263-81.

(2010) 'Making and mobilising worlds: assembling and governing the other', in T. Bennett and P. Joyce (eds.) Material Powers: Essays Beyond the Cultural Turn, London: Routledge, 190-208.

-(2013) Making Culture, Changing Society, London and New York: Routledge.

Blake, L. (1999) 'Pastoral power, governmentality and cultures of order in nineteenthcentury British Columbia', Transactions of the Institute of British Geographers, 24(1): 79-93.

Bouquet, M. and Porto, N. (eds.) (2005) Science, Magic and Religion: The Ritual Processes of Museum Magic, New York and Oxford: Berghahn Books.

Bradley, I. (2006) 'Face to faith', The Guardian, 13 January, 33.

Brown, W. (2006) Regulating Aversion: Tolerance in the Age of Identity and Empire, Princeton, NJ: Princeton University Press. 
Caruana, W. and Clark, J. (2011) 'Buying and selling Australian art: a brief historical survey', in J. Anderson (ed.) The Cambridge Companion to Australian Art, Melbourne: Cambridge University Press, 290-306.

Cole, H. (1884) Fifty Years of Public Work of Sir Henry Cole, K.C.B., Accounted for in His Deeds, Speeches and Writings, 2 vols, London: George Bell and Sons.

Conn, S. (2006) 'Science museums and the culture wars', in S. Macdonald (ed.) A Companion to Museum Studies, Oxford: Blackwell, 494-508.

de L'Estoile, B. (2007) Le goût des autres: De l'exposition coloniale aux arts premiers, Paris: Flammarion.

Desrosières, A. (1998) The Politics of Large Numbers: A History of Statistical Reasoning, Cambridge, MA: Harvard University Press.

Dias, N. (2012) 'Museums and ethnographic surveys in colonial Indochina', paper presented at the Colonial Governmentalities Workshop, Institute for Culture and Society, University of Western Sydney.

Duncan, C. (1995) Civilising Rituals: Inside Public Art Museums, London and New York: Routledge.

Engler, S. (2003) 'Modern times: religion, consecration, and the state in Bourdieu', Cultural Studies, 17(3/4): 445-67.

Erikson, P.P. (2008) 'Decolonising the "Nation's Attic": the National Museum of the American Indian and the politics of knowledge-making in a national space', in A. Lonetree and A.J. Cobb (eds.) The National Museum of the American Indian: Critical Conversations, Lincoln and London: University of Nebraska Press, 43-83.

Foucault, M. (2003) Society Must Be Defended, New York: Picador.

-(2007) Security, Territory, Population: Lectures at the College de France, 1977-1978, Houndmills: Palgrave Macmillan.

Goa, D. (2000) 'At play in the fields of meaning: Reflections on field research', in C. Paine (ed.) Godly Things: Museum, Objects and Religion, London and New York: Leicester University Press, 28-56.

Gosden, C. (2004) Archaeology and Colonialism: Cultural Contact from 5000 BC to the Present, Cambridge: Cambridge University Press.

Gorgus, N. (2003) Le magician des vitrines: Le muséologue Georges Henri Rivière, Paris: Éditions de la Maison des sciences de l'homme.

Guiral, J.M.L. (2011) 'National museums in Spain: A history of crown, church and people', in P. Aronsson and G. Elgenius (eds.) Building National Museums in Europe 1750-2010, Eunamus Report No 1, Linköping: Linköping University Electronic Press, 847-80.

Hage, G. (2008) 'Analysing multiculturalism today', in T. Bennett and J. Frow (eds.) The SAGE Handbook of Cultural Analysis, London: SAGE.

Hannah, M.G. (2000) Governmentality and the Mastery of Territory in Nineteenth-Century America, Cambridge: Cambridge University Press.

Hetherington, K. (2011) 'Foucault, the museum and the diagram', The Sociological Review, 59 (3): $457-75$.

Hunter, I. (1994) Rethinking the School: Subjectivity, Bureaucracy, Criticism, Sydney: Allen and Unwin.

Inglis, A. (2011) 'Imperial perspectives on art in nineteenth-century Australia', in J. Anderson (ed.) The Cambridge Companion to Australian Art, Melbourne: Cambridge University Press, 55-70.

Joyce, P. (2013) The State of Freedom: A Social History of the British State since 1800, Cambridge: Cambridge University Press.

Koselleck, R. (2002) The Practice of Conceptual History: Timing History, Spacing Concepts, Stanford, CA: Stanford University Press.

Kuutma, K. (2011) 'National museums in Estonia', in P. Aronsson and G. Elgenius (eds.) Building National Museums in Europe 1750-2010, Eunamus Report No 1, Linköping: Linköping University Electronic Press, 231-60.

Lebovics, H. (1992) True France. The Wars Over Cultural Identity, 1900-1945, Ithaca and London: Cornell University Press. 
Lozic, V. (2011) 'National museums in Bosnia-Herzegovina and Slovenia: A story in making "us ", in P. Aronsson and G. Elgenius (eds.) Building National Museums in Europe 17502010, Eunamus Report No 1, Linköping: Linköping University Electronic Press, 69-98.

Macdonald, S. (2003) 'Museums, national, postnational and transcultural identities', Museum and Society 1(1): 1-16.

-(2005) 'Enchantment and its dilemmas: the museum as a ritual site', in M. Bouquet and N. Porto (eds.) Science, Magic and Religion, 209-27.

(2009) Difficult Heritage: Negotiating the Nazi Past in Nuremberg and Beyond, London and New York: Routledge.

MacKenzie, J. (2009) Museums and Empire: Natural History, Human Cultures and Colonial Identities, Manchester: Manchester University Press.

Maleuvre, D. (1999) Museum Memories: History, Technology, Art, Stanford, CA: Stanford University Press.

Marchand, S. L. (1996) Down from Olympus: Archaeology and Philhellenism in Germany, 1759-1970, Princeton, NJ: Princeton University Press.

Ojakangas, M. (2012) 'Michel Foucault and the enigmatic origins of biopolitics and governmentality', The History of the Human Sciences 25(1): 1-14.

Otter, C. (2008) The Victorian Eye: A Political History of Light and Vision in Britain, 18001910, Chicago and London: University of Chicago Press.

Owen, R. (1862) On the Extent and Aims of a National Museum of Natural History, London: Saunders, Otley \& Co.

Paine, C. (ed.) (2000) Godly Things: Museums, Objects and Religion, London and New York: Leicester University Press.

Penny, G.H. (2002) Ethnology and Ethnographic Museums in Imperial Germany, Chapel Hill and London: University of North Carolina Press.

Petterson, C. (2012) 'Colonial subjectification: Foucault, Christianity and governmentality', Cultural Studies Review, 18(2): 89-108.

Pomian, K. (1990) Collectors and Curiosities: Paris and Venice, 1500-1800, Cambridge: Polity Press.

Poulot, D. (1994) 'Le musée et ses visiteurs', in C. George (ed.) La jeunesse des musées: Les musées de France au XIXe siècle, Paris: Musée d'Orsay, 332-50.

Randerson, J. (2007) 'Give us back our bones, pagans tell museums', The Guardian, 5 February, 3.

Rees Leahy, H. (2012) Museum Bodies: The Politics and Practices of Visiting and Viewing, London: Ashgate.

Rindzevičiūte, E. (2012) 'The geopolitics of distinction: negotiating regional spaces in the Baltic museums', in P. Aronsson and L. Graden (eds.) Performing Nordic Heritage: Everyday Practices and Institutional Culture, London: Ashgate.

Rupke, N.A. (1994) Richard Owen: Victorian Naturalist, New Haven and London: Yale University Press.

Saunders, D. (2006) 'What does liberalism inherit from early modern religious settlements?', Working Paper 16, ESRC Centre for Research on Socio-Cultural Change (www.cresc. ac.uk/publications/papers).

Senneh, L. (2006) 'Religion's return', Times Literary Supplement, 13 October, 13-14.

Thompson, G. (2006) 'Religious fundamentalisms, territories and "globalisation", Working Paper 14, ESRC Centre for Research on Socio-Cultural Change (www.cresc.ac.uk/ publications/papers).

Toynbee, P. (2006) 'Only a fully secular state can protect women's rights', The Guardian, 17 October, 33.

Wilder, G. (2005) The French Imperial Nation-State: Negritude and Colonial Humanism between the Two World Wars, Chicago and London: University of Chicago Press.

Wingfield, C. (2011) 'From Greater Britain to Little England: the Pitt Rivers Museum, the Museum of English Rural Life, and their six degrees of separation', Museum History Journal 4(2): 245-66.

Zimmerman, A. (2001) Anthropology and Antihumanism in Imperial Germany, Chicago: University of Chicago Press. 
PART II

\section{Museum typologies}

Art and cultural history museums 



\title{
4
}

\section{THE CHANGING ROLES OF ART MUSEUMS}

\author{
Dominique Poulot
}

In this chapter we put the history of the art museums in Europe, from the eighteenth century to the present day, in the broader context of the nation-building process, the political representations of heritage, and the consumption and pleasures of art. Our point of view is one of a cultural history of the nationalization and consummation of high culture, of its icons and values. The category of museum of art is a historical one, which is closely linked to the split, during the nineteenth century, of the category of the encyclopedic museum of the Enlightenment into separate realms and disciplines. Since the eighteenth century, the art system has established itself as a complex system with normative rules and structures (such as academies, art literature, criticism) to guarantee a 'disinterested' perception of the works (Kristeller 1951). The art world would not be imaginable in its modern form without the museum, that is to say an institution devoted to the history of its objects and to their catalogue (Waterfield 2000). But national museums of art were also founded to achieve political and social objectives - to influence the taste of the subjects or citizens, to mould their conduct and to provide assertions of the superiority and identity of national art. Art museums were ideal sites for the institutional politics of nationalism (Pointon 1994; Poulot 1997; Gaehtgens 1992; Wright 1996), and museum-going was a kind of civic ritual.

The relative importance of each national museum of art during the eighteenth and the first half of the nineteenth centuries was linked to the success or failure of each national academic system to emulate a common ideal of beauty, mostly based on the most beautiful antique statues of the museums of Rome. An international and more or less immutable canon determined the quality of each national production and its consequent celebration in the national museums. This state of things changed during the second part of the nineteenth century and canons became more diverse and related to Romantic ideals of popular culture and history. 
In any case, the full quality of each nation, manifesting itself in time with increasing plenitude, is connected with the existence and the qualities of its national spirit and national school, of artists, especially as the national museum collects and displays them, confronting their peculiar talents to other ones, putting in evidence their aesthetic strength and independence. The importance of the curator or director cannot be underestimated, even after the heroic period of foundation of the big museums when Dominique-Vivant Denon was able to mould the heritage of the biggest part of Europe as that of a single nation. The first model for a curator's career throughout the nineteenth and the first part of the twentieth century was that of the artist. Sometimes, this situation exemplified the continuity of a family such as the family of painters and curators of the Prado, who began to be in charge in 1838 when painter José de Madrazo (1781-1859) was appointed its director, and after him two of his sons played a crucial role in the development of the museum. A more professional training and a more formal employment were suggested to those seeking to work in the museum world as curators or conservators at the end of the nineteenth century, be it the École du Louvre (1882) or the universities. Nevertheless, some painters had played a prominent role in the evolution of national museums: after the revolution of 1848 the French painter Philippe-Auguste Jeanron (1809-77) imagined a very modern organization of the Louvre, which was followed by the 2 nd Empire and the 3rd Republic.

In the twentieth century, the curators under totalitarian rule had to choose to be dismissed, to emigrate or to fully adopt the agenda of their masters. This, definitely, applies to Germany: 'Museum directors, while possessing considerable erudition and even international renown, comprised one of the most nazified professions' (Petropoulos 2000: 14). In the museums under the rule of 'socialist realism', exhibitions served as a form of propaganda. In the Tallinn State Art Museum 'the emphasis of museum display was laid on Estonian art preceding the October Revolution (for example, limited to a few artists who had studied in St. Petersburg), and the works of art in the so-called Socialist Realist style' (Kuutma 2011). This moment is a monstrous illustration of the fact that art museums are always part of cultural policy, bringing into the public sphere a certain idea about aesthetics, and contributing clearly to the agency of art in the community.

In the second half of the twentieth century, the concept of avant-garde gave a new impetus to the national model of an art museum, inventing what has been coined as 'the tradition of the new' (Rosenberg 1994), each nation seemingly having a special position in the new history of art according to the ability of its artists to make innovations and to have a recognized influence in the field, in the context of a perpetual reinvention of the subjects, forms and attitudes. Depending on time and country, this definition of art has oscillated between cosmopolitism and universalistic affirmations and strong community-bounded and even ethnic assertions. The dispute among social scientists about the different types of nationalism and nationality elaborated on in Europe during the past two centuries is too well-known to be repeated here, but it is clear that the judgement upon the national quality of art works in each nation-state depends on such choices. Beyond 
the philosophical and aesthetic problems that such considerations involve, the question is linked to the protection of artworks, to their ownership and to the liberal exchange they may participate in within European culture, or within the landscape of blockbuster exhibitions and virtual museums.

This chapter considers first the identity of the national museum of art in the simple terms of ownership, related to the political issues of politics, policy and funding, and to the social context of private collecting and philanthropy. After that, the national collections are studied according to their aesthetic and cultural contents, from universally considered museum pieces to timely works. The architectural settings as well as the curatorial work of the catalogues and display constitute the third part of this chapter to explain the successive and sometimes conflictual interpretations of works of art during the process of their institutionalization and democratization. Finally, the uses of the national museums are dealt with by visitors as sites of appropriations, but they may also be seen as a means of disseminating art through mechanical reproductions for commercial purposes more or less related to the museums themselves. We will study their agency, between the apprenticeship of the artists, teaching the persuasiveness of high art to visitors, and celebrating the national spirit of their curatorship.

\section{Ownership}

The museum appears as the 'home' of art and knowledge, a place devoted to democratic access to pleasure and knowledge. However, the European museums have been anything but still. Beyond the permanent character of museum ownership, the national art museums can be seen during three centuries among the 'temporary stabilizers' (Hall 2001) of heritages related to different national communities. The entering of objects into the museum must be considered as the intertwined result of institutional history and the biographies of various actors - curators, donors, merchants (Hill 2005; Poulot 2012a). The museum world has always been dominated by heated debates on the issues of heritage and the ownership of culture: who can legitimately claim to own a great work of art - an individual proprietor, a culture, the nation or humanity? Another fundamental question is the entering of objects into museums, which more or less explicitly involves a rupture or specific phase in the long life of images and objects. The history of the museum was for a long time understood according to the glorifying logics of the collectors or, in contrast, as a narrative of reparation in relation to objects unduly seized and assembled.

The conquest of treasures in times of war is hardly something new, but is timeless and pandemic (Greenfield 2007). The contradictions between the meaning of an object in its environment and in its new location in a museum, which becomes the ideal depository and shelter of all artistic industries, became apparent in the first third of the nineteenth century - even if its premises were visible earlier, as in the case of the collections of the antiquities of the Italian peninsula, heavily bought up by foreigners, especially British collectors, since the early modern period. Discussions related to property and legitimacy were central in the 
formation of a collective culture of art, considered as a heritage of useful models for national schools of art, as much as for the progress of knowledge. The question of whether artworks are the property of princes, royal families or the state was crucial during periods of dynastic crises or revolutions and in any case at the moment of the elaboration of new nation-state structures. Such is the case of the Uffizi, recognized as the collective property of the Tuscan state during the succession crisis of the dukedom of Tuscany. In Sweden, the collection of Gustav III, bought in Italy during his journey in 1783-4 with state money, was after his assassination considered state property and was used for the royal museum opened in 1794 . The British Museum, founded by the Parliament, is singular in this context because it was from the beginning a public institution, not related to the royal collections or to a dynasty's property.

The revolutionary period was an essential moment for the constitution of Europe's great art museums, in consequence of the wave of confiscations of churches' and princes' properties (some of them having occurred already during the Enlightenment, especially under Emperor Joseph II). The confiscations of the French revolutionary armies from 1793 onwards played an essential role in the configuration of art collections in the new national museums in occupied countries. The decree of the French Minister for the Interior, Chaptal, in 1801 distributed works of art from the Louvre collection to some 15 to 20 museums all around the 'great nation', that is to say well beyond the traditional frontiers of France. A network of museums appeared in the new Napoleonic Empire, according to a model that was repeated and varied to adapt to different forms of territorial organization (Bergvelt et al. 2009). One remarkable case is the museum of Brussels, developed by the director of the Academy of Painting and Sculpture, Bosschaert, as a centre for the education and betterment of young artists (Roberts-Jones 1987). In Spain, Joseph Bonaparte opened a museum with paintings taken from suppressed convents and other church properties at the Museo Josefino in 1809, following the example of French revolutionary museums. These years saw also the birth of a contestation of looting, brought by a theory of heritage and a more or less sophisticated criticism of museums, notably with the famous Letters to Miranda written by Quatremère de Quincy.

There is a considerable difference between art museums in countries that were invaded or recomposed at different times throughout their history, and those in countries whose national and cultural frontiers remained closed. Still, everywhere the museums of the nineteenth century were at the heart of an international race for the greatest new collections, in particular on the archaeological front (Jenkins 1992), with the argument that the natural destination of ancient art was to revitalize the modern artistic production of their nations. In England, the Napoleonic Wars encouraged the promotion of patriotic art (the English/British School) and the acquisition of antiquities from abroad (the Elgin enterprise being largely supported by state means, even if it was supposedly a private speculation) in direct attempts to rival French cultural developments. The acquisition of the Parthenon Marbles was justified as the legitimate right of liberal Britain to own the heritage of Greek freedom (Poulot 2012b). 
In the mid-nineteenth century, some countries experienced a clarification of the status of dynastic property and public property as in the case of Denmark when the 1849 Constitution stipulated that the collections of the prince should become the heart of the new national museum in the royal palace. In France, however, the Spanish gallery of the Louvre disappeared with the 1848 revolution as it was considered to be the private property of Louis-Philippe. In Italy, after the reunification, the devolution of ecclesiastical assets began in 1866 - although some transfers of property had already been issued in 1861. An enormous number of ornaments (paintings, sculptures, books, etc.) were confiscated by the public authorities, which were forced to make rapid arrangements for their storage. In Naples, for example, the Museo Nazionale was enriched with numerous objects. In Florence, some of the paintings confiscated were transferred to the Uffizi, while other objects were exhibited in a new national museum, the Museo Nazionale del Bargello, a former jail (Allie 2010). The political cleavage between state and Church - provoked by the latter's refusal to recognize the new-born kingdom of Italy (of which the pope declared himself a 'prisoner') - transformed works of art into symbols of different and conflicting powers (Troilo 2005). No longer liturgical and devotional, they became key components of a secular and patriotic discourse based on the celebration of the fatherland and its glories.

The question of ownership has been regulated throughout a long history of transfers of cultural goods from one nation to another. The collections of the museums were seized in cases of conflict and then became the focal point of the politics of protection. From the 1870 Franco-Prussian war onwards, the administration of French museums has been concerned about how to protect the Louvre's collection in the eventuality of an invasion. In the twentieth century, the Spanish Civil War led to the development of new strategies for museum security: the masterpieces of the Prado were transferred to Geneva with the help of the Society of Nations, and they went back to Madrid in 1939 after Franco's victory (Colorado Castellary 2008). Finally, some returns turned iconic: after the recovery of democracy in Spain, Picasso's Guernica arrived from New York in 1981 and was installed in a dependency of the Prado to be later transferred to the newly created Museo Centro de Arte Reina Sofia as a powerful symbol of freedom and modern art (Holo 1999).

The lootings of the twentieth century, especially by the Nazis, were without precedent in scale and thoroughness. The purging of the so-called 'degenerate' works from the state collections in the summer of 1937 and the Haus der Deutschen Kunst in 1937 were the most well-known consequence of the Nazi Kunstpolitik. Before and during World War II, buying paintings under special conditions or just stealing them from persecuted owners, in forced sales, and also seizing masterpieces with the help of the army, or of collaborative regimes, as in the case of the Ghent Altar in Vichy France, were common practices. The plundering bureaucracy was intellectually legitimized by the Kümmel Report, which compiled a more than 500-page-long list of artworks of German origin (or works of art that had been removed from German collections since 1500) located abroad. 'The 
Nazis looted approximately one hundred and fifty thousand art objects in Western Europe and about a half million works in Eastern Europe' (Petropoulos 2000). The complex issue of restitutions to the previous owners is now a global concern, with US museums as deeply involved as European museums. Lastly the post-colonial context provides another case for the definition of a hierarchy of objects to be given back (Barringer and Flynn 1998). These restitutions are accompanied by specific rituals that are important for the values of a new appropriation, highlighting the specific role of 'ambassador objects'.

Some movements of artworks between museums are happily less dramatic: the phenomenon of the art exhibition - of the 'ephemeral museum' (Haskell 2000) has given rise to a specific discourse justifying the displacement of artworks, expressing the cultural importance that is attributed to these European 'grand tours' of the objects, which include capitals and major cities but may also offer a temporary presence in more peripheral zones. Inversely, certain objects are excluded from any loan system, by being endowed with a specific distinction, as they are considered attached to the site of their conservation. The formation of ephemeral collections has reconfigured the value of objects from the very beginning of such events, which took place in 1857 at Manchester (Pergam 2011; Macleod 1996).

During the fascist era, the manifestations designed to illustrate the greatness of Italian art flourished in museums and international exhibitions (Haskell 2000) - one such example being the celebration of Giotto in Florence in 1937. With the pursuit of an ideal of blockbuster exhibitions, the directors of some of the biggest national art museums throughout the world created during the last decades of the twentieth century, under the initiative of the French museums administration, the so-called 'Bizot Group' to operate lending and exchanges smoothly; some European museums now participate in the 'lending for Europe' project, which aims to facilitate museum object mobility. The new display of objects on these occasions reinforces the hierarchy of institutions in giving museum objects greater visibility. Exhibitions in mobile museums, which appeared in the middle of the twentieth century but have proliferated alongside the effort to expand the perimeter of the traditional museum by using mobile structures, have produced the same result (for instance the temporary Gallery of the Mnam-Pompidou, after the examples of some propaganda mobile museums of the 1930s).

The history of art museums considered as an history of collections has to be related to this other history of circulations: of the presences and absences of artworks in front of visitors. In the 1960s art historian Timothy J. Clark stood thinking, in front of Poussin's Landscape with a Man Killed by a Snake in the National Gallery, that the picture was then, partly, 'an allegory of revolution'. One generation later, in the Getty Museum of Los Angeles, in front of the same painting on loan, he said 'I look forward to seeing the painting back in its London place, across from the Bacchanal and the Golden Calf', and he wrote that 'Paul Valéry says somewhere that a work of art is defined by the fact that it does not exhaust itself offer up what it has to offer - on first or second or subsequent reading. Art-ness is the capacity to invite repeated response' (Clark 2006). These repeated responses are 
now framed by temporary encounters with the same artworks throughout the world, and by the poetics of their different places and displays. Even if the national ownership of masterpieces is inalienable, it becomes more liquid, and a new experience was born from the process of circulating exhibitions.

\section{The legacy of the civil society}

In many countries, the state had no real interest in, or plans for, the museum and cultural heritage sector. Many national art museums resulted then from collective or personal initiatives from the civil society, by collectors or societies of friends of the arts that were later recognized as being of public interest. In numerous cases, the different academies of art, or letters, history or antiquities had during the last decades of the eighteenth century been more or less in charge of collecting and making inventories of archaeological remains, artworks or art models for the grandeur of the country. Some art societies, such as the Kunstvereins, took over the charge of exhibition programmes in place of the academies. In Sweden, the Stockholm Art Association was founded in 1832, modelled on the German Kunstvereins that had emerged in the 1820s. The goal of the art association was to promote art life in Sweden from arranging exhibitions and buying art from promising young artists to the formation of a national art museum (Widen 2011). The engagement of artists towards the creation of a museum - principally in favour of a contemporary art museum - represented another form of involvement that could be aesthetic as well as political and patriotic. In Scotland, artists developed their own academy, supported by aristocratic and wealthy middle-class collectors, with a collection of old masters and Scots artists for training the new school as much as for appreciation. In the middle of the nineteenth century, inspired by developments in London and particularly as a result of the Great Exhibition, a kind of national gallery was developed from the Institution for the Encouragement of Fine Arts (founded in 1819 with a Royal Charter in 1857) along with collections from the Society of Antiquaries. Throughout the nineteenth century, the relationship between public and private property progressively came to define liberal ideology (Bailkin 2004; Taylor 1999).

According to the perspectives developed by anthropologists, inanimate objects take on life through their interpretation - notably as they are collected and housed in museums: 'An object becomes interpretable only in the context of a "society of friends" (Tamen 2009). Artworks as museum objects have been interpreted in an inseparable manner by amateurs, such as private collectors, or by art market professionals, and by those who are often perceived as their enemies or rivals: the curators of the museums - yet all of them in fact claim to be 'friends' of these objects. The case of one of the most famous museum directors in Europe, Wilhelm Bode (1845-1929), illustrates well the intersection of the private collectors' space and the curator's museum (McIsaac 2007). However, the private possessions of collectors could be the pretext for important confrontations with the national collection in terms of social legitimacy. In France after the Revolution, the collectors' 
bric-à-brac became the only way of accessing a bygone time, of holding on to a memory of the Ancien Régime that was contrary to the interests of official history.

The testament of the amateur Edmond de Goncourt constituted an archetype of the discourses that expressed a rejection of the museum principally by affirming that possession is the most intimate relationship that one can entertain with an object. Still, another testament, no less famous, the Caillebotte bequest of 1883 , opened the door for the Impressionists into a museum in France in 1896, when at least a part of this collection was accepted by the administration. In 1878 he donated his collection, on condition that it would be displayed in the Musée du Luxembourg, antechamber to the Louvre, writing that 'it is necessary that a certain time go by before the execution of this clause, until the public may, I don't say understand, but accept this painting. This time could be twenty years or more' (Caillebotte 1883; Long 2001). The Museum Council accepted the whole donation, but political and institutional fears of the opinion prevailed for a while. As on other occasions, it is difficult to separate the considerations about true art, or artfor-the-museum, valued for its quality and dignity, and political opinions about beauty and nationality. Hugo von Tschudi, director of the Munich Neue Staatsgalerie 1909-11, and formerly director of the National Gallery in Berlin, opened in 1876 to celebrate national art, was greatly responsible for introducing contemporary art in public institutions in Germany, from French artists such as Cézanne to the Berlin Secession. He was, however, fired by the kaiser in 1896. Nationalistic claims, moral choices, aesthetic tastes, as well as conflicts about the utility and the ideal of an art museum, explained his defeat in Berlin, but also his triumph in Munich, where he could mobilize private money to pursue his activity of public collector and amateur (McBride 2006).

Anyway, patrons of museums always hoped to gain in respectability by contributing to the growth of public collections, as well as wanting to educate national taste and promote their artist friends (Conlin 2000; Adam 2009). The activity of philanthropists in the development of the museums, whether desirous of benefiting from greater respectability or driven by other motives, reveals the permeability between the action of collectors and the curators of public museums, who often share ties of friendship as well as rivalries, meeting in the sales room of the auctioneer or in the rooms of the museum itself, publishing and reading the same literature. In certain respects, these ties can be considered as signs of the unclear dividing lines between leisure and professional activities, between private and public activities. In all cases, the fruit of private collecting has been the stimulation of art museums, the development of their collections and the often innovative turn of their artistic choices. On the other hand, the impossibility of such practices and philanthropy, as in communist countries, resulted in poor collecting, or even in ending the development of the institution, as in the example of the museums of decorative art linked to luxurious consumption.

In particular cases, civil society from beyond territorial borders could be involved, by calling on collectors (Volait 2009) or on communities located abroad, or quite simply because the community in question no longer rules over its 
territory (as was during a large part of the nineteenth century the case of the Polish museum in exile, founded in Rapperswil, Switzerland, in 1870 by Count Władysław Broel-Plater). Such is also the case of the museums that emigrants were called on to support: the Royal Association for the Promotion of Fine Arts in Scotland, which was founded in 1834 purchasing pictures via subscription, and for the National Gallery, 'soon attracted members overseas who appear to have been particularly fond of Scottish landscape painting' (Watson 2011).

Even in the twentieth century, the 'national' museum of art can be the result of the good will of a foreign collector: such is the Gulbenkian Foundation, today one of the two most important art museums in Lisbon. This collection was brought together in the 1920s in a building transformed on the Avenue d'Iena in Paris (Conlin 2010). In order to fulfil the project after the death of the collector, after long negotiations and the personal intervention of General de Gaulle, the complete collection was transported to Portugal in 1960. The actual building of the museum was inaugurated in 1969 and became a reference in modern architecture and as a consequence a sign of opposition to the Salazar's national aesthetics.

\section{Museum pieces}

The distinctive character of the art pieces collected and exhibited first by their proud possessors and then by the nation is at the centre of the renown of the museums. The art museum is part of a system of singularization that places a certain number of objects outside of the normal commoditization process (a process that nevertheless served to evaluate them initially) and transforms them into special pieces. The expression 'museum piece', although attached to a plurality of meanings in different European languages, preserves a normative core around a recognized quality according to the opinions of the three tribes of the field of art history: the connoisseurs, the critics and the academic art historians (Gombrich 1996). In search of the most beautiful works of art, national museums had to deal with the rarity of their material, which implicated the necessity of looking to earlier or prior collections as sources. In stark contrast to museums of national history that generally enjoyed a monopoly on their objects of interest, national art museums must, for obvious reasons, take into account other national as well as international competitors in a tight market.

A national art museum is mostly situated in the capital of each nation, and usually enjoys a privilege of superiority over other regional or local museums illustrating specific schools of art. Most of these central museums illustrate, by cross-sampling representative examples of all the kinds of national art, a collection of styles and inspirations that represents the art of the whole country. Still, the most famous art museums are directly placed in an international context that goes largely beyond a national or even a European scale. All these museums were visited by international tourists and scholars because they were generally essential to a Grand Tour, or to the writing of a universal history of art from national, but also regional and transnational works of art (Storm 2014). The 'national' paintings or sculptures 
exhibited in the museums reveal how the institutions can diffuse a set of values for example images of domesticity, family, or patriotism considered as symbols in the nation-building process (Macleod 1996).

National museums of art are, in fact, full of regional artworks, and of examples of regional schools of art inside each nation - the representations of regions, of 'petites parties', of Heimat, are essential to the building of an image of the nation. In nineteenth-century France, paintings of Brittany, for example, were part of the general image of the nation and must enter the national museums. In 1898, in Paris Salon, Charles Cottet (1863-1925), who was raised in the Savoy, exhibited Au pays de la mer, a triptych with 'Ceux qui s'en vont', 'Le repas d'adieu' and 'Celles qui restent.' Gabriel Mourey, director of L'Art décoratif and the Parisian correspondent for The Studio, praised this depiction of a significant moment of Breton folk life 'as an image of the local Volksgeist' (Van Santvoort et al. 2008; Storm 2009). The curator of the national museum of modern art at the Luxembourg, Léonce Bénédite, acquired it because these paintings of Breton communities 'remove the distance between the people from today and their distant ancestors and show that $[\ldots]$ these maritime races have preserved their former character intact' (Augusteijn and Storm 2012). The three paintings are now at the Orsay Museum. In Iceland, 'important themes in the National Gallery's collection of early 19th-century Icelandic artists are national landscapes, heroes both from the time of the first Norse settlement and from the Icelandic national and cultural independence movement in the 19th century, as well as motives from the Saga literature, popular narratives, religion and myths' (Kvaran and Kristjánsdóttir 2001). This list works well for all the nations that have developed a more or less clear definition of national art with an iconographic repertory. In other cases, as for example in the Tate Museum, the collection refers to the donator's 'national' taste for 'moral situations and scenes' (Taylor 1999).

Interestingly, the genre of portrait relates equally to the art museum and to a national identity museum, because it offers a mix of interests, historical, artistic or aesthetic, which are often difficult to balance. Of course such institutions have inherited a long tradition of collections of portraits of the illustrious or of the members of royal families, or great men, as defined in the Enlightenment. In Sweden, the National Portrait Gallery of 'merited citizens' opened at the palace of Gripsholm in 1823. 'Presumably the first national portrait gallery in the world, it drew on a tradition of Gripsholm being a palace with a large collection of portraits that had been more or less publicly available since at least the 1720s' (Widen 2011). A similar purpose lay behind when, some thirty years later, the British National Portrait Gallery was founded (Pointon 1993).

\section{Universal and national: the artists of a national museum}

A long tradition of catalogue publication began with the creation of the first museums, as numerous artists and scholars worked to illustrate the quality of its resources. These publications 'would record, classify, elucidate and publicize collections of art [ $\ldots$ and reflected increasingly powerful nationalistic considerations' 
(Waterfield 2000: 71). The inventory catalogue, the expository guide and the presentation volume have until today been the three principal modes of these productions. With these instruments, art history, as a discipline that appeared during the second half of the nineteenth century and most particularly in German universities, relied mostly on the museum, at least since the first art historian Gustav Friedrich Waagen (1794-1868) became a museum director in Berlin in the 1830s.

Ever since the origins of museums, the organization of their collections according to national schools and pendants systems (by Pigage and Mechel for Düsseldorf in 1778, by the same Mechel in Vienna in 1781, or by Lanzi for his Pictorial History of Lower Italy in 1792) established de facto their nationalization. National qualities were subject to comparison and to a hierarchy of judgement, even though it concerned stylistic categories rather than geographical provenance (Kaufmann 2004) or historical development (Meijers 1995). In France during the revolution the idea was to divide the national collections into two parts, one reserved for the French school, the other for foreign schools, one based in Versailles, the special museum of the French school (1793) and the other in the Louvre. It was only when it became clear that this would marginalize the national school that it was decided to reinsert the collection into the Louvre, then conceived as a universal museum. In the end, the Luxembourg museum was turned into the home of the modern French school in 1818, putting the contemporary artists in competition in an 'Olympic museum' (Émeric-David 1796).

Some other examples prove the difficulty of this divide, and during the nineteenth century strong opposition was often at play between universalistic orientations and the pride of a national specificity in art. In 1836, the Norwegian Parliament formally established a national gallery of art, which was opened to the public in 1842 to display international artworks. Round about 1850 the board of the gallery, however, changed the aim towards collecting pieces by contemporary Norwegian artists. In Serbia, in 1868, the art collection of the museum was split into two parts: the first being dedicated to the 'artworks of foreign artists' and the second to 'exclusively Serbian artworks'. Another example is the original Tate, founded in 1879 by refiner Tate, which was uniquely dedicated to English art from the outset until 1926, when a new gallery for modern international art was added (before the Tate Modern, conceived in 1992).

Privileging a collection of national artists was a recurrent idea in the history of European national museums with the process of nationalizing artists as an absolute necessity in the nation-building process. One of the most obvious proclamations of this principle was formulated in 1835 in Brussels, stating that a national museum should be 'exclusively dedicated to Belgian's most remarkable painters, sculptors, engravers and architects' (Roberts-Jones 1987). This was part of a complete national cultural policy with the organization of an artistic salon, the preservation of historical monuments and the foundation of a royal commission for a series of statues representing Belgium's greatest men. All Flemish art was nationalized - 'van Eyck, Rubens and all the other great masters being naturalized as Belgians' (Loir 2001) - and the dispersion of the Flemish school was seen as a national disaster. 
Here, all the elements of a new historical invention of a 'national art' were reunited around the ideas of heritage and the museal equipment. In Luxembourg, the fine arts section of the museum underlined the importance of Luxembourgish artists in the collection, carefully specifying how these were defined by the museum: included were artists of Luxembourgish nationality, or born or married to members of a Luxembourgish family, or residing in the country for the greater part of their lives. All these administrative inventions created more or less everywhere a partition between two museums, one devoted to the art of 'ourselves' and the other to the art of 'the others'.

In some countries, 'a sense of unease about the quality of the native school' could make the national museum look like 'a fortress of national art' (Waterfield 2000). It could be understood as a feeling of acknowledged inferiority to more glorious national schools, or at least as a sense of insecurity in comparison with other achievements. The 'tacit avoidance of obvious competition', and the decision of 'giving the national school a unique standing, finally enshrined in a museum of its own, safe from competition', as Giles Waterfield described the English situation, is also 'a solution adopted by Russia, Poland and Hungary'. Other countries have sometimes posited a single artist as their main symbol of cultural identification by identifying the national museum with a museum devoted to one particular national artist (Belting 2000). Some great museums displayed some artists regarded as national in specific rooms, to make them clearly appear as national icons, or as a sort of 'identity card' for the nation. In Spain, 'on the occasion of the third centenary of Velasquez's birth in 1899, the central Oval Room was transformed into Velasquez's Room, contemporarily with the inauguration of a statue to the master in front of the main entrance to the museum' (Portus Perez 2009).

In Norway, 'the museum building was enlarged in 1904-7, 1918-24 and finally in 1937 with a separate gallery for the art of Edvard Munch' (Amundsen 2011b). The Estonian Museum was created with the purchase in 1912-13 of 80 sculptures by 'the renowned Estonian artist August Weizenberg' (Kuutma 2011). In Iceland, an important part of the National Gallery collection was devoted to the works by Ásgrímur Jónsson (1876-1958), who mainly painted Icelandic landscapes and illustrations of Icelandic sagas and popular folk tales, which were originally donated to the Icelandic nation for a separate museum inaugurated in 1960 (Amundsen 2011a). In some cases, the museum may bear the name of the artist, as in Lithuania with its museum devoted to the symbolist painter Čiurlionis (1875-1911), canonized as a national genius in the interwar period. The idea to establish an art museum was inspired by the first exhibitions of Lithuanian art and the activities of the Lithuanian art fellowship in early twentieth century. In 1921, the Constitutive Assembly decided to construct a M.K. Ćiurlionis gallery near the Art School, and organized the anniversary exhibition of his works in 1925. In 1930, the decision was made to build a new museum to celebrate the 500-year anniversary of the Grand Duke of Lithuania Vytautas the Great: it was finished in 1936 and took the name of the Vytautas Great Museum of Culture. But in 1944, the museum became the M.K. Ciurlionis State Museum of Art, and eventually the M.K. Čiurlionis National Museum of Art in 
1997 (www.ciurlionis.lt). The artist was called in the mid-1980s 'the most important keeper, depositor and representative of the national art and riches of art which exist in Lithuania' (Rindzeviciute 2008: 56).

In opposition to such affirmations of identity, new installations of national art museums currently tend to plead in favour of a greater complexity for the construction of a more global art history. In Estonia, the KUMU Art Museum 'seeks to overcome the historical dichotomy between national and Baltic German and to stress the importance of territoriality and plurality' (Kuutma 2011). Nevertheless, trying to move from the traditional agenda is not always easy. In 2003 the Norwegian State established its National Museum of Art, Architecture and Design to 'raise the level of knowledge about and commitment to the visual arts, architecture, the decorative arts and design, develop critical faculties, stimulate new perceptions, increased historical consciousness and tolerance of diversity' (www.nasjonalmuseet. no). However, the collecting and exhibition policies of the new national museum were vividly and quite critically discussed, because the museum's new policy did not refer to a specific national canon of artists or artistic works or to Norway as a nation at all.

\section{Timely works}

In most cases, surpluses or overcharged collections lead national museums to develop new hangings or to create new museums as prolongations of already existing institutions. Some of these mostly chronological divisions seem to be the product of practical considerations. The French case offers a clear scenario, as illustrated by Orsay and the 1848-1914 sectioning off from the Louvre. But the creation of a modern art museum is something different, related to the desire to partake in modernity.

The idea of a museum of present art is as old as the creation of museums, because it is supposed to make the national school develop and overcome other schools through profitable emulation. However, the contemporary history of this kind of museum in France, like in other countries, is that of a divorce between modernity and the state, supposedly resolved only through a refoundation of the national museum. It was the case in Paris after 1945, in the purpose of reconciling 'Genius and State', to use the words of Jean Cassou, a writer, art critic, poet, member of the French Resistance during World War II and the first director of the Musée National d'Art Moderne in Paris. In Spain in 1952, the Museo de Arte Contemporáneo was created on the initiative of a group of young artists. This museum throve in the 1960s and 1970s, when the efforts to modernize Spanish economy had started to bear fruit (Lorente 2011). The Galleria Nazionale d'Arte Moderna in Italy suffered a similar destiny until the inauguration in 2010 of the Maxxi, which the prestigious architect Zaha Hadid had been called upon to design, signalled a renewed appeal to international creation.

All these contemporary art museum openings were generally a means of manifesting the integration of a country and of its national school into a larger 
movement with the aim of ending an old-fashioned artistic isolationism, linked to a traditional view of nationalism. In Serbia during the period between the world wars the agenda was to promote the idea of Serbs and all South Slavs as a modern, civilized European nation. The Museum of Contemporary Art was founded in 1929 in order to 'keep paintings, sculptures and other objects of a similar kind, both foreign and national, that belong to contemporary art' (Popovic 1991). This museum played an important role in the Europeanization of Serbian and Yugoslav identity by organizing temporary exhibitions of a great many artists coming from the West, but also representing the Yugoslav art scene as an integral part of the European. In Turkey during the 2000s, fine arts museums emerged for the first time for an elite urbane clientele following European cultural norms and were hurried in order to precede Turkey's bid to accession talks with the European Union. 'Probably the most internationally visible and using the most nationalist rhetoric has been the Istanbul Modern Museum of Art, which claims to attract half a million visitors a year' (Shaw 2011). The case of Cyprus manifests today an obvious divide between generations and artists, between those who aimed at strengthening national identity above all considerations and the others.

Still, the most exemplary case of a museum of modern art playing its part in the building of an iconic image of a nation was the Moderna Museet, the museum of modern art in Stockholm, a 'museum that meant the most when it came to nation building and Swedish self-image in the second half of the 20th century' (Bjurström 1992). When the museum was inaugurated in May 1958, its most important aspect was the policy of public participation and democracy (with a pioneering children's activity programme and a children's workshop). The idea behind the Moderna Museet, which was about involving people, citizens, also permeated the Centre Pompidou under the same director, Pontus Hultén, whose objective was also to put France on the international landscape of modernity.

\section{Settings}

The architecture and the decor are often underestimated by historiography, despite being essential to the identity and purpose of the art museum. First, national art museums were settled inside castles, and their decor was not different from the palatial inspiration or from the state rooms of the national residences. The situation changed with the first buildings especially dedicated to the use of museums (Pevsner 1976; Giebelhausen 2003). In nineteenth-century France, the model of the Louvre was preeminent, with the great Gallery and the Salon Carré, while other national museums were settled in a series of converted churches or monasteries. The Crystal Palace, a famous cast-iron and plate-glass building originally erected by Joseph Paxton in Hyde Park to house the Great Exhibition of 1851, and its byproduct, the South Kensington Museum, initially known as the Museum of Manufactures (1852, Somerset House), moved in 1857 to South Kensington and renamed by Queen Victoria in 1899 as the Victoria and Albert Museum, were the first examples of this narrow link between architecture, decor and new purpose. In 
the twentieth century, the New National Gallery at the Kulturforum in Berlin, designed by Ludwig Mies van der Rohe and opened in 1968, the Musée National d'Art Moderne in the Centre Pompidou (named after the President of France who commissioned the building), designed by Renzo Piano and opened in 1977, or the Tate Modern (2000), designed by Herzog and de Meuron through the adaptive reuse of the former Bankside Power Station, were also landmarks of artistic authority and suggested new scenarios for the history of art.

During the nineteenth century the relationship between the ruler and the architect was instrumental in the building of a national museum of art. Such was the connection between Friedrich Wilhelm von Humboldt (1767-1835), the Prussian philosopher and founder of the University of Berlin, Friedrich Schinkel, the court favourite architect and artist, and King Friedrich Wilhelm III for the Altes Museum in Berlin. A similar interplay was evident in the construction of the Munich Glyptothek, which was commissioned by the Bavarian King Ludwig I to house his collection of Greek and Roman sculptures, designed by Leo von Klenze (1784-1864), the court architect, in the neo-classical style, and built from 1816 to 1830 . Similarly, Louis-Philippe, in the 1830 s, came nearly every day to discuss with his architect Eugène-Charles-Frédéric Nepveu (1777-1862) the progress of the celebrated Gallery of Battles, modelled on the Grand Gallery of the Louvre, in the new museum of history (dedicated to 'All the Glories of France') in the Versailles Castle. To mention, eventually, an infamous example, Hitler also made time in his busy schedule for Hans Posse, director of the Dresden Gemäldegalerie (1913-42) and for architects to plan the Führermuseum to be constructed under his own guidance at Linz in Austria to control and use art as an instrument of political will and power (Puloy 1998).

At the beginning of the nineteenth century some French professors of architecture were instrumental for the neo-classical museum buildings all over Europe. One archetype of public museums was a symmetrical building with four inner courts and with a rotunda in the middle, providing good lighting of the exhibition, as JeanNicolas-Louis Durand (1760-1834), a former collaborator of the architect ÉtienneLouis Boullée and a professor of architecture at the École Polytechnique, imagined it, by the use of simple modular elements, in his influential architectural handbooks. A great number of the monumental new buildings of the nineteenth century, such as the Alte Pinakothek or the Dresden Gemäldegalerie, followed a common disposition, that is to say a 'configuration oriented around large galleries outfitted with skylights which are abutted by smaller cabinets' (Digout 2009). These most successful architectural models were more or less easily adopted throughout Europe. The Russian Emperor Nicholas I called von Klenze in 1838 to design in this way a building for the New Hermitage, a public museum that housed the Romanov collection. This general plan was linked to the necessity of providing a natural light, a central element in the design of the rooms of any museum. The architect and professor Julien Guadet, of the French École des Beaux-Arts, gave lectures at the end of the nineteenth century about the best museum design from precise calculations of the glass surfaces and of the openings of the roofs (Guadet 1901). At that moment, 
other styles than the Greek revival could appear in some national museums, according to new fashions and historicist trends. In Switzerland, Gustav Gull constructed the national (federal) museum in Zurich between 1892 and 1898 after two models, the Musée de Cluny in Paris and the Germanisches Nationalmuseum in Nuremberg. This museum was based on the plan of a late medieval to early Renaissance castle and may be described as a composite building, which used as many authentic and antic elements as possible.

In most of the national museums of art the decorative details played a considerable part for the legibility of the art displayed inside, through their mobilization of historical myths, and their exaltation of an aesthetics of the ideal. This goes especially for the German nineteenth-century museum decoration such as the Peter Cornelius murals in the Alte Pinakothek in Munich, which provided simultaneously a history and a theory of art. Sometimes after, 'Wilhelm von Kaulbach's monumental decorations in the Neue Museum in Berlin shifted from the history of art to a world history of civilization and religion' (Grewe 2012). In England, Owen Jones, the 'Grand Polychromatist-plenipotentiary' and perpetrator of bad taste, according to the Blackwoods Magazine in September 1854, was an actor at the South Kensington Museum, in the global migration of design motifs, 'through a network of taste arbiters, the pages of a ground breaking design manual', and the display of domestic design productions of furnishing textiles and wallpaper (Ashmore 2008).

The construction of some monuments has given certain capitals a marked museal identity. The Viennese case is particularly remarkable, with the walls and fields of the fortress being razed after 1857, making it possible for the city centre to expand. In their place, a broad boulevard called the Ringstraße was built, along which imposing public and private buildings, monuments, and parks had been created by the start of the twentieth century: the Rathaus (town hall), the Burgtheater, the university, the Parliament, and the twin Kunsthistorisches Museum and Naturhistorisches Museum. In this particularly disputed location the imperial power was expressed through an artistic culture honouring the baroque dynastic tradition (Schorske 1980). Another exemplary foundation of museums was provided by the case of the new Greek nation, where King Otho (the son of King Ludwig of Bavaria) commissioned the architect Leo von Klenze to draw up plans for the restoration of the Acropolis. During the second half of nineteenth-century, the display of archaeology as history of art with the emphasis put on aesthetics in the Greek museums appeared as 'a reflection of intellectual colonialism imported from German classical scholarship' (Gazi 2011). During the first decades of the twentieth century, the ideal of art museums conceived as sites of 'collective experience', sometimes on a Bauhaus inspiration, appeared. In this sense, some museums of art became a kind of Gesamtkunstwerk, that is to say a 'total work of art' or 'unified work of art', to refer to an art museum as an exhibition of experience.

The great English historian of architecture, Sir Nikolaus Pevsner, claimed in an overview of the building types in the 1970s that museum architecture had not developed any significant new types since World War II and that 'no new principles have turned up'. But in the last decades of the twentieth century, there were more 
or less obvious tensions between new installations and the heritage of older art museums and their institutions. The Beaubourg Centre in Paris, a model of hightech architecture designed by Rogers and Piano, has been a turning point in the history of European museums, manifesting the desire of President Pompidou to reinstate France on the stage of international modern art. A generation after, all national museums of art in the European capitals have been more or less entirely refurbished and redeveloped, the new parts oscillating between tradition and rupture.

Art museums have always had complex shifting relations with their environment, because they offer a valuable set of open opportunities for appropriating the sense of art and heritage. Concentrating museums in some locations of a capital was a traditional way to develop the institution, such as the Louvre quarter in the Ancien Régime, or 'Albertopolis' in nineteenth-century London, which reunited a lot of different museums, schools, shops and academies. Today, a great many centres of European capitals are more or less museified, and the result is that the architecture of the new parts of national museums must be very respectful of the style of the previous buildings, for obvious reasons. An example of respect for the past is the Grand Louvre by Chinese-American architect Ieoh Ming Pei. Another one is the Grand Duke Jean Museum of Modern Art in Luxembourg City, which stands on the site of the old Fort Thüngen, a Vauban monument, and was designed by the same architect in 2006. In London, the fierce debate of the 1980s and 1990s that, due to the intervention of the Prince of Wales, was solved in Robert Venturi's Sainsbury wing opened a new post-modern path (Calder 2009).

In the same way, the MuseumsQuartier in Vienna today presents an astonishing range of styles ('Baroque Meets Cyberspace'), spanning from baroque eighteenthcentury buildings to the almost white shell limestone façade of the Leopold museum completed in 2001 by Austrian architects Manfred and Laurids Ortner. The creation in Amsterdam of a Museum quarter - home to the three major museums, the Rijksmuseum, the Stedelijk Museum of Modern Art and the Van Gogh Museum - as well as the completion of the museum quarter of the Prado in Madrid, or of the programme of renovation always on the move of the Museums Insel in Berlin are all examples of a second age of national art museums in contemporary Europe. They testify to the importance of investments in new buildings and to the refurbishment of older ones in order to create a new touristic experience. In such operations, one may be afraid that star architects could trump collections with their buildings, but in Berlin David Chipperfield succeeded in restoring the Neues Museum - built between 1843 and 1855 by August Stüler a student of Karl Friedrich Schinkel - as a monumental palimpsest.

Some other European museums are not national ones, at least officially, but they are part nevertheless of the 'national' image of a community, and even build it very effectively. The Guggenheim Museum Bilbao, a museum of modern and contemporary art, designed by Canadian-American architect Frank Gehry and inaugurated in 1997, is now a brand image of the Basque Country. The dispute about its creation between the local artistic traditions and a branding agency was a clear symptom of a new situation about creating and practising locality (Appadurai 1996). 
Its image became de facto a Basque one, and perhaps the most famous one, even if it was impossible to relate its collection to the values of a community as they are traditionally understood. One observes the same process in some cities, during the 2000s decade, with new museums which try to emulate its success, such as the branch of the French National Museum of Modern Art, designed by Japanese architect Shigeru Ban and inaugurated in 2010 as Pompidou-Metz, or the second Louvre located in Lens, Northern France, approximately 200 kilometres north of Paris and opened in 2012 (designed by two other Japanese architects, Kazuyo Sejima and Ryue Nishizawa). These museums publicize themselves in the media worldwide and are part of networks of tourists and scholars on a global scale.

These examples demonstrate that the former identity of these national museums is probably fading for the benefit of the image of a new metropolitan culture. These museums are now mobilized for the branding of their cities in a cosmopolitan market of artful experiences for global tourism. They are also competing in the sphere of connoisseurship, knowledge and academic research in art history throughout the world in publishing, cataloguing and displaying old and new art. In Paris today the roof of the new galleries of Islamic Art of the Louvre Museum, opened in 2012, was designed by Mario Bellini and Rudy Ricciotti as a kind of response to I.M. Pei's pyramid of 1989, as a strong gesture between the glass curtain and the gold screen. The relation with the Global Louvre project to be opened in Abu Dhabi in 2015 by Jean Nouvel is clear: the 'seductive screen [ ... ] appears to have landed at the Louvre transporting aesthetic associations, as well as economic possibilities, characteristic of contemporary architecture in the Gulf (Roxburgh 2013). It is also as an empowerment of studies that the new department is evaluated and judged, and the lengthy discussions about its name and the use of the term 'Islamic art' as a taxonomic currency, against repeated attempts to change it, are a testimony of the influence of a national museum of art on the art market and academy.

\section{The uses of the museum}

The first use of the art museum of the eighteenth century was clearly the education of artists - or what we might designate as the administration and business of art. It was designed to provide, in the context of a renewed classicism, universal models such as those furnished by antiquity. It was narrowly related to a place of work, became an essential tool for the education of the artist, and its objective was to develop specific schools of art, essential to express the identity and pride of the nation. Still, in fact, the definition and the purpose of the national museums of art were often difficult to distinguish from those of the other national museums, of applied arts, of history, etc. The case of industrial or decorative art was peculiarly striking, because a kind of homogeneity in their museums was evident throughout Europe (Arlaud 2008; Rampley 2010). Even the national ethnographic museums had 'a triple function, which was regularly repeated by their organisers': a patriotic function in favour of national traditions, spirit and lifestyle, a scientific function to 
conserve and protect the materials of traditional culture, 'just before their extinction', but also 'a function for the applied arts: they were meant to provide artists and artisans with models and motifs to feed modern creativity' (Thiesse 2012).

In the nineteenth century, it was expected that museums illustrated a progress of the taste of the nation and the growth of the quality and success of its industries. In 1836 the parliamentary select committee which investigated the organization of the National Gallery in London was studying 'the best means of extending a knowledge of the arts and of the principles of design among the people'. It wanted to "emulate the example set by Germany and France in satisfying the desire among "the enterprising and laborious classes" for "information in the Arts" (Waterfield 2000). In Poland in 1862, a comprehensive reform of the education system was carried out by the tsarist-backed Government Commission for Religious Affairs and Public Enlightenment.

At the opening to the public in 1865, admittance was free of charge, exhibitions were developed along didactic lines: chronological order was followed, with strict divisions into art schools and solely foreign art was on display. The didactic rationale also found its expression in the presence of copies of famous works of art, which the museum did not possess.

(Mazan 2011)

However, there was another possible philosophy of the art museum which played a prominent part at the end of the nineteenth century. As early as 1828 the Prussian architect and painter Karl Friedrich Schinkel (1781-1841) and the art historian Gustav Friedrich Waagen had written about 'the purpose of the Berlin Gallery': 'First delight, then instruct'. It was a turning point of the 'conventional formulation' (Paul 2012). With this new challenge, the ideal of a collection of useful models and copies was to be eclipsed by another one, all about original pieces of high art and history, which took the first place all over Europe around 1870-80. One can see here more or less the appearance of the 'two distinct models for the exhibition of works of art' that the American literary scholar Stephen Greenblatt called resonance and wonder. The first refers to 'the power of the displayed object to reach out beyond its formal boundaries to a larger world', to make evocations, and the second alludes to 'the power of the displayed object to stop the viewer in his or her tracks' (Greenblatt 1991). In fact, according to the English museum director Neil McGregor, every major public collection tries to keep a balance 'between a museum, like the British Museum, where specimens are put together to reveal a progression or a pattern, and a gallery, where the individual work of art is meant to be seen and enjoyed on its own' (Cuno 2004).

In all cases the museum curators tried to understand what impact the contemplation of art might make on the visitor and how museums might weigh in on the balance of public taste or develop certain competencies (Kesner 2006). In a similar vein to the question of public literacy, the museums made enquiries into how to mould character, reform taste, inspire a sense of emulation and elevate 
minds. The literature dedicated to the question of persuasion, conceived as the power of museums (Stankiewicz 1984), tried to study how the display could give rise to sympathies, attachments and benevolence towards art (Edwards et al. 2006). Of course, all nations cultivated specific hopes for their institutions, the German elite being perhaps more convinced than others that 'from the contemplation of the history of art, people would receive both moral instruction and civic virtue' (Sheehan 2000).

This literature must be considered in the context of the discussions of taste and morality that could be found in a variety of formats like travel diaries, biographies or sermons. The idea of an attachment to the objects was orchestrated and represented in a literature that was at once descriptive and prescriptive (guides, narratives of visits, catalogues, curators' literature, etc.). All were essential to understand the emergence of the museum as a public resource. An extraordinary number of novels, poems or plays devoted to this topic in the course of the nineteenth century were complemented by various forms of criticism about curiosity and art collecting, in particular, as well as collectors' writings, such as autobiographies and correspondence. Such artistic literature was seminal in the creation of the 'friend of art' as a social type in elite as well as popular imagination.

From the nineteenth century onwards, the museum visit has been regulated by a new set of behavioural imperatives - self-control, attentiveness, silence and immobility - differentiating the visit from older practices, as in other forms of entertainment and public spectacles (Crary 1999; Stankiewicz 1984). Some colour theorists, psychologists and diverse kinds of scientists, as well as artists, exerted an influence on museums, especially in Germany, with people such as Wilhelm Wundt from the scientific, and Bode or Justi from the curators' side (Klonk 2009). The development of urban leisure, in the form of the flaneur strolling and taking in shop window displays, surely had an influence on the development of a specific kind of museum gaze (Shaya 2004). Still, so did the caricatures and humoristic images that abounded in more or less specialized journals. There were also differences between types of visitors; in some instances visitors belonging to the elite were allowed to touch the objects, a behaviour that was justified and considered as correct, while the same gestures were forbidden when attempted by lower social categories (Candlin 2008).

The discourse of and about the art museum had strong political implications, as has been shown in Britain with the question of municipal investments and the professionalization of curators (Hill 2005). A great many social reformers praised the values of the museum as a place that allowed visitors to be inspired by the most elevated ideals. The visit to the museum thus became the subject of positive expectations, more or less justified and explained. But in a period rich in expectations about the correct way to envisage the cultural ideals, a certain apprehension about some of the possible misappropriations of museums by the masses also appeared. The affirmation of the value of museums was questioned by different members of the public such as collectors who felt that the social life of the object was endangered by the museum-piece status, and who considered private 
appropriation as superior (Dudley et al. 2012). Different criticisms of the institution were also levelled by economists, philosophers and political scientists during the public debates that began to take place considering the uses and abuses of museums. The museum was therefore referred to political theory, to the notions of individualism and liberalism, philanthropy and public institutions. The title of the famous article published in 1883 by the English philosopher and economist W. Stanley Jevons, 'The use and abuse of museums', showed the emergence of an interrogation into the economy of culture as related to political science and to organizational theory. A discussion concerning the legitimate use or the excessive development of museums began to spread all over Europe.

One century later, some curators wanted to combine vanguard artistic innovation with audience engagement: the best example in Europe, even if it is not, strictly speaking, a 'national' museum, considering the specific history of Netherlands, is the Stedelijk museum in Amsterdam after the Second World War (194562). Its famed director, Willem Sandberg (1897-1984), developed a strong commitment to democratize modern art, and introduced for example audio guides for viewing galleries. The practice of culturele weekendjes spent in Amsterdam with seasonal discounts on trains and museum membership became common among citizens, which produced a 'special relationship' between the nation and its first museum (Reisz 2013). Another kind of politics of art museums was the orientations of collections in communist countries. Such is the case of the African art museum opened in May 1977 in Socialist Belgrade for 'a more global understanding of history and culture, man and society'. This struggle against 'eurocentric and ethnocentric beliefs, cultural prejudice and narrow mindedness' (ManojlovićPintar and Ignjatovic 2011) was probably a distant inheritor of the philosophy of the usefulness of the museum forged during the Enlightenment, but it was part of the Third World philosophy promoted in the framework of the Cold War.

The question of the visitors to European art museums became a vexed one during the critical turn of the 1960s. In France, the sociologist Pierre Bourdieu, in his influential The Love of Art, attacked the art museum as a de facto fortress of its customary visitors, privileged by their cultural capital (Bourdieu and Darbel 1991). As the American art historian Carol Duncan summarized it, "What we see and do not see in art museums - and on what terms and by whose authority we do or do not see it - is closely linked to larger questions about who constitutes the community and who defines its identity' (Duncan and Wallach 1980). The thesis was largely reproduced and developed in the literature of museum studies of the next generation. Another criticism emerged in the post-colonial context, when the situation of colonial art in the national museums of art was criticized as marked by bias and prejudice.

To some commentators in Great Britain 'the exhibitions and collection displays at Tate effectively operate as the gate-keepers of an established British art-historical canon', contributing to the 'virtual invisibility of colonial art in British art museums today' (Thomas 2013). This statement could be largely extended to many national museums of art throughout Europe, where the defence of high quality of art is 
sometimes an alibi against a new examination of the collection, or against a revision of the display. It is more or less common sense today that 'the presumed national story of a heritage, the patrimony that smoothly hands down stories from father to son, must be accounted for through a visuality that brings certain images to the fore while leaving others unimaginable' (Dibosa 2008). In these conditions, the duty of the historian is to make clear that the museum experience is 'a constant negotiation of values and meanings' (Duncan 2002).

\section{Cultural (re)production}

The copy has always occupied an important role in schools and art academies across Europe, for pedagogy, as well as for art history. In the 1840s the 'Corner Room' painting gallery at the New Hermitage was designated as a space for training artists to copy Old Master paintings. Copying functioned as a heterotopia of the museum, as a compensation for immovability and regulation (Vermeulen 2010). The first museums from the end of the eighteenth century contained chalcography workshops, followed by printing and plaster copy workshops and factories (Falser 2011). The initiative by the history painter Samuel Morse to reproduce all the major masterpieces in the Louvre, in order to establish an art school and the basis of solid connoisseurship in the United States, is perhaps the most significant example of the hopes invested in the reproductions of the museum pieces.

Many art museums remained during the nineteenth century as a workplace and a source of livelihood for a great number of the humblest workers in the world of art, the copyists. The production of copies was then a quasi-industrial activity, taking on different forms; it was also the most obvious sign of any museum's productivity, the corollary of any attachment to a successful museum piece. In 1837, Karl Friedrich Schinkel hoped 'that recent inventions and improvements enabling works of art to be duplicated faithfully, easily, and safely may properly be used to give industry a direction in which beauty is as important as utility'. He did not regret 'the mechanical process that turns the artist's attention increasingly towards the intellectual element in the production of a work of art' and thought that 'if the knowledge of that work need no longer be acquired solely in museums or in those private collections to which access is difficult, then we may hope that here and there one of the seeds thus broadcast will take root and eventually bear fruit'.

If some nineteenth-century art museums were filled with numerous copies, later on, the copies became more or less clearly unworthy of the museum (Fyfe 2004). The best example was perhaps the case of the South Kensington museum, opened in 1857, of which Cole was the first director from 1857 to 1873, and which in 1899 became the Victoria and Albert Museum. A continuous model for all museums of industrial or applied arts, it wanted to foster interest, not in classical antiquity as represented by the British Museum, nor in masterpieces of Western European art as at the National Gallery, but 'in the products of contemporary British industry, in genre painting, and in new technologies, such as photography' 
(Baker and Richardson 1997). National art museums were supposed to aliment the progress of a science of objects that 'the empire of things' needed, and that could be part of a mid-Victorian 'Grand Design'. In fact, the V\&A museum always balanced 'a notional service to design and industry with a commitment to art historical scholarship' (Barringer and Flynn 1998), between the utilitarian Henry Cole, its first superintendent, and his colleague J.C. Robinson, who was devoted only to objects of the greatest merit.

Making and selling reproductions of museum pieces offered an opportunity for business. A great many reproductions were made for commercial purposes (Rionnet 1996), such as the reproduction of medieval furniture from Cluny that was sold throughout nineteenth-century Paris (Effros 2008). New techniques and the rise of the art market resulted in a wide distribution of reproductions to the general public during the second half of the nineteenth century (Verhoogt 2007). The famous Goupil merchant house in Paris (with branches throughout Europe and across the Atlantic) intended to create a salesroom modelled after the Salon Carre in the Louvre, to give an official and museum-like allure to the exhibition of copies. The process of duplication and appropriation was common everywhere, at different levels. For example, in 1902, celebrating the glory of the poet Hendrik Tollens (1780-1856) as a national symbol of Dutch heritage, 'a marble statue was unveiled in Museum Boymans in Rotterdam, and miniature copies of this bust were sold to the general public - the poet had now literally become everybody's property' (Jensen 2012). The replication and dissemination of the objects of national museums reassured the communities about the value of the originals they owned. A list of reproductions distributed at different levels and by different means and media across Europe would provide a good idea of the cosmopolitanism of the most famous museum pieces, which could map the extension and frontiers of the influence of each national museum. In art as well as scientific collections, the important task is to capture things 'less in as much as they crystallize the extent of work or energy and more in as much as they multiply it' (Daston 2004).

The museum as a place for the reproduction of images and objects has continuously had to deal with the market, but also to negotiate with the legal constraints and technical issues of reproduction. The different varieties of copyright throughout Europe had vexatious effects on copy regulations from country to country. As Katie Scott described it in France (Scott 1998; Deazley et al. 2010), the situations during the Enlightenment and at the end of the nineteenth century onwards were very different with regard to the representation of authenticity and of intellectual property. André Malraux's 'imaginary museum' in the 1960s was an interesting by-product of the photographic reproductions as well as the result of aesthetic speculation, just as the use of slides in art history classes took over from actually viewing work in the museum.

In the digital age, 'all ordinary uses of a creative work are regulated because all ordinary uses trigger copyright law - because any use is a copy. [ ... ] thus control is radically greater than the control of the law of copyright in an analogue world' (Lessig 2008). The defence of the 'real museum' by the curators goes sometimes so 
far as to absolutely forbid taking photographs inside the museum, as now in Orsay in Paris, in the name of the true love of art. On the contrary, the Tate (with the organization of Tate Encounters) has re-envisaged the visual composition of the art museum 'by premising visual media engagements within the Collection, primarily through digital photography and online remediation' (Dibosa 2008). Such operations even produced the aura of the original, according to sociologist Bruno Latour (Hennion and Latour 2003), who inverted the theory developed by Walter Benjamin about the loss of aura of the work of art in the age of technical reproducibility (Nelson 2000). In this perspective, the aura of the artwork seems to be more and more reinforced by the abundance of images taken from museums (McCauley 2008; Bayne et al. 2009).

\section{Conclusion}

National museums of art have been instrumental in giving to each European nation a precious image of its identity as well as of its ranking in the development of civilization. The achievements of each national school of painters and sculptors are supposedly linked to the physical, political and spiritual qualities of its country, according to the schema first initiated during the Enlightenment by the German antiquarian Winckelmann, the alleged inventor of modern history of art, even if he only wrote about ancient art. The vocation of a national museum for displaying great art is to offer a panorama of artists that illustrates and emulates the nationality of the different versions of European art - the Englishness of English art, the Frenchness of French art, and so on. The subjects and themes of the works of art displayed in any national museum are of course very diverse - and so are the styles and treatments of the different artists. Nevertheless, the national works of art could be defined in the museums by their subject matter - a specific iconography pronouncing a certain number of themes as 'national' - by their geographic origins or installations, or by the special fame of some artists in certain locations. Landscapes, portraitures, conversation pieces, political or religious allegories, courtly commissions or bourgeois interiors represented by the different schools at different moments were regularly considered by visitors as related to specific representations of time and place, of interests and mentalities, and as testimonies of the national communities (Smith 2013). Through these seemingly disparate and heteroclite collections it was possible to acquire a strong feeling of belonging to a collectivity by some resemblance of faces, of dress, of manners and habits, of cooking and celebrating, and by partaking of historical icons, common values and intimate feelings.

The importance of the flags of folklore and ethnicity or archaeology grew from the 1850s and led to the vicious debates that raged over the 'real' nationality of certain art galleries. This new sense of national identity applied to art developed beside the older antiquarian tradition, providing both an ethic and an aesthetic canon, according sometimes to a quasi-biologization of art related to primitivism (Gombrich 2002). Finally, in some totalitarian states of the twentieth century, the national art museum had to illustrate the peculiar style of a party that pretended to 
govern art as it ruled its propaganda. From these uses to the liberal protection of museums in welfare states, such as Alma S. Wittlin advocated it in the first book that can be labelled as 'museum study', published in the International Library of Sociology and Social Reconstruction of Karl Mannheim (Wittlin 1949), the historical situations have largely determined the face of these institutions.

It has been possible, during the two and a half centuries of its 'modern' history, to describe the European art museum as the nomos of the state, the instrument of academism, or, in contrast, as the proof of the autonomy of the art field with regard to the field of power. Several different factors may explain why one art museum has chosen this or that artist, this or that style or artistic movement, why it privileged international over national art, or conservative before avant-garde art, or the reverse. A number of considerations and motivations concur to the formation of a collection and of its spatial display, as well as to the building of various discourses and conversations concerning politics, taste, opportunism, the profile of the curator, organization, the context of the private collections and of the art market, artistic education and so on.

Since the 1990s the development of national art museums has been more or less directly conceived in an international context that goes largely beyond the national and even the European scale. This is especially true for the new museums of contemporary art that symbolize the synchronization of a country elite with international trends. Today art museums offer venues to express a wide range of materials, ideas and sensibilities, as they are involved in the art market, in cultural policies, in the agenda of governments, as well as in the idiosyncrasia of artists sometimes invited as temporary curators of exhibitions. The national art museums must now be sanctified by contemporary tourism and leisure-time activities, in a post-modern world where 'edutainment' rules most of the various global networks in the matters of art (Belting and Buddensieg 2009).

\section{References}

Adam, T. (2009) Buying Respectability. Philanthropy and Urban Society in Transnational Perspective, 1840 s to 1930 s, Bloomington: Indiana University Press.

Allie, T. (2010) 'Criminals and tourists: prison history and museum politics at the Bargello in Florence', Art History, 33(5): 836-55.

Amundsen, A.B. (2011a) 'National museums in Iceland', in P. Aronsson and G. Elgenius (eds.) Building National Museums in Europe 1750-2010, Eunamus Report No 1, Linköping: Linköping University Electronic Press, 425-34.

- (2011b) 'National museums in Norway', in P. Aronsson and G. Elgenius (eds.) Building National Museums in Europe 1750-2010, Eunamus Report No 1, Linköping: Linköping University Electronic Press, 325-434.

Appadurai, A. (ed.) (1996) Modernity at Large: Cultural Dimensions of Globalization, Minneapolis: University of Minnesota Press.

Arlaud, S. (2008) 'Les revues d'art viennoises de la fin de siècle ou comment construire une nation. Étude de cas: la Hohe Warte de Joseph August Lux', Germanica, 43: 183-92.

Aronsson, P. and Elgenius, G. (2011) (eds.) Building National Museums in Europe 1750-2010, Eunamus Report No 1, Linköping: Linköping University Electronic Press.

Ashmore, S. (2008) 'Owen Jones and the V\&A Collections', V\&A Online Journal, No. 1. 
Augusteijn, J. and Storm, E. (eds.) (2012) Region and State in Nineteenth-century Europe: Nation-building, Regional Identities and Separatism, London: Palgrave Macmillan.

Bailkin, J. (2004) The Culture of Property: The Crisis of Liberalism in Modern Britain, Chicago: University of Chicago Press.

Baker, M. and Richardson, B. (eds.) (1997) A Grand Design: The Art of the Victoria and Albert Museum, London: V\&A Publications.

Barringer, T.J. and Flynn, T. (eds.) (1998) Colonialism and the Object: Empire, Material Culture, and the Museum, London and New York: Routledge.

Bayne, S., Ross, J. and Williamson, Z. (2009) 'Objects, subjects, bits and bytes: learning from the digital collections of the national museums', Museum and Society, 7(2): 110-24.

Belting, H. (2000) The Germans and Their Art. A Difficult Heritage, New Haven and London: Yale University Press.

Belting, H. and Buddensieg, A. (eds.) (2009) The Global Art World: Audiences, Markets and Museums, Ostfildern: Hatje Cantz Verlag.

Bergvelt, E., Meijers, D.J., Tibbe, L. and Van Wezel, E. (eds.) (2009) Napoleon's Legacy: The Rise of National Museums in Europe, 1794-1830, Berlin: G+H.

_-(2011) Museale Spezialisierung und Nationalisierung ab 1830. Das Neue Museum in Berlin im internationalen Kontext, Berlin: $\mathrm{G}+\mathrm{H}$.

Bjurström, P. (1992) Nationalmuseum 1792-1992, Stockholm: Nationalmuseum.

Bourdieu, P. and Darbel, A. (1991) The Love of Art: European Art Museums and Their Public, Stanford: Stanford University Press.

Calder, B. (2009) "Never so serious": the Sainsbury wing of the National Gallery, London', Studies in the History of Art, 73: 183-99.

Candlin, F. (2008) 'Museums, modernity and the class politics of touching objects', in $\mathrm{H}$. Chatterjee (ed.) Touch in Museums: Policy and Practice in Object Handling, Oxford: Berg, 9-20.

Clark, T.J. (2006) The Sight of Death: An Experiment in Art Writing, New Haven, CT: Yale. University Press.

Colorado Castellary, A. (2008) Éxodo y exilio del arte. La odisea del Museo del Prado durante la Guerra Civil, Madrid: Cátedra.

Conlin, J. (2000) 'Le "Musée de marchandises": the origins of the Musée CognacqJay', Journal of the History of Collections, 12: 2193-202.

-(2006) The Nation's Mantelpiece: A History of the National Gallery, London: Pallas Athene. (2010) 'Philanthropy without borders: Calouste Gulbenkian's founding vision for the Gulbenkian Foundation', Análise social, 45(195): 277-306.

Crary, J. (1999) Suspensions of Perception: Attention, Spectacle and Modern Culture, Cambridge MA: MIT Press.

Cuno, J.B. (ed.) (2004) Whose Muse? Art Museums and the Public Trust, Princeton, NJ, and Oxford: Princeton University Press; Cambridge, MA: Harvard University Art Museums.

Daston, L. (2004) 'The glass flowers', in L. Daston (ed.) Things That Talk: Object Lessons from Art and Science, New York: Zone Books, 223-56.

Deazley, R., Kretschmer, M. and Bently, L. (eds.) (2010) Privilege and Property: Essays on the History of Copyright, Cambridge: Open Book Publishers.

Dibosa, D. (2008) 'Besides looking: patrimony, performativity and visual cultures', Tate Research, 3: 1-15, www2.tate.org.uk/tate-encounters/edition-3.

Digout, A.E. (2009) 'Renewal in the New Hermitage: the restoration of Leo von Klenze's Galleries in the State Hermitage Museum', St Andrews Journal of Art History and Museum Studies, 13: 69-79.

Dudley, S., Barnes, A.J., Binnie, J., Petrov, J. and Walklate, J. (eds.) (2012) Narrating Objects, Collecting Stories, London: Routledge.

Duncan, C. and Wallach, A. (1980) 'The Universal Survey Museum', Art History, 3(4): 448-69.

Duncan, S.A. (2002) 'From period rooms to public trust: the authority debate and art museum leadership in America', Curator: The Museum Journal, 45: 93-108.

Edwards, E., Gosden, C. and Phillips, R.B. (eds.) (2006) Sensible Objects: Colonialism, Museums and Material Culture, Oxford: Berg. 
Effros, B. (2008) 'Selling archaeology and anthropology: early medieval artefacts at the Expositions universelles and the Wiener Weltausstellung, 1867-1900', Early Medieval Europe, 16(1): 23-48.

Émeric-David, T.-B. (1796) Musée olympique de l'École vivante des beaux arts, ou Considérations sur la nécessité de cet établissement, et sur les moyens de le rendre aussi utile qu'il peut l'être. Mémoire Présenté à l'Institut National, Paris: Plassan.

Falser, M. (2011) 'Krishna and the plaster cast: translating the Cambodian temple of Angkor Wat in the French Colonial period', Transcultural Studies, 2: 6-50.

Fyfe, G. (2004) 'Reproductions, cultural capital and museums: aspects of the culture of copies', Museum and Society 2(1): 47-67.

Gaehtgens, T.W. (1992) Die Berliner Museumsinsel im Deutschen Kaiserreich: zur Kulturpolitik der Museen in der wilhelminischen Epoche, Munich: Deutscher Kunstverlag.

Gazi, A. (2011) 'National museums in Greece: history, ideology, narratives', in P. Aronsson and G. Elgenius (eds.) Building National Museums in Europe 1750-2010, Eunamus Report No 1, Linköping: Linköping University Electronic Press, 363-400.

Giebelhausen, M. (ed.) (2003) The Architecture of the Museum: Symbolic Structures, Urban Contexts, Manchester: Manchester University Press.

Gombrich, E.H. (1996) The Essential Gombrich: Selected Writings on Art and Culture, ed. R. Woodfield, London: Phaidon Press.

-(2002) The Preference for the Primitive: Episodes in the History of Western Taste and Art, London: Phaidon Press.

Greenblatt, S. (1991) 'Resonance and wonder', in I. Karp (ed.) Exhibiting Cultures: The Poetics and Politics of Museum Display, Washington, DC: Smithsonian Institution Press, 42-56.

Greenfield, J. (2007) The Return of Cultural Treasures, New York: Cambridge University Press.

Grewe, C. (2012) 'The writing on the wall', Museum History Journal, 5(2): 207-44.

Guadet, J. (1901) Éléments et théorie de l'architecture, Paris: Librairie de la Construction moderne.

Hall, S. (2001) 'Museums of modern art and the end of history', in S. Hall and S. Maharaj, Modernity and Difference, London: Institute of International Visual Arts, 8-23.

Haskell, F. (2000) The Ephemeral Museum: Old Master Paintings and the Rise of the Art Exhibition, New Haven: Yale University Press.

Hennion, A. and Latour, B. (2003) 'How to make mistakes on so many things at once - and become famous for it', in H.U. Gumbrecht and M. Marrinan (eds.) Mapping Benjamin: The Work of Art in the Digital Age, Stanford: Stanford University Press, 91-7.

Hill, K. (2005) Culture and Class in English Public Museums, 1850-1914, Burlington: Ashgate.

Holo, S. (1999) Beyond the Prado: Museums and Identity in Democratic Spain, Smithsonian Institute Press.

Jenkins, I. (1992) Archaeologists and Aesthetes in the Sculpture Galleries of the British Museum 1800-1939, London: The Trustees of the British Museum; British Museum Press.

Jensen, L. (2012) 'Commemorating Tollens: cultural nationalism, literary heritage, and Dutch national identity', Dutch Crossing, 36(3): 244-55.

Jevons, S. (1883) 'The use and abuse of museums', in Methods of Social Reform and Other Papers, London: Macmillan.

Kaufmann, T.D. (2004) Toward a Geography of Art, Chicago: University of Chicago Press.

Kesner, L. (2006) 'The role of cognitive competence in the art museum experience', Museum Management and Curatorship, 21(1): 4-19.

Klonk, C. (2009) Spaces of Experience: Art Gallery Interiors from 1800 to 2000, New Haven and London: Yale University Press.

Kristeller, P.O. (1951) 'The modern system of the arts', Journal of the History of Ideas, 12: 496-527 and 13: 17-46.

Kuutma, K. (2011) ' National museums in Estonia', in P. Aronsson and G. Elgenius (eds.) Building National Museums in Europe 1750-2010, Eunamus Report No 1, Linköping: Linköping University Electronic Press, 231-60. 
Kvaran, Ó and Kristjánsdóttir, K. (eds.) (2001) Confronting Nature: Icelandic Art of the 20th Century, Reykjavík: National Gallery of Iceland.

Lessig, L. (2008) Remix: Making Art and Commerce in The Hybrid Economy, London: Bloomsbury.

Loir, C. (2001) 'La politique muséale du jeune État belge. L'achat des collections artistiques de la Ville de Bruxelles', in G. Kurgan-van Hentenryk, and V. Montens (eds.) L'Argent des arts, Brussels: Éditions de l'Université de Bruxelles, 43-61.

Long, V. (2001) 'Les collectionneurs d'œuvres d'art et la donation au musée à la fin du XIXe siècle: l'exemple du musée du Louvre', Romantisme, 31(112): 45-54.

Lorente, J.P. (2011) The Museums of Contemporary Art: Notion and Development, Burlington: Ashgate.

Macleod, D.S. (1996) Art and the Victorian Middle Class: Money and the Making of Cultural Identity, Cambridge: Cambridge University Press.

Manojlović-Pintar, O. and Ignjatović, A. (2011) 'National museums in Serbia: a story of intertwined identities', in P. Aronsson and G. Elgenius (eds.) Building National Museums in Europe 1750-2010, Eunamus Report No 1, Linköping: Linköping University Electronic Press, 779-816.

Mazan, K. (2011) 'National museums in Poland', in P. Aronsson and G. Elgenius (eds.) Building National Museums in Europe 1750-2010, Eunamus Report No 1, Linköping: Linköping University Electronic Press, 667-88.

McBride, D.B. (2006) 'Modernism and the museum revisited', New German Critique, 99: 209-33.

McCauley, A. (2008) "Merely mechanical": on the origins of photographic copyright in France and Great Britain', Art History, 31: 157-78.

McIsaac, P.M. (2007) 'Public-private support of the arts and German cultural policy: the case of Wilhelm Bode', International Journal of Cultural Policy, 13(4): 371-91.

Meijers, D.J. (1995) Kunst als Natur. Die k.k.Gemäldegalerie in Wien um 1780, Milan and Vienna: Schriften des Kunsthistorischen Museums.

Nelson, R.S. (2000) "The slide lecture, or the work of art "history" in the age of mechanical reproduction', Critical Inquiry, 26(3): 414-34.

Paul, C. (ed.) (2012) The First Modern Museums of Art: The Birth of an Institution in 18th-and Early-19th-Century Europe, Los Angeles: Getty Publications.

Pergam, E.A. (2011) The Manchester Art Treasures Exhibition of 1857: Entrepreneurs, Connoisseurs and the Public, Burlington: Ashgate.

Petropoulos, J. (2000) The Faustian Bargain: The Art World in Nazi Germany, Oxford: Oxford University Press.

Pevsner, N. (1976) A History of Building Types, London: Thames \& Hudson.

Pointon, M.R. (1993) Hanging the Head: Portraiture and Social Formation in Eighteenth-Century England. New Haven: Yale University Press.

- (ed.) (1994) Art Apart: Art Institutions and Ideology Across England and North America, Tuscaloosa: University of Alabama Press.

Popović, V. (1991) 'Narodni muzej u Beogradu 1844-1944', in V. Popović and N. Jevremović, Narodni muzej u Beogradu 1844-1944, Belgrade: Narodni muzej, 7-34.

Portus Perez, J. (2009) 'La Sala de las Meninas en el Museo del Prado; o la puesta en escena de la obra maestra', Boletín del Museo del Prado, 27(45): 100-28.

Poulot, D. (1997) Musée, nation, patrimoine, 1789-1815. Paris: Gallimard.

- (ed.) (2012a) Goûts privés et enjeux publics dans la patrimonialisation XVIIIe-XXIe siècle, Paris: Publications de la Sorbonne.

- (2012b) Letters to Miranda and Canova on the Abduction of Antiquities from Rome and Athens, Los Angeles: Getty Research Institute.

Puloy, M.G. (1998) 'Hitler's Linz collection: acquisition, predation and restitution', Journal of History of Collections, 10(2): 207-24.

Rampley, M. (2010), 'Design reform in the Habsburg Empire: technology, aesthetics and ideology', Journal of Design History, 23(3): 247-64. 
Reisz, T. (2013) 'Facing the city', Artforum International, 51(7): 119-20.

Rindzeviciute, E. (2008) Constructing Soviet Cultural Policy: Cybernetics and Governance in Lithuania after World War II, dissertation, Jönköping University.

Rionnet, F. (1996) L'Atelier de moulage du musée du Louvre 1794-1928, Paris: Réunion des musées nationaux.

Roberts-Jones, F. (1987) Chronique d'un musée: Musées royaux des beaux-arts de Belgique, Bruxelles, Liège, Mardaga.

Rosenberg, H. (1994) The Tradition of the New, New York: Da Capo Press.

Roxburgh, D. (2013), 'Open Sesame!', Artforum International, 51(5): 61-2.

Schorske, C.E. (1980) Fin-de-Siècle Vienna: Politics and Culture, New York: Alfred A. Knopf.

Scott, K. (1998) 'Authorship, the academie, and the market in early modern France', Oxford Art Journal, 29-41.

Shaw, W. (2011) 'National museums in the Republic of Turkey: palimpsests within a centralized state', in P. Aronsson and G. Elgenius (eds.) Building National Museums in Europe 1750-2010, Eunamus Report No 1, Linköping: Linköping University Electronic Press, 925-52.

Shaya, G. (2004) 'The Flâneur, the Badaud and the making of a mass public in France circa 1860-1910', The American Historical Review, 109(1): 41-77.

Sheehan, J. (2000) Museums in the German Art World from the End of the Old Regime to the Rise of Modernism, Oxford: Oxford University Press.

Smith, A. (2013) “The land and its people": reflections on artistic identification in an age of nations and nationalism', Nations and nationalism 19(1): 87-106.

Stankiewicz, M.A. (1984) "The eye is a nobler organ": Ruskin and American art education', Journal of Aesthetic Education, 18(2): 51-64.

Storm, E. (2009) 'Painting regional identities: nationalism in the arts, France, Germany and Spain, 1890-1914', European History Quarterly, 39(4): 557-82.

-(2014) 'Overcoming methodological nationalism in nationalism studies: the impact of tourism on the construction and diffusion of national and regional identities', History Compass, 12(4): 361-73.

Tamen, M. (2009) Friends of Interpretable Objects, Cambridge, MA: Harvard University Press.

Taylor, B. (ed.) (1999) Art for the Nation: Exhibitions and the London Public, 1747-2001, Manchester: Manchester University Press.

Thiesse, A.M. (2012) The Transnational Creation of National Arts and Crafts in 19th-Century Europe, Antwerp: Nise.

Thomas, S. (2013) 'The spectre of empire in the British Art Museum', Museum History Journal, 6(1): 105-21.

Troilo, S. (2005) La patria e la memoria. Tutela e patrimonio culturale dell'Italia unita, Milan: Electa.

(2011) 'National museums in Italy: a matter of multifaceted identity', in P. Aronsson and G. Elgenius (eds.) Building National Museums in Europe 1750-2010, Eunamus Report No 1, Linköping: Linköping University Electronic Press, 461-96.

Van Santvoort, L., De Maeyer, J. and Verschaffel, T. (eds.) (2008) Sources of Regionalism in the Nineteenth Century: Architecture, Art, and Literature, Vol. 9, Leuven: Leuven University Press.

Verhoogt, R. (2007) Art in Reproduction: Nineteenth-Century Prints after Lawrence AlmaTadema, Jozef Israëls and Ary Scheffer, Amsterdam: Amsterdam University Press.

Vermeulen, I.R. (2010) Picturing Art History: The Rise of the Illustrated History of Art in the Eighteenth Century, Amsterdam: Amsterdam University Press.

Volait, M. (2009) Fous Du Caire: Excentriques, Architectes Et Amateurs D'art En Egypte 18631914, Paris: L'Archange Minotaure.

Waterfield, G. (2000) 'The origins of the early picture gallery catalogue in Europe, and its manifestation in Victorian Britain', in S. Pearce (eds.) Art in Museums, London: Continuum, 42-73. 
Watson, S. (2011) 'National museums in Scotland', in P. Aronsson and G. Elgenius (eds.) Building National Museums in Europe 1750-2010, Eunamus Report No 1, Linköping: Linköping University Electronic Press, 747-78.

Widen, P. (2011) 'National museums in Sweden: a history of denied empire and a neutral state', in P. Aronsson and G. Elgenius (eds.) Building National Museums in Europe 17502010, Eunamus Report No 1, Linköping: Linköping University Electronic Press, 881902.

Wittlin, A.S. (1949) The Museum: Its History and its Tasks in Education, London: Routledge \& Kegan Paul.

Wright, G. (ed.) (1996) The Formation of National Collections of Art and Archeology, Washington: The National Gallery of Art. 


\title{
5
}

\section{HISTORY MUSEUMS AND THE MAKING OF CITIZENS AND COMMUNITIES}

\author{
Ilaria Porciani
}

\section{History museums in times of presentism: theoretical considerations}

As a historian, my theoretical concern here is to understand how the narratives developed in museums interact with the overwhelming centrality of the present, the 'surfeit of memory' (Maier 1993), the growing presentism (Hartog 2002), the crisis of collective memory, and the sometimes conflicting memories of groups or even individuals (Frank and Rippl 2007).

As early as 1984, in the first volume of the Lieux de Mémoire, Pierre Nora pointed out the growing insecurity about a present and a future that seemed both fractured and uncontrollable. While society was taking the place of the nation and the tradition of memory was dissolving, the materialization of memory had tremendously dilated and multiplied, but had also become democratized and decentralized (Nora 1989). I am interested in understanding how museums react to the drastic change in the perception of time and how the regimes of historicity have produced the rapid growth of the overwhelming category of the present. In the 1980s, the shift from memory to history marked an epochal change, while heritage, a notion for times of crisis, was evoked in response to this general disorientation (Hartog 2002, 2013). Museums, and especially those dealing with history, are part of this process and subject to its problems.

Moreover, while historians have increasingly dealt with the present, the need to remember, recall and crystallize that same present has extended to individual memories, each of them partial and maybe blind to all but the group it binds. Those multiple voices of different witnesses, be they immigrants or survivors, colonized peoples, subaltern, minorities, natives or people once described as history-less because of their race, origins or social or gender inferiority, are now increasingly present in museums; their images and voices replicate our intensely retinal and powerfully televisual memory' (Nora 1989: 17). 
But does this plurality, probably better able to capture the complexity of the present, constitute the norm? Are the old models of museums glorifying the nation totally outdated? Recent cases seem to contradict this view. In Eastern Europe, new national history museums seek to fill the vacuum left by the collapse of communism through new narratives, and the nation has been identified as a powerful one (Berger and Lorenz 2008; Porciani and Raphael 2010; Porciani 2012). Poland and Croatia do not stand alone in this regard (Mazan 2011: 668); a similar path has been followed in cases of devolution such as Catalonia, Scotland and Wales (Mason 2011), or if a strong demand has emerged to negotiate more significant political autonomies, as is happening in the Basque country.

In this chapter, I argue that the growing presentism - sometimes explicitly recognized but probably more often unspoken - is the reason for the failure of a number of recent Western European proposals for national history museums. In Western Europe, while society museums seem to seek a multiple perspective, and while scholarship is deconstructing the national myths and the traditional linear master narratives, those museums that perpetuate the idea of a teleological blueprint seem to some extent anachronistic. As Hartog puts it, they seem to embody the 'simultaneous of the non-simultaneous' (Hartog 2002) by displaying histories that seemingly belong to another time if compared with the post-modern structure and narrative of society museums.

Secondly, I am interested in approaching the subject of history museums through the lens of Verfassungsgeschichte - a German term that well describes the study of both the formal constitution and the complexity of the overall balance of power relations. In fact, museums of history are part of the field of tension and the dialectic between knowledge (Wissenschaft) and state power, and they mirror both levels. Moreover, they reflect two further aspects: the current shift from the strong concept of government to the more fluid one of governance, which refers to a profound transformation of social and political relations, as well as to a shifting balance between public and private (Schiera 2013) and to the pact, the covenant or agreement that is at the core of the state.

Finally, I want to draw attention to the issue of borders. In the nineteenthcentury museums and their epigones, borders were firmly fixed in the cartographic imagination rooted in the powerful nation-state and its imperial ambitions. Those borders also reflected the strong complex of discipline and power that is well summarized in the German notion of Disziplinierung (Schiera 2013). However, they have now become more porous and crisscrossed: 'far from serving merely to block or obstruct global passages of people, money or objects, [they] have become central devices for their articulation' (Mezzadra and Neilson 2013: ix). History museums face not only the modification of temporality regimes but also these changes. Museums often present borders as still sharply demarcated. Yet, individual life stories could highlight not only the traditions of the different ethnic groups but also the crisscrossing of many individuals and the dimension of borders as more fluid. In 2013 Mezzadra and Neilson argued that borders should be approached as an 'epistemic' perspective rather than a distinct 
object of study and suggested focusing on subjects not essentialized in their identities but seen 'in motion'.

Similar suggestions have also been made by innovative works on museums that propose that collections (especially colonial ones) should go beyond dichotomy and tell the story of the crossing of borders by people and objects, ethnic groups, settlers and immigrants, intellectuals and artists, cultural models and anthropological habits. Objects can sometimes highlight the complexity of travel and encounter by going beyond a simplistic approach focused only on relations of exploitation and conquest (Pratt 1992; Witcomb 2004). Through objects it is possible to shed light on the special and temporal co-presence of subjects previously separated but whose trajectories now intersect. Artefacts going back and forth from the West to the colonies linked people across generations and across boundaries. Museums have always contained materials of interwoven histories, but only recently have they started to present these interwoven histories in a new way, drawing attention to the formation of the collections and to the different ways in which they can be used to represent contacts and links, and to explore often complicated ties extending beyond dual, static relationships. In short: it is the exchange that should be discussed, studied and displayed (Henare 2005) within museums as contact zones (Clifford 1997).

Moreover, these museums aim to write the autobiography of the nation. Here the concept of pact, already mentioned with reference to the constitution, recurs in a wider metaphorical sense. A history museum, all the more so if it deals with the challenges of the present, does not only mirror the constitutional pact and its possible shortcomings. It is also an expression of the pacte autobiographique studied and defined by Philippe Lejeune. He argued that the author of an autobiography makes an agreement with the reader to show himself as he is, even if this implies highlighting his difficulties, shortcomings, faults and contradictions (Lejeune 1975). However, highlighting them in an autobiography is probably less difficult than doing so in a museum.

Faced with the new challenges of immigration, and mirroring the difficulties of devolution as well as other constitutional problems and the controversial issue of the extension of citizenship, museums dealing with history - and increasingly also with the history of the present - have a difficult task. I argue that they will be able to perform their role only in a plural dimension, and in one of transformation. As the lieux de mémoire studied by Nora have done, they will have to display all their capacity for metamorphosis, recycle their meaning, and come to terms with the unpredictable proliferation of their ramifications. In short, they will have to become similar to the first nations' transformation masks on display in Canadian museums of civilization. These masks open up like Chinese boxes to show various totemic animals, thus encompassing plurality and transformation but also renouncing the norm of uniqueness. Still, history museums will also have to represent relationships and interconnections among different groups and histories.

In the past three decades, history museums have undergone rapid and profound changes. As the Eunamus reports show very well (Aronsson and Elgenius 2011), they have grown in number. Moreover, their multifaceted activity at the crossroads of research and the production of master narratives and public history have expanded, 
while their typology has also changed, to some extent incorporating the model of society museums in order to respond to the needs of citizens and communities.

Scholarship on this subject has also experienced a 'tidal wave' (Starn 2005) and has engaged in intense discussion with sociology, anthropology, ethnography and cultural studies. Historians have also started to research the subject, so that the label 'museum studies' appears reductive for the majority of the most recent publications. With reason, Luca Basso Peressut has highlighted the national, transnational, and multicultural perspectives of this large body of research, which variously focuses on museums' social commitments and narratives, their new spaces, and their attempts to represent increasingly multiple perspectives. Moreover, on considering literature from France, Italy and the Spanish-speaking countries, Basso Peressut has depicted a richer panorama than the one reflected by English or American literature (Basso Peressut and Pozzi 2012). In short, disciplinary borders seem to blur not only in the museums, which are the subject of this chapter, but also within scholarship.

This chapter explores the changing role of history museums in Europe by adopting a comparative approach focused on some European countries. However, since museums have increasingly become global and transnational, and likewise their models and languages, it is impossible to deal with the European picture without considering the suggestions proposed, but also the problems raised, where postcolonial perspectives have been defined earlier. Thus I will first briefly recall the case of the Museum of the American Indian and discuss the complexity and contradictions of the Canadian case. Secondly, I will outline some European cases in which an older Blut und Boden perspective - so crucial to the construction of the imagined community of the nation - has recently emerged, and I will discuss this perspective from a different standpoint. The role of the soil in history museums - I argue should be deconstructed and presented in a different and more historical light. Gender should also be deconstructed and used as a useful approach to the history of a country, rather than to confirm ethnic myths. I will then concentrate on some countries (the Netherlands, France, Spain, but also Austria and, more in detail, Italy) where projects for national history museums, charged with old-fashioned nationalistic proposals, overlap with memory wars, debates on memory politics, and the drafting of the canons of national history, often fuelled by jubilees - as usually happens and has done so even more frequently in recent decades (Johnston 1991; Cauvin 2011).

As for chronology, 1989 is an obvious watershed for Europe. Yet, a periodization starting with the 1980s makes it possible, on the one hand, to consider the growing patrimonialization (Guillaume 1980) and the birth of a wave of museums dealing with societies and social history (Fleming et al. 1993; Chevallier 2013) or with first nations, or immigration (Vanderlink 2011) while, on the other, it encompasses the important work on the lieux de mémoire (Nora 1982-94).

\section{Outside Europe: giving voice to the subaltern and the colonized}

Museums have been features and strategies of colonization in two ways: the colonizers incorporated the treasures, and to some extent the bodies, of the natives of the 
countries discovered and conquered, and organized in those countries museums to discipline and teach. Thus the Western gaze was overwhelming and the direction went from Europe to the 'margins' (Anderson 1991). This trend has been recently reversed, so that it starts from those countries where the claims to give voice to the first nations and the aboriginals have been stronger and more urgent. In many cases, minority groups and lobbies have made large use of museums. Those groups, whether technically speaking disenfranchised or not, have pressed for their active presence in museum policies and for a strong symbolic representation mirroring their negotiation for rights, recognition, and in some cases compensation, as well as for a more active role in society. Here, the ambiguities and the twofold meaning of the word 'representation' (to put on display or to represent) are both present.

Moreover, both Verfassung and formal constitution are at stake when discussing the Australian, but also the Canadian, museums: these issues have figured prominently on those museums' agendas, as well as in constitutional changes and debates. Museums have mirrored the contradictions of the 1975 Australian Racial Discrimination Act, and they have intertwined with the campaign for the recognition of the Aboriginal and Torres State Island people by the Australian federal constitution. Museums have reflected the recognition of natives by the constitutions of the states of Victoria (2007), New South Wales and Queensland (2010), but they have also played a role in that recognition. Altogether, in Australia they have been at the centre of a policy of recognition (Bennett et al. 1996; Boswell and Evans 1999; Simpson 1996; Kirwan 2011).

In the United States, the National Museum of the American Indian, opened in Washington in 2004 (Pagani 2013), adopted an identity-based paradigm in terms of a cultural policy based on the concept of a largely constructed 'Indian voice'. The 'living museum' and the policy of 'stewardship' focus on the present and future of the natives and stress the 'survivance' of their culture. A bias towards essentialism seems to shine through. However, this essentialism is to some extent implicit in the specific juridical dimension of the rights of indigenous people, in the legal recognition of the first nations, and in the treaties that recognize the first nations as such, as well as in the role of the National Congress of American Indians in the United States, or of the Assembly of First Nations in Canada. Once again, the common law dimension and the Verfassung should be borne in mind.

The case of Canada is interesting because it presents a complex picture that cannot be reduced to the simple dichotomy between colonizer and colonized. It is also interesting because it was at the centre of debate and the far-reaching consultation on the future of one of Canada's main museums. The Canadian museums mirror the coexistence and the conflict between the British and the French settlers, the strong demand for recognition by the first nations, but also by other groups such as the black Canadians descended from slaves, or immigrants from Asia and various European countries. Museums have been at the core of the implementation of the official policy of multiculturalism first announced by Pierre Trudeau and formalized through the Act for the Preservation and Enhancement of Multiculturalism in Canada (1988). 
[They] have been picketed, boycotted, and criticized for perpetuating colonial ideologies and oppressive policies; they have been called upon by governments to implement official multicultural policies; and some have also chosen to play proactive roles by advocating more radical forms of social intervention and reform.' In short, the challenge raised by aboriginal activism against the traditional construct of Canada as a settler nation rooted in colonial histories provided not just the backdrop to a history of museum change but was also its enabling condition. Thus from traditional bastions of high culture, museums became 'sites for wide social and political transformation.

(Phillips 2011: 8)

Transnational effects were also apparent after the international boycott of The Spirits Sing exhibition (1992), which involved the formation of a task force on museums and first peoples. Curators in the US and Britain learned from these experiences and controversies and understood the need to expand the consultation process.

Museums have been at the core of the increased demand by indigenous people around the world for protection, repatriation, and control of cultural heritage in accordance with their laws and protocols, internal structures, and priorities' (Bell and Napoleon 2008). A detailed definition of constitutional rights is involved; consider the 1982 Constitution Act (35/1) recognizing the treaty rights of the Aboriginal people of Canada, which is deeply involved with the issue of repatriation as an act of claiming metaphorical territory via the control of an object. Thus museums are symbols of land ownership.

In all these cases the borders have been fairly strong and clear-cut: in the case of the Museum of the American Indians, they do not replicate the national borders but mark out the larger space of the American continent, in order to map the Indian nation also in Canada and even in Argentina. Thus, the border between 'us' (the Indians) and 'the others' (this time the settlers) is firmly drawn. The perspective is reversed, but it nevertheless remains unilateral, to some extent essentialist (Murphy 2007) and thus not unproblematic.

The Canadian Museum of Civilizations in Ottawa has until now presented a strong dichotomy based on a rigid separation between the settlers' civilization, displayed on the first floor, and the collections of artefacts made by the natives, displayed on the ground floor. However, this museum is now undergoing a process of profound change, which has involved the consultation of around 20,000 Canadians:

[S]cholars, students, writers and history buffs; museum professionals of all sorts; children, teachers, parents and family groups; community organizers, civic artists and ordinary citizens. They shared a country, a concern for its history and a general conviction that past stories, told well, were essential to their future. We listened, asked and answered questions, and took notes. We have now begun using these perspectives in planning our new history hall and programs. We dismissed no view, disrespected no opinion and rejected no help. 
It is not clear how this process will end and what the results will be. What is certain is that wide consultation - a sort of symbolic referendum - has taken place, and that it has at least had the positive effects of involving a large share of the population without provoking the sharp criticism that characterized the French debate. The extent to which the new museum will consider borders as porous, criss-crossed areas and will highlight contacts and relations is not yet clear.

As things now stand, in some cases the perspective may have been reversed, in the sense that voice has been given to those who previously had none. But identities have probably been emphasized, and they may have been essentialized, even if multiplied. In sum, borders have become sharper in museums. The Chinese immigrants and coolies so crucial for the construction of the Transpacific Railway are absent in the capital city's comprehensive museum and are to be found only in a separate museum in Calgary set up by their community. Black Canadians are certainly absent as well; in fact, they openly complained when even the Next Stop Freedom Exhibition ignored them (Ashley 2011). In order to hear the voices of other, more recent immigrants such as Poles, Italians or Greeks, one must visit the museum of the Pointe à Callière in Montreal. But even there, they appear in the form of videos that recount a series of individual life stories focusing on the specificity of each ethnic group and material culture. Moreover, the memory of the individual seems to overwhelm the memory of the group. Separation and sharp borders seem to be in many ways an important part of the picture. The model is that of pillarization: a 'pillar model of cultural heritage where communities are set apart without communication' (Lleras 2011: 460), but also where different life stories stand next to each other and do not seem to interact enough. Fragmentation apparently reigns. The necessity of representing so many voices often ends in the collection of multiple individual stories, where history is lacking and individual memories - plural and fragmented - dominate, and that confirm the overwhelming power of a fractured present.

\section{Blut, Boden and gender}

In Europe some recently created history museums have reproduced very oldfashioned patterns. In the museum of the history of Catalonia, as well as the National Museum of Scotland in Edinburgh, the story begins with rocks and skulls: a soil charged with strong ethnic feelings suited to representing the blood of a population which has always been there. No different is the approach of the Tyrol Panorama museum in Innsbruck, which was opened in 2011, where the Riesenrundgemälde, a wide circular painting, promotes a strong Tyrolean identity against a European one, as well as a sort of ethno-nationalism, once again based both on war and resistance and on 'nature'. Thus the 'Boden' comes together with the 'Blut' to stress the specificity of Tyrol and the attachment to its tradition. The rocks and the Alpine valleys are integral parts of this discourse, in the same way as the soil in Wroclaw's Panorama.

This pattern echoes that of major national museums of the nineteenth century. As we know, nature and landscape - which only a superficial gaze can consider 
neutral - have prominent roles in the Prague Museum or in the frescoes of the former entrance room of the Neues Museum in Berlin. But also new and very new museums develop along the same lines. In the new Hong Kong Museum 'the rocks tell a story': they are 'pages in Hong Kong history' (Stoke-Rees 2011: 343). They have been put on display in order to define the nation and its long-standing existence - an existence as long as 'geological eras'. Fortunately, the new Swiss National Museum is far from giving those affirmative answers and states that no one has been there from the beginning (Meyer 2013).

In several cases, the landscape has constituted a strongly distinctive feature of memory and national identity, as clearly shown by Nora's Lieux de Mémoire in regard to rural 'douce France'. The landscape has also been one of the essential elements of the literary canon in many countries, and perhaps in all of them. It has played a central role in poetry, novels, and songs. Generations of Italian students have learned a famous passage from Alessandro Manzoni's national novel, The Betrothed. The moment of leaving the native land behind is marked by a melancholy gaze that surveys the features of the well-known landscape. The synecdoche is obvious: the landscape narrated is the Italian one. The boundaries of Italy marked by the Alps and including Trentino, if not Istria as well, created a geographical topos of great usefulness also for irredentism and nationalism. The same applies to France: Bruno's Tour de France par deux enfants also significantly included the lost Alsace. The nation's 'landscape' is a powerful theme also reflected in the landscape paintings that constitute the core of so many national collections (Poulot 2012b). The Alps of Switzerland or the Rhine of Germany frequently form the background to the female allegories of the nation.

Nature has also functioned as a powerful construct in Japan, where it was used to celebrate a mythical 'uniquely harmonious, natural nationhood' (Adeney Thomas 2001: 2). Museums have been created as instruments and mirrors of the power of the nation to confirm its ethnic as well as its geographic borders. The natural history, historia naturalis, was subsumed under the historia magistra (of the nation). Is it not necessary to deconstruct this nineteenth-century myth and critically rethink the landscape not as Boden but as an increasingly fragile environment? One should introduce the themes of nature and environment (Hicks 2001) into national and also history museums, going beyond the concept of intangible heritage or the symbolic role of the landscape in the construction of the nation. The transformation of nature by the nation-states has been one of the key components of their policies both 'at home' and in the colonies. The impact of industrialization, and most recently of deindustrialization, on the landscape has been equally decisive. It seems necessary to consider the history of the nation-states from this point of view as well. Thus the rocks and the soil, the rivers and the mountains will identify not political frontiers to defend with weapons but another frontier to be addressed with the responsible tools of science. In short, no longer the Boden but the environment may become a crucial aspect of profound reflection on the country's history, which concerns all those who live in it. Rethinking environmental politics in history museums might perhaps give rise to a less blind and more 'constructive' patriotism. 
Deconstruction should probably be applied also to the gender representation of the nation that has so strongly moulded the old national history museums. There, the strongly dichotomized representation of male/female roles has been dominant, but gender has not yet been utilized as an analytical category with which to understand the limits and features of the national imagination. Women have often been used in history or ethnology museums and exhibitions to embody the family of the nation and the reassuring force of the civilized 'us' as opposed to the savage or alien 'other'. In allegories, or simply through their costumes, women have represented the nation (Blom et al. 2000; Porciani 2008) in peace, in colonial politics, and even in war. And how often have the images of women's bodies injured, indeed raped, been present in museums dealing with the history of the nation like the 'barbarism' museum in Cyprus (Bounia and Stylianou-Lambert 2003)?

\section{From grand debates to national history museums: the Netherlands, France, Spain, Belgium and Austria}

In recent years, broad debates on the sense of national history have intertwined with proposals - often failed - to create national history museums. The actors are sometimes professional historians, but more often they are government agencies intent on creating or recreating a national canon often based on nineteenthcentury models of historicity and conflicting with the presentist regime and the lack of historical memory (and perhaps a sense of the future) among citizens. The space is, on the one hand, that of the historical discipline; on the other, it is the broader field of public history and the public use (and sometimes misuse) of history. Museums are at the crossroads of these issues and fields.

It is now time to discuss some European cases, starting with the Dutch and French ones, but also briefly considering Spain, Austria and Belgium, and, in a separate section, Italy.

The proposal for a Dutch National History Museum arose in the early 1990s due to two factors. On the one hand, the rebuilding of the Rijksmuseum risked reducing its department of national history (Van Hasselt 2011); on the other, a general lack of knowledge about Dutch history was identified. Mounting criticism of multiculturalism, the murders of Pym Fortuin and Theo Van Gogh, and the intention to increase integration speeded up the idea of constructing a canon of Dutch history as a cornerstone for a common identity. A new national history museum seemed the right institution with which to reinforce that canon by acting as a 'watchtower'. MPs Marijnissen and Verhagen were clear about the main issue:

A people without history does not exist. Every people, including the Dutch, have a history [ ... ] A National Historical Museum that coherently exhibits our history does not exist. The historical consciousness in our modern society will disappear if we do not change this [ ... ]. Due to the internet and globalisation, but also through individualisation of society and the arrival of 
more people with different cultural backgrounds, it seems we do not share a common identity any longer. ${ }^{1}$

In 2008, disagreement on the national canon resurfaced. A group of young historians worried by the narrowing of the concept of national identity proposed a counter-concept of the museum, while, on the other side of the barricade, even some MPs considered the 'canon' unsatisfactory. Probably because of the heated debate that took place also in the press, the CEO of the museum presented it - at least at first sight - as flexible and open, prudently distant from being monolithic. However, this did not make the issue any less contentious, as the recent failure of the project has proved.

France provided an even more controversial example when the community of historians reacted vehemently to President Sarkozy's proposal to create a 'house for French history' and to build a canon which seemed too narrow, outmoded, and still based on the model of 'our ancestors the Gauls' - a model entirely unable to match the growing complexity of French society.

The case of the Maison de l'Histoire de France, however, must be read against the background of another 'affaire'. This very French word seems extremely appropriate for the Grand débat sur l'identité nationale, which came into being at almost the same time. It was launched in November 2010 by the minister of immigration, integration, national identity and co-development 'to foster a more shared vision of what the national identity is today, and to reaffirm republican values and pride in being French'. Structured in pyramidal form, traversing all the departments and the 345 arrondissements, this debate was to have involved deputies and movements, associations, schools, citizens, and to be made virtually open to everybody by means of a website. However, the website has been closed, and the ministry has been abolished, dragged down by the collapse of the grand débat.

The criticisms were in fact very numerous. Suffice it to quote here the words of the former Prime Minister Rocard widely reported in the press 'This debate is completely idiotic [ ... ]. Nobody could feel more French than I do, and I am hopelessly proud of having been born in this country. But I do not want this opportunity to close out others in the name of a sectarianism extraneous to our history'. Among others, also Michel Le Bris, founder of the important literary festival Étonnants Voyageurs, now in its twenty-first edition, commented on several occasions that the concept of a unique identity is absurd in the contemporary age, since we are the result of a multiplicity of identities. Needless to say, as early as 1998 a report had pointed out the problem of the absence in French history museums of the various ethnic communities living in the country. This absence was matched by the lack of social and working-class history, or indeed economic history (Joly and Compère-Morel 1998: 69), a choice dictated by the ideology of assimilation. In the first decade of the twenty-first century, these absences were largely regarded as just as serious as those relative to the resounding silence on colonization and the Algerian War at the core of the memory wars. In spite of such warnings, the first Lemoine report was characterized by rigidity and identitarian 
essentialism, to which historians such as Christophe Charle and Daniel Roche reacted harshly, also in Le Monde. More flexible perspectives soon emerged as the result of mediations and negotiations. A broader group of historians was involved, and it fostered a more complex and open approach. However, this was not enough, and the project was de facto abandoned. The laconic conclusion of the French Wikipedia entry is telling: 'In August 2012 Minister of Culture Aurélie Filippetti announced that the project had been dropped because of François Hollande's engagements presented in the program for the presidential election campaign of 2012.'

This story should be read in parallel with recent attempts to deal with immigration in museums, often in separate spaces, as in the case of the French Cite Nationale de l'Immigration (Cohen 2007; Poulot 2012a). This opened in the Palais de la Porte Dorée laden with memories of Paris colonial exhibitions and tried to address the issue of immigration. Still, it was considered to be caught between a museification of immigration and a sort of auto-exotization that risked imprisoning the immigrant in a communitarian dimension (Gruson 2011).

In Spain, a proposal for a new museum has been linked with the debate on history in progress since the 1990s among diverse social and institutional actors, including political parties, regional governments, the Catholic Church and the armed forces, so that the concept of 'historical memory' (memoria histórica) has moved to the forefront of the public debate. At the origins of this movement in post-dictatorship Spain was a grassroots initiative in various parts of the country to unearth the mass graves and give proper burials to the victims of Francoist repression. This gained the support of large sectors of the Socialist Party, at first in opposition (1996-2004) and from 2004 to 2011 in government. In 2007, three years after the Socialist Party's electoral victory, the Parliament passed the Historical Memory Act (Ley de Memoria Histórica), which required the removal of symbols of the country's division and supported initiatives to open historical records and the mass graves of the repression's victims. Meanwhile, in the last years of John Paul II, the Vatican reactivated its policy (frozen for several decades) to beatify victims of anticlerical repression on the Republican side during the Civil War (Lanzarote Guiral 2012). This renewed interest in coming to terms with the recent past has led, among many other initiatives, to the restoration and opening to the public of the Civil War trenches on the Aragon Front, or the creation of the Refugio Museo de la Guerra Civil in Cartagena (Murcia). These initiatives, undertaken by regional governments or municipalities, have not yet received support from the state authorities in the form of a national museum of history. Nevertheless, a recent project to renovate an old national museum, the Museum of the Spanish Army (Museo del Ejército Español) has become entangled in the debate on the 'historical memory', as has the attempt to move part of the documents of the civil war from the Salamanca Archives.

In Austria, debates on the country's role after the Anschluss in the persecution of Jews - for long hidden - has characterized the memory wars and the end of long amnesias. The first proposal of a new Austrian national paradigm and a museum of 
national history (with the well-known exception of the military museum in Vienna) was put forward by president Karl Renner (Hanisch 2009; La Mattina 2013) in order to link the new republic created after World War II to the first Austrian Republic. In this case, Renner was celebrating his own role in the political life of the first Austrian Republic, having served as state chancellor in 1918-19 (Auer 1983: 79; Bentz and Raffler 2011). But the real point was that the controversial issue of Austrian responsibility under Nazism was silenced until the Waldheim affair (1986-8), which lifted the taboo on discussion of Austrian involvement in Nazi crimes. Problems with the recent past often induce a search for the origins of the nation in a more remote one. In 1996, the celebration of the Ostarrichi Urkunde allegedly testified to the medieval roots of Austrian identity (Bruckmüller 1994, 1995). Such short circuits and the strong need to emphasize the antiquity of the nation and to connect it with a remote golden age are not unique to Austria (Flacke 1998; Berger and Lorenz 2008; Evans and Marchal 2010). The Eunamus reports have presented similar examples more specifically related to museums. In Bulgaria, the intention was to highlight the 1,300th anniversary of the creation of a Bulgarian state - invented, needless to say, for a country that became independent in 1879 (Vukov 2011) - thus presenting the long Ottoman domination as a kind of parenthesis. In Bosnia Herzegovina, the process began in 1993, and therefore still during the war, when a national history museum was created with the aim of expanding the chronological time frame so as to include the arrival of the Slavs in the country.

In the Austria of 1999, in a climate also marked by the controversial political success and racist positions of Jörg Haider, the Nationalrat launched a competition for a Museum of Tolerance (or of History). But the suggestions expected from intellectuals and society did not materialize. Two opposite projects emerged, each backed by a different ministry, which focused on tolerance and on Austrian history, respectively. Neither of them was ever begun. In 2005, after the exhibition related to the 50th anniversary of the treaty that re-established Austria as an independent state, a team was created to prepare a new draft for a museum focusing on Republican Austria. Following further disputes, as happened in France, the team had to be enlarged, while historians took part in the discussion not only in the daily press but also in their scholarly journals, such as the Österreichische Zeitschrift für Geschichtswissenschaft. Unlike in France, however, the project was not withdrawn. In 2006 the road map was presented and the museum is expected to open in 2018 (Bentz and Raffler 2011).

In Belgium, it was the 175th jubilee of independence that provided the opportunity to open a history museum in 2005. The Bellevue palace in central Brussels, which hosted the museum of the dynasty founded in 1956, provided the location, and the funds of the King Baudouin Foundation helped solve the practical problems. The permanent exhibition titled BELvue still focuses on the prominent role of the dynasty, but it significantly enlarges the scope of the previous collection (Tollebeek 2010: 140). It seeks to present a large fresco of the Belgian state and society. It certainly downplays elements of conflict, and not by chance devotes 
large space both to the country's birth and constitution and to the growth of Brussels arts and crafts in the Belle Époque. Because the BELvue museum is intended for a large audience, it does not stand out as original and innovative, but it follows a quite traditional model. Moreover, it does not discuss the tensions between the Flemish and French populations, nor does it deal with the system of pillarization. However, it must be given credit for correcting the ethnocentric approach that had characterized the temporary exhibition held in the jubilee year, and for introducing a (still timid) reflection on the colonies. A more substantial revision is awaited from the ongoing renovation of the Royal Museum of Central Africa in Tervuren.

\section{Italy 2011: one proposal and two exhibitions in the difficult year of the 150th jubilee of the nation-state}

The Italian proposal for a comprehensive museum of the history of the country largely ignored by international scholarship and absent from the Eunamus report because it was still in the project stage - deserves more detailed considerations and a specific section. It is embedded in celebrations of the 150th anniversary of the Italian nation-state, initially prepared in the midst of uncertainties (Soldani 2011; Baioni 2012). The institutions and the ruling political parties - especially the Lega, constantly opposed to Rome and pursuing the strong devolution if not independence of so-called Padania - as declared in the party's statute - were not interested in celebrating the unification. Thus the celebrations were essentially supported by the President of the Republic Giorgio Napolitano (Levra 2011; Tosatti 2013: 66).

Contrary to the boom years of Italia 1961, the anniversary took place in a context of economic recession marked by drastic cuts to culture expenditure. The statements by the minister of the economy and finance that 'You cannot live on culture' and 'You cannot eat culture' further heightened the disquiet. Surprisingly, given these premises, the celebrations enjoyed great success. Amid Italy's deep political and moral crisis, exacerbated by the scandals surrounding the then Prime Minister Berlusconi, participating in the celebrations and even visiting history exhibitions and museums equated to demonstrating loyalty to institutions threatened by political scandal, and reaffirming the value of those institutions, or at least of the nation-state, and of a shared history. Thus, history museums and exhibitions enjoyed an unexpected success.

Moving away from the short time periods of the political events and focusing on the original features of Italian identity, it is useful to recall that scholars and commentators have highlighted the following: the constant tendency of Italians to split on political issues; the wide cleavage between state and civic society that dates back to the Church-state divide of the unification years; a weak civic sense (Gentile 2001); and the feeble foundations of 'italianità' (Patriarca 2013). Historians have in turn pointed out a dramatic loss of collective memory and of historical strongholds, a diminishing sense of belonging to a common res publica, as well as profound distortions affecting democracy as both a practice and a concept. 
Along with the political context and the reflections of historians, it is important to point out a third level: that of the public use of national history. Already some years before 2011, the historical problem of the elite or popular character of the Risorgimento and of the tensions between Church and state were mirrored and largely misused in the public arena. Some reactionary Catholics revived the 'black legend' of the Risorgimento. They first emphasized and exaggerated the 'myriad' of insurrections against the so-called Jacobin Republics of 1796-9, and then the resistance raised against the unification process in Southern Italy in the early 1860s, the so called brigantaggio. According to these authors, the French revolution had imported a secular model allegedly totally extraneous to Italy. In order to 'demystify' the lies and omissions of a supposedly 'Masonic' mainstream historiography, they argued that the only true Italian national experience - involving all social classes and not being only a top-down process - has always been Catholic. They therefore contended that opposition to the Risorgimento had been much larger than admitted by scholars, and that the annexation of the south had only brought problems: neither Garibaldi nor the feats of the Thousand were matters for celebration. Last but not least, Mazzini was labelled a totalitarian (Porciani 2012). Both the Lega and the right-wing Catholics proposed a history of Italy in which a native Italian character, on the one hand ethnic and on the other religious, has predominated.

The Catholic Church distanced itself from these extreme positions. Paradoxically, the anniversary of the conquest of Rome by the Piedmontese was chosen by the Vatican to declare that the Church had largely contributed to the Risorgimento, in spite of the fact that Pius IX very soon withdrew his support for the national movement and did not recognize the new Italian state.

It was in this climate of great strife, therefore, that an appeal for a new museum of Italy's history was launched by historian and commentator Ernesto Galli della Loggia and ancient historian Andrea Carandini. They argued that the Italians were willing to rediscover Italy because previous reference points had dwindled, owing to a 'covert sense of humiliation at the loss of prestige and image that we have long suffered and which induces us to react in the name of a re-found collective identity; perhaps also, finally, owing to growing awareness of the dreadful decay of Italy's cities and landscapes'. In short, Italians lack 'knowledge and awareness of the community in which we live'. Carandini and Galli della Loggia argued that there was no single specific place where an ordinary Italian could rapidly gain 'a visual and emotional experience of the extraordinary multiplicity of Italy's forms of historical, artistic, and cultural life'. The time had come to 'consider creating a great museum devoted to our history: the Museum of Italy's History.' 'Who could ever feel politically or ideologically offended by such a proposal?' asked the two scholars.

Who could take umbrage at a place where, alongside a codex of the Divine Comedy and a collection of votive offerings there appeared the interior of a Venetian jail; where together with Galileo's telescope one saw a Sicilian sulphur spring; where the inside of a Milanese drawing-room of the Age of the Enlightenment appeared next to the barrow of a Neapolitan water-seller, 
or reconstructions of the battles of the Piave and Caporetto; where it is understood what emigration meant for millions of Italians [ ... ] where the interior of the first radio broadcasting studio is exhibited together with a De Chirico painting of a piazza, or the plan of a Roman municipium, the model for numerous towns in the peninsula?

(Carandini and Galli della Loggia 2011)

Interestingly, the museum's proponents avoided using the term 'national' in its title, preferring the more neutral expression 'Italy's history' (Carandini and Galli della Loggia 2011).

Yet it was not easy to imagine from when this history should begin: with the national state, as argued by Benedetto Croce, or with the Middle Ages, as the scholars of the mid-nineteenth century suggested (Moretti and Porciani 2011)? With the Romans or with the ancient Italic people that left their mark on the dialects that arose from mediaeval Latin? And to what extent can one conceive of a geographical area that is entirely Italian? Should account not also be taken of how the history of the peninsula has interwoven with that of the world in terms of trade and cultural exchange, political interactions in the Mediterranean and European spheres, and in that of old and new globalization? Moreover, the long and heterogeneous list of suggestions seemed to look back at traditional canons (thus showing similarities with both the French and the Dutch proposals) while it did not consider really crucial issues such as the new problems of inclusion raised by recent immigration into Italy and self-reflection on long-standing divides. Moreover, it was difficult to imagine a single place in which all these exhibits could be assembled: in short, a single museum, which would indeed be complicated to create for such a composite and multilayered country as Italy. A few voices positively, albeit cautiously, took up the proposal made by both parts of a fragmented but nevertheless highly polarized political alignment. The most significant of them was that of the Catholic historian Alberto Melloni (2011), who cast doubt on the idea of one single museum because this might give rise to an assertive master narrative typical of the 'exhibitionary complexes' (Bennett 1988). Melloni instead emphasized the need to construct a network of museums, starting with those that already existed. Would it not be more interesting to work more decisively towards the model of the museo diffuso, which originated in Italy, and for good reason?

The proposal of the new museum came to naught. Mention should therefore be made of two events, both of which have taken place in 2011 in Torino, the first Italian capital city: the reorganization of the permanent Risorgimento Museum in the Palazzo Carignano and the temporary exhibition held at the disused train repair depot, the Officina Grandi Riparazioni. Both events, from different points of view, set value on the experience of the Risorgimento and national unification and invited reconsideration of a number of fundamental events and broader themes relative to the construction of the national state. But they did so in different ways.

The Museo del Risorgimento, located in the baroque Palazzo Carignano, incorporates the original room of the first Italian Parliament and makes large use of the 
existing collections. Its renovation, directed by academic historian Umberto Levra, has benefited from the law on the 150th anniversary celebrations and the relative funds, and it was strongly supported by the Piedmontese committee for the celebrations. The new staging is characterized both as a presentation of the Risorgimento as part of a larger European phenomenon and by strong self-reflectivity. Both the catalogue and the exhibits make the visitor highly aware of the strong influence of ideologies on the interpretations of Italy's unification and its musealization. Large pictures of the museum and exhibition rooms in 1908 and 1938 remind the visitor of how dated they were and help historicize the museum (Levra 2011).

In the new museum, the origins of the Risorgimento are not identified with the dynastic history of the Savoy kings, as happened under fascism, but rather with the Jacobin republics and the influence of the French revolutions. This is another way to locate it within a European picture, which becomes prominent especially in regard to the 1848 and 1870 revolutions. Hungary and Slovakia, as well as France, the United Kingdom, Germany and Spain are cited to suggest a European reading of the events that led up to the Risorgimento, but also to other national 'awakenings'. Moreover, the present museum ends with the nation-state prior to the Great War, thus erasing the final section of the previous permanent exhibition, which presented the Resistance as the Second Risorgimento according to the postWorld War II master narrative. It is the intention of the curator to develop the museum further in order to go beyond the brief but significant videos - well constructed with the help of international historians and presenting carefully chosen and appropriate images - and beyond the museum guide printed for the occasion, to furnish a deeper, and certainly more nuanced, interpretation of the Risorgimento. The museum's declared strategy is to operate at several levels, thereby adopting an approach that caters to different audiences; an approach that seemed successful, but not fully developed in the year of the museum's opening. However, the museology is quite traditional, as is the approach based on political history, with the addition of separate sections dedicated to culture and society, the age of the 'bourgeoisies' and the 'lower classes'.

Different considerations apply to the exhibition at the Officina Grandi Riparazioni in Torino, a temporary exhibition mounted in 2011 in an enormous space of industrial archaeology and consisting of thematic spaces containing objects, paintings, different sorts of multimedia panels with striking effects, moving images, film clips and soundtracks; in short, an impressive display. The exhibits fascinated children as they move their hands across a blackboard to see photographs of school classes and the different realities of literacy in Italy, and the public was intrigued and amused by novel and surprising spaces. In spite of these innovations at the Officina, the Risorgimento - instead of being presented as strongly embedded in a broad European dynamic - began in Italy, in 1815, in the Restoration following the Vienna Congress, as it does in very traditional historiography. This is a curious choice, especially considering the pool of historians and experts involved in the exhibition, many of whom were known for their interest in a more European periodization and for their innovative approaches. The choice, by the curators and historians Walter Barberis 
and Giovanni De Luna, seems to have been made for Piedmontese reasons. Torino was after all the first Italian capital city and the Risorgimento is obviously deeply intertwined with the history of Piedmont. Thus one would have read in the catalogue: 'The chronological order starts from the consideration that it was Carlo Alberto who launched the national movement.' This was a decidedly outmoded view. The catalogue's suggestion not to ignore the beginnings of a European Romantic culture, nor the insurrectionary ferment inspired by the French revolution, nor the sectarian and Masonic movements that were its cause and effect, did not seem sufficient to correct this approach, and they left the visitor somewhat perplexed. Only in the further sections of the exhibition was the attention paid to Italian political history compensated for by attention to what Italians read (as in the panel devoted to 'Italian books') or to 'the Italians and sport'. However, important themes such as education or emigration were treated with an abundance of documents and audio-visual exhibits, and also with scenic solutions.

In these Western European cases, except in Austria where the project is still in progress, attempts to organize new comprehensive national history museums have failed. Because the BELvue museum in Brussels and the Risorgimento museum in Torino are mostly devoted to the birth of the nation-state, they cannot therefore be considered exceptions. The latter is deeply rooted in the city of Torino and in its self-representation as the first Italian capital city. By no means aiming to present a comprehensive master narrative of Italian history as such, it adopts a traditional historical approach and considers a past defined by the French revolution and First World War. Going beyond the Risorgimento, however, seemed difficult, and in fact the choice was not to do so.

Overall, no consideration was made of the key issue of how to present in a permanent museum a different master narrative based on loyalty to the Italian republican constitution and intended to be more inclusive. Scant interest in investing money in a new museum while the existing ones (included Pompeii) were in a parlous state coincided with a phase of severe institutional and constitutional problems (the reform of the constitution under discussion for more than a decade being one of them), while crucial challenges such as the recent wave of immigration and the upsurge of racism broke the irenic picture of the italiani brava gente (literally 'Italians - good people') and created a difficult background for a museum of the history of the country as a whole. Once again, an overwhelming and difficult present prevented a broader historical gaze.

\section{Conclusions: back to history?}

Each of the cases considered in this chapter has its own story. However, some general (provisional) conclusions can be drawn. The solution of a comprehensive national history museum based on a one-sided top-down master narrative seems no longer feasible. In Alexander Payne's movie About Schmidt the retired insurance salesman Warren Schmidt (Jack Nicholson), at the end of his life, visits a history museum and compares his senseless life, which seems not to have made much 
difference to anyone, with the heroic pioneers who made the country great. A liquid, prosaic society with no ideals or depth seems to require comparison with a grand narrative. But this narrative is frozen in stereotypical images of a very traditional provincial museum. This does not seem to be the solution that European countries are seeking.

Networks or open museums (Becker 1998) dealing with different aspects of the country's history can probably better and more flexibly convey the complexity of each national history and be more respectful of the plurality of historical interpretations, non-dogmatic approaches, and critical views. They can also help people not used to reading history books to approach parts of the country's history and a more 'democratic' history. The use of consultative groups to redesign narratives in museums, which has been recommended by a number of reports (Lynch and Alberti 2010; Message 2007; Peers and Brown 2003; Thumim 2010), is certainly one path to follow in order to implement the best practices.

Moreover, in the larger picture of European history museums, presentism seems to dominate. On the one hand, it mirrors some of the problems of the present; on the other, it reflects them in a plurality of individual voices that coexist, conflict and are in the best cases presented one after the other, almost always with significant gaps.

The omnivorous archive of modernity seems to triumph, while the historian often disappears into the background, as if he or she were helpless in front of so many traces of the present. The distance from the older nineteenth-century museums could not be greater. Tony Bennett has insisted on the character of older museums as cathedrals of the nation opposite to the entertainment space of the fair and as examples of top-down knowledge (Bennett 1995). The shift of the notion of heritage from history to society, and from art and history to the notion of everyday individual life, is telling, as confirmed by exhibitions such as the Bazar $d u$ genre at the MuCEM, where the word bazar is significant. This trend is also embodied in proposals for museums without objects (Conn 2009), or even 'ubiquitous' ones where societies are represented through both art and anthropology, but history is significantly lacking (Canevacci 2013). It is these museums that seemingly embody both presentism and the liquid society (Baumann 2007), while the museum cathedral seems to collapse, or remains only in its outer shell as a new landmark in the city landscape.

However, other and contradictory examples have recently appeared, giving room to historians and to history.

In some cases, historians have made themselves heard directly in the museum. In the museum of the history of Marseille, which opened in 2013, the media do not give voice to the individual witness, with his/her presentist and pronouncedly individual approach; rather, they present the historians and let them speak and be seen. Thus, they make it possible to gain some distance and recover the centrality of a critical interpretation.

Other museums are changing their names, with the inclusion of the word, and hopefully the concept of, 'history'. This has happened in the case of the Cite de l'histoire de l'immigration and the Canadian Museum of History, which after the 
long debate already recalled, involving thousands of people, has taken this name and abandoned the one containing the term 'civilisation'. 'History - wrote Raphael Samuel in his Theatres of Memory - is not a prerogative of the historian [ ... ]. It is, rather, a social form of knowledge, the work ... of thousand different hands' (Samuel 1994: 8).

In identifying mythical elements in our own cultural and professional assumptions, we threaten our ethnocentric self-confidence. We discover a psychic dimension which recognizes the power of myth and unconscious desires as forces, not only in history, but in shaping our lives. We open up a history which refuses to be safely boxed away in card indexes or computer programs: which instead pivots on the active relationship between past and present, subjective and objective, poetic and political.

(Samuel and Thompson 1990: 5)

Is this the aim of those museums? Are they going to follow the steps of Rosenzweig and Thelen towards 'popular historymaking' (Rosenzweig and Thelen 1998; Jensen 2009), thus being at the core of a new public history? It is probably too early to tell. But the entire field of history museums, let alone of public history, will have to face the difficult balance between Mnemosyne and Clio.

\section{Notes}

1 www.sp.nl/opinies/769/Huis_van_de_Geschiedenis.html (accessed 7 August 2014).

2 In his presentation Du Musée canadien des civilizations au Musée canadien de l'histoire at the recent conference Exposer - s'exposer: De quoi le musée est-il contemporain? Exhibition inhibition: the museum of the modern world (Marseille - Mucem, December 2013) Jean-Marc Blais pointed out this change and explained it in terms of the need to set contemporary issues in a broader context.

\section{References}

Adeney Thomas, J. (2001) Reconfiguring Modernity. Concepts of Nature in Japanese Political Ideology, Berkeley, Los Angeles and London: University of California Press.

Anderson, B. (1991) Imagined Communities. Reflections on the Origins and Spread of Nationalism, London and New York: Verso.

Aronsson, P. and Elgenius, G. (eds.) (2011) Building National Museums in Europe 1750-2010, Eunamus Report No 1, Linköping: Linköping University Electronic Press.

Ashley, S.L.T. (2011) 'Negotiating narratives of Canada: circuit of communication analysis of the next Stop Freedom exhibition', Journal of Canadian Studies - Revue d'histoire canadienne, 45(2): 182-204.

Auer, E.M. (1983) 'Ein "Museum der Ersten und Zweiten Republik Österreichs": Dr Karl Renners Plan und erster Versuch', Wiener Geschichsblätter, 2: 53-80.

Baioni, M. (2012) 'Considerazioni a margine di un anniversario controverso', Passato e Presente, 86: 83-94.

Basso Peressut, L. and Pozzi, C. (2012) Museums in an Age of Migrations. Questions, Challenges, Perspectives, Milano: Politecnico.

Baumann, Z. (2007) Liquid Times. Living in an Age of Uncertainty, Cambridge: Polity. 
Becker, A. (1998) 'Musées ouverts, traces de guerre dans le paysage', in M.H. Joly and T. Compère-Morel (eds.) Des musées d'histoire pour l'avenir, Paris: Noesis.

Bell, C. and Napoleon, V. (eds.) (2008) First Nations Cultural Heritage and Law: Case Studies, Voices, and Perspectives, Vancouver: UBC Press.

Bennett, T. (1988) 'The exhibitionary complex', New Formations, 4: 73-102.

(1995) The Birth of the Museum. History, Theory, Politics, London and New York: Routledge.

Bennett, T., Trotter, R. and McAlear, D. (eds.) (1996) Museums and Citizenship: A Resource Book, South Brisbane: Memoirs of Queensland Museum.

Bentz, E. and Raffler, M. (2011) 'National museums in Austria', in P. Aronsson and G. Elgenius (eds.) Building National Museums in Europe 1750-2010, Eunamus Report No 1, Linköping: Linköping University Electronic Press, 21.

Berger, S. and Lorenz, C. (2008) The Contested Nation: Ethnicity, Class, Religion and Gender in National Histories, Basingstoke: Palgrave Macmillan.

Blom, I., Hagemann, K and Hall, C. (eds.) (2000) Gendered Nations. Nationalism and Gender Order in the Long Nineteenth Century, Oxford: Berg.

Boswell, D. and Evans, J. (1999) Representing the Nation: A Reader. Histories, Heritage and Museums, London: Routledge.

Bounia, A. and Stylianou-Lambert, T. (2003) 'War museums and photography', Museums and Society, 10(3): 183-96.

Bruckmüller, E. (1994) Österreichsbewusstsein im Wandel: Identität und Selbstverständniss in den 90er Jahren, Wien: Signum-Verlag.

_(1995) 'Millennium! - Millennium? Das Ostarrichi Anniversarium und die Österreichische Länderausstellung 1996', ÖGL, 39: 137-55.

Canevacci, M. (2013) 'Ubiquitous museum: exact imagination and digital communication between anthropologies, arts, architectures', key note speech (unpublished), Icom Rio de Janeiro, ICME.

Carandini, A. and Galli della Loggia, E. (2011) 'Idee per un museo della storia d'Italia' www. corriere.it/unita-italia-150/11_febbraio_21/carandini-galli-della-loggia-museo-storia-italia_ 039857c4-3dbf-11e0-8c41-24e78bec137b.shtml (accessed January 2014).

Cauvin, T. (2011) 'Quando è in gioco la Public History: musei, storici e riconciliazione politica nella Repubblica d'Irlanda', Memoria e Ricerca, 37: 53-71. English translation, www.fondazionecasadioriani.it $/$ modules.php?name $=M R \& o p=$ body\&id $=550$ (accessed January 2014).

Chevallier, D. (ed.) (2013) Métamorphoses des musées de société, Paris: La documentation Française.

Clifford, J. (1997) 'Museums as contact zones', in Routes: Travel and Translation in the Late Twentieth Century, Cambridge, MA: Harvard University Press.

Cohen, A. (2007) 'Quelles histoires pour un musée de l'Immigration à Paris! Mémoires plurielles, mémoires en conflict', Ethnologie française, 37(3): 401-8.

Conn, S. (2009) Do Museums Still Need Objects? Philadelphia: University of Pennsylvania Press.

Evans, R. and Marchal, G.P. (eds.) (2010) The Uses of the Middle Ages in Modern European States, History, Nationhood, and the Search for Origins, Basingstoke: Palgrave Macmillan.

Flacke, M. (ed.) (1998) Mythen der Nationen: ein europäisches Panorama, Berlin: DHM.

Fleming, D., Paine, C. and Rhodes, J. G. (eds.) (1993) Social History in Museums: A Handbook for Professionals, London: HMSO.

Frank, M.C. and Rippl, G. (eds.) (2007) Arbeit am Gedächtnis, München: Fink.

Gentile, E. (2001) Politics as Religion, Princeton: Princeton University Press.

Gruson, L. (2011) 'L'immigration dans les musées. Une comparaison internationale', Hommes E migrations, 1293: 12-21.

Guillaume, M. (1980) La politique du patrimoine, Paris: Galilée.

Hanisch, E. (2009) 'Der Beginn des Nationalstaatsparadigmas in Österreich nach 1945-der Unterschied zu Deutschland', in H.P. Hye, B. Mazohl and J.-P. Niederkorn (eds.) Nationalgeschichte als Artefakt. Zum Paradigma 'Nationalstaat' in den Historiographies Deutschlands, Italiens und Österreichs, Vienna: Verlag der Österr. Akad. Der Wiss. 
Hartog, F. (2002) Régimes d'historicité. Présentisme et expériences du temps, Paris: Seuil.

-(2013) Croire en l'histoire, Paris: Flammarion.

Henare, A. (2005) Museums, Anthropology and Imperial Exchange, Cambridge: Cambridge University Press.

Hicks, G. (2001) 'Natural history museums in the environmental age', in D. McIntyre and K. Wehner (eds.) National Museums: Negotiating Histories, Canberra: National Museum of Australia, 183-207.

Jensen, B.E. (2009) 'Usable pasts: comparing approaches to popular and public history', in P. Ashton and H. Kean (eds.) People and their Pasts: Public History Today, Basingstoke: Palgrave Macmillan, 42-56.

Johnston, W. (1991) Celebrations: The Cult of Anniversaries in Europe and the United States, New Brunswick: Transaction Publishers.

Joly, M.H. and Compère-Morel, T. (eds.) (1998) Des musées d'histoire pour l'avenir, Paris: Noesis.

Kirwan, A. (2011) 'Postcolonialism, ethnicity and the National Museum of Ireland' in P. Aronsson, S. Knell and A. Amundsen (eds) National Museums: New Studies From Around the World, London and New York: Routledge, 443-52.

La Mattina, G. (2013) “La schizofrenia austriaca”: gli storici e la questione identitaria', Passato e Presente, 90: 115-30.

Lanzarote Guiral, J.-M. (2012) “"Not just papers”: the 2007 Law of Historical Memory and the disputed heritage of the Spanish Civil War', paper presented at the inaugural conference of the Association of Critical Heritage Studies Gothenburg, 5-8 June.

Lejeune, P. (1975) Le pacte autobiographique, Paris: Seuil.

Levra, U. (ed.) (2011) Il museo nazionale del Risorgimento italiano di Torino, Milan: Electa.

Lleras, C. (2011) 'Facing up to diversity: Conversations at the National Museum of Colombia', in S. Knell, P. Aronsson and A. Amundsen (eds.) National Museums: New Studies from Around the World, London and New York: Routledge, 453-65.

Lynch, B.T. and Alberti, S.J.M.M. (2010) 'Legacies of prejudice: racism, co-production and radical trust in the museum', Museum Management and Curatorship, 25: 13-35.

Maier, C. (1993) 'A surfeit of memory? Reflections on history, melancholy and denial', History and Memory, 5(2): 136-51.

Mason, R. (2011) 'Representing Wales at the Museum of Welsh Life', in S. Knell, P. Aronsson and A. Amundsen (eds.) National Museums: New Studies From Around the World, London and New York: Routledge, 247-71.

Mazan, K. (2011) 'National museums in Poland', in P. Aronsson and G. Elgenius (eds.) Building National Museums in Europe 1750-2010, Eunamus Report No 1, Linköping: Linköping University Electronic Press, 667-87.

Melloni, A. (2011) 'Museo d' Italia, patto per il futuro', www.corriere.it/unita-italia-150/ 11_febbraio_22/melloni-museo-italia_2e365808-3e66-11e0-a025-f4888ad76c86.shtml.

Message, K. (2007) 'Meeting the challenges of the future? Museums and the public good', reCollections, 2(1): 71-93.

Meyer, P. (2013) 'Four narrative perspectives on Swiss history at the Swiss National Museum', in D. Poulot, F. Bodenstein and J.-M. Lanzarote Guiral (eds.) Great Narratives of the Past: Traditions and Revisions in National Museums, Conference Proceedings from Eunamus, European national Museums: Identity Politics, the Uses of the Past and the European Citizen, 519-30.

Mezzadra, S. and Neilson, B. (2013) Border as Method, or the Multiplication of Labor, Duke: Duke University Press.

Moretti, M. and Porciani, I. (2011) 'Italy's various Middle Ages', in R.J. Evans and G.P. Marchal (eds.) The Uses of the Middle Ages in Modern European States, History, Nationhood, and the Search for Origins, Basingstoke: Palgrave Macmillan, 177-96.

Murphy, M. (2007) 'La muséographie du "primitif' entre Paris et New York des années 1930 à nos jours', Cahiers parisiens, 3: 875-87.

Nora, P. (1982-94) Les lieux de mémoire, Paris: Gallimard. 
(1989) 'Between memory and history: Les lieux de mémoire', Representations, 26: 7-24.

O’Neill, M. (2013) A History Museum for all Canadians, www.civilization.ca/wp-content/ uploads/2013/09/mark-oneill-op-ed-e.pdf (accessed January 2014).

Pagani, C. (2013) 'La voce indiana in Campidoglio. Una lettura politica del National Museum of the American Indian', Passato e Presente, 89: 82-101.

Patriarca, S. (2013) Italian Vices from the Risorgimento to the Republic, Cambridge: Cambridge University Press.

Peers, L. and Brown, A.K. (eds.) (2003) Museums and Source Communities: A Routledge Reader, London: Routledge.

Phillips, R.B. (2011) Museum Pieces: Toward the Indigenation of Canadian Museums, Montreal, Kingston, London, Ithaca: McGill-Queen's University Press.

Porciani, I. (2008) 'Weaving the nation together: womens' traditional needlework as a rhetorical tool in national and regional discourse', in Y. Yannitsiotis, D. Lambropolou and C. Salvaterra (eds.) Rhetorics of Work, Pisa: Plus, 27-44.

(2012) 'Nations on display: history museums in Europe', in I. Porciani and J. Tollebeek (eds.) Setting the Standards: Institutions, Networks and Communities of National Historiography, Basingstoke: Palgrave Macmillan, 130-52.

Porciani, I. and Raphael, L. (eds.) (2010) Atlas of European Historiography: The Making of a Profession, 1800-2005, Basingstoke: Palgrave Macmillan.

Poulot, D. (2012a) 'Museums and history in contemporary France', in D. Poulot, F. Bodenstein and J.-M. Lanzarote Guiral (eds.) Great Narratives of the Past: Traditions and Revisions in National Museums, Conference Proceedings from Eunamus, European national Museums: Identity Politics, the Uses of the Past and the European Citizen, Paris 29 June-1 July and 25-26 November 2011, Linköping Conference Proceedings, n. 78, 2012, home/index.en. aspx?issue $=078,531-44$.

- (2012b) 'Preface: uses of the past - historical narratives and the museum', in D. Poulot, F. Bodenstein and J.-M. Lanzarote Guiral (eds.) Great Narratives of the Past: Traditions and Revisions in National Museums, Conference Proceedings from Eunamus, European national Museums: Identity Politics, the Uses of the Past and the European Citizen, 1-8.

Pratt, M. L. (1992) Imperial Eyes: Travel Writing and Transculturation, London: Routledge.

Rosenzweig, R. and Thelen, D. (1998) The Presence of the Pasts: Popular Uses of History in American Life, New York: Columbia University Press.

Samuel, R. (1994) Theatres of Memory: Past and Present in Contemporary Culture, London: Verso.

Samuel, R. and Thompson, P. (eds.) (1990) The Myths we Live By, London: Routledge.

Schiera, P. (2013) 'Per una storia costituzionale laica, su misura', Le carte e la storia, XIX: 5-20.

Simpson, M.G. (1996) Making Representations: Museums in the Post-Colonial Era, London: Taylor \& Francis.

Soldani, S. (2011) 'I centocinquant'anni di un paese in affanno', Passato e Presente, 83: 5-15.

Starn, R. (2005) 'A historian's brief guide to new museum studies', American Historical Review, 110: 68-98.

Stoke-Rees, E. (2011) 'Recounting history: constructing a national narrative in the Hong Kong Museum of History', in S. Knell, P. Aronsson and A. Amundsen (eds.) National Museums. New Studies from Around the World, London and New York: Routledge, 339-54.

Thumim, N. (2010) 'Self-representation in museums: therapy or democracy?', Critical Discourse Studies, 7(4): 291-304.

Tollebeek, J. (2010) 'Belgium', in I. Porciani and L. Raphael (eds.) Atlas of European Historiography: The Making of a Profession, 1800-2005, Basingstoke: Palgrave Macmillan, 137-40.

Tosatti, G. (2013) ' La storia istituzionale e il $150^{\circ}$ dell'unità', Le carte e la storia, 53(2): 53-66.

Troilo, S. (2011) 'National museums in Italy: a matter of multifaceted identity', in P. Aronsson and G. Elgenius (eds.) Building National Museums in Europe 1750-2010, Eunamus Report No 1, Linköping: Linköping University Electronic Press, 461-93.

Vanderlink, B. (2011) 'L'immigration dans les musées. Une comparaison internationale', Hommes et migrations, 1293: 86-95. 
Van Hasselt, G. (2011) 'Who authors the nation', in S. Knell, P. Aronsson and A. Amundsen (eds.) National Museums. New Studies from Around the World, London and New York: Routledge, 313-24.

Vukov, N. (2011) 'National Museums in Bulgaria: A story of identity politics and uses of the past', in P. Aronsson and G. Elgenius (eds.) Building National Museums in Europe 17502010, Eunamus Report No 1, Linköping: Linköping University Electronic Press, 133-50.

Witcomb, A. (2004) Re-Imagining the Museum. Beyond the Mausoleum, London: Taylor \& Francis. 



\section{PART III \\ Conclusions and national museum analysis}





\section{6}

\section{NATIONAL MUSEUMS AS NATIONAL SYMBOLS}

\section{A survey of strategic nation-building and identity politics; nations as symbolic regimes}

\section{Gabriella Elgenius}

This chapter will analyse national museums as significant national symbols and as nation-building devices. As part of the nexus of symbolism, used by elites as political tools, national museums raise awareness of, claim and contribute to the construction of national identities. National museums are uniquely placed as witnesses of nationbuilding, and illuminate, through collections and displays, that which Anderson (1991) identified as 'imagined' or Hobsbawm called an 'invented tradition' (Hobsbawm and Ranger 1992). They also highlight the crucial role of high culture in nation-building (Gellner 1983). As a comparative framework is useful here the inaugurations of the first national museum are analysed within their socio-political context and the 'politics of home' (Duyvendak 2011). Although national symbols are often misunderstood to be mainly decorative they represent at their core imaginations and interpretations of the nation's origin, its past, present and future. The current analysis leans on relevant frameworks developed out of a Durkheimian tradition (Durkheim 1976; Lukes 1975; Cohen 1995a; Turner 1967) with a focus on elementary forms of nation-building as the symbolic production of imagining the nation as one community. In today's world, nations use similar toolkits - they all have flags, anthems, national days, national museums and academies. Their role is, in other words, to demonstrate that nations are distinct, yet equal and on a par with other nations. With this in mind, we may assume that nation-building follows similar patterns and, even if the content of the proclaimed 'uniqueness' varies, claims to uniqueness appear to be less unique. National museums being no exception, they constitute strategic markers of nation-building introduced at pivotal times. As being of particular relevance here, this chapter provides a survey of the first national museums in Europe. (For the analysis of the ensemble of national museums as a concerted narrative see the second part of the conclusion, Chapter 7.)

Placing national museums in the context of other national symbols helps us to understand nation-building further. All national symbols are introduced at pivotal 
times in the nation's history, such as independence, the break-up of empires, the loss of empire, the forming of republics, kingdoms or unions. Studying national museums as part of wider national building strategies enables us to draw attention to nations as layered and to nation-building as strategic undertakings on behalf of state and identity politics. An interesting pattern of national symbolism emerges when we analyse national symbols in a systematic manner. The symbolic regimes approach highlights patterns of symbolic production and nations as symbolic regimes with the complexity, recyclable and ongoing nature of nation-building (Elgenius 2011a).

\section{National symbols as markers of nation-building}

It has long been recognized that nations are an important repository of symbols, whether in the form of golden ages, heroes and icons, capitals, public squares and statues, flags and anthems, national festivities, jubilees or commemorations, national museums and national academies, stamps and collections, war memorials or football teams. Symbols provide shortcuts to the groups they represent and are by nature referential, subjective and boundary-creating (Breuilly 1993; Cerulo 1995; Giddens 1991; Hobsbawm and Ranger 1992; Mosse 1975; Smith 2003). Therefore, considerable activity is found in connection with the introduction of markers, following the strategic use of symbols in identity and recognition politics, which is in turn connected to debates and struggles about membership, nationality, ethnicity, citizenship and integration. Many governments seem to have adopted a Durkheimian approach, hoping, for instance, that celebrations of nations will ultimately contribute to cohesion. Thus, not having a popular national day is increasingly perceived of as a problem. National symbols constitute interesting variables as they authenticate boundaries and promote domineering majority narratives of the imagined community in times when it is deemed necessary to do so by undermining challenging, diverse or marginalized histories. National museums authenticate boundaries against others, in particular by identifying the origins of groups as specifically national and by providing corresponding imaginations of nations as communities. In this sense they provide building blocks to nations that rely on continuous as well as ongoing reinforcement. The national museum is uniquely placed as an analytical variable in this context as an institution filled with objects that, in one way or another, claim to represent the nation. It makes sense, therefore, to analyse the introduction and establishment of museums within particular socio-political contexts that have something important to tell us about the trajectory of nations. National museums and other national symbols constitute nation-building tools for elites engaged in this process, as they, together with sundry national symbols, raise boundaries against others.

As the nation developed in modern times, with and after the French revolution in 1789 , it arrived on the political map with an emerging toolkit of awareness-raising measures and symbols. The geo-social community boundaries which emerged, blurred, undermined or challenged (Alba 2005; Cohen 1995b) depended on the manipulation and embellishment of their use. Historically and comparatively, pivotal 
times are associated with wars, conflicts, struggles for recognition and independence, state formations or the formation of unions.

Therefore, the production of symbols and national museums follows nationbuilding, and when the latter takes a turn the symbols that represent it usually do the same. National flags - as the oldest strata of the nation and a main national symbol - closely follow the declaration of independence and other pivotal or significant sovereignty dates, whereas national days emerge as an established tradition towards the end of the nineteenth century, helping to activate the nation. Specifically, out of 42 national days in a previous study, 11 were older than 1870, few of them with a national focus, whereas six appear during 1870-1914 (the period that, according to Hobsbawm, is characterized by mass inventions) and 25 were introduced after 1914. (See Elgenius (2011a: 199) on the establishment of national flags and national days). The corresponding situation with national museums is described below (see Figure 6.1).

The national museum is in this sense also an invented tradition that had been established by the middle of the eighteenth century and is established on the political scene earlier than national days (Elgenius 2011a, 2011b; Hylland Eriksen and Jenkins 2007; Hobsbawm and Ranger 1992), both variables contributing to perpetuate the nation as one community characterized by sameness, which involves

\section{National Museums by Periods of Nation-building}

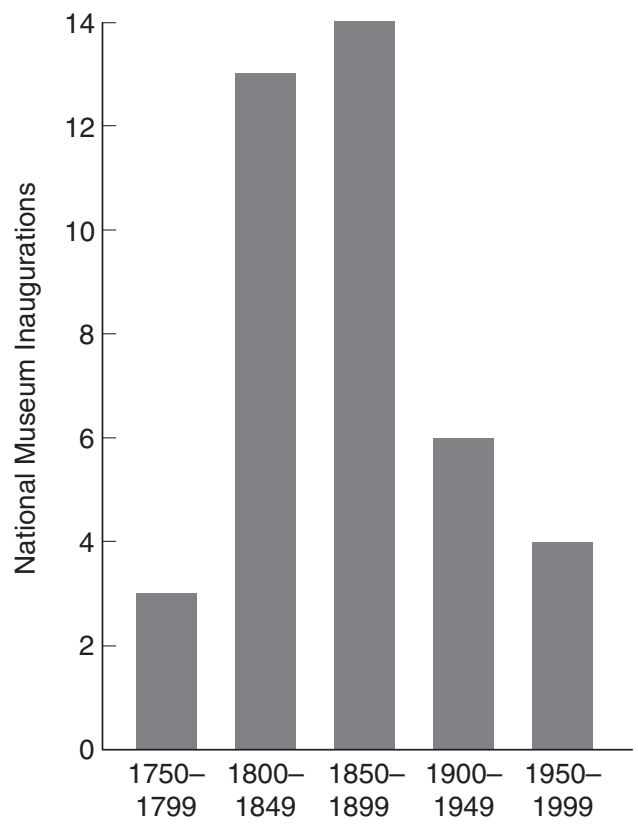

FIGURE 6.1 National museums by period. 
to 'do things together, take decisions, achieve results' (Miller 1995: 24). National museums in this manner help to justify the state and its sovereignty.

In other words, nations are layered with symbolism, and nation-building is continuous and ongoing and intimately connected to formation of states. National museums, like other national symbols, are introduced at pivotal times of nationbuilding as claimants of national communities that help justify the sovereignty of the state.

\section{National museums and high culture}

Nations intimate connection to the state is crucial in more ways than one. After the rise of modern nationalism and states and more inclusive notions of citizenship, nation-building was accompanied by the cultivation of a national culture and, with time, the musealization of cultural production (Knell et al. 2011). The state plays a significant role in the negotiations of national culture and helps set the framework for this. National museums are therefore highly useful tools in the analysis of nation-building processes, regardless of whether the past is defined or not. They are interesting as national institutions of culture that transferred and visualized the nation into the present through their institutions, buildings and careful selection of museum narratives. Clearly, national narratives are characterized by being narratives of dominant majority populations that marginalize competing strands of identities (Elgenius 2011a). Thus, it is not surprising that collections and displays have increasingly become objects of considerable negotiation.

With the endeavours of national museums in mind - as institutions, buildings, representations, displays and exhibitions - their activities are by nature boundarymaking enterprises. This means in turn that rival ambitions and exclusion lie at the heart of nation-building (Elgenius 2011b). Anderson's (1991) account of the imagined community did not originally specify what was actually imagined. National museums' help to illuminate that which is actually imagined may indirectly lead to ascertaining the contours of the nation. The establishment of the first national museums is therefore uniquely placed to shed light on both the institutions as imaginations and on the content of national imaginations that are at play in the first museum initiatives as well as the actual realization of public spaces. Gellner (1983) highlighted the radically altered relationship between culture and polity in the industrial society and the forces that worked for the fusion of culture and politics. He argued that these forces were indeed the essence of nationalism: 'A high culture pervades the whole society, defines it, and needs to be sustained by the polity. That is the secret of nationalism' (Gellner 1983: 18). Culture has become the necessary shared medium and is defined by the literate and educated (training-sustained) high culture (in a way that previous forms of a diversified, locality-tied and illiterate culture never could). In effect, nationalism can be defined as 'the striving to make culture and polity congruent, to endow a culture with its own political roof, and not more than one roof at that' (Gellner 1983: 43). The strong belief in museums as vehicles of citizens' education 
strengthens and integrates them into the educational system, as illustrated by many examples further on. For the purposes of this chapter, we may say that national museums provide a political roof over the nation's high culture nurtured by the state and state-led education.

For such reasons national museums have been analysed as cultural constitutions (see Chapter 7) interacting with political institutions, forming part of the institutionalized negotiations in which collections and displays come to represent national values and realities. Many of these negotiations and conflicts behind the scenes have long-standing trajectories; they are not arbitrarily chosen: on the contrary, they are part of the significant value production in the past two and a half centuries. National representations as articulated by national museums constitute powerful cultural forces with a decisive power to shape political communities. Since such representations are understood as knowledge-based they are hence presented as legitimate and factual. The functions and ambitions of the museums are related to the nature and character of the state and its educational process. The role of museums will be very different in the former empires or in nations without interrupted sovereignty compared to the nations in the midst of devolution or a struggle for independence. In short, history and culture is politics.

\section{National museums and strategic nation-building: a comparative survey}

As constituent parts of nation-building, representation and realization, we may expect that the inaugurations of the first national museums in Europe will contain significant data about this new tradition being established as a vessel for and of national ambitions.

Table 6.1 provides the underlying museum statistics to the timeline of first national museums (Figure 6.2), including: country and pivotal nation-building year, year and name of first national museum inauguration, major founding actors and the nature of their first collections' temporal reach. Table 6.1 lists the European countries by the second column and their national museum inauguration date but a comparative year of pivotal nation-building is also found (such as approximate dates of independence, state formation, formation of union, republics or kingdoms) in the first column. The second and third columns state the year and name of the first national museums (some of which may subsequently have changed their names and/or amalgamated with other museums and does not take note of all other changes that have happened). The fourth and fifth columns take into consideration major actors during the formative years as well as the temporal reach of the exhibitions. Compiling such data requires a process in which identical measures are applied and understood providing suitable material is available. We note that a great deal of information relating to nationand state-building is subject to interpretation, and that there are visible complexities in the definitions of the first national museums. 


\section{Timeline of First National Museums}

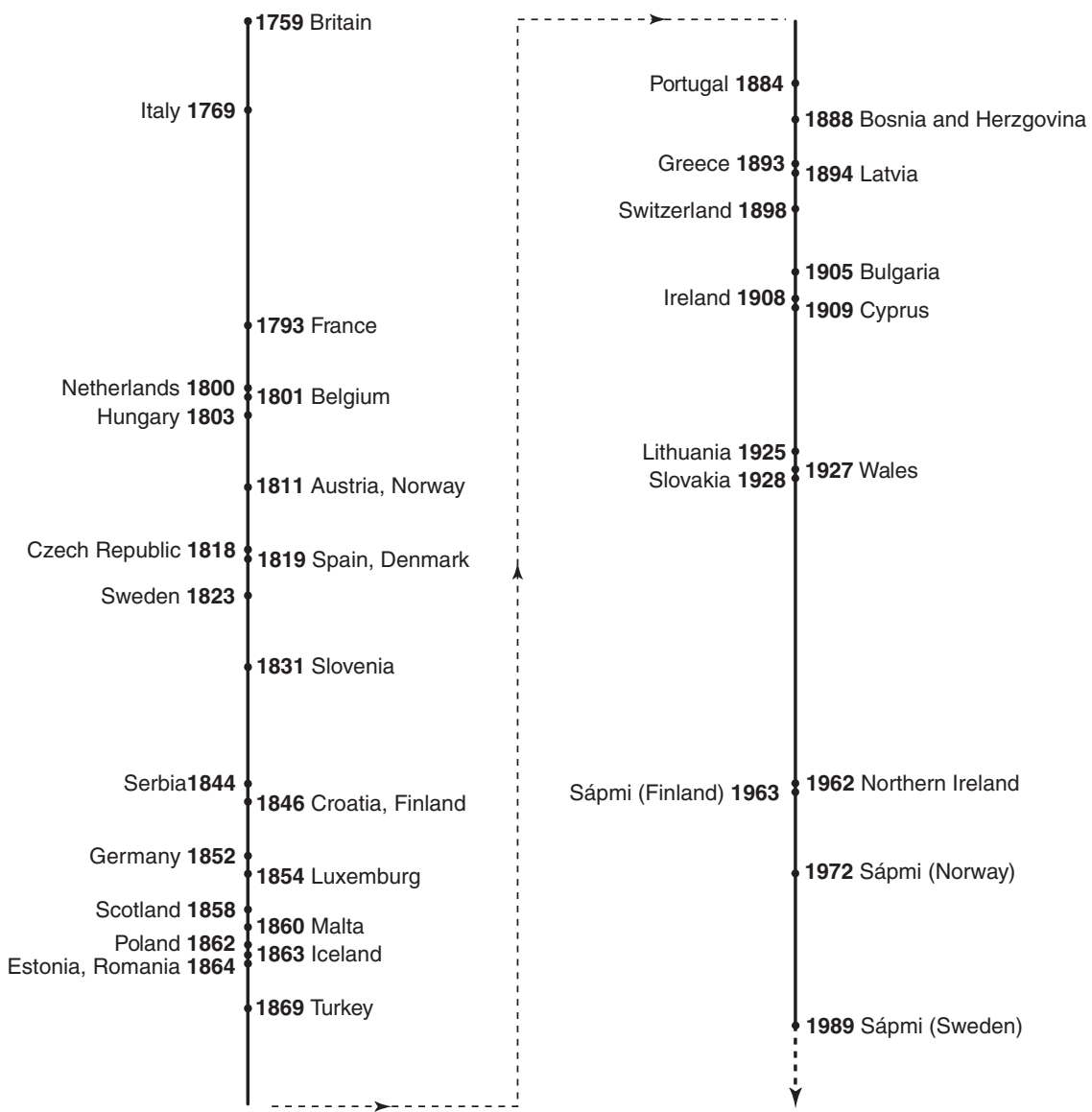

FIGURE 6.2 Timeline of first national museums.

\section{Pivotal dates and national museum inauguration (columns one-three, Table 6.1)}

National museums negotiate meanings of the past and hereby also set out to communicate the aspirations for the future, some imaginations being narrated successfully, others not. Historically speaking, considerable changes in symbolism have taken place, with major ruptures, opportunities or threats. In the context of European national symbolic production and expression, pivotal dates of nationbuilding are connected with challenges towards empires, the French revolution and the Napoleonic Wars, the two world wars, the fall of the Soviet Empire, devolution and globalization. With pivotal nation-building approximate dates of independence, state formation, formation of union, republics or kingdoms are 


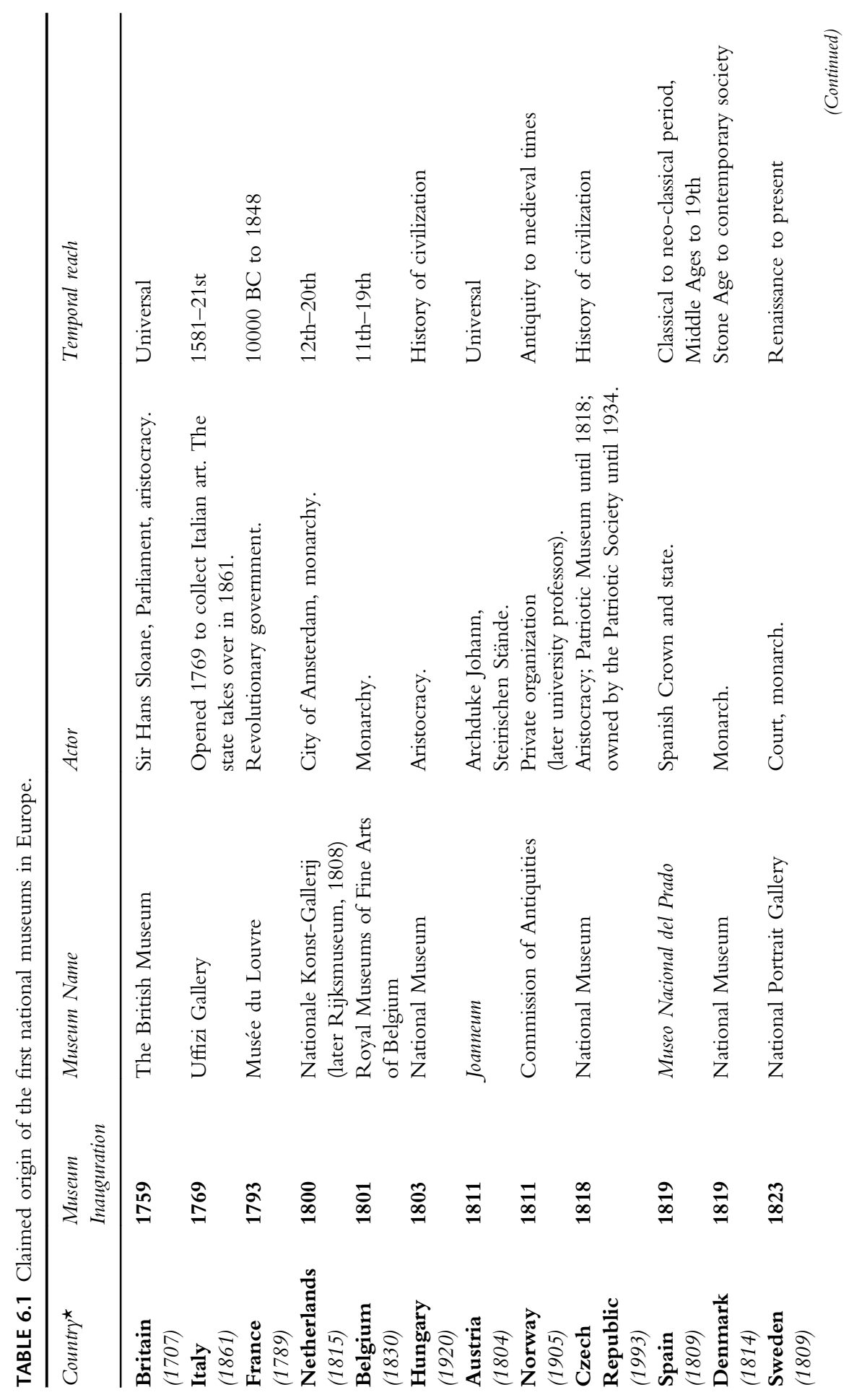




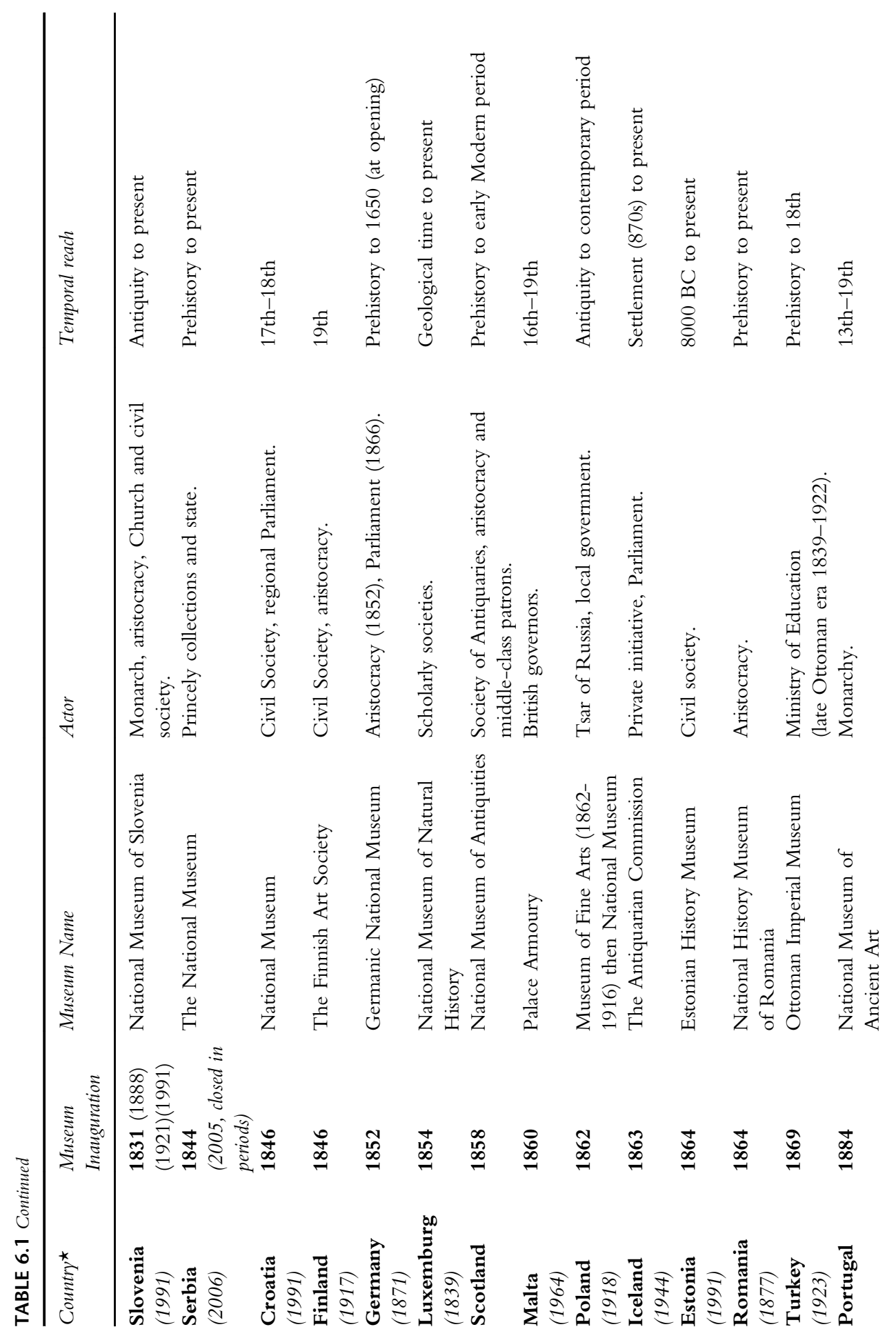



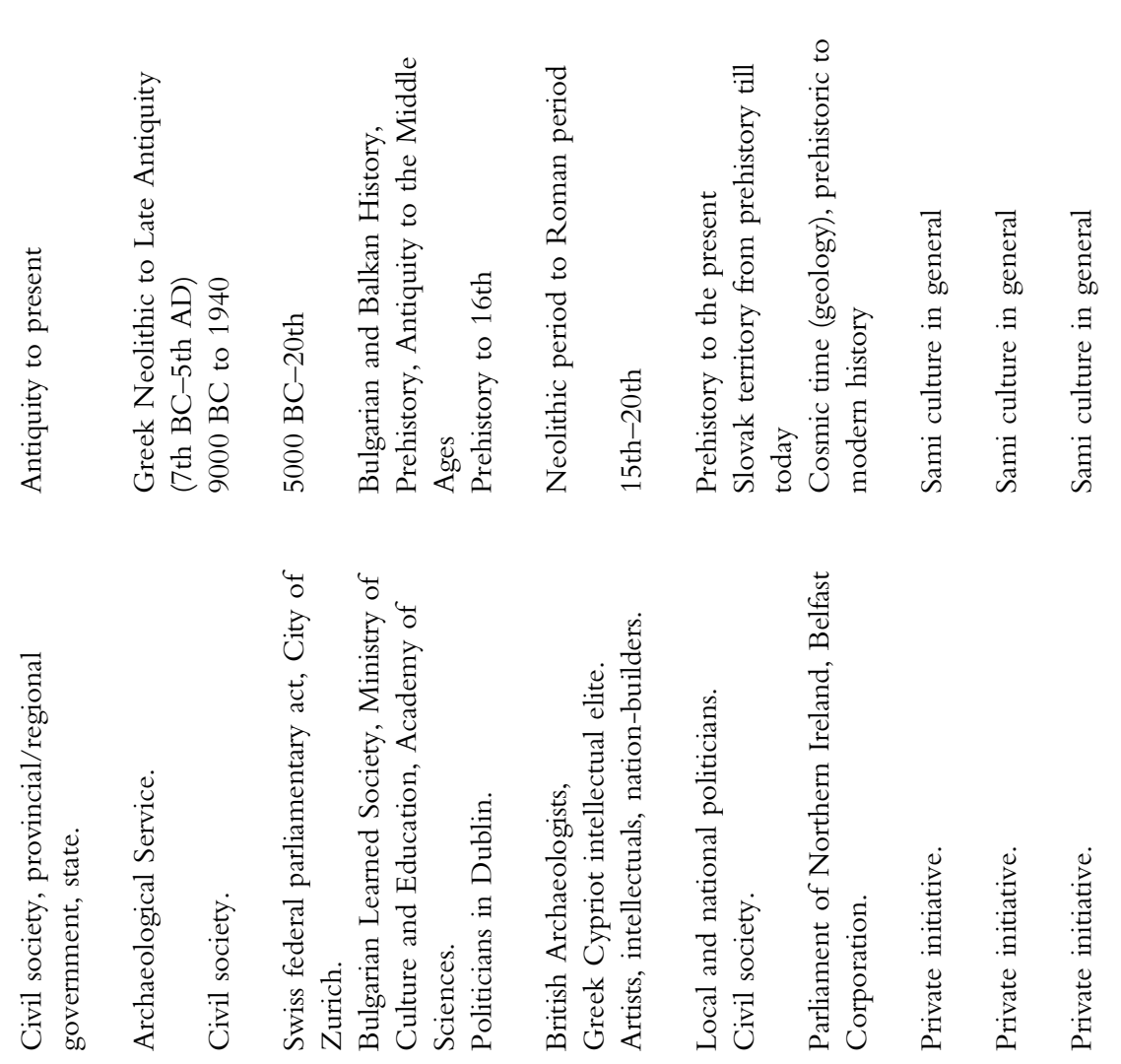

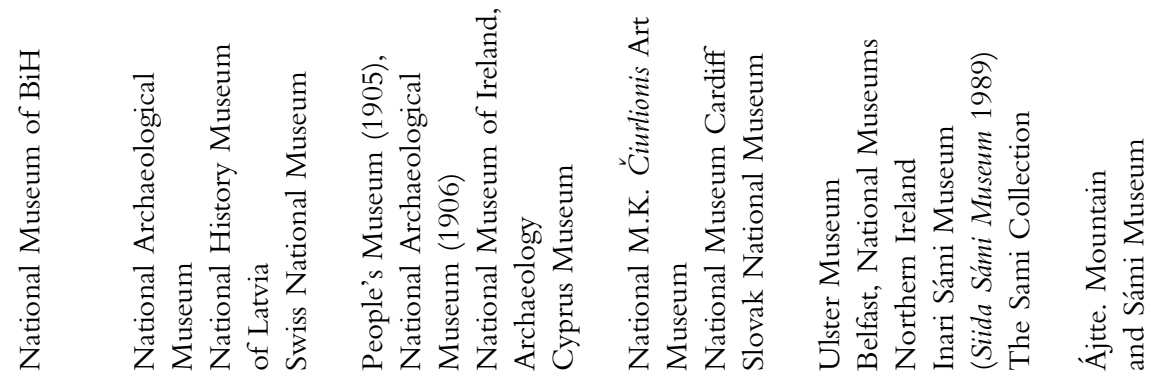

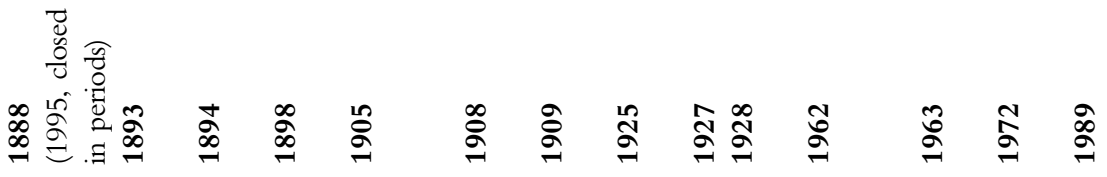

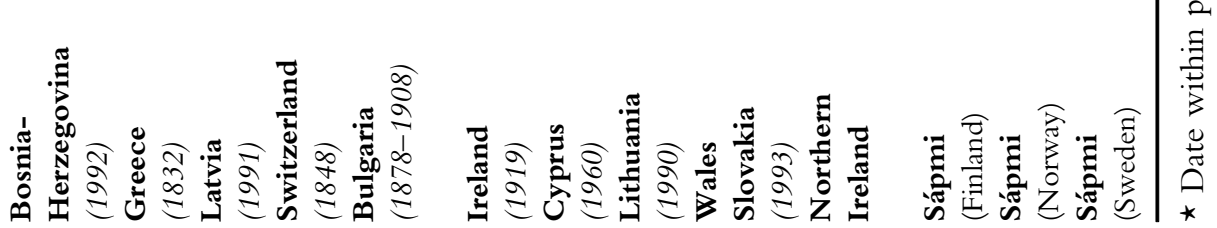


intended. In countries with pre-modern loyalties, however, there might not be one clear date (of independence) so museum development is analysed with the ambitions of modern nations in mind. In the case of museum development in France, this need be analysed with reference to the revolution of 1789 , by which the modern nation and republic was redefined. For other countries with premodern loyalties and with imperial ambitions such as Spain and Portugal, the Napoleonic Wars, following the American and French revolutions, impacted the Latin American Revolutions that, in turn, had a profound effect on Spain from 1809 and on Portugal from 1807 (see Lanzarote Guiral 2011; Bodenstein 2011d). The Portuguese monarchy fled to Brazil before the Napoleonic invasion until the return of the Crown in 1821 that was followed by formal Brazilian independence. Denmark and Sweden also suffered traumatic losses that helped redefine the core of these imperial states, as Sweden lost Finland in 1809 and Denmark lost Norway (to Sweden) in 1814 (see Widén 2011; Zipsane 2011).

This study has collected data about the first national museums and ranks countries according to the year of first museum inauguration, used as a concrete measure compared to initiation or founding. A few reflections on the table above will highlight the complexities, contrasts and controversies of nation-building and its interesting links to museum establishment. It is impossible to judge exactly when a museum turns into a national museum, taking into consideration the changing nature of the concepts of nations, national symbols and national museums that we are exploring. This is apparent at the very outset of the table, where naming the British Museum as the first national museum in Europe after a Scottish referendum in 2014 would not be to everyone's taste. The concepts of Britishness or British identity have occupied much of the public debate and academic pursuit especially with reference to nationality and citizenship (Heath et al. 2007). Historically, British identity is a relatively recent construct and dates from, at the earliest, the eighteenth century. It was gradually superimposed on the 'English', 'Welsh' and 'Scottish' following the 1707 Act of Union, after which the notion of a corresponding British identity was constructed supported by the development of the British Empire in the nineteenth century as summarized by Colley's title Britons: Forging the Nation 17071837 (Colley 2005; Peers 2004). Some see the opening of the British Museum in 1759 as an Enlightenment project aiming to protect and preserve knowledge and as such initiated by the aristocracy (Watson and Sawyer 2011). However, with the alleged crisis of a British identity in mind (Heath et al. 2007), the implicit imperial and supra-national ambitions - similar to national ambitions in the modern sense for the British Isles and the British Empire ought to be emphasized. Scotland obtained its own Parliament and Wales its own National Assembly in 1998. With regard to its imperial collections, the British museum has also generated controversy with the nationalization of colonial pursuits and the refusal to repatriate the cultural heritage of, for example, the Elgin or the Parthenon Marbles depending on perspective. Greece has repeatedly claimed the return of the Parthenon Marbles to their original home, whereas the British Museum has refused repatriation of the Elgin 
Marbles on the grounds of them being legally purchased in 1816 (before Greek independence). The two museums that followed the British Museum are the Uffizi Gallery in Italy (Florence) and the Musée du Louvre in France (Paris) and they also appear early on the political map of museums in Europe. The Uffizi opened in the pre-unification year of 1769 with the ambition to represent Italian art in a universal perspective and with a clear political agenda to glorify and legitimize personal patronages and sovereigns by the use of art. The Italian State inherited a great many regional collections as it took over control with increased national fervour with the unification of Italy in 1861 (Porciani 2012; Troilo 2011). The Musée du Louvre also demonstrates the close link between nation-building and museum initiation, as this museum was initiated and opened in 1793, a few years after the French revolution, by revolutionary elites who wished to renegotiate the propensities of the old royal France. The museum reflected the Enlightenment philosophy that had influenced its revolution. Still, the scope of the collections does today also display France's imperial past (Bodenstein 2011b).

It is clear that the national museum tradition had been established by the end of the nineteenth century (see Table 6.1 and Figure 6.2) with the age of nationalism and that national museums, like other national symbols, need to be studied in competing or rivalling clusters. Significantly, many of what are now considered national museums commenced their development as provincial museums within the empires of the time. Belgium's first national museum today - the Royal Museums of Fine Arts of Belgium - was inaugurated in 1801, 29 years before the establishment of the independent Belgian state and the Belgian monarchy (Bodenstein 2011a). As a museum, it was opened as a regional museum within the Austrian Empire and was later transformed and nationalized. The first museum in Austria - Joanneum - was inaugurated in 1811 during the Austrian Empire (1804-67). Most of the prominent Austrian museums were inaugurated during the two formative empires: the Austrian and the Austria-Hungarian (1867-1918) (Bentz and Raffler 2011). This is thus long before the more recent independence associated with Austria in 1955 when Austria achieved sovereignty with the Austrian State Treaty. The National Museum of Slovenia, as it is called today, was also founded as a provincial museum within the Austrian Empire and opened in 1831. Its provincial character was enforced with the different ruling units (Carniola, Styria, Carinthia, Gorizia-Gradisca and Istria) over the territories in which Slovenian was spoken (Dezman 2006: 9; Lozic 2011). During the first half of its existence, it operated as a provincial museum with the aim to improve the economic and cultural life of Carniola. The development of the region justified that the rule of the Austrian Empire as the core of culture in the Austrian imperial power was combined with the preservation of the presumed cultural authenticity of the province. Such relationships contributed to the solidification of an identity directly connected to Austria and Vienna as well as to the provincial locality. This seemingly complex relation between the provincial, imperial, pan-Slovene and pan-Slavic identities permeated the work of educational and cultural institutions 
until the very end of World War I. The museum became more of a pan-Slovene museum with the governance of the provincial government of Slovenia and the State of Slovenes, Croats and Serbs (followed by the Kingdom of Serbs, Croats and Slovenes renamed the Kingdom of Yugoslavia) and changed to the National Museum in Ljubljana in 1921. The emphasis to a national focus came with the establishment of the Republic of Slovenia in 1991.

As stated, national symbols are best studied in 'rivalling clusters' such as those that transpired out of rivalry surrounding national museum formation in Greece, Turkey and Cyprus. The Greek War of Independence from the Ottoman Empire ended in 1832. However, the narration of Greek nationalism was outlined in the second quarter of the nineteenth century and was moulded on the affinity to classical antiquity and a Byzantine heritage, supporting a master narrative of an 'eternal Hellenic spirit that guides the nation through different historical periods' (Gazi 2011: 363). The National Archaeological Museum in Greece opened in 1893 with the ambition to demonstrate a continuity with a glorious past and with a focus on origins ranging from the Greek Neolithic period to Late Antiquity (seventh century BC-fifth century AD). Archaeology has persistently aided the construction of Greek national identity on the basis of Greek antiquity, origins and roots. Museum formation in modern Turkey depend on what Shaw (2011) describes as multiple layers of national narratives (the layering of national symbolism is further discussed below) that express competing and sometimes contradictory narrations with the glorification of earlier periods but also distancing the republic from the Ottoman past. Thus, the museum construction in Turkey reflects the changing relationships between the state, the nation and museums, the latter functioning as a palimpsest within a centralized state. The multiplicity of identity production enables the coexistence of competing narratives deriving from the periods of the late Ottoman era (1839-1922); the early Republican era (1922-60); the era between two military regimes (1961-83), and the current period (1984-) (Shaw 2011). The oldest national museum is from the first period - the Ottoman Imperial Museum - and was opened in 1869 before the formation of the Republic Turkey in 1923. Sitting in between such rival historic and competing claims, the Cyprus National Museum opened in 1909 (initiated by the Greek Cypriot intellectual elite and British archaeologists) before independence from British rule in 1960. Museum-building in Cyprus falls into the characteristic periods reflecting the following narratives: 19th century-1955, claiming local ownership and distance from colonial rule and influence; 1955-1974, the commemoration of Greek and Turkish Cypriot suffering; 1974- manifestation of a growing sense of national identity (Bounia and Stylianou-Lambert 2011).

To add further complexity to our analysis, we turn to two national museums (inaugurated as provincial museums within the Austrian-Hungarian Empire also discussed above) and of particular interest in view of periods of closure in recent times. The closure of museums reminds us of narratives that are challenged, modified, undermined or unsuccessful. The national museums - in Bosnia-Herzegovina and Serbia - have been closed for significant periods since 1995 and 2005. The 
National Museum of Bosnia and Herzegovina was inaugurated in 1888, as another regional museum within the Austrian-Hungarian Empire and ten years after the Congress of Berlin in 1878 and the Austro-Hungarian Empire obtained administration of Bosnia and Herzegovina. The museum was established as the National Museum with the breakup of the Socialist Federal Republic of Yugoslavia in 1992. The 1992-5 war caused a break in its development and damage to the four buildings of the museum complex and to the botanical garden. It has been closed in periods since the end of the war in 1995 (Lozic 2011). The National Museum in Belgrade has gone through considerable changes since its opening in 1844 and has also been periodically closed since 2005. It was initially named the Serbian National Museum focusing on 'Serbian lands', acting as an important instrument in the cultural legitimization process of the Kingdom of Serbia's expansionistic policy (Pavlowitch 2002). The National Museum continued to pursue the policy of Yugoslavism as the official ideological agenda of the Kingdom of Yugoslavia in 1929 representing the Serbian master narrative. It is argued that Serbian Museum policies and narratives have rested on three different and contradictory paradigms: Serbian exceptionalism and uniqueness, a mediatory concept of national identity, and the reinterpretation of different historical processes (Manojlović-Pintar and Ignjatovic 2011). With regard to the first narrative, Smith argues that the ideology of Serbian nationalism was based on building the distance from the 'other' and restoring the memory based on the 'Golden Age' and its rise, fall and resurrection (Smith 2003).

Competative nation-building is also found in another rivalling cluster, Scandinavia. The intimate link between museums and nation-building, on the one hand, and the museum as an extension of the nation on the other, is demonstrated by the recent national museum formations and the claims by the transnational Sámi communities in Finland, Norway and Sweden with their recent national museum development of Sápmi (Amundsen 2011c). Sámi identity politics emerged in the 1970s, and the timing of the Sámi museums established in 1963, 1972 and 1989 must be understood as organized identity claims on the basis of political or cultural distinctiveness and on the grounds of unrighteous colonialization. This period has also seen the introduction of other national symbols such as the Sámi flag in 1986 and the Sámi national day introduced in 1992 and first celebrated in 1993. As hinted earlier, Nordic history is characterized by Denmark and Sweden trying to dominate their neighbours, which supra-national ambitions rather than stalling promoted nationalism in Norway, Finland and Iceland (Østergård 1997). The first national museum in the Nordic region - the Commission of Antiquities - opened in Norway as early as 1811 while Norway was still under Danish rule and three years before the Treaty of Kiel in 1814 when the rule was transferred to Sweden. By 1814 Norwegian nationalism had awakened and independence was achieved with the break-up of the enforced union with Sweden in 1905. In terms of museum-making, Norway was ahead of both its rivals Denmark (National Museum, 1819) and Sweden (National Portrait Gallery, 1823) but also before Finland (Finnish Art Society, 1846) and Iceland (Antiquarian Commission, 1863). 
(Norway is also ahead of the curve with regard to celebrating a national day, too, which constituted a mobilizing force for independence.) The timing of the museum institutions in Finland and Iceland are of great significance as socio-political statements before achieving sovereignty: Finland in 1917 and Iceland in 1944. In terms of museum-making, the Middle Ages had come to play a central role for modern Icelandic nationalism developing in the nineteenth and twentieth centuries placing Iceland as the Parthenon of European civilization (Hálfdanarson 2011: 53) as the Saga Age was compared to a generator of European culture similar to that of Ancient Greece (Sigurðsson and Ólason 2004). The return of the Saga Manuscripts (thousands of medieval manuscripts, fragments of manuscripts and documents) from Danish archives and collections became highly significant in Iceland during the nineteenth and twentieth centuries. This process commenced with informal requests in the 1830s and as a formal first claim in 1907. Claims were rebuked and thus repeated and extended with increased national fervour in 1924, 1930, 1938 and 1945. The year after independence (1944) Iceland demanded the return of all Saga Manuscripts including the Codex Regius and the largest Icelandic vellum Book of Flatey (Greenfield 2007). However, the whole repatriation process took around 90 years from the first formal claim to its completion in 1997 (Nielsen 2002). This is one of many examples of the repatriation of cultural heritage between national museums in the Nordic region that in tangible ways provide evidence of the politics of home (Duyvendak 2011).

The political museum map (Figure 6.3) correlates years of pivotal nation-building (state sovereignty/independence or other) with years of national museum inauguration. This shows nations in which national museums were inaugurated in a politically sovereign state (black) with those established in nations before independence had been achieved (grey) and those not yet independent (light grey). In countries that had achieved political sovereignty, national museums when established stabilized or legitimized states by transforming either royal or private collections into public museums. Those established in nations before sovereignty or independence (or related nation-building events) had been achieved received an instrumental role in preparing for the future. Provincial museums became involved in ongoing negotiations between the nature of the relationship between the central government and the province in federal or unitary states. Territories and identities in transition represented a vision of the sovereign nation. With regard to the past 20 years of museum narration, three distinct visionary and explicit museum utopias were found on the political level in Europe: the traditional national historical utopia, an emerging multicultural narrative one and what may be called a 'Eutopia' (Eilertsen and Amundsen 2012).

\section{Actors and temporal reach (columns four and five, Table 6.1)}

Nation-building elites in the past (monarchs and the aristocracy) clearly took museum-making seriously. This also applies to the new political elites having emerged via the forces of democratization. Museum-making originally engaged the 


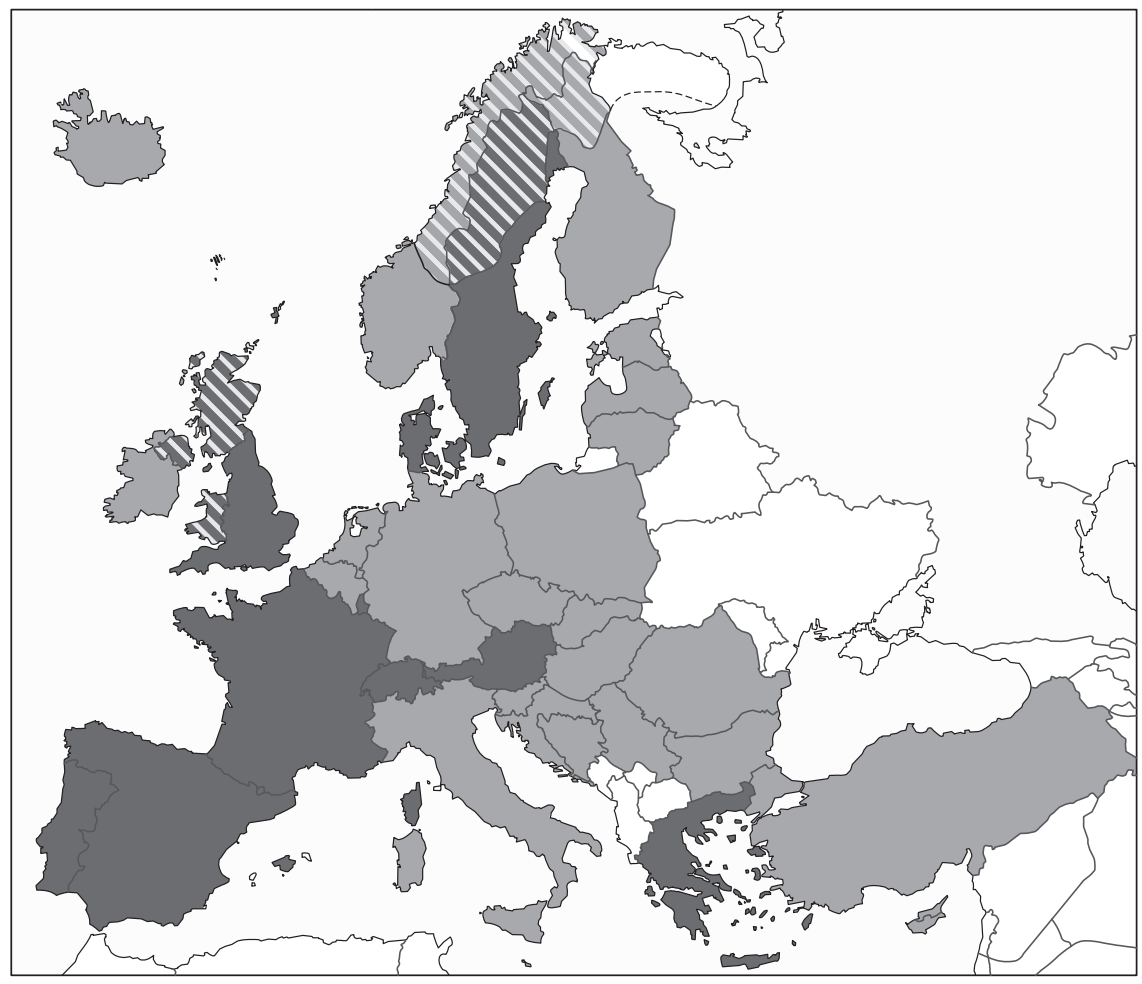

The political map above correlates the European countries 'years of of pivotal nation building' (state sovereignty/ independence or other) with 'years of national museum inauguration' (see Table 6.1 for details).

Nations in which national museums were inaugurated in a politically sovereign state

Nations in which national museums were established before independence had been achieved

Nations not independent but with established museums

Nations not part of this investigation

FIGURE 6.3 Political museum map: pivotal nation-building versus national museums establishment.

traditional elites but new political elites took over this role towards the end of the nineteenth century. Identifying the temporal reach of museum exhibitions, referred to as, for instance, 'universal' or as covering 'pre-history to modern times', carries indirect claims to the territory and helps to visualize imaginations of nations as ancient or even immemorial (Aronsson and Elgenius 2011a, 2011b). This is an aspect seldom transparent in the public debate, since nations are defined by their perceived or claimed past. In the case of European museums, they all display a history before the emergence of the modern nation. Clearly, such claims must be approached with caution but it is duly noted that national history, as claimed by nationalists and nation-builders, as distinctly national is at times portrayed along the lines of the immemorial nation (Smith 2003). Through the selection and display of collections, we find that these have been defined in terms the 'history of civilization' (Hungary), 
medieval, pre-modern, or ranging from $10000 \mathrm{BC}$ to 1848 (France), $8000 \mathrm{BC}$ to the present (Estonia), prehistory to early Christianity (Croatia), prehistory to the present (Serbia, Romania, Slovakia, Northern Ireland), the Stone Age to contemporary society (Denmark), Antiquity to the present (Slovenia), the eleventh to the nineteenth century (Belgium), or simply as 'universal' (Britain). Periods pointing to a glorious past may be part of such displays as with the focus on Greek Neolithic to Late Antiquity (seventh millennium BC to fifth AD) in Greece, antiquity to medieval times in Norway, 1200-1850 in Portugal or prehistory to the early modern period in Scotland. Continuity to territory may not be directly claimed but can be outlined through such exhibitions in ways that allude to the continuous occupancy of a given territory - a matter that seldom survives critical reflection.

\section{National museums and the symbolic regimes approach}

This chapter concludes by analysing nations as symbolic regimes. The symbolic regimes approach relies on the systematization of national symbols and various forms of symbolic production understanding national symbols as (a) markers of pivotal times of nation-building, by identifying (b) symbolic types and content, by exploring (c) the layeredness of symbolic production and by (d) the strategic use of symbols in identity politics.

In previous studies the recyclability of national symbols has also been studied along with the sequences by which nations claim and celebrate nationhood (Elgenius 2011a) but is beyond the scope of this presentation as is the conflicting pasts (Poulot et al. 2012a, 2012b) or the national museum ensemble that contribute to the concerted narrative discussed in the subsequent chapter (see also Aronsson and Gradén 2013; Porciani 2012).

\section{(a) National symbols are markers of nation-building}

The symbolic regimes approach is a comparative perspective of symbolic production originally developed on national flags, anthems and national days, whose introduction led us directly to the essence and complexity of nation-building. By dating symbolic origins, flags for instance, it was possible to shed light on interrupted or emerging nation-building with the break-up of empires, declarations of independence and sovereignty, with movements for autonomy or secessions and irredentism. Thus the adoption of flag symbolism have followed the revolutions (France), the formation of unions (Switzerland, Britain), transformations from monarchies to republics (the Netherlands, France, Italy, Russia) and vice versa (France 1814, Italy 1861), the Soviet Union domination (of the Baltic States and Central and Eastern Europe) and anti-communist transformations (with the removal of communist symbols) and fascist (Italy and Germany and their satellite states during the Second World War) and anti-fascist transformations (with the re-adoption of national flags). Many changes have also been recorded about the celebration of national days and these are also disrupted when their associations to the nations are contested, challenged and 
renegotiated. The symbolic battles over what may seem superficial details identify such symbols at the forefront of battles of and for nation and statehood. Most European national days are indeed celebrated in honour of founding moments: political events (independence, republics, union, sovereignty, constitution and liberation) (see Elgenius 2011a). Adding national museums help us to acertain information and complexities about pivotal nation-buliding although the patterns of flag - national day - and national museum symbolism are not identified. National museums are used in exactly the same manner: if introduced after achieved sovereignty they receive a stabilizing role, whereas those established before sovereignty (or related nation-building events) receive an instrumental role in raising boundaries as well as awareness of the nation-building process.

\section{(b) Different periods generate different types of narration and strands of symbolism}

Interesting patterns are found in clusters of national expression. Approaching nations as 'symbolic regimes' help us discover the contours of period specific symbolism formed on pre-modern (before 1789), modern (1798-1914) and post-imperial (1914-) narratives of these periods. This terminology relates to the types of symbolic expression linking it to the time it appears. Thus, whereas some nations (e.g. their flags) are represented by pre-modern religious and monarchical imagery, others reproduce the ideals of the modern and republican age. Postimperial images point, as a rule, towards an ancient past prior to actual and more recent state formations. For example, national flag types are linked to these periods: the cross flags with pre-modern origins, the modern tricolours and the postimperial heraldic or counter-nationalist flags. Many of the flags introduced in the post-imperial regime assert claims of independent nations after the First World War by means of medieval heraldic colours and devices. National days fall into two main groups: those honouring national personifications and golden ages are primarily religious holidays that have been nationalized or transformed into national ones, whereas the national days originating in 'modern' or 'post-imperial' times as a rule celebrate independence. In this context, the museum archetypes are the art museums and the historical museums that contribute to the expression, links to, visualization and imaginations of the past, present and future. The role of art and history museums in nation-building was analysed previously in Chapters 4 and 5. In reviewing Table 6.1 it is clear that these two museum types - art and history museums - fulfil a main role as the two unrivalled first types of national museums in Europe.

\section{(c) Nations are layered with symbolism}

In order to provide a context for the development of national museum as a nationbuilding device, the introduction of other national symbols also needs to be taken into account. The systematic analysis of national symbols highlights the layered 
structure of nations, the similarity of nation-building strategies and the strategic use of symbols in this process. As such when dates were produced for flags, anthems and national days, the historical sequences of nation-building are made visual for Europe (Elgenius 2011a). By adding now, national museums to the introduction of national flags and national days, various layers of symbols are uncovered. In comparison, using material produced elsewhere, we see the following: as a general rule, national flags appear before national days (and anthems in between the two). The flag constitutes the older stratum of the nation, the first national flags that survived into modern times appeared in the fourteenth century, whereas national days became an established tradition in the twentieth century. As the comparative components of museum-making are explored, the interaction between culture and politics remains striking as museums did not remain empty vessels (Hylland Eriksen and Jenkins 2007) once their potential had been realized. National museums are older than national days and, as per the results of Figure 6.1, 27 out of 40 national museums were opened in the nineteenth century, 13 of which were inaugurated in the first part of the century, 1800-49, which suggests that a museum tradition was established by the mid-nineteenth century and invented earlier as a national vehicle and pursuit than the tradition of celebrating national days. The layeredness of national museums are particularly interesting in clusters of rival ambitions or imperial pursuits often become transparent when studied in their rightful context, such as with the British Isles or the Nordic countries discussed earlier. The recyclability of symbolic and historical material is also a striking feature when exploring nations as symbolic regimes.

\section{(d) The strategic use of symbols in identity-politics; a recyclable pattern}

The first national museum has been used as a proxy for nation-building but also for successful nation-branding as these museums today are thought of as the first or most significant museum. It is clear that symbols based on historical material constitute part of the recycling strategy that aid nation-building. The old flags of Denmark (1340), England (1348), and Scotland (1385) were transformed into national flags and were clearly not originally national flags in the modern sense but constitute tools to think about the nation as old, given and necessary despite the fact that the concept of nationhood dating to more recent times. However, it is also a given that nations use symbols such as flags, museums and national days to claim their distinctiveness, which next to other distinctive nations or nationbranding strategies appear less distinctive. National museums have also become highly regulated by law and by state policy making, to various degrees, which may facilitate the support of domineering master narratives supported by states. The same applies to the use of national flags, for instance, which further suggests that there is a relationship between the symbol and the nation that is being protected. This is another dimension of the strategic undertakings and considerations involved in the fascinating and complex process that is nation-building. 
This chapter aims to provide a foundation for future research about national museums by analysing nations as symbolic regimes layered with strategically introduced symbolic devices. National museums constitute significant national symbols as part of the nexus of symbolic production - through which nations imagine and reimagine its boundaries and traditions. It is through national museums and other national symbols that nations become visible and remain imagined and may materialize in the achievement of political ambitions. As a systematic undertaking, national museums engage nationals, citizens, nation-builders and policy makers with yet another bricklayer of this majestic construction and building site that is the nation in this book and also illustrated by the cover.

\section{References}

Alba, R. (2005) 'Bright vs. blurred boundaries: second-generation assimilation and exclusion in France, Germany, and the United States', Ethnic and Racial Studies, 28(1).

Amundsen, A.B. (2011a) 'National Museums in Norway', in P. Aronsson and G. Elgenius (eds.) Building National Museums in Europe 1750-2010, Eunamus Report No 1, Linköping: Linköping University Electronic Press, 401-24.

- (2011b) 'National museums in Iceland' in P. Aronsson and G. Elgenius (eds.) Building National Museums in Europe 1750-2010, Eunamus Report No 1, Linköping: Linköping University Electronic Press, 425-34.

(2011c) 'National museums in Sápmi' in P. Aronsson and G. Elgenius (eds.) Building National Museums in Europe 1750-2010, Eunamus Report No 1, Linköping: Linköping University Electronic Press, 733-46.

Anderson, B. (1991) Imagined Communities: Reflections on the Origin and Spread of Nationalism, London: Verso.

Aronsson, P. and Bentz, E. (2011a) 'National museums in Germany: anchoring competing communities', in P. Aronsson and G. Elgenius (eds.) Building National Museums in Europe 1750-2010, Eunamus Report No 1, Linköping: Linköping University Electronic Press, $327-62$.

Aronsson, P. and Elgenius, G. (2011a) 'Making national museums in Europe - a comparative approach', in P. Aronsson and G. Elgenius (eds.) Building National Museums in Europe 1750-2010, Eunamus Report No 1, Linköping: Linköping University Electronic Press, 5-20.

_- (eds.) (2011b) Building National Museums in Europe 1750-2010, Eunamus Report No 1, Linköping: Linköping University Electronic Press.

Aronsson, P. and Gradén, L. (eds.) (2013) Performing Nordic Heritage: Everyday Practices and Institutional Culture, Burlington: Ashgate.

Bentz, E. and Raffler, M. (2011) 'National museums in Austria', in P. Aronsson and G. Elgenius (eds.) Building National Museums in Europe 1750-2010, Eunamus Report No 1, Linköping: Linköping University Electronic Press, 21-46.

Bodenstein, F. (2011a) 'National museums in Belgium', in P. Aronsson and G. Elgenius (eds.) Building National Museums in Europe 1750-2010, Eunamus Report No 1, Linköping: Linköping University Electronic Press, 47-68.

- (2011b) 'National museums in France', in P. Aronsson and G. Elgenius (eds.) Building National Museums in Europe 1750-2010, Eunamus Report No 1, Linköping: Linköping University Electronic Press, 289-326.

-(2011c) 'National museums in the Netherlands', in P. Aronsson and G. Elgenius (eds.) Building National Museums in Europe 1750-2010, Eunamus Report No 1, Linköping: Linköping University Electronic Press, 595-623. 
(2011d) 'National museums in Portugal', in P. Aronsson and G. Elgenius (eds.) Building National Museums in Europe 1750-2010, Eunamus Report No 1, Linköping: Linköping University Electronic Press, 689-712.

Bounia, A. and Stylianou-Lambert, T. (2011) 'National museums in Cyprus: a story of heritage and conflict', in P. Aronsson and G. Elgenius (eds.) Building National Museums in Europe 1750-2010, Eunamus Report No 1, Linköping: Linköping University Electronic Press, 363-99.

Breuilly, J. (1993) Nationalism and the State, 2nd edition, Manchester: Manchester University Press.

Cerulo, K. (1995) Identity Designs: The Sights and Sounds of a Nation, New Brunswick, NJ: Rutgers University Press.

Cohen, A. (1995a) The Symbolic Construction of Community, London: Routledge.

Cohen, R. (1995b) 'Fuzzy frontiers of identity: the British case', Social Identities, 1(62): 35-62.

Colley, L. (2005) Britons: Forging the Nation 1707-1837, Yale: Yale University Press.

Dezman, J. (2006) The Making of Slovenia, Ljubljana: National Museum of Contemporary History.

Durkheim, E. (1976) The Elementary Forms of the Religious Life, 2nd edition, London: George Allen and Unwin.

Duyvendak, J.W. (2011) The Politics of Home: Nostalgia and Belonging in Western Europe and the United States, Basingstoke: Palgrave Macmillan.

Eilertsen, L. and Amundsen, A.B. (eds.) (2012) Museum Policies in Europe 1990-2010: Negotiating Professional and Political Utopia [Electronic resource], Linköping: Linköping University Electronic Press.

Elgenius, G. (2007) 'The origin of European national flags', in T. Hylland Eriksen and R. Jenkins (eds.) Flag, Nation and Symbolism in Europe and America, Oxford: Routledge. (2009) 'Successful nation-building and ceremonial triumph: Constitution Day in Norway', in D. McCrone and G. McPherson (eds.) National Days: Constructing and Mobilising National Identity, Basingstoke: Palgrave Macmillan.

- (2011a) Symbols of Nations and Nationalism: Celebrating Nationhood, London: Palgrave Macmillan.

(2011b) 'The politics of recognition: symbols, nation-building and rival nationalism', Nations \& Nationalism, 17(2): 396-418.

Gazi, A. (2011) 'National museums in Greece: history, ideology, narratives', in P. Aronsson and G. Elgenius (eds.) Building National Museums in Europe 1750-2010, Eunamus Report No 1, Linköping: Linköping University Electronic Press, 363-99.

Gellner, E. (1983) Nations and Nationalism, Ithaca, NY: Cornell University Press.

Giddens, A. (1991) Modernity and Self-Identity: Self and Society in the Late Modern Age, Cambridge: Polity Press in association with Blackwell.

Greenfield, J. (2007) The Return of Cultural Treasures, Cambridge: Cambridge University Press.

Hálfdanarson, G. (2011) 'Interpreting the Nordic past: Icelandic medieval manuscripts and the construction of a modern nation', in R.J.W. Evans and G.P. Marchal (eds.) The Uses of the Middle Ages in Modern European States: History, Nationhood and the Search for Origins, New York: Palgrave Macmillan.

Heath, A., Martin, J. and Elgenius, G. (2007) 'Who do we think we are? The decline of traditional social identities', in A. Park, J. Curtice, K. Thomson, M. Phillips and M. Johnson (eds.) British Social Attitudes: the 23rd Report-Perspectives on a Changing Society, London: SAGE for the National Centre for Social Research.

Hobsbawm, E.J. and Ranger, T.O. (1992) The Invention of Tradition, Cambridge: Cambridge University Press.

Hylland Eriksen, T. and Jenkins, R. (eds.) (2007) Flag, Nation and Symbolism in Europe and America, Oxford: Routledge. 
Knell, S.J., Aronsson, P. and Amundsen, A. (eds.) (2011) National Museums: New Studies from Around the World, London: Routledge.

Lanzarote Guiral, J.M. (2011) 'National museums in Spain: a history of crown, church and people', in P. Aronsson and G. Elgenius (eds.) Building National Museums in Europe 1750-2010, Eunamus Report No 1, Linköping: Linköping University Electronic Press, 847-80.

Lozic, V. (2011) 'National museums in Bosnia-Herzegovina and Slovenia: a story of making "us", in P. Aronsson and G. Elgenius (eds.) Building National Museums in Europe 17502010, Eunamus Report No 1, Linköping: Linköping University Electronic Press.

Lukes, S. (1975) 'Political ritual and social integration', Sociology, 9: 289-308.

Manojlović-Pintar, O. and Ignjatović, A. (2011) 'National museums in Serbia: a story of intertwined identities', in P. Aronsson and G. Elgenius (eds.) Building National Museums in Europe 1750-2010, Eunamus Report No 1, Linköping: Linköping University Electronic Press, 779-815.

Miller, D. (1995) On Nationality, Oxford: Oxford University Press.

Mosse, G. (1975) The Nationalization of the Masses: Political Symbolism and Mass Movement in Germany from the Napoleonic Wars through the Third Reich, New York: Howard Fertig.

Nielsen, E.K. (2002) International Denmark to Iceland: A Case without Precedence: Delivering Back the Islandic Manuscripts 1971-1997, 68th IFLA Council and General Conference 18-24 August.

Østergård, U. (1997) Geopolitics of Nordic Identity from Composite States to Nation-states, www. ciaonet.org/wps/osu01.

Pavlowitch, S.K. (2002) Serbia: The History Behind the Name, London: Hurst.

Peers, D.M. (2004) 'Britain and empire', in C. Williams (ed.) A Companion to NineteenthCentury Britain, Malden, MA, and Oxford; Blackwell Publishing.

Porciani, I. (2012) 'Nations on display: history museums in Europe', in I. Porciani and J. Tollebeek (eds.) Setting the Standards: Institutions, Networks and Communities of National Historiography, Basingstoke: Palgrave Macmillan, 130-52.

Poulot, D., Bodenstein, F. and Lanzarote Guiral, J.M. (eds.) (2012a) Great Narratives of the Past [Electronic resource]: Traditions and Revisions in National Museums, Conference Proceedings from European National Museums: Identity Politics, the Uses of the Past and the European Citizen, Paris, 28 June-1 July \& 25-26 November, Linköping: Linköping University Electronic Press.

Poulot, D., Guiral, J.M.L. and Bodenstein, F. (eds.) (2012b) National Museums and the Negotiation of Difficult Pasts, Eunamus Report No 8, Linköping: Linköping University Electronic Press.

Sawyer, A. (2011) 'National museums in the Republic of Ireland', in P. Aronsson and G. Elgenius (eds.) Building National Museums in Europe 1750-2010, Eunamus Report No 1, Linköping: Linköping University Electronic Press, 435-60.

Shaw, W.M.K. (2011) 'National museums in the Republic of Turkey: palimpsests within a centralized state', in P. Aronsson and G. Elgenius (eds.) Building National Museums in Europe 1750-2010, Eunamus Report No 1, Linköping: Linköping University Electronic Press, 925-51.

Sigurðsson, G. and Ólason, V. (eds.) (2004) The Manuscripts of Iceland, Reykjavík: Árni Magnúson Institute.

Smith, A.D. (1998) Nationalism \& Modernism, London: Routledge.

-(2003) Chosen Peoples: Sacred Sources of National Identity, Oxford: Oxford University Press.

Troilo, S. (2011) 'National museums in Italy: a matter of multifaceted identity', in P. Aronsson and G. Elgenius (eds.) Building National Museums in Europe 1750-2010, Eunamus Report No 1, Linköping: Linköping University Electronic Press, 461-95.

Turner, V. (1967) Forest of Symbols, Ithaca: Cornell University Press.

Watson, S. and Sawyer, A. (2011) 'National museums in Britain', in P. Aronsson and G. Elgenius (eds.) Building National Museums in Europe 1750-2010, Eunamus Report No 1, Linköping: Linköping University Electronic Press, 99-132. 
166 Gabriella Elgenius

Widén, P. (2011) 'National museums in Sweden: a history of denied empire and a neutral state', in P. Aronsson and G. Elgenius (eds.) Building National Museums in Europe 1750-2010, Eunamus Report No 1, Linköping: Linköping University Electronic Press, 881-902.

Zipsane, H. (2011) 'On the development of national museums in Denmark', Eunamus Congress, Bologna, April 2011. 


\title{
7
}

\section{NATIONAL MUSEUMS AS CULTURAL CONSTITUTIONS}

\author{
Peter Aronsson
}

\section{Introduction}

All states have seen major threats, challenges and changes to their political constitution since the mid-nineteenth century. Everyday life has changed dramatically, with industrialization and urbanization raising living standards but also creating concerns relating to globalization, climate change and migration. In the past few decades, the end of the Cold War, the internet, the War on Terror and the EU project also connect everyday changes to high politics in new ways.

Despite these challenges, ideas of long-standing communities of cultures and values persist. People and communities have to deal with age-old dilemmas of how to balance difference and unity, change and stability. The relation between culture and politics varies depending on different political cultures, state-making trajectories and international contexts. In modern states, expanding welfare provisions interact with long-standing cultural institutions such as academies, school systems and national museums to play central roles previously carried by the Church. Systems of authority are again challenged through new media and the once again growing importance of religious justification.

Cultural representations act on change. This is observed in a wide range of theoretical approaches such as neo-Marxism, constructivism and post-structuralism, discourse analyses and traditions, often inspired by Michel Foucault or Bruno Latour where institutionalized culture and power are under scrutiny. Imagined communities (Anderson 1983) and invented traditions (Hobsbawm and Ranger 1992) have been paradigmatic for the critical constructivist approach to the making of culture as national heritage.

Taking this legacy of the linguistic turn back to the material and institutional culture and asking once again about the balance of persistence and plasticity in the role institutional culture plays in the making of policy, nations and states are issues at 
the heart of this chapter. The approach is to try out a concept of a cultural constitution interacting with its counterpart in the political sphere, political constitution. The aspiration is to suggest placing an equal theoretical emphasis on cultural and political dimensions in the making of legitimate power in a polity. First, the concept of cultural constitution will be constructed from its proximity to the better-researched sister, political constitutions. Second, mechanisms for negotiating values and contradictions of political importance in a central field of culture, research and communication will be explored. Third, ideal-type patterns of cultural constitutions will be formulated to better facilitate a discussion of the variation in the ability of cultural constitutions to interact constructively with political constitutions.

I argue that cultural institutions act as crucial and necessary intermediaries in providing the nexus for negotiating and working through these multidimensional tensions. Research on national museums gives us reason to believe that their establishment, anatomy and functions are dependent on: (1) the chronology and drama of the establishment of an independent state; (2) the relation between state and nation(s) formatted as conglomerate states, empires, federations, nation-states and state-aspiring nations; (3) the existence and working of spaces for autocratic or democratic decision-making, academic and professional influence, civil society and the public sphere in negotiations; and (4) the challenges of internal divisions derived from class, gender and regional differences or of external threats of war, occupation or deprivation (Aronsson 2011a).

By defining and utilizing cultural constitution as a concept, I will investigate and assess the validity and value of this concept as a frame for analysing the variety of modes whereby cultural and political constitutions interact. Not all modes of interaction are equally efficient, and I argue that assessing the differences between the cultural and the political constitutions in their capacity to interact can help in understanding difficulties in the making of the nation and state, when success is not only due to efficient economy, delivery of welfare goods or secure transactions in society, but also depends on its capacity to reach a high degree of understanding and trust between civic society and the political system. The level of relevant interaction and negotiations carried on between them will be emphasized as a positive value for developing high levels of trust between civic society and politics, which is necessary for a stable and creative polity to develop over time.

The role played by cultural institutions in using these negotiations to set up relevant arenas to act on and with is analysed in this chapter through the mapping and assessing of the power of national museums as a cultural institution born in and with the age of modernity, as already noticed by several scholars (Anderson 1993; Bennett 1995: 171-6).

In the Foucauldian tradition, Laurajane Smith has recently, and with great impact, launched the idea of the Authorized Heritage Discourse (AHD), where the dominant techniques of heritage work to stabilize political power and domesticate more vernacular heritage practices (Smith 2006; Hammami 2012). Perspectives from this critical tradition have provided an important corrective to a self-celebratory presentation of the ability of an Enlightenment institution to facilitate universal 
progress. There are, however, at least two reasons why the critical standpoint above needs a critique. More generally, it is a standpoint that locates the academic critique as positioning research itself outside culture, and hence paradoxically tends to reproduce the naivete of the positivist position, only differing in its stronger self enhancement by (over)emphasizing the role of critical research for societal change. This tendency, carried paradoxically by the constructivist approach, counteracts the merit of having opened otherwise invisible 'naturalized' fields of enquiry by neglecting the productive aspects of institutional culture for the sake of negative critique. This critical constructivist standpoint is so widely acknowledged among researchers and at risk to create a safe haven for indiscriminate negative assessments of institutional acts that it is in fact losing its ability to act truly critically (Sennett 1998; Aronsson 2007). More specifically, this leads to reductions and a less dynamic understanding of the way communication in the cultural web is being made, either by dichotomizing (vernacular - institutional or history - memory/heritage) or through a sole focus on critical evaluation (Lowenthal 1998; Nora and Kritzman 1996; Ho 2001). Thus, after opening a new critical space for research, it now threatens to make it difficult to research, discuss and assess different modes of how institutions can be successful in meeting cultural and political challenges. This field is left to consultants and at best to searching for 'best practice', instead of being fed by systematic comparative research.

My attempt is to demonstrate the ability of cultural research to productively work with normative issues without favourizing a particular cultural format a priori. Public use of the past and culture is persistent and variable. This ecosystem needs close and nuanced interaction with academic disciplines of culture which realize that they themselves are part of the historical culture analysed (Aronsson 2011b).

The cultural constitution arbitrates long-standing tensions between creativity and social cohesion, individual desires and social needs. In this chapter we will demonstrate the qualities of a specific segment of cultural institutions, namely national museums, in interacting with politics in negotiating long-standing dilemmas and acute traumas in the making of community, nations and states.

Negotiating cultural constitution has an ambiguous meaning that is deliberate and captures its flexible stability. On the one hand, cultural constitution is negotiated by many stakeholders over time and, on the other, it acts as a frame and scene for negotiations to be made. Negotiation develops both as indirect outcomes of discursive, functional and pragmatic interactions and as a result of formalized discussions and highly explicit cultural statements, such as national museums. It encompasses in its general conceptualization worldviews negotiated discursively, public political deliberations on the making of museums, as well as groups and institutions negotiating specific arrangements explicitly, such as the repatriation of human remains. Negotiations can be framed by the overlapping logics of epistemic, legal, political and public spheres. The complexity is one of the qualities mobilizing cultural capital in the social processes of bridging, bonding and binding communities across borders of logics (Szreter 2002; Putnam et al. 1992; Rothstein 2000). 
If successful, a dynamic community of trust and creativity is promoted. If not, disintegration and distrust create a society where energy and efforts are increasingly used non-productively in social, economic, cultural and political terms.

The empirical depth of the chapter draws on earlier research, adding original observations from the systematic comparative project European National Museums: Identity Politics, the Uses of the Past and the European Citizen (Eunamus, www.eunamus.eu). It stands clear that the variation and power of national museums can be understood in new ways by this comparative and historical approach (see Note 1, p. 196).

\section{Conceptual framing: national museums and constitutions}

The foundation of national museums was triggered by a fusion of impulses from the Enlightenment and national reactions to the Napoleonic Wars. Scientific as well as art collections had been a keen and prestigious activity of the learned classes and the aristocracy since the Renaissance. With the political and cultural challenges in post-revolutionary Europe, all nations quickly learned the need to establish a prestigious and visible materialized narrative of their progress in science, history, culture and art.

In 1806 the Danish antiquarian Rasmus Nyerup said that a national museum was needed as:

an asylum for slowly disappearing ancient national monuments ... a temple for the remains of the spirit, language, art and power of our past, where every patriot can study the successive advances of the nation's culture and customs.

(Bligaard 2000: 288)

The Dane shared an urgency that was felt to found national museums across Europe. The more ambitious and endangered the national project was, the more urgent the need for a cultural and material manifestation of its eternal existence. The trigger event was the expansionist Napoleonic Wars and the cultural politics that simultaneously gathered, valued and displayed conquered heritage as a victorious gesture, display of power and didactic move to promote the French nation (Bergvelt et al. 2009). Culture policy became an active mover, stabilizer and reaction to change, depending on the position of the nation in the flow of history, long before the policy sector acquired a standard label and a place in the family of governmental departments. Once created, national museums became long-standing nodes for negotiating change.

Germany provides an excellent illustration of the role and persistence of a national museum. The idea of Germany as a Holy Roman Empire of the German nation was defeated by military means in 1806 . The subsequent history of nationbuilding, empire, war, republic, Nazism, war, communism, liberal democracy, EU expansion and German unification seemingly demonstrates Germany as embodying the wisdom of Heraclitus: 'You cannot step into the same river twice.' 
Nevertheless, the idea of Germany as a distinct nation and culture survives as a frame of changing, but not completely replaced, set of values and representations. A rich set of national museums selects, nurtures and furthers this culture in Germany, with Berlin and Munich harbouring prominent ensembles of museums, but with the outstanding example of continuity and plasticity being the Germanisches Nationalmuseum founded in Nuremberg in 1852 (Aronsson and Bentz 2011).

Similarly, the dramatic evolution of Eastern and Central Europe in the nineteenth century and revolutionary changes in the twentieth century can demonstrate the existence of nations that are culturally represented or framed by very different states. Here, too, substantial continuities are formed, framed and carried by national cultural institutions, societies and movements (Hroch 2005; Smith 2001). A most important representation of these in terms of both symbolic and materialized legitimacy, it is here argued, is the national museum, which becomes a focal point for negotiating the national community. This institution is a primary actor in the cultural constitution of a nation, a long-standing representation of the understanding of the national community (Aronsson and Elgenius 2011b; Berger and Apor, Chapters 1 and 2 in this volume).

Originally a European invention, the national museum institution has spread all over the globe via empires. Post-colonial states took over the institutions and handled them as objects in transition, often adjusting with difficulty to new challenges in the post-colonial time. In the strong economies in Asia, investments in national museums are currently prioritized. In the migrant nations of New Zealand, Australia and Canada, the new museums negotiate ethnic and post-colonial relations. The new museum in Seoul, also used as a venue for high-profile political meetings with the OECD, demonstrates that nineteenth-century Budapest was not unique in summoning the Hungarian parliament in the National Museum (Knell et al. 2011).

The contemporary boom in heritage and museum-making seems to suggest an unbroken rise in hopes for the utility of these in negotiating progress and importance through museums (Message 2006; www.mela-project.eu). Yet, this conclusion would be rash, as there are plenty of examples where museums are absent, lose much of their relevance and fail to act on the cultural negotiations that need to be dealt with. This, too, has repercussions by affecting the stagnating relations between civic society and state institutions in parts of Europe.

\section{Defining national museums}

There is now a need to delineate the terminology and define what a national museum and a cultural constitution mean in the argument about the vital role cultural policy plays in the making of nations and states as long-standing institutions negotiating central dilemmas in the modern world.

By national museums we mean 'institutions, collections and displays claiming, articulating and representing dominant national values, myths and realities' (Aronsson and Elgenius 2011a). Hence, they are not defined by their nominal claims, formal patronage or funding, but rather identified as those museums, usually 
an assemblage of them, that fulfil the role together, successfully and legitimately acting as such over time. National museums thus need to be analysed as historic and contemporary processes of institutionalized negotiations of those values that will constitute the basis for national communities and for dynamic state formations. They are not just collections, exhibitions and buildings but also the material created in political utopias centred around museums, in the battles about what is the role and best practice of museums as well as in the mind of the visitors. ${ }^{1}$ This definition is not without difficulties since it relies on a complex assessment of their function and thus needs solid research to support the definition in each case. It is, however, appropriate to proceed to the argument of how cultural constitutions interact with politics, nation- and state-making to investigate the consequences of these relationships further.

To successfully convey the function of a national museum requires being able to negotiate and frame contradictory values and simultaneously show a solid façade of an immutable and impartial representation of truth. The dimensions to be negotiated range from a general worldview, the nature and realms of knowledge, via the representation of unity and difference, to the ability to handle change. All of these negotiations contain the structure of Aristotelian virtues: they are at work when they are able to promote socially situated judgements based on internalized values (Aronsson et al. 2001; Möller 2003; Österberg et al. 2012).

\section{Political constitutions}

Two very different ways of conceptualizing politics are to place them on a scale from insistence on adherence to formal procedures to the emphasis on a community of shared values. The first way would focus on the legal framework, starting with fundamental laws and moving on to the system protecting the rights of the individual. The latter could be divided into, on the one hand, emphasizing the capacity of politics to deliver goods, making political community a matter of rational choice, and, on the other hand, considering a coherent society to be the fundament of political organization. Strong standpoints have been made for the latter, on the nature on nationalisms, polarized between primordialists emphasizing the hereditary nature of community, and constructivists noting the active creation of nationalism and other traditions.

These ideals have repercussions on how to understand the history of nations and states, as the starting point will differ depending on whether you look for the existence of a unitary state, a legal framework, references to or the existence of a community, or a nation/nations organized by the state. For the purpose of the argument put forward here it is mainly the rationalist, formalist and modernist package that might challenge the idea of cultural constitutions as an important component or player in the making of nation-states. I argue, however, that this understanding of the nature of political society also is and needs to be culturally represented by choosing a presentation of progress, science and democratic values and by contrast making history more of a sad past story to be overcome by the 
power of modernity, as in discourses on 'the end of history' (Fukuyama 1992). Stressing primordial origin and ethnic community is not the only option. Universalism, secularism, human rights, democratic values, etc., are also culturally situated and therefore require a communitarian aspect - if they work as a foundation of community and cultural constitution. This has been stressed by postcolonial researchers but needs to be reiterated also within the confined frames of Western culture presenting itself (Post 2000; Aronsson 2012).

Thus, theories of constitutions, institutions, political culture and nationalisms can be and have been mobilized to argue and debate the nature of the relationship between formal politics and the cultures of the nation.

By political constitution we mean 'the body of doctrines and practices that form the fundamental organizing principle of a political state' (Encyclopaedia Britannica). Normative theory of good government began with Aristotle (Aristoteles 1993). Today, constitutional theory is marked by a normative drive to find the best legal framework for promoting democracy, answering questions about how stability and accountability can best be secured. On a more technical level, discussions deal with how the electoral system should be designed. What is the best division of labour and power between parliament, government, the president and the administrative and judicial system; central government, regional and local self-government? Some elements are discussed in greater detail than others: to what extent should processes be public, what should be the role of court decisions in framing or testing political decisions? In federal states, but also in nation-states and in the EU, questions of subsidiarity are debated (Sartori 1994). The process of enlarging the EU has for many states meant a stronger element of legal procedures in politics to harmonize and deal with conflicts between national political systems.

Dealing with heterogeneity lies at the heart of political constitutions. It can be dealt with by reverting all claims to universal and individual rights. These rights are, however, always restricted to belonging to a (political) community and sometimes acknowledge and grant rights to cultural communities based on religion, language or ethnic belonging. It has been noticed that cultural heterogeneity might or might not disturb a political community - language does in Canada, but not in Switzerland; religion does in Northern Ireland but not in the USA. Enquiries into political science move, however, too quickly from the question of how a legitimate presentation of a community is created, represented and upheld to issues of how a legal framework protecting and balancing heterogeneity and community, individual and collective rights should be best constructed (Post 2000).

Emphasizing this device for creating a good community is compliant with a contractual view of society and a procedural view of good government. The legal dimension can develop differently in cultures and theories that build on either natural, customary or positive law traditions. In the American tradition, a positive law and written contract broke with the English tradition of customary law but has acquired the strong valour of natural law as being of such a fundamental character as not to be alterable. In comparison, the fundamental laws of many countries are written with a conservative statute on how the contents cannot be changed 
without one public election in between, without the consent of a qualified majority, of both chambers, and so on, to underscore the consensus and stability carried by the constitution.

To summarize, constitutions often express procedural or ossified essential ideals of politics of a semi-stable nature, protecting natural rights against rapid and radical change or despotic rule. They are characterized by being explicit, regulating decision-making, demarcating the realm of politics from other spheres, and declaring how to deal with violations of statutes, all firmly framed by explicit laws and judicial systems that transcend the will of contemporary holders of power.

The idea of stability, demonstrated in different veins by the US (written) and the UK (common) law, is quite rare, since in Europe and - through the spread of colonialism - the rest of the world radical shifts between monarchy, republic and authoritarian governments have occurred in most places. Being hard and rigid also means having the property of easily being broken. Both written and unwritten constitutions do change, but the latter more by gradual shifts in decision-making that adapt to changing sensibilities in the legal and political system. A common law constitution is less deliberate in a contractual sense and closer to an organic, institutional or communitarian interpretation of society and change. Communitarianism, on the other hand, has a more organic approach to the understanding of society and nation (Etzioni 1995; Taylor et al. 1995).

These differences are also reflected in cultural and historical understandings of nation, nationalism and modernity. In arguing for the concept of cultural constitution, we are covering the middle ground opened by perspectives on politics developing by appreciating the power of political culture, attitudes, values and the arrangement of these in other bodies than political and judicial ones as suggested by institutional theory and governance perspectives. The advantage of the middle ground chosen here is to be able to discuss the role of cultural institutionalization as a creative ground for making culture political and politics into culture.

Institutional theory puts the focus on the dynamic force imbued in the values carried by institutions. Usually these are considered more in the social and political sphere - 'parapolitical space' (Horne 2002: 3418). Becoming political means socializing values through collective institutions. In this volume we argue that the national museum is a crucial institution in precisely this sense. It occupies a parapolitical space, and national museums in particular act as the most prestigious place for legitimizing the values of nature, culture, art and history. Although these values might be disseminated more effectively through other media, museums represent scientifically and politically sanctioned and culturally formatted knowledge - and present culturally formatted knowledge to legitimize the order and direction of society, nation and state.

Political culture as a way to appreciate the importance of attitudes and basic values for the working of politics has developed from Almond and Verba's pathbreaking work via Putnam to discussing the importance of both practical participation and widespread values and attitudes towards community and self-realization (Almond and Verba 1965; Putnam et al. 1992; Inglehart and Welzel 2005). 


\section{Cultural constitution}

The meaning of the term cultural constitution starts with the concept of culture as the totality of defining customs, values and attitudes. It discriminates in culture by picking out the elements most important to carry the burden of upholding an organized society over time. A constitution implies a static aspect of foundation, architecture, anatomy and persistence as well as a high degree of explicit articulation.

The concept draws here, however, first from the phenomenological understanding of how a perception or an understanding of reality is dependent on a context, a transcendent reality, for its appearance. The cultural constitution is understood as one modus of the 'cultural construction of reality' (Berger and Luckman 1967). The empirical presentation of the world in museums relies on a cultural constitution for the full realization of its meaning. The power of the concept lies in the combination of this dynamic and contextual aspect with the seemingly persuasive static materiality of the institutional presentation.

Defining the term 'cultural constitution' here also benefits from being done in relation to the much more widely used term 'political constitution', both because it draws its meaning from relating to this more widely used concept and because it makes it possible to consider how importantly they interact. The argument is that:

1. The cultural constitution of a nation-state provides the political constitution with long-standing, highly explicit and materialized evidence of shared history, culture and values understood as essential for the community circumscribed by the political constitution and providing a relevant value base for orchestrating directions to be taken by the community.

2. The cultural constitution is less formally secured, but at the same time more stable and flexible towards successive restructuring than the political constitution. It is also framed by laws but seldom defended in courts and parliaments. ${ }^{2}$ Instead, it is the public realms of museums, academic discourse and mediated debates that deliberate and negotiate through actions such as material collecting, display, education, dialogue and research, but also through outright political debate together with epistemic, aesthetic and ethical arguments.

3. The division of labour between museums regarding how they act on change differs on a scale from proactive via legitimizing/stabilizing to reactive. The way national museums are constructed and negotiate unity and handle diversity and conflicts, and their failure to do so, performs the cultural constitution and has repercussions for state and nation-making.

In this model (see also Table 7.1) the division of labour can be paralleled to the division of powers between, on one hand, the legislative, executive and judicial and, on the other, the working of the public sphere of independent media and civil society to keep a check on formal power. As there are different versions of constitutions, for example written and unwritten, monarchical and presidential, various chambers, and so on, there are also variations in the utilization of different types of 
TABLE 7.1

\begin{tabular}{lll}
\hline Modes of authority & Political constitution & Cultural constitution \\
\hline Articulation & Fundamental laws & National museums \\
Ontology & Procedural & Material \\
& Nominal & Community \\
Continuity/change & Discrete universal & Natural continuity \\
Negotiated & Judicial/elections & Science/public \\
\hline
\end{tabular}

museums to secure the cultural constitution. These are related to the two basic ways of constructing the bond between the nation and the state - cultural or civic nationalism - which has developed as different historical answers to similar challenges, but move beyond that since as a parapolitical arena the museum highlights scientific legitimacy as a more pertinent element.

The concept of cultural constitution has not been widely applied in earlier work. When used, it often refers to regulations of the level of politics to which cultural policy belongs. ${ }^{3}$ This is a much narrower capacity than is being dealt with here, specified to delineate the regulation within a political constitution of how and by whom cultural policy should be determined. This is needed in any political system with several levels, but most urgently in federal states, including recent developments in the EU. In those contexts cultural policy has often been a prerogative of provinces and not of the federal states. As culture has become an expanding field and more central to several other fields of politics, new regulations of shared commitments have been installed (Höglund 2012).

An interesting tension between the role of legal and cultural mechanisms to deal with conflict can be and has been argued. On the one hand, 'social complexity makes proximity impossible and ultimately shifts the burden of trust from culture onto law' (Delanty 2000: 126). Even when this sounds reasonable, a corollary should be that, on the other hand, a constant need for cultural representation is enhanced and institutionalized by this tendency, but there is surely a necessity to incorporate a wider variety of options at hand than the ethnically homogeneous cultural community. A growing tendency in the EU during the past 20 years to act on culture, while at the same time deploring shared judicial instruments to act on politics, seems to corroborate both observations (Miller 2012).

The relative importance of cultural institutions in the cultural constitution as such and the importance of the cultural versus the political constitution vary over time. For a pre-state nation, the formation of a national culture is decisive. In a smoothly operating market economy and homogeneous welfare society, culture might be so successfully integrated in civic institutions that there is little need for explicit demonstration. Polemic and propagandistic demonstration might be a sign of weakness and indeed has a contradictory effect, since any explicit propaganda simultaneously reveals a void that is supposed to be covered by demonstration and education. 


\section{Museum works}

The argument will now move to an inquiry into how culture and national museums relate to politics. National museums are important because they make explicit, endurable and collectively legitimate representations of culture.

Museums are complex artefacts initiated by active stakeholders in complex interaction because of the size, complexity and public nature of the undertaking. The meaning of national museums could and indeed needs to be multilayered, ambiguous and even contradictory. The balances to be struck here are of several kinds: to be useful the meaning carried by museums needs to achieve relevance for different agendas and yet not be openly contradictory; the representation needs to connect knowledge with political and social relevance without being exposed as propaganda or dismissed as irrelevant; it needs to be highly visible, symbolic, explicit and yet open enough both to the conflicts to be negotiated and to the change that is to be facilitated. The capacity to bring forward co-otherness ${ }^{4}$ capacities for museums to be read differently is great. Museums are multidimensional and material, forming hypertexts with more complexity than a political constitution or treaties.

The establishment of meaning and change is often played out by museums taking both a specific and possibly concerted role within a wider network of institutions and signifying practices. A division of labour is worked out to function in the wider realm of cultural policy and the more specific museum system, often quite different from the official policies and motives of culture, research and education.

By successfully managing the creation of publicly acknowledged meaning they act as disclosed agents of change by relating values, culture and politics to knowledge. This can be done in two fundamentally different ways: as a close representation of what is experienced, stabilizing the contemporary order of things, or with an ambition to pursue reality to move in a direction, to become a(nother) nation, to encompass other values than those that actually permeate its visionaries, proponents or visitors at present. Being a successful agent of change means managing to act through the logic of culture to achieve an impact beyond the cultural world, elevating the capacities of society to reflect its creative potentiality, dealing with both urgent and long-standing dilemmas, without losing the legitimacy that is the capital of the institutions (Bennett 2006; Aronsson 2011b).

\section{Negotiating politics through culture}

The power of national museums lies in their capacity to simultaneously perform several interconnected and seemingly contradictory manoeuvres. Tony Bennett emphasizes the working of identification and distinction, acting on the understanding and valuation of difference through both unconscious and explicit communication (Bennett 2006: 52-7). His label for this, the logic of culture, underlines the structural element of this work. To focus on the situational and negotiating aspect and relate it more strongly to its political implications, I use the concept of negotiating cultural constitution. 
The capacity of national museums to format the cultural constitution as a stabilizing component in relation to more revolutionary changes that are possible in the political sphere is a structural starting point. By emphasizing negotiation it brings out the dynamic element of a never-ending scene for re-evaluation of how to represent the world, society, humanity and the direction of history. Furthermore, the cultural constitution and museums are both a scene where deliberations take place, a deliberation about its formation and working, and a preliminary end result of negotiations.

The definition of a national museum means that the institution has an existence in cultural and political utopia, in debate, as concrete buildings and collections, as the implicit and explicit narratives told by buildings, artefacts, labels and catalogues, and finally in the experiences of audiences. It is this multimodal existence that makes the effect of negotiations multidimensional and a deep imprint of deliberative processes rather than exclusively the result of a smart director, a political decision or a scientific finding.

These negotiations act in interacting dimensions resulting in the factual representation of a worldview that, when successful, has managed to negotiate a general worldview, relate knowledge as a stable foundation for the direction of society and politics, negotiate the diversity of this unity and establish the role of the citizen. If this is pursued with relevance then it contributes strongly to handling change.

Let us now look more closely into the various dimensions and the various set-ups available to perform the constitutional negotiation in focus here. In the concluding part, these examples will be drawn together to an argument that two ideal-typical set-ups capture most of the positions, but the knack is to adapt them to the trajectory and situation of the specific setting the community in question is facing. I agree with Tony Bennett that good wishful ideas are not enough. There are definite limits to a constructivist approach to national representation. It needs to meet the experience of threats from and hopes of audiences. Failing to do so contributes to political failure, as with the Soviet empire, and gives rise to aggressive frustration in Western Europe in an age of global transition.

First, the main actors and motives in the making of national museums will be discussed. Then, the widest framing capacities of the institution will be mentioned and the division of labour connected to fields of action and academic disciplines will be outlined. When the stage is thus set, a grammar for negotiating capacities will be explored. The logical stratification does not represent a chronological chain of cause and effect but rather brings out the inherent relationship between knowledge and politics.

\section{Negotiating a vision}

Typically, there were two trajectories to the making of national museums before the twentieth-century democratic set-up. First, royal and aristocratic adjustment to liberal nationalism meant reinterpreting and donating the old assemblage of cabinets, galleries and collections to the service and representation of the nation rather than (only) the power and grandeur of the dynasty. 
In the age of democratic nationalism, second, the public space opened for cultural entrepreneurs to represent the call of the nation. The capacity of these to gain legitimacy as representing the nation needs a massive mobilization process that in itself represents the nation, adding value to the contents of the collection and the museum: Artur Hazelius's innovative open-air display of popular culture; the Society of Engineers establishing the Deutsches Museum in Munich as a mark of technology and science - Vorsprung durch Technik; returning entrepreneurs after 1989 being quicker than state institutions to reinvent the representation of historical distance as in the House of Terror in Budapest; neo-liberal capitalist families in Turkey investing heavily in national culture, as in the contemporary art museum Santralistanbul located at the likewise private Bilgi University.

In between royal and private initiatives, especially in the nineteenth century, academies were formed by elite circles, sometimes blessed as 'royal', but open to erudite participants in forms sometimes regarded as dangerously egalitarian. Today mega-museums and other market actors add to the set-up of prestigious museums to feed and export both national narratives and city branding (the Gulbenkian in Lisbon and elsewhere, the Hermitage in Amsterdam).

Among the formative actors were academic disciplines in the making. Many museums, such as the academic Berlin set-up forming Humboldt University, were integrated as part of the making of a modern research university. Empirical science, be it natural science, archaeology, ethnography or art history (to name the most prominent disciplines for the collection of artefacts) and history, grew in symbiosis with collections. Later on, they have been supplemented with educationalists, communication officers and market departments, which marks a move from being collection-centred to an audience focus in directing the energies of museums. Research and educational approaches are complemented or replaced by experienceoriented display.

In later phases of history these acting forces are often mixed but, typically, state responsibility for funding dominates even when foundations formally stay at least at arm's length, with a board of independent trustees, or with even more institutional distance as with the Smithsonian in the US or the Nordiska Museet in Sweden. For other museums there is a direct dependence on the government through ministries of culture, education or research. Some of the more centralized ones we find in southern Europe, as in Greece and Turkey. Military museums might sort under the ministry of defence and also follow a more outspoken and less diplomatic logic regarding even contemporary military conflicts.

Still, even in these countries the neo-liberal developments in the late twentieth century opened for new initiatives from civic society and powerful patrons in continuity with a nineteenth-century tradition of powerful private patrons. Not only the economic wealthy are active. As an example, in the former Eastern bloc, citizens' initiatives can mobilize memory around aspects of pride in the socialist era, when the official version ostracizes this as an evil foreign occupation or even as a plague (Badica 2008; Manojlović-Pintar and Ignjatović 2011; Sarkisova and Apor 2008). 
Major ruptures, opportunities and threats to nations and states change the vision: Napoleon, the world wars, the fall of the Soviet Empire, globalization and migration provide both old states and new nations with the need to remake the meaning of old institutions. This book provides a multitude of examples of how they act in changing conditions due to the situated circumstances available and chosen. The socialist intervention, to take just one example, was not implemented in exactly the same way in Eastern Europe, providing roads to negotiate national pride in the republics with a nominal Marxist/Soviet scheme, with outcomes ranging from Third Worldism in Yugoslavia, ideas on German anti-fascist continuity in the GDR, to cryptonationalism in republican disguise in the Baltic states.

The strong belief in museums as vehicles of citizens' education strengthened and integrated them as part of the educational system as much in the Western as the Eastern hemisphere. Centralized institutions were ready to turn the narrative around when political changes occurred after 1989; the then old Marxist stories could be literally exorcized as in Romania, but the building and exhibitions were radically reinterpreted to frame new national endeavours in a post-Marxist world (Badica 2008).

The Eunamus project summarized the past 20 years of intensive visionary acts on the explicit political level. In Europe we found three distinct utopias at work: a traditional national historical one, a multicultural one and a Eutopia (Eilertsen and Amundsen 2012). Relatively straightforward demands for cohesion and economic returns from pressured political leaders and dominating demands from the audience to satisfy traditional national recognition (Bounia et al. 2012) do not, however, exhaustively define the political role played by the persistent cultural institution, its professionals and exhibitions. An idea of democracy and dialogue is often high on the agenda for museum professionals, sometimes in tension with the more critical academic ideals of relevant disciplines. Truth claims, a demand for policy relevance and adequate representation are negotiated.

The variety of actors adds to both the trajectory and the dynamics expressed by the vision, mobilization and realization of the institution as such. The complex assemblage of actors furthermore necessitates a complex web of negotiations where overlapping and contradictory logics of science, the market, education and politics need to meet precisely because the materiality of the museum demands a seemingly unified outcome. This explains the multilayeredness that lurks behind the ostentatious conclusiveness of the building and the artefact.

\section{Framing a worldview}

The similarities demonstrated in the universal language of museums appear on several ontological and epistemological levels. Globalization and post-colonial critique have helped to unveil their European and historical specificity, but also their ongoing power to adapt and redefine values.

The most general level at work is in the presentation of a secular model of an empirically apprehended, scientifically founded worldview. This cosmological ambition acts on a similar level to religion, facilitating the translation from pastoral 
to governmental logic of power (Bennett, Chapter 3 in this volume). The division of the world into nature and culture, art and industry, culture and politics, us and them is not undisputed, but a starting point for most controversies not only in the childhood of modernity, but also today, and have hence become part of the grammar enabling cultural constitutions to be set to work.

The museum itself, both as an architectural building, located in a signifying cityscape of capitals and a practice performed by the many visitors, testifies to a commonly set grammar - however differently the 'parole', the actual speech act or performance, might vary with each visitor's unique experience. This is the way constitutions come alive and negotiate general meaning with situated experiences, back and forth. It is an empirical question whether and in what situations this works most effectively when not acknowledged or when openly and explicitly transferred.

The ambition of the research behind this book has been to look at both the articulate and the implicit working of museums, from the high and explicit utopian politics, via the making of institutions, actual collections and exhibitions, to the experience of visitors. At the most explicit and symbolic level, museums are national and political utopian objects to be realized, responses to perceived threats, as after the Napoleonic wars or in contemporary Europe, to deal with migration and ethnic diversity. Plans and ambitions for museums are also part of the political discussions that carry and explicate values about a good future. Political parties, museum professionals and the public might disagree on these and hence need to negotiate the huge public undertaking that a national museum is - a promise for the eternal future as there is no 'sell-by date', as well as to answer contemporary issues.

National museums and historiography alike, as central parts of the national historical culture, traditionally focus on difference, uniqueness and yet the unavoidability and progressive nature of the present state of affairs (Berger 2006). This in itself points to structural similarities in the way claims are made. These similarities are much deeper and a prerequisite for national museums to communicate (1) over time and (2) with an international audience to form part of the cultural diplomacy also managed by or moving in parallel to political ambassadors.

The buildings that embody these dreams are placed in the most prestigious parts of the nation, often in the capital, communicating their presence by adjoining institutions representing the political constitution (parliament, government, royal castle, high courts), older aristocratic ones (opera, theatre, academies) and more novel siblings (national libraries and archives, universities). The world order, prestigious centrality, relationships between justice, policy, power and culture are communicated and levelled above the everyday business of life and work of the nation to establish its otherworldliness and trans-historic character.

The architecture and city plan itself are part of the meaning: the neo-classical buildings of the nineteenth century give way to national Romantic elements and later to post-modern architecture, eternal values to national cohesion and the branding of metropolises (Knell et al. 2012). The shifts in architectural style demonstrate the aesthetic values of their time and are often shared by the international community, which underlines the transnational dimension of communication. Furthermore, 
the materiality and persistence of old buildings with added comments or radical new facilities by later epochs materialize the persistence of both the hosted culture and the ongoing endeavour to host it for the benefit of future heirs. The pyramid entrance to the Louvre, the many commemorative additions referring to the Holocaust in German institutions, the management of restoration on the Museumsinsel, Neues Museum, the reuse of the Old Parliament as a Historical Museum in Athens - all can be interpreted as carriers of more or less open statements addressing issues of history and change.

\section{Knowledge management and great narratives}

The birth of several disciplines (archaeology, art history, ethnology, anthropology, natural sciences) and the division of labour between these sanction and contribute to a narrative connecting departments of the museum and various national museums to the cosmologies and worldviews mentioned above as visions of the community and the world.

Typically, archaeology, through both materiality and interpretation, founded and grounded the community of territory, placing the beginning of history in a natural setting represented by and sometimes in the natural history museum, such as in Vienna. Archaeology relates to Big History and the evolution of mankind and places the findings both in the grand temporal setting and in the territorial community it claims to represent (Trigger 1989).

Archaeology became an innovative national science, especially north of the Alps where there was no classical heritage to connect to the great narrative of Western civilization. Prehistory expanded beyond Rome and adapted to an evolutionary theme of cultures and peoples moving from hunters and gatherers in the Palaeolithic to primitive farmers in the Neolithic Era, creating transEuropean trade, art and hierarchical society in the Bronze Age and, in the Iron Age, relating to Roman civilization through a national response, before finally entering the Middle Ages and history.

The baton of great narratives could then be passed on to history museums, if a proper state could successfully be claimed as the carrier of continuity, or to an ethnological museum if a more widely defined national culture needed to be assembled to guarantee the values of continuity and ancient origin, as was the case for many new states in the making in Eastern Europe.

In earlier Greek and Roman territories, the power of the classical heritage grew with the Renaissance and became vitally political in the national movements in Southern Europe in the nineteenth century. In Italy and Greece, the recovered heartlands of Rome, the identification of the ruling people created a dominant frame, while other states such as Spain, Portugal, France, Germany, Romania and Turkey, just to mention a few, had to incorporate and negotiate this piece of the past with a more secluded version of national history founded in popular culture, art and political history. A mode of art-historical representation became a strong genre for representing the former glory, legitimizing contemporary claims in these 
core territories and more ambivalently in other parts of Europe. Turkey after the Ottoman regime and the Kemalist revolution needed to create a more distanced relationship to this part of history. With Erdogan, AKP and EU-friendly policies a turn to a more positive view of the Ottoman period is evidently useful.

Ethnology and cultural history were thus an early resource used everywhere by ambitious nation-makers to interact with archaeology and anthropology in the making of a continuous and unitary national culture, but even more importantly to kick-start nations striving for statehood. In later stages of successful state formation, framed by political constitutions and unity, the same field demonstrates, orchestrates and domesticates regional and class differences. By culturalizing regional and class differences with the help of museums, what might have been or become politically contentious instead became a proof of the richness of national diversity. If successfully represented, it creates unity in diversity through the culturalization of potentially political interpretations of difference. In addition, cultural diversity can simultaneously display earlier forms of division, different ways of life and economy in 'the past' as a leisure activity to be viewed, or even role-played, on a Sunday afternoon, but at a safe distance of past presence (Bäckström 2011; Rentzhog 2007).

This is a 'universal' tool and function of the division of labour between cultural and political representations, often also between academic disciplines of ethnology/ anthropology and history. Culture interacts with the political narrative of history proper that surrounds the museum with a naturalized frame of national order founded within the contemporary borders of the state (or the anticipated borders to encompass the represented but not yet liberated nation). Talk of cultural unity is a language that can be accepted by both rulers and liberators, used in the Soviet bloc and today in discourses on ethnic minorities and multiculturalism. Culture is hoped to both work as a safety valve and as a domesticating manoeuvre to encompass differences and present a road to representation for the minorities by other means than political or economic rights.

This is an excellent example of an explicit demonstration in the museum that covers a necessarily more implicit power struggle. The balance between the cultural and political representation of the nation is struck by the balance between ambitions to create a new polity and the possible unity of cultural expression. It is difficult for this to take any other form than the comparative scientific approach in conglomerate states (the Habsburg Empire, the UK). Reproduced on a smaller scale, we find that the Czechs prefer the political narrative making Czechoslovakia into a possible end of history, while the Slovaks cultivated the cultural turn already offered during the Habsburg era to argue national independence both against claims from Greater Hungary (which did the same with Magyar culture in relation to Vienna) and the local Czech neighbour.

Museums of war and military museums have a role to play in most countries, mainly to enhance the bounded character of national community and the demanding historical bond with earlier generations of sacrifices. They are most central to new states emerging out of military struggles, such as Turkey, but also as monuments to sacrifice during the world wars (the UK, Russia) or as symbols of 
political unity in otherwise very diverse conglomerate states, as in Vienna. The opening to share communities of grief or even guilt transnationally is a novel reinterpretation witnessed in later years. The role of genocide and Holocaust museums, in spite of their ostentatious explicit message, has negotiable ambiguities as to the community they create and the values they pursue beyond the obvious 'this must never happen again'.

Museums of technology have double functions to play which are seldom decisive for national self-interpretation. Like museums of design, the V\&A being the role model, they are meant to inspire new explorations on the foundation of traditional skills. In some states that identify their glory with industrial and scientific revolutions they might play a more prominent role. This is the case with Bavaria in Germany, where the Deutsches Museum in Munich represents a modernist claim, later more prone to be cultivated also in museums of contemporary art such as the Moderna Museet in Sweden.

Art is an excellent arena for demonstrating universalized values of art and taste and at the same time placing the national uniqueness or possibly genius in an international context. From the Renaissance the classical heritage of Greek and Roman culture was understood as the benchmark for universal values of civilization. It became a resource for all ambitious collectors and triggered classical archaeology to explore the Mediterranean area for proofs of the golden age of Western civilization and the power of scientific enquiry in the new powerful imperial states. This created an ambiguous resource that made it possible for the Mediterranean nations to construct a national identification of continuity as legitimacy for new nations out of old empires or fragmented political orders dominated by imperial powers. On the other hand, the imperial states could use their resources to unearth, rescue and acquire prestigious items. The Parthenon frieze and the Berlin collection are the most debated, but smaller capitals also have their royal Glyptotech collections: Stockholm, Copenhagen, Cologne and Munich. The power and taste of the collector was simultaneously demonstrated - and is challenged by the later idea of national provenance as the natural context for heritage.

The field of art is generally more international and communicates with the market and civic taste to a much higher degree than national historical museums, which, through their direct connection to political legitimacy, are nurtured by laws of exclusive rights to antique artefacts. This brings a higher degree of sensibility to art museums, as regards both the level of taste and civilization and the competition to demonstrate power to amass the most valuable artefacts in the world. Under the auspices of universal artistic aesthetics, selections of material demonstrating colonial standpoints can survive in ways not possible for explicit colonial museums (Poulot, Chapter 4 in this volume).

The contemporary battle about the repatriation of art objects is a consequence of the nationalization even of art. The identification and hierarchy of national schools is one out of two scholarly outcomes of that development that still structures most national art galleries. The other one is the prominence of the genre of historical art in the nineteenth century. It survives to some extent in national portrait galleries and 
is still celebrated and alive in many countries demonstrating historical continuity and judgement to the recognition of leaders of culture, politics and economy.

Art has also survived as a language beyond identification with national schools or demonstrating a high level of civilization. With contemporary art it has become a tool to address difficult issues and act not only on cognitive but also on affective and emotive levels of consciousness, sometimes with a more open or ambiguous agenda.

Contemporary art museums have become the arena for national self-acclamation taking over what museums of cultural history represented a century ago. Competing for creativity combines more easily with a cosmopolitan, tourist-oriented and EU-friendly ambition than digging ever deeper into subtleties of the historical diversity of peasant culture. This approach, furthermore, negotiates the present transition into post-industrial society more effectively, while the museums of traditional rural culture negotiated the transition to modern industrial society by remembering the past, anchoring modernity in allegedly stable social forms.

This selective list of the utility and interplay between museums of various composition can only hint at the range of the potential and actually realized negotiations of social and political issues through the cognitive arrangement of departments and fields of exhibitions that has been and can be made through museums. These museums act along the full scale from representing a general worldview to relating to unspeakable traumata. In the middle ground, which will now be mapped more systematically, museums are potential resources for negotiating conflicts, where the tension between difference and unity is a standing issue. A grammar for negotiating capacities will be set to work. This is not exhaustive, of course, but exemplifies the type of negotiation that can be pursued within this institution as an example of the work framed by a cultural constitution.

\section{Negotiating difference and unity - conflict management}

By placing and dealing with difference as a cultural property it can be easier to manage than if it were conceived as an outright legal or political issue. This is one example of the intense interplay between politics and knowledge in the museums. Another is the translation of a culture to another department of the museum system. In the post-colonial world, the transformation of objects by repatriation and the transfer of cultural minorities from natural history to art or national museums in their own right is one dimension of the negotiation of cultural rights and the multicultural character of contemporary governance. This can only be done through the handling of difference by selecting one or a combination of possible strategies.

The capacity of museums to contribute to the handling of conflicts is one of its vital capabilities not only to make up a symbolic cultural constitution but also to act as one, since it lacks the tools of referendum, voting and court verdicts. This can be performed in several distinct ways, as is often done by a complex set-up of simultaneous performances.

Naturalizing the current state of affairs and order of things is the prime mode of handling divisions and demonstrating order and unity. Conflicts, contentious issues 
and alternatives to the present order are ignored and not discussed. This is a dominant mode for national museums demonstrating a non-partisan voice. This works well when consensus is strong and/or the underpinning knowledge is convincing.

Presenting reality beyond controversy needs to be handled with care and judgement to retain legitimacy and still cultivate topics of relevance, stressing the interest and urgency of the message. The division of the world into nature and culture, representing the voice of a national $W e$, sometimes universalized as civilization and reason, is part of this mode. It is challenged by the observable divisions of class, region, gender and age and the direction of evolution, which needs a more articulated approach to be credible and useful.

The easy way out, presenting superficial consensus by suppressing issues of great importance for development or of a highly contentious character, only means that they will undermine the role of the museum and will be dealt with elsewhere, in the parliament at best, as social unrest on the streets and violently, at worst, with civil war and genocide as the worst-case scenario.

Hence the central role played by a second mode of presentation of the world and especially society and history, as a meaningful orchestrated diversity. Difference is recognized, but domesticated into a concerted in varietate concordia, 'united in diversity' - as the official EU motto has put it since 2004 (Fornäs 2012). This mode of representation can enhance community and demonstrate unity without openly depicting an external enemy or threat. A functionalist frame keeps the presentation closed, self-contained and yet dynamic, adding to and reinforcing the (national) frame.

This mode is commonly used, first by exhibitions with a regional presentation of archaeological findings as pre-national signs of continuity, later with national popular culture to represent regional and class difference, and today frequently expanded to a sample of new immigration groups often selected through their status as Aboriginal and to the level of contention that needs to be overcome by expanding the understanding of who needs to be 'united in diversity'.

Visually, the standard exhibition in any national cultural museum in Europe and, indeed, the world will contain a sub-national regional mapping of prehistoric cultures and a celebration of regional folk costumes. The only hierarchy here is temporal - they all represent past conditions of life. Typically, archaeology presents evolutionary prehistory leading up to the present national frame, and folk culture acts as an anchor in a non-evolutionary static past of varieties of national culture.

The variety of folk culture is thus both celebrated, demonstrating beautiful handicraft, and put to rest as a historical fact, a predecessor of modernity with no political implications. Hence, this mode both recognizes and represents regional difference and possible ethnic minorities keeping the theme out of contentious contemporary issues. This technique has travelled with a stable aesthetic format and political function from eighteenth-century Europe, via Soviet cultural policy, to post-colonial settings.

Indeed, many demands from minorities to be represented better or more fully grow out of these nationally orchestrated exhibitions into their own museums, 
such as that of the Sami in Northern Europe, or the finalization of a full-fledged National Museum of the American Indian in Washington, DC. The latter with its 'National' label ambiguously points to the USA while thematically covering Indian communities all over the continent, hence negotiating minorities, the national and the empire all at the same time, in a setting where the minorities are on the rise, albeit from a very marginal position. The museum thus becomes an open source for functional integration in the USA, a hint of a transnational community of aboriginal organization and a herald of a phase of more activist approaches by each of the represented minorities. This brings us from the orchestrating mode to a group of more activist approaches.

When the museum defines communities and values more actively, the following modes contrast to the first in two ways which work within the scientific mode of representing, as it becomes openly activist and political. Within this frame there are quite different levels of visible and explicit activism.

Framing consensus is close to the naturalizing mode, but explicitly demonstrates communities of values to be promoted, and consequently demonstrates the possibility of not sharing them. Today, values of democracy and human rights are widely recognized as universal rights and consequently actively promoted in the democratic world. Within a certain culture this is more or less regarded as impossible to deny. Challenges to this do exist in totalitarian states, but also where religious belief challenges or takes over the role of scientific justification.

Working through past atrocities. Museums openly address conflicts, containing them with the museum as a tool together with the judicial and political system. The goal is to live with the past acknowledged questions of guilt with repercussions for the present, and to use cultural representation as a means to make a transition. In German there is a word Vergangenheitsbewältigung to signify this mode of coming to terms with the past (Rüsen 2002). Similar contemporary processes where national museums play a role are at work with the Sami people in Northern Europe, the Irish Troubles, conflicts between Maori and Pakeha, the British descendants, in New Zealand, truth commissions in South Africa, and so on.

Distancing for a new future. If the aim of the above use of the past is to learn by never forgetting, the goal here is to forget by moving the presence of the past from the present back into the past. The goal is to put the past behind to encompass a future free from it, but this is difficult to do without 'working through'. Stories of past external aggression are easier to deal with than dark sides of the history of the community itself. Creating a distance to history is intended to avoid having the past come back rapidly and silently in destructive modes (repatriation issues as part of post-colonial relations, Nazi and Soviet occupation, China-Japan conflicts). The celebration of the abolition of slavery is balanced differently in different nations between complete silence, working through legacies of racism and colonialism, and distancing oneself from this as a closed part of the past (Smith et al. 2011).

Representation to mobilize means representing past or current hostilities to make museums outright parts of political conflicts, which can easily be detrimental to their credibility outside a very specific context. Examples are more rare but often 
connected with militant conflicts such as in Balkan museums or Cyprus, the Kurdish issue in Turkey or South and North Korea.

\section{Powerful stories and failed relevance}

The ways in which national museums interact with conflicts and differences do not in themselves define how museums act on change. That dimension is the next and concluding variable to inspect. In terms of how the dynamics between museums and nation-making interact, four types of circumstances and contexts can be identified in which national museums stabilize, mobilize, react or fade in significance: ${ }^{5}$

1. Stabilizing national museums: most museums are usually part of inclusive, integrative strategies, but strategies might differ in the mix of recourse to universal values, ethnic assimilation and multicultural approaches as in Sweden, Britain and Canada.

2. Mobilizing national museums: utopian visions where museums are explicit tools for a new future, as materialized in Hungary and Poland in the nineteenth century, in Scotland in recent decades, in the emerging Sápmi nation, Holocaust museums across nations and the establishment of a European house of history in Brussels, all acting to promote values and new political communities.

3. Reactive national museums: these museums can respond to changes and challenges with demands on restitution of a past world order and can be part of a process of demanding the restitution of land, as happened openly in Turkey and Cyprus (or in non-European countries such as Korea and China). Calls for more straightforward ethnically-based majority national-historical museums in France, the Netherlands, Germany, Italy and Hungary exemplify a reactive stance to meet complex challenges of globalization and ongoing individuation.

4. Fading national museums and loss of relevance: national museums are not equally relevant everywhere and in all times. Some national museums exert little attraction on politics and the general public compared to the resources invested in them. For example, the new republics in the Baltic States after the First World War did not prioritize their museums, and in Sweden many national museums saw very little investment in the heyday of social democratic modernity, 1945-80s. The tourist-oriented museums of the classical heritage in Southern Europe have high aesthetic qualities but fail to work through the twentieth-century traumas of totalitarian legacies and hence contribute to the erosion of trust in the political system, rather than the opposite (Aronsson and Elgenius 2011a).

The mobilizing phase with more activist modes of using the past in shaping nations is a passing phase, whereas the stabilizing phase of normalized narratives is the rule and the loss of relevance a very real option - with troublesome consequences.

The layered development that is a consequence of the prestige of the national museum and the accumulated materiality of its anatomy necessitates a constant 
reinterpretation and re-presentation of the contents of the museum. The representation carries a less explicitly communicated dimension of continuity, lying implicit under the explicit narrative of any set of national museums eager to demonstrate progress and innovation. One recent and less predictable example of the power of cultural continuity in the midst of rapid political change concerns the consequences of Soviet influence on cultural policy in Eastern Europe. It supported centralization but allowed for regional institutional build-up with the label 'national' replaced only by 'republican', feeding the institutional framework with a superficially hidden national narrative even more strongly than the earlier republican period had managed to do. In countries such as Lithuania, Hungary, Bulgaria, Romania, the former Czechoslovakia and the former Yugoslavia, Marxism enhanced the structural growth in national museums as both an organizational and a narratological unity. Where strongly felt regional identities and earlier atrocities were denied cultural recognition and negotiation, dangerous tensions built up, as in Yugoslavia.

Although no working through of differences took place in other East-European states, implicit re-presentation was at least allowed. Ethnic narratives were in many countries accepted as part of that story, as a concession to regional variation, but were not allowed to be politicized. In fact, the latter reminds us of the technique of dealing with regional and ethnic minorities in the West, most visibly in the paradigmatic format of the open-air museum of Skansen in Stockholm. Here the intention was to represent diversity as a form of cultural richness within a given political frame leaving space for local pride, while domesticating and historicizing communal feelings and keeping them out of an explicit political agenda through a modernist evolutionary periodization. The communist ideology included a readymade philosophy of history with an even stronger evolutionary and teleological story to tell. The evolutionary starting point was shared by broad intellectual strata parallel to the social-historical turn in Western Europe. It was only with the writing of modern post-1989 history that the story of progress and the position of hero and villain was reversed. It is possible to keep intact such an ethos of progressivity by successively changing only the casting of the historical drama of national unification. The various paths of post-Soviet transition regarding violence and community trust should be fruitfully and more carefully evaluated in relation to the cultural logics built up by the diverse cultural constitutions (Sarkisova and Apor 2008; Rindzevičiūtė 2010; Aronsson and Elgenius 2011b).

\section{Ideal types of cultural constitutions}

The mix of initiatives and driving forces creating national museums reflects the dynamics of the evolving cultural constitutions that help shape the relationship between state and nation in each context. General patterns of two different ideal types of cultural constitutions can now be substantiated through the findings of Eunamus. As cultural constitutions work less with judicial tools and more with a multitude of forces and dimensions, metaphors of musical orchestration are used to capture the choices utilized to deal with different challenges. 


\section{The symphony}

Labels and conceptualizes a mode of highly orchestrated cultural constitution appearing in two very different settings: in strong centralized states where the national coherence and power is not disturbed by regional or imperial diversity or reflects a utopian adjuration expressed by stakeholders in a fragmented and threatened national context. A unitary ideal type of national museum typically displays a long coherent and all-inclusive narrative from the beginning of time until today, encompassing nature, archaeology, history, art and industry. We find such museums in, for example, Finland, Denmark, Wales and Hungary.

If the state was a crucial actor in establishing the legitimacy of the nation, it might continue to carefully invest in the representation of its power. The latter is verified by the development of national museums in, for example, France, Turkey, Finland and Greece and by the contrasting situation in Sweden, England and Switzerland.

It is not only the revolutionary cases that present the possibility for rapid transformation and a unitary narrative. A perceived and vital threat coupled with a strongly centralized political structure was the case of many nations in post-Napoleonic Europe, even for an otherwise stable state structure, such as Denmark, which not unexpectedly produced similar results.

Where one of the above-mentioned prerequisites of centralization and perceived threats is missing, the narrative will deviate from this unitary ideal type. More often than not the unitarianism of the constitution has the character of an invocation, which can be either powerful, formatting the polity, or eroded to an empty formula, depending on how well it is performed and able to interact with political and economic powers.

The symphony may, however, have a varied set-up of movements. Often there is a simple dichotomy or trichotomy of (1) ethnic, (2) multicultural or (3) cosmopoli$\tan /$ civic/universalist contents, connecting to distinctions within nationalism research of having recourse to arguments of community through jus sanguinis (blood) or jus solis (territory/civic). The source of community and values can thus be diverse, divided between museums of various styles - history, art, technology - into a complex of values for different occasions. Pride can be taken in ethnic origin, collective sacrifice, cultural performances, democratic values, rational thinking and science, to mention just some values carried by museum representations. To perform a symphony, however, they need to be well composed into a whole that is appreciated and acknowledged as a beautiful piece by most of the citizenry.

\section{The concert hall}

National museums within this ideal type work as relatively open and multi-voiced spaces to make communities of values and nations out of conglomerate empires and relatively stable states in times of relative stability. In some of the major states of Europe the Enlightenment-Empire mode of national museums, based on the example of the British Museum, has continued to be relevant because of post-colonial 
influx and the global standing of their nations. Paris and London are good examples of these. Many other empires from the nineteenth century have been transformed into small nations. Early cases were the decolonization of smaller powers such as Sweden and greater ones such as Portuguese and Spanish dominions liberated in the wake of the Napoleonic turmoil, even before museum representations became peak performers in mobilizing citizens for national causes. Remains of these museum complexes complicate the transformation to a viable cultural constitution in later and smaller nation-states. In the midst of the modernization period came the dissolution of the Habsburg and Ottoman multinational empires and of colonial states such as the Netherlands and Belgium. For the latter, a transformation of representation from the empire to a small-state and later multicultural setting has entailed a tough challenge to maintain relevance for the cultural constitutions delivered. It is revealing to compare the performance of the capital of Vienna, the old Habsburg centre, with Budapest, the sister capital and emerging capital of Hungary. In Vienna, art is at the centre of the museum industry, while there is still no better history museum than an oldfashioned Heeresgeschichtliches Museum, while in Budapest the national museum is a celebration of the political making of a nation.

In these examples the political diversity builds up to a more diverse or universalized representation through art, culture and science, characterized by being less centralized and less easy to define in ethnic terms and political direction. This is even more the case if diversity is not politically concerted within a federal structure. Regional diversity resists strong centralized representation in countries such as Italy, the Netherlands, Switzerland and, to some extent, Spain. In former empires, such as Britain, Spain and the Netherlands, there was a need to move beyond one ethnos in order to represent the nation as something that has made art and universal values from the Enlightenment useful.

The debate might be fierce on the nature of an actual museum. A league of metropolitan museums declared themselves Universal Museums in the early twenty-first century, obviously to protect themselves against demands for repatriation based on national cultural context as a stronger claim to legitimate rights. ${ }^{6}$ The truth value of claims are not at stake here, but only observed as one of the relevant components in the building of a legitimate role in the cultural constitution.

The main weakness of this mode of designing a cultural constitution is the multi-layered and open messages of historical narratives and direction. On the strong side is the claim for universal values, most inclusive if appreciated as legitimate, helping to naturalize the state of order and being flexible enough to meet changing contemporary challenges invited by a more open set of cultural representations of community.

The two models above form a pair and a set of options that develops along a continuum from strongly centralized, threatened states or nations in the making with explicit and highly orchestrated representations, a symphony, to long-standing, decentralized and diverse states providing a concert hall for multi-layered negotiations, in which the middle ground was characterized by frequent halforchestrated endeavours, concerts, that set the agenda for the national museums 
performing the cultural constitution as a not only mobilizing but also a dynamic and creative force.

As a net result, the fostering of a long and unified political history or of an ethnic dimension of unity is renounced within cultural constitutions that work as concert halls, at least as the main source of unification, while other means of cultural unity are formulated by diversities, as the role of guardian of universal values and comparative knowledge and art is more useful and less challenging in order not to arouse discontent.

None of these compositions are by their formal aspects or themes good or bad; all of them draw lines of difference. Hence moral judgement should not be made on these grounds but, as the argument goes here, on their capacity to form a viable cultural constitution to frame and productively work through relevant community issues, challenges and dilemmas. Both types orchestrate values, but the ability to act as a relevant constitution with 'the logic of culture' (Bennett 2006) is related to both the legacy of the institutions, the political culture and relevant obstacles in need to be dealt with in the contemporary situation.

A firm base in research and science is a basic prerequisite. True statements stand stronger than false ones in the long run. Still, to evaluate beyond the notion that the public aspects of these institutions should be valued according to their ability to balance values of continuity with those of dynamic change, is the strength and inalienable value of a cultural constitution. The symphony model optimizes the orchestration, is more explicit and potentially more mobilizing for a political project, but also runs a higher risk of reification over time, opposition and exclusion of forces and groups that are not comfortable with the cultural constitution promoted. Italy or Belgium might benefit from more actions within this model to heal the distrust within the nation. Eastern Europe might, on the contrary, benefit from inviting elements of the concert hall to deal with the complex recent history and the strong legacy of Marxist symphonies. The point is not to give the best advice here, which would need a much more thorough analysis, but rather to emphasize the possibility for the cultural institutions themselves to develop, explore and investigate possible roads to raise the relevance and power of the cultural constitution in order to deal with contemporary issues in need of cultural negotiations.

A loss of relevance with reference to trajectories can be read into the inability in some countries to attract financing and/or visitors during certain periods of time. The rather weak development in many Eastern European countries after the First World War is a case in which old structures did not meet the demands of the modern industrial and technological age with the urgency needed to support their development. Old-style art museums that lived on the traditional ideal of Bildung had difficulties in transforming themselves to suit the desires of the new citizenship, as in the example of Latvia. The inability of national museums to create or to recapture their relevance may, however, be caused by active resistance in ways that make national museums relevant while the forces of support are too weak to lead to successful establishment, as in the case of Italy. 
What is the global reach of these generalizations? To what extent are they specific to European culture? Just one hint of a concern to be brought in is the role of religion (see Bennett, Chapter 3 in this volume). A specific aspect is identified by the Turkish case where an Islamic culture of representation prohibits images representing central values, hence counteracting a centralized, visualized representational narrative at the core of the Western idea of visual representation. In brief, museum representations do not necessarily, or at least not explicitly, follow the national political culture of strong national representation that is visible in other fields of national symbolism. Consequently, the power of the national museum as a Western innovation or a universal tool for nation formation outside its cultural context begs for more analysis.

The complexity of considering intended and unintended actions and various logics outside the horizon of actors remains at the core of museums in forming a flexible yet well-defined form of cultural constitution as a complement to the explicit, formal and political sibling formulated as the fundamental law of each state.

\section{Conclusions}

How can the specific cultural constitutions national museums create in different states be evaluated? How important is this cultural institution compared to the abundance of other cultural representations and the delivery of political hardware ranging from a non-corrupt legal framework to welfare provisions? The relative importance of institutional and popular culture, identity versus functionality, is a classic discussion topic (Smith 2003; Brubaker 1992; Stråth and Sørensen 1997). Is it possible to assess the value of this performance in relation to other contributors to the formation of a modern state? This would be the next step to take; bringing together comparative research on the resilience and power of civil society (Misztal 1996; Inglehart and Welzel 2005; Eklund et al. 2011; Trägårdh 2007), the economic and political performance, and the emerging knowledge about cultural constitutions would also provide new arguments for how to look upon culture as an infrastructure not only for the tourist trade but also for creating a sustainable society, nation and state.

I do not think there is a final answer to these questions. Neither is there a conclusive answer to which is the most efficient of the ideal type modes of cultural constitutions presented above. The more essentialist symphony and more processual concert hall resembles the long-standing discussion on the ideal-typical nationalisms connected to each version as ethnic versus civic or jus sanguinis (right of blood) versus jus soli (territorial citizenship).

High and relevant investments in the cultural constitution cannot build bridges, hospitals and good education alone. Still, the chances of raising these investments are higher with a successful cultural constitution. Eastern Europe is an interesting case to consider. Under Soviet occupation cultural policy was a relative priority (Rindzevičiūtè 2008). An infrastructure of stable institutions was reinforced and secured out of the heritage of earlier liberal/fascist states. Some elements were simply retained or slightly restructured so as to work as a cultural valve of 
republican national pride within Stalinist cultural policy. Others were highly ideological, as Marxist-Leninist historiography of the twentieth century was imposed on them. When the legitimacy of the system was increasingly undermined by economic and military forces, this interplayed with renegotiations within the museum system in many countries. The reinforced structure could then easily be turned back on the Soviet system within the same building and sometimes even the same narrative, merely by changing the roles of villain and heroes. Is this an effective cultural negotiation?

To complicate things, a viable set of negotiations at one moment in time might be completely obsolete if not transformed: decolonialization and globalization, World War II, 1989, the Balkan wars, all present ruptures in need of flexible response not only by arms but more so by cultural institutions otherwise marginalized.

The argument here suggests at least three scenarios of lasting implications of how well cultural and political constitutions interplay, consequences of the variation in the anatomy and working of the cultural constitutions:

1. Political culture of tolerance, creativity and integration. The sanction of immigration laws and attitudes to asylum seekers vary considerably, in accordance with differences in the cultural representation of the national past in the Nordic countries (Aronsson and Gradén 2013). National museums naturalize ethnic, multicultural and universalized ideas of communities, where Sweden differs dramatically in its representation of a non-ethnic national story in the "concert hall' type of cultural institutions of recent decades, while Denmark represents the ideal ethnic symphony type. Both countries perform strongly with a high index of trust, creativity and innovation, hence suggesting that the efficiency of the narrative cannot be assessed out of context. On a global scale, the negotiation of ethnic conflicts in settler nations and post-colonial contexts sets examples for the benchmarking of performances: New Zealand and Canada seem more successful in addressing tensions productively by explicitly framing and bridging cultural representation to political action, than for example the US or France (see Porciani, Chapter 5 in this volume).

2. Trust or distrust between civil society and state. Northern Europe, including most remarkably Germany, has come out much stronger through the current economic crisis than has Southern Europe. The level of trust between civic society and the political system is much higher in nations where important conflicts and differences are worked through by cultural constitutions. Northern Europe presents better examples of that, while most Mediterranean states still struggle to deal productively with difficult recent pasts (Porciani, Chapter 5 in this volume; Aronsson 2011a).

3. Civil war or unification. At the bottom line of failed cultural integration lie dissolution and civil war. 'Norden' was transformed from a cultural battlefield to a unifying asset partly by roles of its cultural institutions. In Europe, civil war broke out in Yugoslavia, where unifying concepts for the working through of traumas were not sufficiently at hand. All states have more or less tensions of these kinds 
to deal with. So far the failure of the UK to deal with the Irish question has not spread to Wales and Scotland, where instead cultural negotiations are intense but perhaps not sufficiently represented in London to be successfully integrated.

I think all these cases are strong arguments for the need of a viable cultural policy and for future comparative research. To be sure, the recipe cannot be written out of context and the question of how open the delivered cultural constitution is to act needs to be developed further. There are many ways to fail, the most common being not to find the way to take on the country's relevant and urgent dilemmas. The EU is another example only slowly and gradually acting on culture as a remedy for a tidal wave of dissolution and democratic deficiencies (Axelsson et al. 2012; Eilertsen and Amundsen 2012).

Success is also relative: the overarching achievement of national museums is to prove cultural continuity over time, providing society and people with a material reference of continuity.

The argument developed here is that there is a decisive cultural component that is indispensable for the long-term construction of a political community, and more demanding for creating and maintaining a society that is both creative and effective. The role, shape, visibility and relative importance of the cultural constitution all change over time and need to be given more attention to understand and deal with change.

The power of the Authorized Heritage Discourse provides a well-structured critical concept rapidly encompassed by critical heritage research, as noted in the introduction to this chapter. It captures the structuring power of politically supported heritage processes, which are often criticized for neglecting other forms of uses of the past for the benefit of already privileged groups. The perspective of a cultural constitution on institutionalized heritage, of which I regard national museums as the most articulated and authorized form, sets another scene for placing and valuing AHD. If alive, relevant and meaningful, it presents ongoing negotiations that can play important roles in mediating between spheres and logics otherwise prone to splendid isolation. It brings together knowledge and politics, tradition and contemporary challenges, dealing with difference and negotiating hegemony.

This argument is, again, placed in the theoretical middle ground of these observations and argues the importance of that middle ground, not only as a theoretical standpoint but for the capacity of cultural institutions to stabilize legitimacy through effective negotiation and facilitating change that is not ephemeral. Formal institutions that carry cultural meaning, which negotiate contradictions, tensions and community, are plentiful and fill the public sphere. Museums present a viable and dense node for these multidimensional and persistent negotiations of long-standing dilemmas.

The conceptualization of cultural constitution has here been probed with the contribution of national museums. National museums act as central elements of cultural constitutions in an international grammar that gives them a role in the circulation and negotiation of relationships between nations. They were born out of the Enlightenment and stimulated by the cultural dimension of national war after 
Napoleon, linking traditional heritage and democratic citizenship. Inspired by and interacting with other modern media, they communicate and transport cultural constitutions across national borders (Bennett, Chapter 3 this volume; Sandberg 2003).

In future research it needs to be considered how other dimensions of highly explicate culture in the public sphere contribute to an active cultural constitution (Berger et al. 2008; De Groot 2009). Religion is the most prominent long-term format for a cultural constitution, which has been supplemented by a secular public sphere in the last few centuries. The roles carried by literature and film are among the forms most prone to deal with difficult issues. Initially of course, a much greater personal contribution is required from an author or, with more collective efforts, from a filmmaker. They can, however, achieve similar roles as canonized representations of shared values in the public culture, complementing museum representations. A possible relationship is to state that the threshold for dealing with difficult contentions as a road to reconciliation is lower in more individually authored forms such as literature, which is successively in need for and developing more collective recognition in institutionalized forms reaching the level of cultural constitution. An inability to reach this level hampers the development of generalized trust between civil society, the nation and the state. The need for and roads to reconciliation, or with Jörn Rüsen, Vergangenheitsbeweltigung, varies with the challenges posed (Rüsen 2002). A relevant constitution is, however, always a potential strong contributor to these processes, to enable the logic of culture to make a difference.

\section{Notes}

1 On each of these perspectives there is a volume in the Eunamus project (www.eunamus. $\mathrm{eu}$ ): Aronsson and Elgenius (2011b). See also Knell et al. (2012), Axelsson et al. (2012), Poulot et al. (2012a and b), Dodd et al. (2012), Bounia et al (2012), Eilertsen and Amundsen (2012).

2 A tendency to move decisions on these matters to the court has appeared in the focus of recent decades on the Holocaust and the denials of genocide (Evans 2000; Cajani 2007).

3 In Switzerland a 'cultural constitution', meaning article 69 of the year 2000, states post factum that the confederation may support cultural actions of national interest, while respecting the cultural and linguistic diversity of the country.

4 Eurosphere, 'Diversity and the European Public Sphere: Towards a Citizens' Europe'.

5 This part builds on the concluding section of Aronsson and Elgenius (2011a).

$6 \mathrm{http} / / /$ icom.museum/fileadmin/user_upload/pdf/ICOM_News/2004-1/ENG/p4_2004-1. pdf (accessed 20 February 2014).

\section{References}

Almond, G.A. and Verba, S. (1965) The Civic Culture: Political Attitudes and Democracy in Five Nations: An Analytical Study, Boston: Little, Brown.

Anderson, B. (1983) Imagined Communities: Reflections on the Origin and Spread of Nationalism, London: Verso.

-(1993) Den föreställda gemenskapen: reflexioner kring nationalismens ursprung och spridning, Göteborg: Daidalos.

Aristoteles (1993) Politiken, Partille: Åström.

Aronsson, P. (2007) 'Reproduktionens värden', in B. Axelsson and J. Fornäs (eds.) Kulturstudier $i$ Sverige, Lund: Studentlitteratur, 309-25. 
(2011a) 'Explaining national museums: exploring comparative approaches to the study of national museums', in S.J. Knell, P. Aronsson and A. Amundsen (eds.) National Museums: New Studies from Around the World, London: Routledge, 29-54.

(2011b) 'The productive dilemmas of history', in H. Ruin and A. Ers (eds.) Rethinking Time: Essays on History, Memory and Representation, Stockholm: Södertörn University, 29-38.

(2012) 'Exhibiting Scandinavian culture: the national museums of Denmark and Sweden', in S. Berger, C. Lorenz and B. Melman (eds.) Popularizing National Pasts: 1800 to the Present, London: Routledge, 169-95.

Aronsson, P. and Bentz, E. (2011) 'National museums in Germany: anchoring competing communities', in P. Aronsson and G. Elgenius (eds.) Building National Museums in Europe 1750-2010, Eunamus Report No 1, Linköping: Linköping University Electronic Press, $327-62$.

Aronsson, P. and Elgenius, G. (2011a) 'Making national museums in Europe - a comparative approach', in P. Aronsson and G. Elgenius (eds.) Building National Museums in Europe 17502010, Eunamus Report No 1, Linköping: Linköping University Electronic Press, 5-20.

- (eds.) (2011b) Building National Museums in Europe 1750-2010, European National Museums: Identity Politics, the Uses of the Past and the European Citizen, Eunamus Report No 1, Linköping: Linköping University Electronic Press.

Aronsson, P. and Gradén, L. (eds.) (2013) Performing Nordic Heritage: Everyday Practices and Institutional Culture, Burlington: Ashgate.

Aronsson, P., Aspers, P., Beckman, L., Erixon, F., Micheletti, M., Möller, G., Strömberg, K. and Uddhammar, E. (2001) Dygder som drivkraft och föredöme, Stockholm: City University Press.

Axelsson, B., Dupont, C. and Kesteloot, C. (eds.) (2012) Entering the Minefields: The Creation of New History Museums in Europe, Conference Proceedings from Eunamus, European National Museums: Identity Politics, the Uses of the Past and the European Citizen, Brussels 25 January, Linköping: Linköping University Electronic Press.

Bäckström, M. (2011) 'Loading guns with patriotic love: Artur Hazelius's attempts at Skansen to remake Swedish society', in S.J. Knell, P. Aronsson and A. Amundsen (eds.) National Museums: New Studies from around the World, London: Routledge, 69-87.

Badica, S. (2008) 'Raising the cross: exorcising Romania's communist past in museums, memorials and monuments', in O. Sarkisova and P. Apor (eds.) Past for the Eyes: East European Representations of Communism in Cinema and Museums after 1989, Budapest and New York: Central European University Press.

Bennett, T. (1995) The Birth of The Museum: History, Theory, Politics, London and New York: Routledge.

-(2006) 'Exhibition, difference and the logic of culture', in I. Karp, Kratz, C.A., Szwaja, L. and Ybarra-Frausto, T. (eds.) Museum Frictions: Public Cultures/Global Transformations, Durham, NC: Duke University Press, 46-69.

Berger, S. (2006) 'National historiographies in transnational perspective: Europe in the nineteenth and twentieth centuries', Storia della Storiografia, (50): 3-26.

Berger, S. and Luckman, T. (1967) The Social Construction of Reality: A Treatise in the Sociology of Knowledge, London: Penguin.

Berger, S., Eriksonas, L. and Mycock, A. (eds.) (2008) Narrating the Nation: Representations in History, Media, and the Arts, New York: Berghahn Books.

Bergvelt, E., Meijers, D.J., Tibbe, L. and van Wezel, E. (2009) Napoleon's Legacy: The Rise of National Museums in Europe 1794-1830, Berlin: G+H Verlag.

Bligaard, M. (2000) 'The image of Denmark: museums as sanctuaries of identity', in J.M. Fladmark (ed.) Heritage and Museums: Shaping National Identity. Papers Presented at The Robert Gordon University Heritage Convention 1999, Shaftesbury: Donhead, xxi, 393.

Bounia, A., Nikiforidou, A., Nikonanou, N. and Dicran Matossian, A. (2012) Voices from the Museum: Survey Research in Europe's National Museums, Eunamus Report No 5, Linköping: Linköping University Electronic Press.

Brubaker, R. (1992) Citizenship and Nationhood in France and Germany, Cambridge, MA: Harvard University Press. 
Cajani, L. (ed.) (2007) History Teaching, Identities and Citizenship, Stoke-on-Trent: Trentham Books.

De Groot, J. (ed.) (2009) Consuming History: Historians and Heritage in Contemporary Popular Culture, London: Routledge.

Delanty, G. (2000) Modernity and Postmodernity: Knowledge, Power and the Self, London: Sage.

Dodd, J., Jones, C., Sawyer, A. and Tseliou, M.-A. (eds.) (2012) Voices from the Museum. Qualitative research conducted in Europe's National Museums, Eunamus Report No 6, Linköping: Linköping University Electronic Press.

Eilertsen, L. and Amundsen, A.B. (eds.) (2012) Museum Policies in Europe 1990-2010. Negotiating Professional and Political Utopia [Electronic resource], Linköping: Linköping University Electronic Press.

Eklund, K., Trägårdh, L. and Henrik, B. (2011) Shared Norms for the New Reality: The Nordic Way / World Economic Forum, Davos 2011, Stockholm: Global Utmaning.

Etzioni, A. (1995) New Communitarian Thinking: Persons, Virtues, Institutions and Communities, Charlottesville, VA: University Press of Virginia.

Evans, R.J. (2000) Till historiens försvar, Stockholm: SNS förl.

Fornäs, J. (2012) Signifying Europe, Bristol: Intellect.

Fukuyama, F. (1992) The End of History and the Last Man, New York: Free Press; Toronto: Maxwell Macmillan Canada.

Hammami, F. (2012) Heritage in Authority-making [Electronic resource]: Appropriating Interventions in Three Socio-Political Contexts, Stockholm: Architecture and the Built Environment, KTH Royal Institute of Technology.

Ho, H.T.T. (2001) 'Remembered realms: Pierre Nora and French national memory', The American Historical Review, 106(3): 906-22.

Hobsbawm, E.J. and Ranger, T.O. (1992) The Invention of Tradition, Cambridge: Cambridge University Press.

Höglund, M. (2012) 'European Union Approaches to Museums 1993-2010', in L. Eilertsen and A.B. Amundsen (eds.) Museum Policies in Europe 1990-2010: Negotiating Professional and Political Utopia [Electronic resource], Linköping: Linköping University Electronic Press, $157-88$.

Horne, J.R. (2002) A Social Laboratory for Modern France: The Musée Social and the Rise of the Welfare State, Durham: Duke University Press.

Hroch, M. (2005) Das Europa der Nationen: Die moderne Nationsbildung in europäischen Vergleich, Göttingen: Vanenhoeck \& Ruprecht.

Inglehart, R. and Welzel, C. (2005) Modernization, Cultural Change, and Democracy: The Human Development Sequence, New York: Cambridge University Press.

Knell, S.J., Aronsson, P. and Bugge Amundsen, A. (eds.) (2011) National Museums: New Studies from Around the World, London: Routledge.

Knell, S., Axelsson, B., Eilertsen, L., Myrivili, E., Porciani, I., Sawyer, A. and Watson, S. (2012) Crossing Borders: Connecting European Identities in Museums and Online, Eunamus Report No 2, Linköping: Linköping University Electronic Press.

Lowenthal, D. (1998) The Heritage Crusade and The Spoils of History, Cambridge and New York: Cambridge University Press.

Manojlović-Pintar, O. and Ignjatović, A. (2011) 'National museums in Serbia: a story of intertwined identities', in P. Aronsson and G. Elgenius (eds.) Building National Museums in Europe 1750-2010, Eunamus Report No 1, Linköping: Linköping University Electronic Press, 779-815.

Message, K. (2006) New Museums and the Making of Culture, Oxford: Berg.

Miller, R. (2012) The Development of European Identity/Identities: Unfinished Business. A Policy Review, Brussels: European Commission, Directorate-General for Research and Innovation, Socio-economic Sciences and Humanities.

Misztal, B.A. (1996) Trust in Modern Societies: The Search for the Bases of Social Order, Oxford: Polity Press.

Möller, G. (2003) Moralens nycklar: en bok om dygder, Skellefteå: Norma. 
Nora, P. and Kritzman, L.D. (eds.) (1996) Realms of Memory: Rethinking the French Past, New York: Columbia University Press.

Österberg, E., Cronberg, M.L. and Stenqvist, C. (eds.) (2012) Dygdernas renässans, Stockholm: Bokförlaget Atlantis.

Post, R.C. (2000) 'Democratic constitutionalism and cultural heterogeneity', Faculty Scholarship Series. Paper 189, http://digitalcommons.law.yale.edu/fss_papers/189.

Poulot, D., Bodenstein, F. and Lanzarote Guiral, J.M. (eds.) (2012a) Great Narratives of the Past [Electronic resource]: Traditions and Revisions in National Museums, Conference Proceedings from Eunamus, European National Museums: Identity Politics, the Uses of the Past and the European Citizen, Paris 28 June-1 July and 25-26 November 2011, Linköping: Linköping University Electronic Press.

Poulot, D., Guiral, J.M.L. and Bodenstein, F. (eds.) (2012b) National Museums and the Negotiation of Difficult Pasts, Eunamus Report No 8, Linköping: Linköping University Electronic Press.

Putnam, R. D., Leonardi, R. and Nanetti, R.Y. (1992) Making Democracy Work: Civic Traditions in Modern Italy, Princeton, NJ: Princeton University Press.

Rentzhog, S. (2007) Open Air Museums: The History and Future of a Visionary Idea, Stockholm, Östersund: Carlsson; Jamtli förlag.

Rindzevičiūtè, E. (2008) Constructing Soviet Cultural Policy: Cybernetics and Governance in Lithuania after World War II, Linköping: Department for Studies of Social Change and Culture, Linköping University.

- (2010) 'Soviet Lithuanians, amber and the "New Balts" historical narratives of national and regional identities in Lithuanian museums, 1940-2009', Culture Unbound. Journal of Current Cultural Research, 2: 665-94.

Rothstein, B. (2000) 'Trust, social dilemmas and collective memories', Journal of Theoretical Politics, 12(4): 477-501.

Rüsen, J. (2002) Geschichte im Kulturprozess, Köln, Weimar and Wien: Böhlau.

Sandberg, M.B. (2003) Living Pictures, Missing Persons: Mannequins, Museums and Modernity, Princeton, NJ: Princeton University Press.

Sarkisova, O. and Apor, P. (eds.) (2008) Past for the Eyes: East European Representations of Communism in Cinema and Museums after 1989, Budapest and New York: Central European University Press.

Sartori, G. (1994) Comparative Constitutional Engineering. An Inquiry into Structures, Incentives and Outcomes, Basingstoke and New York: Macmillan and New York University Press.

Sennett, R. (1998) The Corrosion of Character: The Personal Consequences of Work in the New Capitalism, New York: W.W. Norton.

Smith, A.D. (2001) Nationalism: Theory, Ideology, History, Cambridge: Polity.

Smith, L. (2006) Uses of Heritage, New York: Routledge.

Smith, L., Cubitt, G., Wilson, R. and Fouseki, K. (eds.) (2011) Representing Enslavement and Abolition in Museums: Ambiguous Engagements, New York: Routledge.

Smith, R.M. (2003) Stories of Peoplehood: The Politics and Morals of Political Membership, Cambridge: Cambridge University Press.

Stråth, B. and Sørensen, Ø. (eds.) (1997) The Cultural Construction of Norden, Oslo: Scandinavian University Press.

Szreter, S. (2002) 'The state of social capital: bringing back in power in politics and history', Theory and Society, 31: 573-621.

Taylor, C., Appiah, K.A. and Gutmann, A. (1995) Det mångkulturella samhället och erkännandets politik, Göteborg: Daidalos.

Trigger, B. G. (1989) A History of Archaeological Thought, Cambridge: Cambridge University Press.

Trägårdh, L. (ed.) (2007) State and Civil Society in Northern Europe: The Swedish Model Reconsidered, New York and Oxford: Berghahn Books. 


\section{INDEX}

Academy of Painting and Sculpture, Brussels 92

Acropolis 104

Act for the Preservation and Enhancement of Multiculturalism in Canada (1988) 123

African Art Museum, Belgrade 109

Agence France Museum 52

Ájtte, Mountain and Sámi Museum, Sweden 153

AKP 183

Alberto, Carlo 135

'Albertopolis,' London 105

Algeria 49, 50

Almond, G.A. 174

Alte Nationalgalerie, Berlin 19, 20

Alte Pinakothek, Munich 103, 104

Altes Museum, Berlin 103

'ambassador objects' 94

amber 72

Amber Museum, Palanga 72

American Revolution 154

Amgueddfa Genedlaethol Cymru 24-25

Amsterdam 105, 109

Anderson, Benedict 66, 67, 73, 77, 84 n1, 145,148

Ang, Ien 79, 80

anthropology 70, 136

Antiquarian Commission, Iceland 152, 157

antiquarians 21

antiquities $14-15$

Aragon Front 129

Archaeological Museum, Sofia 44-45 archaeological museums 13, 15, 21, 38, $42-43,92,112$

archaeology 70, 72, 156, 182, 184, 186

architecture 57, 76

Aristotle 173

Army Museum (Heeresgeschichtliches Museum), Vienna 22

art 136; defined 94; interpretation of 95;

legitimacy 95-96; ownership of 93-94;

see also art museums

art galleries 77-78, 79; exhibitions 94

Art Gallery of New South Wales, Buddha:

Radiant Awakening (2001) 79

art-historical representation 182-83

art history 16, 36

Art History Museum, Vienna 22

art museums 16, 33, 38-43, 80, 89-113,

$161,179,184-85$; artists 98-101, 112;

cultural (re)production 110-12; function

113; investments 108; legacy of civil society 95-97; literature dedicated to 108; museum pieces 97-102; ownership of art 93-94; portraits 98; regional artworks 98; settings 102-6; subject matter 112; timely works 101-2; uses of 106-12, 112

Art School, Lithuania 100

art societies 95

Arthur, Chris 84 n6

ascetic movements 75

Assembly of First Nations (Canada) 123

Association of German Engineers 17

atrocities, past, walking through 187 
Au pays de la mer exhibition 98

Aufseß, Hans von 14-15

Auschwitz exhibition 54

Ausgleich (1867) 18

Australia 70, 78-79, 123, 171

Australian Aboriginal and Torres State Island peoples 83, 123

Australian Museum, Sydney 70

Australian Racial Discrimination Act 123

Austria 135, 151, 155; art museum settings 105; heritage of Middle Ages 39; history museums 129-30; landscape 125; Ostarrichi Urkunde 130; post 1918 35-36; Waldheim affair 130

Austrian Empire 22, 155

Austrian Republic 130

Austro-Hungarian Empire 36, 37, 155, 156-57; see also Austria; Hungary

Authorized Heritage Discourse (AHD) 168, 195

avant-garde 90

Baker, Keith 76-77

Balkans 44-45; see also individual nations

Ban, Shigeru 106

Bankside Power Station 103

'barbarism' museum, Cyprus 127

Barberis, Walter 135

Basque region 72, 105-6, 120

Basso Peressut, Luca 122

Bauhaus 104

Bavaria 19, 184

Bavarian National Museum, Munich 19

Bazar du genre exhibition 136

Beaubourg Centre, Paris 105

beauty, common ideal of 89

Belgian Congo see Congo

Belgium 151; art museums 99-100; art ownership 92; colonial museums 49, 52; colonialism 70; cultural constitution 191, 192; 'difficult heritage' 72-73; history museums 130-31; history of civilization 159; imperialism 21-22, 155; national/ transnational intersections 69 ; as new nation state 18-19

Bellevue Palace, Brussels 130-31

Bellini, Mario 106

BELvue, Brussels 130-31, 135

Bénédite, Léonce 98

Benjamin, Walter 112

Bennett, Tony 18, 136, 177, 178

Berlin 171

Berlin collection 184

Berlin Secession 96

Berlin Wall 47
Berlusconi, Silvio 131

Bessarabia 37

biblical hermeneutics 70

Bildung 72, 75-76, 192

Bilgi University 179

biopolitical power 75,83

'Bizot Group' 94

Black Canadians 125

Blackwoods Magazine 104

Blair, Tony 81

Blais, Jean-Marc 137 n2

blockbuster exhibitions 94

Blut 122, 125

Bode, Wilhelm 95, 108

Boden 122, 125, 126

Bonaparte, Joseph 92

Book of Flatey 158

borders 120-21, 124-25

Bosnia-Herzegovina 69, 84 n4, 130, 152, 156-57

Bosschaert, Ambrosius 92

Boullée, Étienne Louis 103

boundaries 146, 148

Bourdieu, Pierre 82; The Love of Art 109

Brazil 154

British Empire 154

British Isles 154; see also individual nations

British Museum, London 16, 18, 21, 28, 51, 70, 73, 92, 107, 151, 154, 190-91

Britishness (British Identity) 71, 73, 154

Brittany, folk life 98

Broel-Plater, Władysław, Count 97

Brown, Wendy 67

Bruno, Giordano, Tour de France par deux enfants 126

Budapest, cultural constitution 191

Buddha: Radiant Awakening exhibition (2001) 79

Bulgaria 19, 26, 44, 46, 69, 130, 153, 189

Byzantine and Christian Museum, Greece 14,42

Cabinet of Natural History, Madrid 23

Caillebotte, Gustave 96

Calgary 125

Cambrian Archaeological Association 24

Canada 171, 173, 188; Chinese immigrants and coolies 125; cultural constitution 194; first nations 123; history museums 123-25; multiculturalism 123

Canadian Museum of Civilizations, Ottowa 124

Canadian Museum of History 136-37

Carandini, Andrea 132-33

Carniola 155 
Cassou, Jean 101

catalogue publications 98-99

Catalonia 120, 125

Catholic Church/Catholicism 67, 75, 76, $81,129,132$

Ceausescu, Nicolae 46

Centre Pompidou, Paris 102, 103

Centre Pompidou, Shanghai 52

Cézanne, Paul 96

Chaptal, Jean-Antoine Claude 92

Charle, Christophe 129

Charles, Prince of Wales 105

China 188; Japanese conflict 187

Chinese immigrants and coolies 125

Chipperfield, David 105

Christianity 67, 74, 79, 80, 82; see also Catholic Church/Catholicism; Church of England

Church of England 78

church, the, properties 92

Cité de l'histoire de l'immigration 136-37

Cité Nationale de l'Immigration, Paris 129

citizenship 121, 148, 192

civic approaches 18, 19, 131, 176, 190, 193

civil society: legacy of 95-97; and the state

8, 19, 194, 196

civilization 37, 38, 39, 48, 51

Clark, Timothy J. 94

Codex Regius 158

Cold War 33, 47, 55-56, 59, 109

Cole, Henry 77-78, 110, 111

collections, formation of 121

Colley, L., Britons: Forging the Nation 154

Cologne 184

colonial art museums 78-79

colonial museums 48-53, 59, 184; see also empires/imperialism; ethnology

colonialism 21, 34, 70-71, 174

colonized peoples, marginalization of 75

Columbian Spanish World Exhibition 50-51

Columbus, Christopher 23, 50

Commission of Antiquities, Norway 151, 157

communication infrastructure 78

communism 54, 55, 189

Communist Party, Romania 45-46

concept of diagram (Deleuze) 66

concert hall model 8, 190-93, 194

confiscation 92

conflict management 185-88

Congo 21, 49-50, 70

constructivist approach 167, 169, 178

Copenhagen 184

Cornelius, Peter 104

cosmopolitanism 6, 106, 111, 185, 190

Cottet, Charles 98
Council of British Druids 81

Council of Europe 84 n4

Creation Museums 80

creationism 80

Croatia 54, 152, 159

Croce, Benedetto 133

Crystal Palace, London 102

Cuba 23

cultural approaches 33

cultural constitutions (Aronsson) 3, 7-8, 168, 172, 174, 175-77, 176; defining national museums 171-72; evaluating 193-96; format of 178; ideal types 189-93; knowledge management and great narratives 182-88; museum works 177-82; negotiating 169-70; powerful stories and failed relevance 188-93; tolerance, creativity and integration 194; trust or distrust, civil society and state 8 , 19, 194, 196

cultural difference/diversity 81, 83, 183, 185

cultural history 182-83

cultural unity 185

culture 148-49, 155, 183; material 57; and politics 177-78; Sovietizing 56; see also art museums

culture transfer 26-27

curators: as artists 90; professionalism 108

Cyprus 102, 188; 'barbarism' museum 127; Greek Cypriots 72, 156; Turkish Cypriots 72, 156

Cyprus National Museum 153, 156

Czech Republic 151

Czechoslovakia 183, 189; post 1918 35-36, 37

'Czechoslovakist' Museum, Bratislava 45

Dacian peoples 46

Danish Folk Museum 68

Danish Popular History Museum 27

de Gaulle, General 97

de Goncourt, Edmond 96

De Luna, Giovanni 135

de Madrazo, José 90

de Quincy, Quatremère, Letters to Miranda 92 'degenerate works' 93

Deleuze, Gilles 66

Denmark 14, 23, 151, 154, 157; art ownership 93; cultural constitution 190, 194; history of civilization 159; national flag 162; national/transnational intersections 67,68 ; royal collections 68 ; transnationalism 27

Denon, Dominique-Vivant 90

Deutsche Museum, Munich 17, 179, 184 
'difficult heritage' 72-73

Disziplinierung 120

division of labour 173, 175-76, 177, 182,183

division of powers $175-76$

documentation centres 53

Dresden Gemäldegalerie 103

Duncan, Carol 109

Durand, Jean-Nicolas-Louis 103

Dutch National History Museum, Amsterdam 127

Eastern Europe 120, 182, 189; cultural constitution 192, 193-94; see also individual nations

École des Beaux-Arts, France 103

École du Louvre 90

École Polytechnique 103

education 179, 180, 192; state-led 148-49

El Escorial 23

Elgin enterprise 92

Elgin Marbles see Parthenon Marbles

elites 4-5, 17, 24, 28, 33, 34, 36-40, 41, 42, 43-45, 56, 57, 59, 102, 108, 113, 132, $145,146,155,156,158,179$

empires/imperialism 13-14, 16-17, 21-23, $67,162,171,184,191$; and ethnography 43; regional diversity 22

England: art museum settings 102-3, 104; cultural constitution 190; 'difficult heritage' 72-73; folk disciplines 72; national art 100; national flag 162

Engler, Steven 82

Enlightenment 109, 112, 154, 155, $168-69,170$

Enlightenment-Empire model 190

'ephemeral museum' 94

Erdogan, Recep Tayyip 183

essentialism 123

Estonia 69, 152; art museums 90; ethnic multiculturalism 56-57; ethnography museums 44; history of civilization 159; memorial museums 54; national art 100 , 101; national/transnational intersections 68; socialist patriotism 47 ; transnationalism 27, $84 \mathrm{n} 4$

'Estonia: Land, People, Culture' exhibition 57

Estonian History Museum, Tallin 57

Estonian National Museum, Tartu 27, 57, 152 ethnic assimilation 188

ethnic multiculturalism 55-58, 59

ethnic narratives 189

ethnographic approach 43, 112

ethnography museums $33,38-45,48,71$, 72, 106-7, 182, 190
Étonnants Voyageurs 128

Eunamus reports 68, 69, 71, 73, 84 n4, 121, 130, 131, 189, $197 \mathrm{n} 1$

Eunamus research programme 3, 180

European Commission 3

European house of History, Brussels 188

The European National Museums: Identity Politics, the Uses of the Past and the European Citizen (Eunamus) 3, 170

European Union 173, 176, 183, 185, 186, 195

evolutionary theories 80

exclusions 148

'exhibitionary complex' 77

expository guides 99

fascism 42

Filippetti, Aurélie 129

film, as cultural constitution 196

Finland 152, 154, 157; archaeologicalhistorical narrative 40; cultural constitution 190; ethnography museums 44; national/transnational intersections 68; as new nation state 18; post 1918 36; transnationalism 27, 73

Finnish Art Society 152, 157

Finnish Museum of Natural History, Helsinki 18, 40

Finnish National Gallery 18, 40

Finno-Ugric (Sámi) peoples see Sámi people First World War 59, 135; aftermath 33, 34-38

Flemish School 99-100

Florence 93, 94

folk costumes 186

folk culture $38,41,43,112,186-87$

folk history museums 15-16, 23, 72

folk tales 100

folklore see folk culture

Fort Thüngen 105

Fortuin, Pym 127

Foucault, Michel 5, 66, 67, 73-74, 167

framing consensus 187

France 15, 134, 151, 154, 170, 182, 188; art museums 90, 98, 99, 102, 105, 106, 109; art ownership 92, 93; colonial museums 48-49, 52, 71; colonialism 70; cultural constitution 190, 194; 'difficult heritage' 72-73; ethnic multiculturalism 57; Grand débat sur l'identité nationale 128; history of civilization 159; imperialism 21, 155; landscape 126; modern art 101, 102; national flag 160; national/transnational intersections 67; natural history museums 74, 128; pastoral power 76; Popular 
Front 70; post 1918 35; regional

museums 25-26, 136-37;

transnationalism 26

Franco, Francisco 49

Franco-Prussian war 93

Frederick Wilhelm IV 19

French revolution 28, 92, 132, 134, 135, 146, 154, 155

Friedrich Wilhelm III, King of Prussia 103

Führermuseum, Linz 103

fundamentalism 80,82

future, new, distancing for 187

Galleria Nazionale d'Arte Moderna, Rome 101

Gallery of the Mnam-Pompidou 94

Galli della Loggia, Ernesto 132-33

Garibaldi, Giuseppe 132

GDR 180; socialist patriotism 45, 46, 47

Gehry, Frank 105-6

gender 127

genocide, denials of $197 \mathrm{n} 2$

genocide museums 184

geology 72

George III, King 16

Germania 19

Germanisches Nationalmuseum,

Nuremberg 39, 44, 104, 152, 171

Germany 14-15, 47, 134, 152, 170-71, 180, 182, 184, 188; art museum settings 105; art museums 90, 96, 108; Bildung 72, 75-76, 192; colonial museums 52-53; colonialism 70; cultural constitution 194; ethnography museums 44; Hellenic culture 72; heritage of Middle Ages 39; Jewish and Romany populations 71; Kultur 48; landscape 126; national flag 160; national/transnational intersections 67; as new nation state 19 ; pastoral power $75-76$

Gesamtkunstwerk 104

Getty Museum of Los Angeles 94

Ghent Altar 93

Ghica, Mihalache 20, 37

Giotto celebration, Florence 94

global history 34, 51

Global Louvre 106

globalization 180

Goa, David 82

Gosden, Chris 84 n3

Goupil merchant house, Paris 111

governance 120

governmental power 73-79, 83

governmentality $18,75,83,181$
Grand Duke Jean Museum of Modern Art,

Luxembourg City 105

Grand Louvre, Paris 105

Great Britain 73, 151, 188; 1707 Act of Union 154; art museums 109-10; colonial museums 51; colonialism 70 , 84 n5; cultural constitution 191; history of civilization 159; imperialism 154-55; national flag 160; national/transnational intersections 67; post 1918 35; religious affiliation 80; religious tolerance 79; see also individual nations

Great Exhibition (1851) 102

Great Patriotic War 33

Great War Museum, Germany 39

Greater France 71

Greece 14, 153, 154, 179; archaeological heritage 42; art museum settings 104; Byzantine heritage 156; cultural constitution 190; history of civilization 160; nationalism 156; statehood 72

Greece, ancient 17, 42, 72, 75, 156, 158, 182, 184

Greek Cypriots 72, 156

Greenblatt, Stephen 107

Greenland 68

Griaule, Marcel 71

Gripsholm Palace, Mariefred 98

Guadet, Julien 103

Guggenheim Museum, Bilbao 105-6

Gulbenkian Foundation 97

Gulbenkian, Lisbon 179

Gull, Gustav 104

Habsburg Empire 18, 22, 67, 191

Hadid, Zaha 101

Hage, Ghassan 81, 82

Haider, Jörg 130

Hartog, F. 120

Haus der Deutschen Kunst 93

Hazelius, Arthur 27, 43, 179

Heeresgeschichtliches Museum, Vienna 191

Hegel, Georg 79

Heraclitus 170

heritage 33-34, 59, 119, 136, 168, 171, 182-83; difficult 72-73; Middle Ages 39; spiritual 57; see also art museums

Hermitage Museum, Amsterdam 179

Hermitage Museum, St Petersburg 69

heterogeneity 173

Hetherington, Kevin 66

historical material, as recyclable 162-63

'historical memory' 129

Historical Museum, Athens 182 
historicity 119

history museums $15,33,38-43,129-35$, $161,179,182$; autobiography of the nation 121; citizenship 121; presentism 119-22, 136; and scholarship 122; the subaltern and the colonized 122-25

Hitler, Adolf 103

Hobsbawm, Eric 145, 147

Hollande, François 129

Holocaust 33, 34, 47, 71, 182, 197 n2

Holocaust museums/exhibition 54, 55, 72, 184, 188

Holstein 68

Holy Roman Empire 74, 170

home, politics of 145, 158

Hong Kong Museum 126

Honourable Society of Cymmodorion 24

Hotel de Cluny, Paris 15

House of Terror Museum, Budapest 53-54, 179

Hoyle, W.E. 27

Hultén, Pontus 102

Humboldt University, Berlin 179

Hungarian National Museum, Budapest 15, 16, 18, 22, 35, 36, 39, 151, 171, 191;

'The History of Hungary Since the Conquest' 46

Hungary 15-16, 134, 151, 188, 189; cultural constitution 190, 191; heritage of Middle Ages 39; history of civilization 159; imperialism 18, 22; Magyar culture 183; memorial museums 53-54; as new nation state 18; post 1918 35-36, 37; socialist patriotism 46

Hurt, Jakob 27

Iceland 68, 98, 100, 152, 157, 158

ICOM 84 n 4

identity politics $162-63$

'imaginary museums' (Malraux) 111

imagined community 145, 146, 148

immigration laws 194

immigration museums 129

Imperial War Museum, London 35

Impressionists 96

Inari Sámi Museum (Siida Sámi Museum), Finland 153

India 70

indigenous peoples 71,81

Indo-China 70

industrial museums 17

Inglis, Alison 78

Institution for the Encouragement of Fine

Arts, Edinburgh 95

institutional theory 174
International Council on Museums $84 \mathrm{n} 2$

International Library of Sociology and

Social Reconstruction of Karl

Mannheim 113

inventory catalogues 99

Ireland 43, 73, 153

Irish question 195

Irish Troubles 187

Islam 67, 72, 74, 76, 83; see also Muslims

Israel, memorial museums 54

Istanbul Modern Museum of Art 102

Istanbul Museum of Painting and Sculpture 38

Italy $17,151,182,188 ; 150$ th jubilee (2011)

131-35; archaeological heritage 42;

brigantaggio 132; church-state divide 131 , 132; cultural and ethnic diversity $84 \mathrm{n} 4$; cultural constitution 191, 192; history museums 131-35; Jacobin Republics 132, 134; landscape 126; Masonic movements 135; modern art 101; national flag 160; as new nation state 20; pastoral power 76; Resistance as the Second Risorgimento 134; Risorgimento 132, 135; the Thousand 132

Japan: Chinese conflict 187; nature 126 Jasenovac memorial museum, Croatia 54 Jeanron, Philippe-August 90

Jevons, W. Stanley 109

Jews 47, 71, 83, 129-30

John Paul II, pope 129

Jones, Owen 104

Jónsson, Ásgrímur 100

Joseph II, emperor 92

Joyce, Patrick 78

Judaic-Christian tradition 79

Judaism 74; see also Jews

Julius Caesar 21

Justi 108

Kaiser Friedrich-Museums-Verein, Berlin 19

Kaplan, Flora 18

King Baudouin Foundation 130

knowledge management 182-88

Kulturforum, Berlin 103

Kümmel Report 93-94

KUMU Art Museum, Estonia 101

Kun, Béla 36

Kunsthistorisches Museum, Vienna 35, 104

Kunstpolitik 93

Kunstvereins 95

Kurds 188

Landesmuseen 22

landscape $17-18,57,125-26$ 
landscape gardening 16

Lanzi, Luigi, Pictorial History of Lower Italy 99

L'Art décoratif 98

Latin American Revolution 154

Latour, Bruno 112, 167

Latvia 153; art and culture 40-41; cultural constitution 192; ethnic multiculturalism 56-57; ethnography museums 44; memorial museums 54;

transnationalism $84 \mathrm{n} 4$

Latvian Ethnography Museum, Riga 44

Latvian National Museum of Art, Riga 40

Lauenburg 68

Le Bris, Michel 128

Le Monde 129

'leading for Europe' project 94

League of Nations International Commission for Intellectual Cooperation $84 \mathrm{n} 2$

Lega 131, 132

Lejeune, Philippe 121

Lemoine report 128-29

Leopold II, King 21

Leopold museum, Vienna 105

Levra, Umberto 134

Lisbon 97

literature, as cultural constitution 196

Lithuania 69, 153, 189; art and culture 41; Constitutive Assembly 100; ethnic multiculturalism 56-57; memorial museums 54; national art 100-101; national/transnational intersections 69; post 1918 36; socialist patriotism 47; transnationalism $84 \mathrm{n} 4$

Lithuanian Ethnographic Museum of Everyday Life, near Kaunas 57

Liverpool 57

logic of culture (Bennett) 177, 192, 196

London: art fields 78-79; cultural constitution 191, 195

looting 92, 93-94

loss and guilt 4, 33, 59

Louis II of Hungary 36

Louis-Philippe, King 103

Louvre Abu Dhabi 52, 106

Louvre, Paris see Musée du Louvre, Paris

Ludwig I, King 103

Luxembourg 100, 152

Macdonald, Sharon 76

Magyar culture 183; see also Hungary

Mahr, Adolf 43

Maison de l'Histoire de France, Paris 128

Maleuvre, Didier 84 n6

Malraux, André 111
Malta 152

Manzoni, Alessandro, The Betrothed 126

Maori people 187

Marijnissen, Jan 127-28

Marseille 136

Marxism 180, 189, 192

Mazzini, Giuseppe 132

McGregor, Neil 107

Mechel, Christian von 99

Melloni, Alberto 133

memorial museums 53-55, 59

memory, materialization of 119

Mezzadra, S. 120

Middle Ages, heritage 39

migration 34

military collections 17, 35, 129-30, 179, 183-84

military expansion 21

Military Museum, Istanbul 17

M.K. Ciurlionis National Museum of Art 100-101, 153

modern art 101, 185

Moderna Museet, Stockholm 102, 184

monarchy 20-21; see also royal collections

Morocco, Spanish Sahara 49

Morse, Samuel 110

Mourey, Gabriel 98

MuCEM 136

multicultural ethnicity 55-58

multiculturalism $34,55-58,59,82,83,123$, 127, 188, 190

Munch, Edvard 100

Munich 171, 184

Munich Glyptothek 103, 184

Musée de Cluny, Paris 104

Musée de la France d'Outre-mer, Paris 48-49

Musée de l'Armée, Paris 35

Musée de St. Germain-en-Laye, France 21, 27

Musée des Monuments Français 15, 28

Musée d'Orsay, Paris 98, 101, 111-12

Musée du Congo Belge, Tervuren 21-22, $49,52,70$

Musée du Louvre, Lens 106

Musée du Louvre, Paris 21, 25, 28, 69, 90 , 92, 93, 96, 98, 99, 101, 102, 103, 105, 106, 110, 111, 151, 155, 182

Musée du Luxembourg, Paris 96, 98, 99

Musée Ethnographie du Trocadéro, Paris 25-26

Musée Napoleon, Paris 21

Musée National d'Art Moderne, Paris 101, 103, 106

Musée National des Beaux-arts d'Alger, Algiers 49 
Musée Royal de l'Afrique Centrale, Tervuren 21-22

Musée Royal de l'Armée, Tervuren 21, 22

Musées de l'Homme, Hanoi 70

Musées Royaux d'Art et l'Histoire, Brussels 19

Musées Royaux des Beaux-Arts de Belgique, Brussels 69, 151, 155

Musei Nationale, Naples 20

Museo Borbonico, Naples 20

Museo Centro de Arte Reina Sofia, Madrid 93

Museo de America, Madrid 49

Museo de Arte Contemporáneo, Toledo 101

Museo del Risorgimento, Torino 133-34, 135

Museo della Civiltà Romana, Rome 42

Museo dell'Impero Romano, Rome 42

Museo Industriale Italiano, Torino 17

Museo Josefino, Madrid 92

Museo Nacionale del Prado, Madrid 28, 90 , 93, 105, 151

Museo Nationale, Naples 93

museum architecture 16, 17, 27, 84 n5

Museum Boymans, Rotterdam 111

Museum für Deutsche Geschichte, Berlin 47

Museum-Library of the Overseas, Spain 23

museum locations 27

Museum of African Art, Belgrade 50

Museum of Contemporary Art, Belgrade 102

Museum of Decorative Arts and Designs

(Kunstindustrimusee), Oslo 23

Museum of Ethnography, Sofia 44

Museum of Fine Arts, Warsaw 36, 152

Museum of Genocide Victims, Vilnius 54

Museum of Manufactures see Victoria and

Albert Museum

Museum of National History, Italy 132-33

Museum of Natural History, Denmark 68

Museum of Natural History, London 80, 84 n5

Museum of Natural History, New York 80

Museum of Occupation, Riga 54

Museum of Occupation, Tallin 54

Museum of the Spanish Army, Toledo 129

museum security 93

museum studies 122

museum works 177-82; negotiating a vision

178-80; negotiating politics through

culture 177-78

Museuminsel, Berlin 19, 39, 105, 182

museums: as agents of change 177;

cathedrals of the nation 136; closure of

156-57; symbols of land ownership 124

museums of atrocities 53-55

museums of technology 184
MuseumsQuartier, Vienna 105

Muslims 80, 81, 82; see also Islam

Mussolini, Benito 42

mystical movements 75

Naples, art ownership 93

Napoleon Bonaparte, Roman collections 72

Napoleon III 21, 27

Napoleonic Empire 67, 92

Napoleonic Wars 154, 170

Napolitano, Giorgio 131

Naroden Muzei (People's Museum), Sofia 19, 26

nation-building: actors $151-53,158-60$; comparative study 149-61; and national museums establishment 159; national symbols markers of 146-48, 160-61; new nation states 18-21; periods of 147 ; temporal reach $151-53,158-60$

national anthems 160, 161-62

National Archaeological Museum, Athens 14, 153, 156

National Archaeological Museum, Sofia 46, 153

'national art' 99-100

National Congress of American Indians, United States 123

national days 146, 147, 160, 162; dating 161-62; groupings 161

national flags 147, 160, 162; dating 161-62; flag types 161

National Gallery, Berlin 96

National Gallery, London 69, 94, 97, 107, 110

National Gallery (Nationalgalleriet), Oslo 23

National Gallery of Denmark, Copenhagen 68

National Gallery, Reykjavík 98

National History Museum of Bulgaria, Sofia 46

National History Museum of Latvia, Riga 153

National History Museum of Romania, Bucharest 46

National Maritime Museum, London 51, 52

national master narratives $13,20,161$; and knowledge management 182-88; plurality 26, 29, 119-20, 136

National Museum of Algeria, Algiers 49

National Museum of Ancient Art, Lisbon 152

National Museum of Antiquities, Bucharest 20

National Museum of Antiquities, Edinburgh 152

National Museum of Art, Architecture and Design, Norway 101 
National Museum of Bosnia-Herzegovina, Belgrade 152, 156-57

National Museum of Croatia, Zagreb 152

National Museum of Czechoslovakia, Prague 37

National Museum of Denmark, Copenhagen 68, 151, 157

National Museum of Finland, Helsinki 13, 18, 36, 40

National Museum of Hungary see Hungarian National Museum

National Museum of Ireland, Archaeology, Dublin 43, 153

National Museum of Natural History, Luxembourg City 152

National Museum of Poland, Cracow 36

National Museum of Poland, Warsaw 40, 152

National Museum of Romania, Bucharest 45,152

National Museum of Scotland, Edinburgh 125

National Museum of Serbia, Belgrade 41, 152, 157

National Museum of Slovenia, Ljubljana $152,155,156$

National Museum of the American Indian, Washington D.C. 123, 124, 187

National Museum of the Czech Republic, Prague 151

National Museum of Wales, Cardiff 24-25, 27, 37, 153

National Museum of Yugoslavia, Belgrade 41 national museums: architecture 181-82; comparative study of nation building 149-61; and constitutions 170-76; defining 171-72; establishment 162; fading into insignificance 188; and high culture 148-49; inauguration: pivotal dates 150-58, 151-53; locations 181; meaning of 177 ; as mobilizing 188; periods of nation-building 147; as reactive 188; as stabilizing 188 ; symbolic regimes approach 146, 160-63; timeline 150

National Museums Liverpool 57

National Museums Northern Ireland 153

National Portrait Gallery, London 98

National Portrait Gallery, Mariefred, Sweden 98, 151, 157

national states, creation of 2

national symbols 156, 157; markers of nationbuilding (Elgenius) 146-48, 160-61

national/transnational intersections $67-73$ national values $2-3$

Nationale Konst-Gallerij, Amsterdam 151; see also Rijksmuseum, Amsterdam nationalism 33, 148, 155, 157, 158, 172; monarchical 20-21

nations: as communities 67,146 ; defined by perceived or claimed past 159; as imagined community 67 ; layered with symbolism 161-62; represented by women 127; rival ambitions 148, 149, 154, 162; role of 2

Natural History Museum, London 18

Natural History Museum of Finland; see Finnish Museum of Natural History, Helsinki

Natural History Museum, Vienna 22, 182

natural history museums $17-18,71,74$

nature 125-26

Naturhistorisches Museum, Vienna 35, 104

Nazi regime 39, 42, 43, 93, 187

Nazism 54, 130

Neilson, B. 120

neo-Marxism 167

Nepveu, Eugène-Charles-Fréderic 103

Netherlands 151, 188; art and culture 41; art museum settings 105; art museums 109; colonial museums 48, 51-52; cultural constitution 191; heritage of Middle Ages 39; imperialism 23; multiculturalism 127; national flag 160; national/transnational intersections 67 ; natural history museums $127-28$

networks 136

Neue Museum, Berlin 104

Neue Staatsgalerie, Munich 96

Neues Museum, Berlin 105, 126, 182

New Hermitage, St Petersburg 103;

'Corner Painting Room' 110

new-media museums 54

New South Wales 123

New Zealand 70, 171, 187; cultural constitution 194

Next Stop Freedom Exhibition 125

Nicholas I, emperor 103

Nishizawa, Ryue 106

Nora, Pierre, Lieux de Mémoire 119, 121, 126

Norden 2, 194

Nordic Ancient Museum, Denmark 14

Nordic Museum, Oslo 27

Nordiska Museet, Stockholm 43-44, 179

North Korea 188

Northern Ireland 153, 173; history of civilization 159

Norway 68, 151, 154, 157; archaeological heritage 43; art museums 99; ethnography museums 43-44; history of civilization 160; national art 100; 
nationalism 157; regional museums 25; as stateless nation 23-24; transnationalism 27,73

Norwegian Folk Museum, Oslo 23

Nouvel, Jean 106

Nuremberg Museum 14-15

Nyerup, Rasmus 14, 170

OECD 171

Office Internationale des Musées (OMI) 69, $84 \mathrm{n} 2$

Officina Grandi Riparazioni, Torino 133, 134-35

Ojakangas, Mika 75

Olsen, Bernard 27

'Olympic museum', proposed 99

O’Neill, M. 124

open-air folk museums 16

Open Air Museum, Tallin 47

open-air museums 57

open museums 136

orchestrated diversity 186

Osterhammel, Jürgen 13

Österreichische Zeitschrift für Geschichtswissenschaft 130

Otho, King 104

Ottoman Empire 17, 22, 37, 67, 69, 156, 183, 191

Ottoman Imperial Museum, Turkey 152, 156

Our Creative Diversity (UNESCO) 83

overcharged collections 101

Overseas Museum, Portugal 50, 52

Owen, Richard 70, 84 n5

pact, concept of 121

pacte autobiographique 121

Padania 131

Pakeha people 187

Palace Armoury, Malta 152

Palais de la Porte Dorée, Paris 129

Palazzo Carignano 133

Paris: cultural constitution 191

Paris Salon, Au pays de la mer exhibition 98

Parthenon Marbles 92, 154-55, 184

pastoral power $73-79,83,180-81$

patriotic art 92

patrons 96

Paxton, Joseph 102

Payne, Alexander, About Schmidt 135-36

peasant culture 15-16, 39, 41, 43, 44-45, 47, 59, 185

Pei, Ieoh Ming 105, 106

Pentecostal Christians 80, 82
People's Museum, Sofia 44, 153

Petőfi, Sándor 15

Pevsner, Nikolaus 104

philanthropists 96

Philippines 23

Phillips, R.B. 124

photography in museums 111-12

Piano, Renzo 103, 105

Picasso, Pablo, Guernica 93

Piedmont 135

Pietism 75-76

Pigage, Nicolas de 99

pillarization 125

Pitt Rivers Museum, Oxford 71

Pius IX, pope 132

Pointe à Callière, Montreal 125

Poland 152, 188; art and culture 41; art museums 107; culture and nature 40; Government Commission for Religious Affairs and Public Entertainment 107; memorial museums 54-55; national/ transnational intersections 69; post 1918 36; socialist patriotism 45,46

Polish museum in exile 97

political constitution 168, 172-74, 176

politics, and culture $177-78$

Pomian, Krzysztof 74

Pompidou, Georges 105

Popular Front, France 70

portraits 98

Portugal 152, 154, 182; archaeological heritage 42; art museums 97; colonial museums 50, 52; cultural constitution 191; history of civilization 160 ; imperialism 22-23; pastoral power 76

Posse, Hans 103

post-colonialism 5, 6, 34, 50, 51, 52, 56, $57,73,109,171,180,185,186-87$, 190-91

post-structuralism 167

Poussin, Nicolas, Landscape with a Man Killed by a Snake 94

Prado, Spain see Museo Nacionale del Prado, Madrid

Prague Museum 126

prehistoric cultures 186

presentation volumes 99

propaganda 47, 90, 94, 112, 176, 177

Prussia 22

Qingdao 70

Queensland 123

race and racial hierarchies 70-71

'race' museum (proposed), Berlin 39

Rapperswil, Switzerland 97 
Refugio-Museo de la Guerra Civil, Cartagena 129

regional diversity, and imperialism 22 regionalism 14, 20, 57; representations of 25-26

religion(s) 67, 73-79, 83, 193, 196; and state $79-82$

religious conflict 83

religious tolerance 79-82

Renner, Karl 130

repatriation of artefacts $73,81,124$, 154-55, 158, 169, 184-85, 187, 191

representation 182-83; and change

$167-70$; meaning of term 123;

to mobilize $187-88$

research and educational approaches 179, 192

Ricciotti, Rudy 106

Riesenrundgemälde 125

Riga City Museum of Art 40

Rijksmuseum, Amsterdam 105, 127

Rindzevičiūte, Eglé 84 n4

Rivet, Paul 70

Rivière, George Henri 70

Robinson, J.C. 111

Rocard, Michel 128

Roche, Daniel 129

Rogers, Richard 105

Roman Catholics 81

Roman Empire 17, 42, 72, 75, 182, 184

Roman-Germanic Museum, Mainz 27

Romania 152, 180, 182, 189; ethnography museums 45 ; history of civilization 159; memorial museums 54; as new nation state 20; post 1918 36, 37; socialist patriotism 45-46; as stateless nation 23

Romanian National Museum 20

Romanov collection 103

Romany peoples $71,72,83$

Rosenzweig, R. 137

Royal Association for the Promotion of Fine Arts in Scotland 97

Royal Cambrian Society 24

Royal Chamber of Art, Denmark 68 royal collections $68,77,92,103,184$

Royal Institution of South Wales 24

Royal Museum of Central Africa, Tervuren 49-50, 52, 131

Rubens, Peter-Paul 99

Rüsen, Jörn 196

Ruskin, John 84 n5

Russia 69, 183; national flag 160; national/ transnational intersections 69 ; transnationalism 73
Russian Empire 40

Saga manuscripts 68, 100, 158

Salamanca Archives 129

Salazar, António de Oliveira 23, 97

Sámi people 16, 47, 73, 187; see also Sápmi

Samoa 70

Samuel, Raphael, Theatres of Money 137

Sandberg, Willem 109

Santralistanbul 179

Sápmi 73, 153, 157, 188; see also Sámi people

Sarkozy, Nicolas 128

Savoy kings 134

Scandinavia; ethnography museums 44; Norden 2; see also individual nations

Scandinavian Ethnographic Museum, Sweden 27, 28

Schindler Factory, Cracow 54

Schinkel, Karl Friedrich 103, 105, 107, 110

science museums 18, 179, 192

Scotland 120, 152, 154, 188; art societies 95; cultural constitution 195; history of civilization 160; landscape 125; national flag 162

Scott, Katie 111

Second World War 33

Sejima, Kazuyo 106

self-governance 74, 75-78

semiophores 74

Senneh, Lamin 79-80

Seoul 171

Serbia 152, 156-57; art museums 99, 109 ; history of civilization 159 ; modern art 102

Serrano, Andres, Piss Christ 80

Shaw, W.M.K. 156

Shoah see Holocaust

Sighet Memorial Museum, Sighet 54

Skansen, Stockholm 16, 43-44, 189

Sleswig 68

Sloane, Hans 16

Slovak National Museum, Bratislava 45

Slovakia 134, 183; ethnography museums 45

Slovenia 69, 152, 155-56; cultural and ethnic diversity $84 \mathrm{n} 4$; history of civilization 159

Smith, Laurajane 168

Smithsonian, US 179

social, the 76-77

socialist nations, culture and ethnographic approaches 33, 59

socialist patriotism $45-47$ 
'socialist realism' 90

society museums 120

Society of Antiquaries 95

Society of Engineers 179

Society of Nations 93

South Africa 187

South Kensington Museum 78, 102, 104, 110; see also Victoria and Albert Museum South Korea 188

Southwest Africa 70

sovereignty 74-75, 76, 77, 147, 148, 160-61

Soviet empire 67, 178, 183, 186,

189, 193-94

Soviet Union 33, 50, 69, 187; national flag 160

Spain 151, 154, 182; archaeological

heritage 42; art museum settings 105; art museums 90; art ownership 92; Civil War trenches 129; colonialism 49; cultural constitution 191; ethnic multiculturalism 57-58; Historical Memory Act (2007) 129; history museums 129; imperialism 23; modern art 101; museum security 93; national art 100; pastoral power 76; Socialist Party 129

Spanish Civil War 93, 134

'specialist' museums 18

Spirits of Sing exhibition 124

St. Mungo Museum of Religious Life, Glasgow 82

Städelsches Museums-Verein, Frankfurt 19 state: and civil society $8,19,194,196$; and religion 79-82

State Historical and Ethnography Museum of Lithuania 47

state-society schematization $77,81,82$

statehood 23, 24, 25, 34-35, 36, 40, 46, 59, $72,165,183$

stateless nations 13-14, 23-25

statistics, as 'state science' 76

Stedelijk Museum of Modern Art, Amsterdam 105, 109

Stockholm 184

Stockholm Art Association 95

Straw, Jack 81

Stüler, August 105

surpluses 101

Sweden 16, 151, 154, 157, 188; art ownership 92; art societies 95; cultural constitution 190, 191, 194; ethnography museums 43-44; modern art 102; transnationalism 73

Swiss National Museum, Zurich 104, 126, 153

Switzerland 153, 173, 197 n3; art museum settings 104; cultural constitution 190,
197 n3; heritage of Middle Ages 39;

national flag 160

symbolic regimes approach (Elgenius)

$7,146,160-63$

symphony model 8, 190, 192, 193, 194

Széchényi, Count 15

Tallinn State Art Museum 90

Tate Encounter 112

Tate Modern 99, 103

Tate Museum 98, 99, 109, 112

technical museums 17

The Sámi Collection, Norway 153

The Studio 98

Thelen, D. 137

Third Reich 67

Third Worldist approaches 33, 50, 109, 180

Thompson, Grahame 80

Thompson, P. 137

Thracia 46

Tollens, Hendrik 111

Topkapi Palace Museum, Istanbul 38

Torino 133, 134, 135

tourism 33-34, 55, 59, 113, 185

'tradition of the new' 90-91

transnationalism 14, 26-27, 29, 33, 34, 56, $59,78-79,83,124$; national/transnational intersections $67-73$

Transylvania $36,37,46$

travel industry 33-34, 55

Treaty of Westphalia 74

Tropenmuseum, Netherlands 48, 51-52

Trudeau, Pierre 123

tsarist empire 36, 39

Tschudi, Hugo von 96

Turkey 17, 42, 152, 156, 179, 182, 183, 188; cultural constitution 190, 193; Kurdish issue 188; modern art 102; post 1918 37-38

Turkish Cypriots 72, 156

Tuscany, art ownership 92

Tyrol Panorama museum, Innsbruck 125

Tzigara-Samurcas, Alexandru 45

Uffizi Gallery, Florence 92, 93, 151, 155

Ulászlo II, of Hungary 36

Ulster Museum, Belfast 153

UNESCO 83

United Kingdom 134, 183; cultural constitution 195; ethnic multiculturalism 57; see also Great Britain; individual nations

United States 70, 187; creation museums 80; cultural constitution 194; first nations 123; law 173-74 
Universal Exposition (1900) 22

Universal-museum Joanneum, Styria 151, 155

Universal Museums 191

universalist approaches 2, 4, 6, 34, 38-39, 41-42, 44, 51-52, 56, 59, 90-91, 97, 98-101, 106, 155, 158, 159, 168-69, 173, 183, 184, 186, 190, 191-93, 194

University of Berlin 103

University of Bucharest 20, 23

University of Olso 23

USSR 45, 47

Ustasha terror 54

Valéry, Paul 94

van der Rohe, Ludwig Mies 103

van Eyck, Jan 99

Van Gogh Museum, Amsterdam 105

Van Gogh, Theo 127

varietate concordia 186

Vasa, Swedish naval ship 53

Vatican 129, 132

Velasquez, Diego 100

Venturi, Robert 105

Verba, S. 174

Verfassungsgeschichte 6, 120, 123

Vergangenheitsbewältigung 187, 196

Verhagen, Maxime 127-28

Versailles, château de 99, 103

Victoria and Albert Museum 71, 102, 110-11, 184; see also South

Kensington Museum

Victoria, Queen 102

Victoria, state of 123

Vienna 104, 155, 183, 184; cultural constitution 191; military museum 130

Vienna Congress (1845) 134

Vietnam 50

Viking (Ship) Museum, Oslo 43

von Humboldt, Friedrich Wilhelm 103 von Klenze, Leo 103, 104

Vytautas Great Museum of Culture, Lithuania 100

Vytautas the Great 100

Waagen, Gustav Friedrich 99, 107

Walachia 20

Waldheim, Kurt 130

Wales 120, 153, 154; 'blue books' 24; cultural constitution 190, 195; regionalism 28-29; as stateless nation 24-25; Welsh language 24

Waterfield, Giles 100

Weber, Max 82

Weizenberg, August 100

Welsh language 24

West Africa 70

West Germany 48

Western civilization 2

Western Europe 120; see also individual nations

Wilhelm I 19, 20

Winckelmann, Johann Joachim 112

Wingfield, Chris 84 n5

Wittlin, Alma S. 113

women, representatives of the nation 127

World Commission on Culture and Development 83

World Exhibition, Sevilla (1992) 50

worldview, framing 180-82

Wundt, Wilhelm 108

Yad Vashem, Jerusalem 54

Young Turks 17

Yugoslavia 156, 157, 180, 189; art and culture 41; colonial museums 50; cultural constitution 194-95; heritage of Middle Ages 39; modern art 102; post 191837 